\title{
Application of Bionic Methods, Traditional Technologies and Contemporary Trends into the Design of An Innovative Concept of Food Preparation Appliance
}

\author{
Violeta Vidoevska*
}

Faculty of Mechanical Engineering, Industrial Design, Ss. "Cyril and Methodius University" of Skopje, Skopje, Republic of Macedonia

\begin{abstract}
Citation: Vidoevska V. [Application of Bionic Methods, Traditional Technologies and Contemporary Trends into the Design of An Innovative Concept of Food Preparation Appliance]. SEE J Archit Des. 2018 May 11; 10034. [MSC] Macedonian

. 2018.10034

Keywords: Solar energy; Technology; Bionic design;

"Correspondence: Violeta Vidoevska. Faculty of Mechanical Engineering, Industrial Design, Ss. "Cyril and Methodius University" of Skopje, Skopje, Republic o

Received: 06-Apr-2018; Revised: 08-May-2018; Accepted: 10-May-2018; Published: 11-May-2018

Copyright: ( 2018 Violeta Vidoevska. This is an openaccess article distributed under the terms of the Creative Commons Attribution License, which permits unrestricted use, distribution, and reproduction in any medium provided the original author and source are credited. Competing Interests: The author has declared that no competing interests exis
\end{abstract}

\begin{abstract}
This master thesis represents an effort to design portable food preparation appliance that functions on a solar energy parameter. The leading idea for the start of this entire concept was the amazing potential and possibilities that this technology offers, as well as the opportunity to create product that will be fully independent of electrical network, while at same time shall remain appealing, functional and ecological.

By researching the existing appliances on the market, basic constructions, types and characteristics, an analysis was performed on their advantages and disadvantages. The analysis continued by polling possible users, where their requirements through the House of Quality were transformed into engineering specifications.

The search of form that would be most suitable in the context of the given requirements was based on the principles of bionics, where with the application of bionic methodology a comprehensive research was conducted in the context of structures, processes, functions and forms from the nature, to the end of better comprehension, connection and finding the most suitable solution among them. The bionic methodology was conducted in "from design problem to bionic solution" approach. Several concept solutions were suggested, one of them was selected by evaluation, after which it was elaborated in detail. The detailed elaboration included design of 3D CAD model, technical drawings, detailed description of components and materials, visualization and presentation of results.
\end{abstract}


Машински факултет Скопје

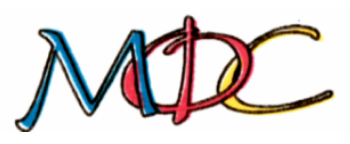

Постдипломски студии - Индустриски дизајн и маркетинг

Видоевска Виолета

\section{Примена на бионички методи, традиционални технологии и современи трендови во дизајн на иновативен концепт на уред за подготовка на храна}

Магистерски труд

Скопје, 2014 
Ментор:

Членови на комисијата:

Дата на одбрана:

Дата на промоција:
Проф. д-р Софија Сидоренко

Машински факултет - Скопје

Проф. д-р Софија Сидоренко

Машински факултет - Скопје

Проф. д-р Татјана Кандикјан

Машински факултет - Скопје

Проф. д-р Ристо Ташевски

Машински факултет - Скопје 
Кандидат:

Видоевска Виолета

Тема:

Примена на бионички методи, традиционални технологии и современи трендови во дизајн на иновативен концепт на уред за подготовка на храна

\section{Апстракт:}

Во овој магистерски труд направен е обид за дизајнирање на пренослив уред за подготовка на храна кој функционира на принципот на соларна енергија. Водечка идеја за започнување на целиот овој концепт претставуваше неверојатниот потенцијал и можности кои го нуди оваа технологија и можноста за креирање на производ кој ќе биде целосно независен од електричната мрежа, а истовремено привлечен, допадлив, функционален и еколошки.

Со истражување на постоечките уреди на пазарот, основните конструкции, видови и карактеристики се направи анализа на нивните предности и недостатоци. Анализата продолжи со анкетирање на можните корисници, каде нивните барања преку куќата на квалитет беа преточени во инженерски спецификации.

Потрагата по форма која би била најсоодветна на поставените барања се темелеше на принципите на биониката каде со примена на бионичка методлогија се направи опсежно истражување на структури, процеси, функции и форми од природата со цел подобро разбирање, поврзување и изнаоѓање на најсоодветно решение меѓу нив. Бионичката методологија се одвиваше во правец „од дизајн проблем до бионичко решение“. Предложени беа неколку концепт решенија, од кои преку процесот на евалуација се одбра еден, кој потоа беше детално разработен. Деталната разработка опфати изработка на CAD модел, технички цртежи, детален опис на компоненти и материјали, визуелизација и презентација на резултатите.

Клучни зборови: соларна енергија, технологија, бионички дизајн, подготовка на храна 
Candidate:

Vidoevska Violeta

Thesis:

\title{
Application of bionic methods, traditional technologies and contemporary trends into the design of an innovative concept of food preparation appliance
}

\begin{abstract}
:
This master thesis represents an effort to design portable food preparation appliance that functions on a solar energy parameter. The leading idea for the start of this entire concept was the amazing potential and possibilities that this technology offers, as well as the opportunity to create product that will be fully independent of electrical network, while at same time shall remain appealing, functional and ecological.
\end{abstract}

By researching the existing appliances on the market, basic constructions, types and characteristics, an analysis was performed on their advantages and disadvantages. The analysis continued by polling possible users, where their requirements through the House of Quality were transformed into engineering specifications.

The search of form that would be most suitable in the context of the given requirements was based on the principles of bionics, where with the use of bionic methodology a comprehensive research was conducted in the context of structures, processes, functions and forms from the nature, to the end of better comprehension, connection and finding the most suitable solution among them. The bionic methodology was conducted in "from design problem to bionic solution" manner. Several concept solutions were suggested, of which one was chosen by evaluation, after which it was examined in detail. The detailed examination included construction of CAD model, technical drawings, detailed description of components and materials, visualization and presentation of results.

Key words: solar energy, technology, bionic design, food preparation 


\section{Содржина}

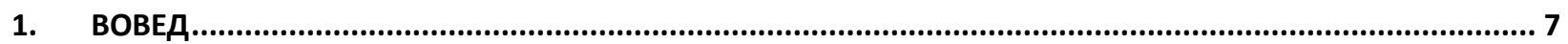

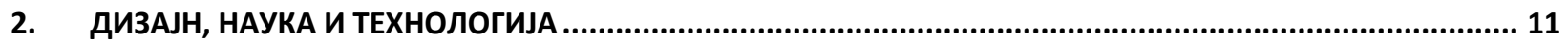

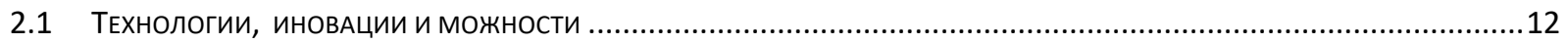

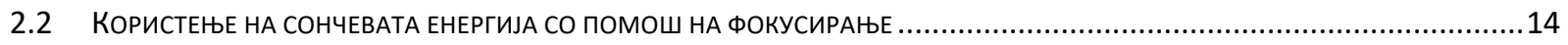

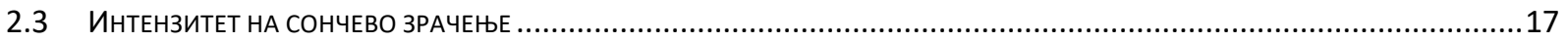

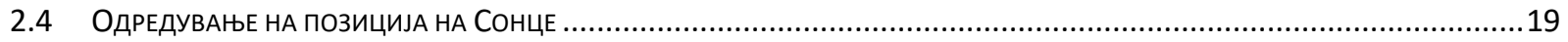

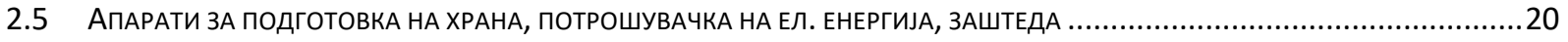

3. СОЛАРНА ЕНЕРГИЈА ВО ПРОЦЕСОТ НА ПОДГОТОВКА НА ХРАНА.................................................. 22

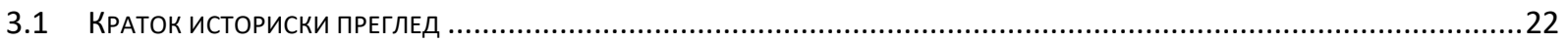

3.2 ОСНОВНИ КАРАКТЕРИСТИКИ, ВИДОВИ И КОНСТРУКЦИИ НА СОЛАРЕН ШПОРЕТ.................................................23

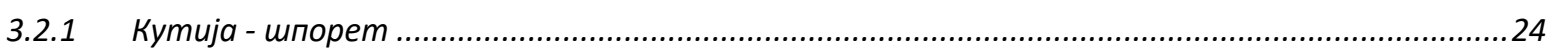

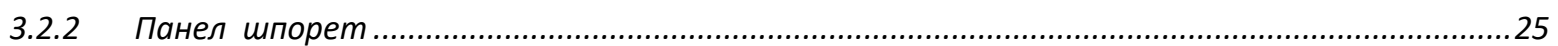

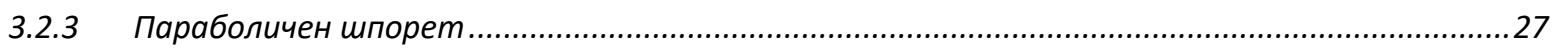

3.3 ПРЕДНОСТИ И НЕДОСТАТОЦИ НА ОСНОВНИТЕ ВИДОВИ НА СОЛАРЕН ШПОРЕТ .....................................................28

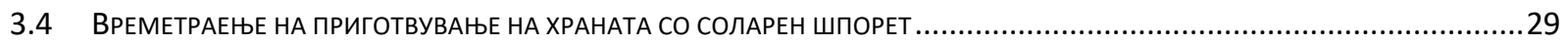

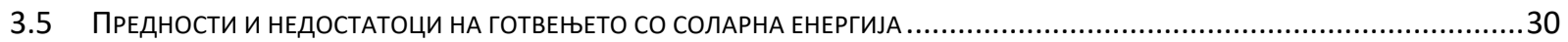

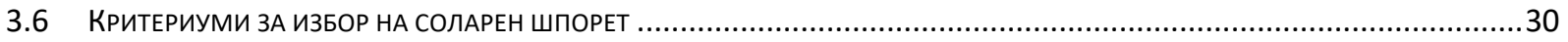

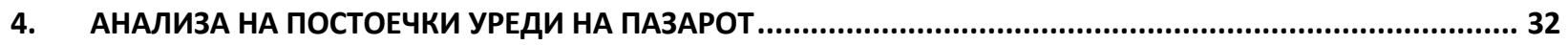

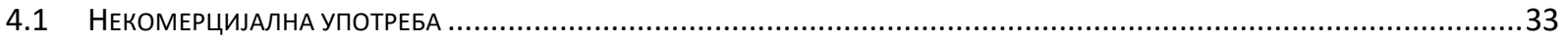

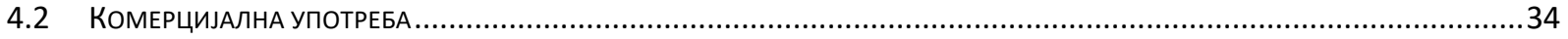

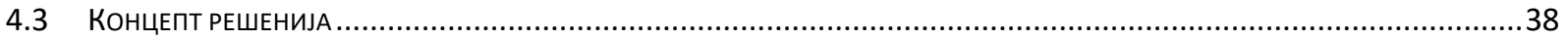

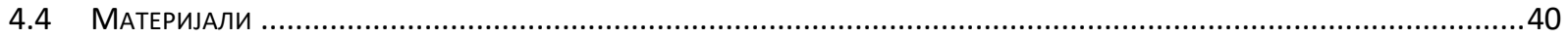

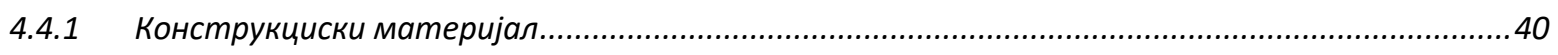

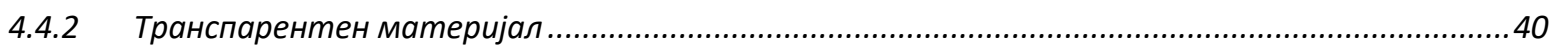

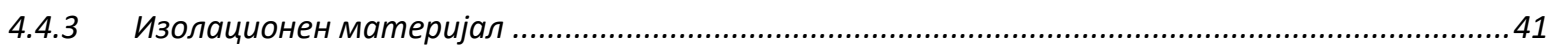

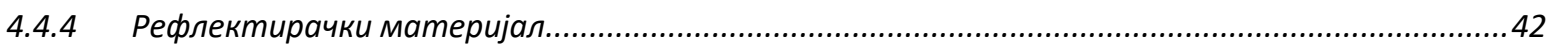

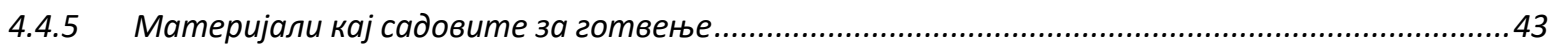

5. ДЕФИНИРАЊЕ НА КАРАКТЕРИСТИКИТЕ НА НОВИОТ КОНЦЕПТ ...................................................... 44

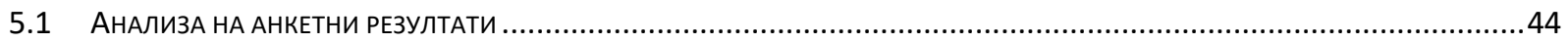

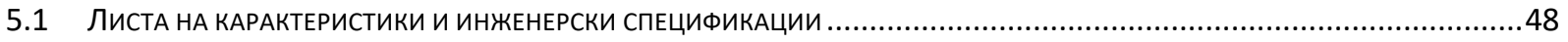

Видоевска Виолета МАГИСТЕРСКИ ТРУД 
6. ПРИМЕНА НА БИОНИЧКА МЕТОДОЛОГИЈА ЗА ГЕНЕРИРАњЕ НА КОНЦЕПТИ ..................................... 51

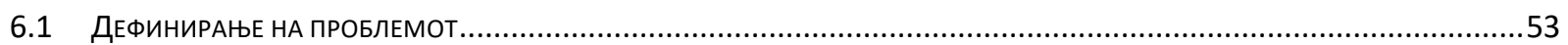

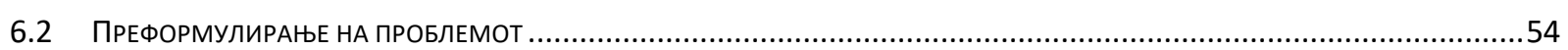

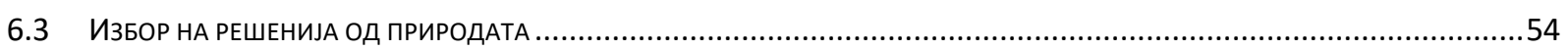

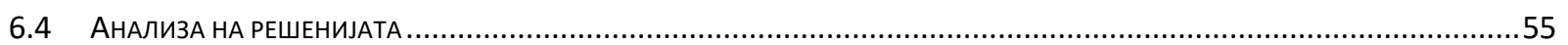

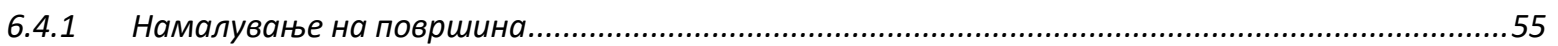

6.4.2 Комплексни структури кои фокусираат рефллектирана светлина........................................57

6.4.3 Структури кои го менуваат обликот со значителна промена на својата големина .............58

6.4.4 Компактен облик кај растенијата ……..............................................................................60

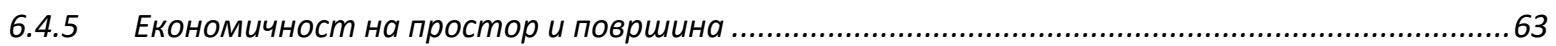

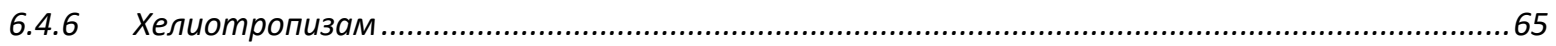

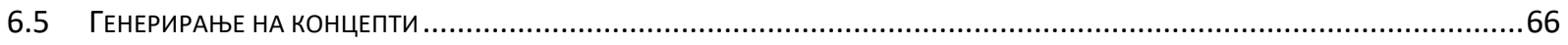

6.6 ИзБОР НА НАЈСООДВЕТЕН КОНЦЕПт ...................................................................................................

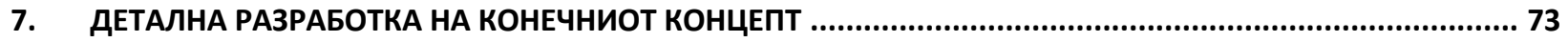

7.1 ОДРЕДУВАҢЕ НА ФОКУС КАЈ ПАРАБОЛА И ПРИМЕНА НА ПОДАТОЦИТЕ .............................................................73

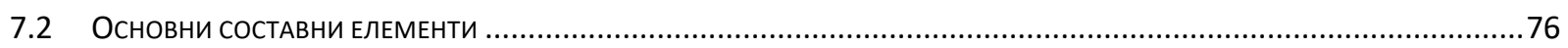

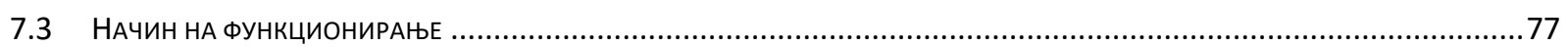

7.4 ПРИДВИЖУВАњЕ И РЕГУЛИРАњЕ НА АГОЛОТ НА РЕФЛЕКТИРАЧКАТА ПАРАБОЛА.......................................................77

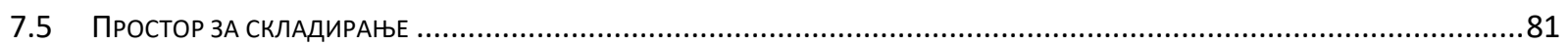

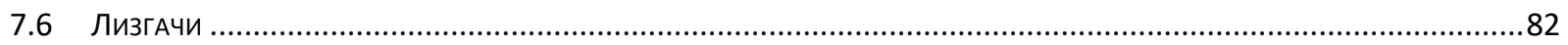

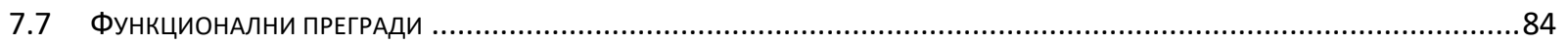

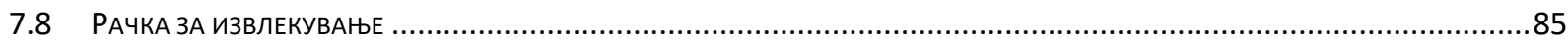

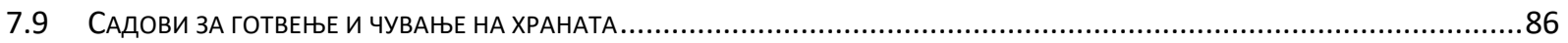

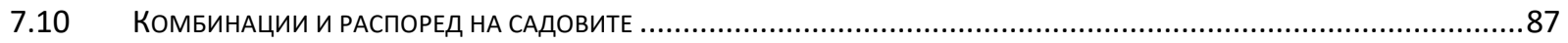

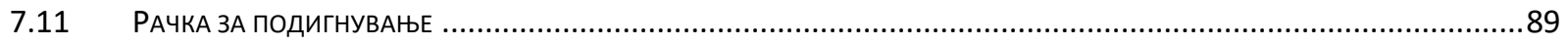

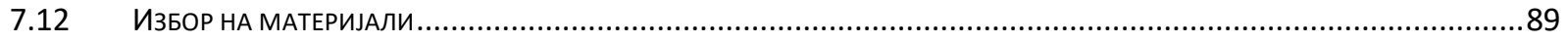

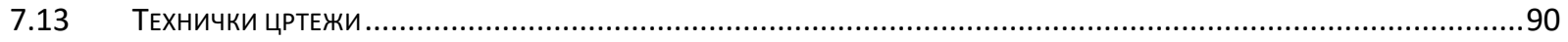

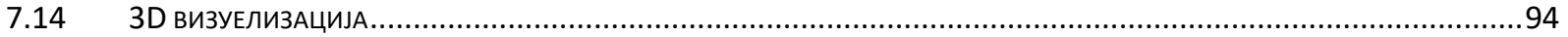

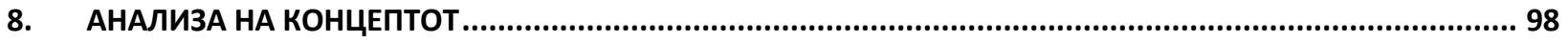

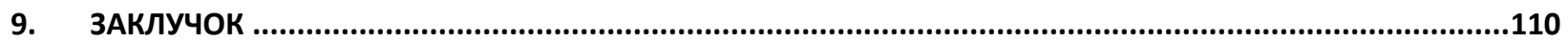

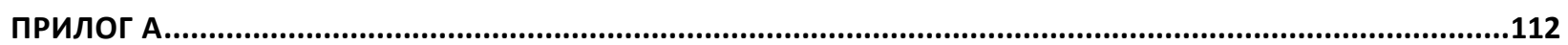

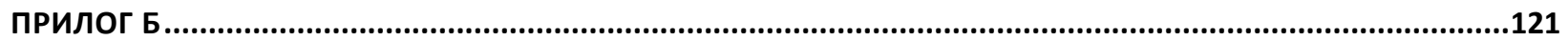

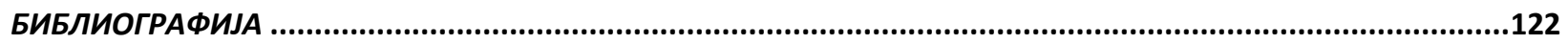

Видоевска Виолета $\quad$ МАГИСТЕРСКИ ТРУД 6 


\section{1. Вовед}

Историјата на човештвото е сведоштво за постојаното зголемување на потребите и барањата од животната средина. Особено од индустриската револуција наваму, природните богатства и ресурси на Земјата се искористуваат со континуирано растечко темпо кое резултира со огромни штети врз животната средина. Брзиот развој на науката и технологијата доведе до верување дека сите проблеми можат да бидат решени со примена на високата технологија, што ја наруши хармонијата со природата. Кризата од глобалното затоплување, која не́ демне, веќе не́ натера да размислуваме потрезвено, да се обидеме да воспоставиме една посериозна врска помеѓу природата и технологијата.

Индустриските дизајнери, во соработка со експерти од сите области на науката и технологијата, се должни да дадат придонес кон подигнување на свеста за последиците од неразумното трошење на енергијата и ресурсите. Во последниве неколку децении евидентни се нивните обиди да креираат производи кои не ја загадуваат околината и кои обезбедуваат економично искористување на енергијата. Бројни дизајнерски решенија применуваат најнови сознанија и препораки од областа на екологијата, како и најнови технолошки иновации со кои се унапредува заштитата на човековата околина.

Припремата на храна е активност која се врши секојдневно заради задоволување на основните животни потреби на луѓето. За таа цел се троши голема количина енергија. Голем број дизајнери, инженери и технолози работат на темата дизајн на уреди за подготовка на храна кои ќе овозможат добивање на здрава храна и ќе обезбедат поголема заштеда на енергија. Употребата на соларната енергија за термичка обработка на храната во однос на користењето на традиционалните методи претставува остварлива алтернатива. Веќе се во употреба уреди кои ја користат пасивно соларната енергија, но овој начин сеуште не може во целост да го замени традиционалниот начин на готвење. Примената на една ваква технологија може да даде голем придонес за ублажување на проблемите со загадувањето на природата, а има и свои економски и социјални бенефити. Токму затоа заслужува да се развива и да биде имплементирана на поинаков, иновативен начин. Тоа беше и главен поттик и инспирација за оформување на темата за овој магистерски труд. Главна цел е да се даде придонес во областа на индустрискиот дизајн на производи кои се 
грижат за заштитата на човековата околина преку концепт на уред за подготовка на храна кој ќе користи технолошки решенија за заштеда на енергија. При тоа ќе бидат применети современи методи на дизајнирање, пред се́ од областа на биониката.

Основната цел на овој магистерски труд е да се даде придонес кон дизајнот на нови производи кои се грижат за заштитата на човековата околина. Конкретна цел ќе биде да се истражат современите трендови во областа на индустрискиот дизајн и современите технолошки достигнувања кои ќе бидат теоретска подлога, неопходна за креирање на иновативно концепт решение на еколошки уред за подготовка на храна.

Се очекува да биде понуден дизајн на уред за подготовка на храна кој ќе биде адаптибилен, ќе се користи на отворен простор и ќе треба да овозможи заштеда на енергија. На тој начин, неговата примена во секојдневниот живот би значела голем придонес кон заштитата на човековата околина.

Во оваа магистерска работа ќе бидат применети современи методи кои се применуваат во индустрискиот дизајн. Потрагата по форма која би била најсоодветна на поставените дизајнерски барања би се темелела на принципите на биониката. Бионика е интердисциплинарна наука која има за цел да понуди методи со кои преку потрага во природата би се обезбедиле решенија за инженерски и дизајнерски проблеми во различни области и гранки на науката и техниката, вклучувајќи го и индустрискиот дизајн. Со примена на бионичкиот метод одгоре-надолу би се трагало кон решенија во природата со цел од нив да се извлечат суштинските карактеристики кои би биле одговор на дизајнерската задача. Истражувањето во рамките на овој магистерски труд би требало да се одвива во следните фази:

I. Теоретска анализа која ќе се состои од проучување на расположивата литература и научни трудови од областа на биониката, потрага по современи технолошки решенија за примена на алтернативните извори на енергија, проучување на традиционални уреди за подготовка на храна и современи концепт решенија на уреди кои функционираат на алтернативни извори на енергија итн. 
II. Прецизно дефинирање на дизајнерскиот проблем, истражување на пазарот и дефинирање на потребата од ваков вид производ. Во оваа фаза ќе биде неопходно да се изврши анкетирање на потрошувачите со цел да се утврдат нивните ставови околу прифаќањето на ваков вид производ и што тие би очекувале од него. Анализата треба да биде финализирана со примена на куќа на квалитет, при што барањата на потрошувачите ќе бидат преточени во конкретни инженерски барања.

III. Во третата фаза треба да биде извршено реформулирање на претходно изнесените барања преку дефинирање на соодветни функции од биологијата.

IV. Во следната фаза, според извршената реформулација, треба да биде спроведено истражување на појави, процеси и структури од природата со цел да се најде соодветен биолошки модел, како урнек кој ќе биде инспирација за решавање на дизајнерскиот проблем. На овој начин можат да бидат извлечени еден или повеќе урнеци - биолошки модели. Преку нивна анализа треба да се дојде до избор на оној бионички модел што ќе биде најсоодветен урнек за решавање на дизајнерскиот проблем.

V. Во следната фаза, следејќи го бионичкиот модел и претходно утврдените начела, треба да бидат генерирани концепт решенија за дизајнерскиот проблем, од кои со соодветна методологија за оценување ќе биде избрано најсоодветното за понатамошна разработка.

VI. Последната фаза ќе ја опфати деталната разработка на концептот - изработка на CAD модел, технички цртежи, детален опис на компоненти и материјали, визуелизација и презентација на резултатите.

Се очекува концептот на уред за подготовка на храна, кој ќе биде краен резултат на целокупното истражување во овој магистерски труд, да биде придонес кон изнаоѓањето на иновативни решенија за подобрување на условите за живот на луѓето во секојдневието, а да при тоа не се загрози животната средина. Со систематизирање на знаењата за постоечките иновативни технолошки достигнувања во областа на обновливи извори на енергија, кои се во голем подем, се очекува да се дојде до иновативен концепт на производ кој ќе може во целост да ги задоволи барањата на потрошувачите, но и на животната 
средина. Производот треба да биде целосно независен од електричната мрежа, со дизајн кој треба да биде привлечен, допадлив, функционален и еколошки.

Се очекува истражувањата на принципи, форми и структури од природата и примената на воспоставените методи на биониката, особено принципот „од дизајн проблем до бионичко решение“, да дадат успешно и иновативно решение на поставениот дизајнерски проблем. Ова истражување треба да претставува и поттик за изнаоѓање нови, иновативни решенија, каде примарна цел ќе биде искористувањето на енергијата од обновливите извори и урнек за останатите индустриски дизајнери како да постапуваат во процесот на дизајнирање во рамките на нивните дизајнерски задачи, поточно, како да трагаат кон решенија кои ќе придонесат кон заштитата на човековата околина. 


\section{2. Дизајн, наука и технологија}

Познавањето на технологијата и природните науки играат важна улога во процесот на дизајнирање. Процесот на дизајнирање се рефлектира преку односот на уметноста како дел од креативниот процес и науката која се развива во контекст на стандарди, регулација, современи можности на материјали и инженерство ${ }^{1}$. Современиот дизајнерски концепт мора да има интердисциплинарност со сродните научни достигнувања. Нивната имплементација се разбира треба да биде во форма прилагодена на дизајнерските потреби, но да даде инспирација и овозможи развој на нови иновативни решенија.

Досега човекот и неговите потреби се наоѓаa во центарот на дизајнерските проекции, но со глобалниот тренд на менување на навиките на потрошувачите, како примарни фактори се јавуваат ${ }^{2}$ технологијата, еколошкиот момент и едноставноста, кои мора да поминат низ филтерот на економичност, односно рационалност на своето постоење и оправдување. Промените во технологијата поврзани со новите материјали, еко одржливите концепти, заштедата на енергија и природата како перфектен модел за инспирација им отвараат нови можности на дизајнерите за решавање на голем број проблеми.

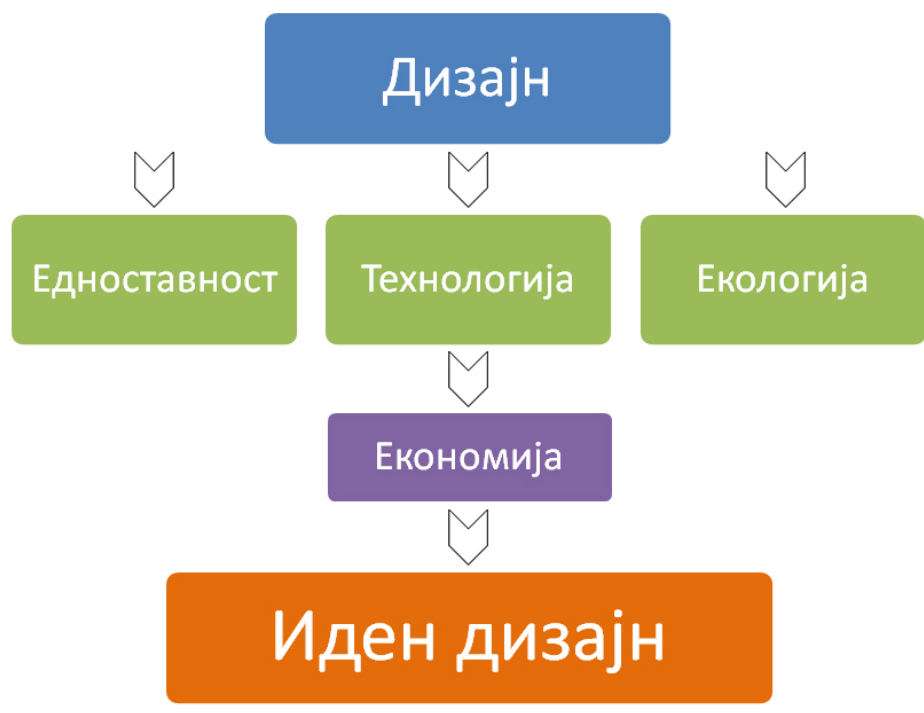

Слика 2.1 Фактори во процесот на дизајнирање (футуристички дизајн)

\footnotetext{
${ }^{1}$ Петар Намичев, Влијанијата на економската криза врз современиот дизајн, 2012
}

2 Петар Намичев, Влијанијата на економската криза врз современиот дизајн, 2012 
За потребите на дизајн процесот во овој магистерски труд, ќе бидат разгледени некои основни физички закони како и веќе усвоени принципи и постоечки соларни технологии потребни за понатамошен развој и разбирање на предложените дизајнерски концепт решенија.

\section{1 Технологии, иновации и можности}

Ако треба да замислиме идеален извор на енергија, тоа би можело да се фотоволтаичните ќелии, уште познати и како соларни ќелии. Тие ја конвертираат светлината од сончевото зрачење директно во највредната форма на енергија, електричната енергија. Првичните трошоци за нивна имплментација биле премногу големи, но со понатамошните истражувачки студии и унапредувања тие се видно намалени, за денес да станат многу подостапни. Брзиот технолошки развој и масовното производство ветува дека во блиска иднина ќе станат конкурентни на конвенционалната електрична енергија добиена од мрежа.

Од еколошка гледна точка тие се чист извор на енергија кој не произведува никакви штетни гасови и не е опасен за луѓето и планетата. Келиите најчесто се направени од силицум, вториот најзастапен елемент на Земјата, за кого можеме да кажеме дека претставува непресушна суровина.

Научниците постојано развиваат се́ подобри и поефикасни ќелии од органски материјали, од нови егзотични легури, со квантни точки, нано-жици, како и тенкослојни, речиси прозирни соларни ќелии кои можат да се монтираат на фасадите на објектите или во самите градежни материјали и да произведуваат електрична енергија.
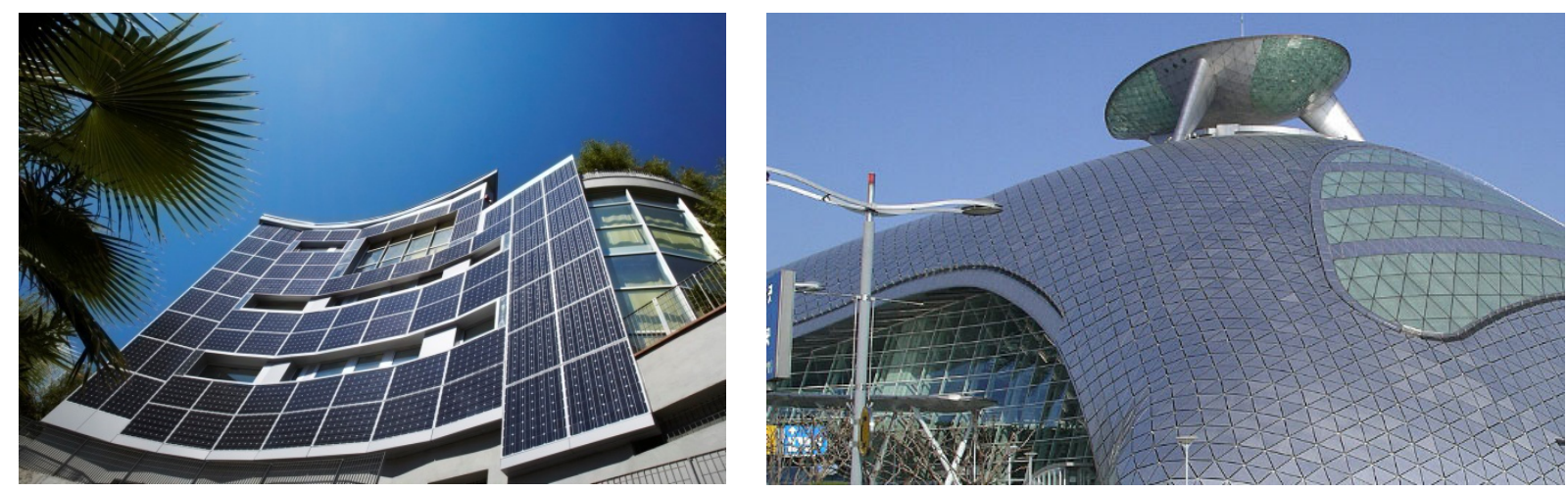

Слика 2.2 Користење на фотоволтаични панели во архитектурата. Директна интеграција на објекти 


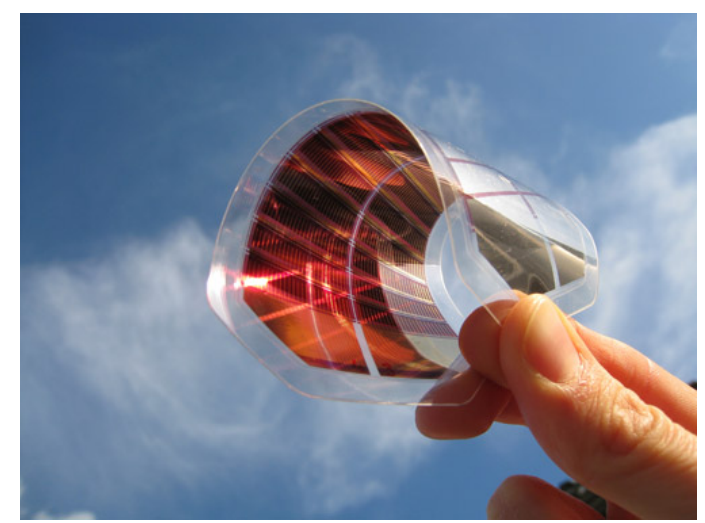

Слика 2.3 Флексибилни фотоволтаични ќелии

Имплементацијата на соларни ќелии кај преносливите уреди е веќе добро позната. Тие може да го напојуваат било кој тип на електрична опрема, како мобилни телефони, таблети, GPS уреди за навигација, аудио плеери, ТВ приемници, компјутери, но и многу повеќе.

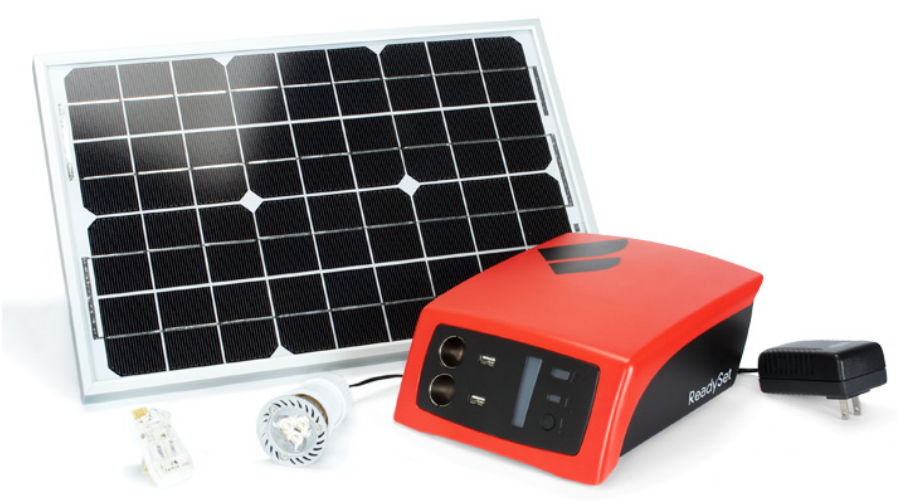

Слика 2.4 Пренослив соларен полнач ReadySet Solar Kit ${ }^{3}$

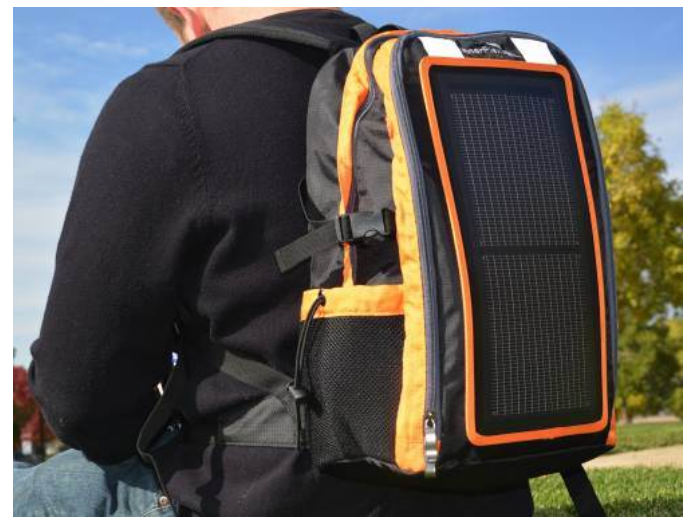

Слика 2.5 Соларен ранец EnerPlex Packr ${ }^{4}$

Француската компанија SunPartner Group 5 има развиено технологија под името $\mathrm{Wysips}^{6}$ која како транспарентен панел може да биде имплементирана на разни површини. Со изложување на извор на светлина, без разлика дали е природен или вештачки, панелот произведува електрична енергија која се користи за полнење на батериите на уредот. Креаторите веруваат дека со оваа технологија секоја површина можат да ја претворат во извор на енергија.

\footnotetext{
${ }^{3} \mathrm{http}: / /$ www.fenixintl.com/product/readyset-solar-kit/

${ }^{4} \mathrm{http}$ ///www.goenerplex.com/products/all-products/packr

${ }^{5}$ http://sunpartnertechnologies.com/

${ }^{6} \mathrm{http}: / /$ sunpartnertechnologies.com/sunpartner-group/expertise/energie-innovante/
} 


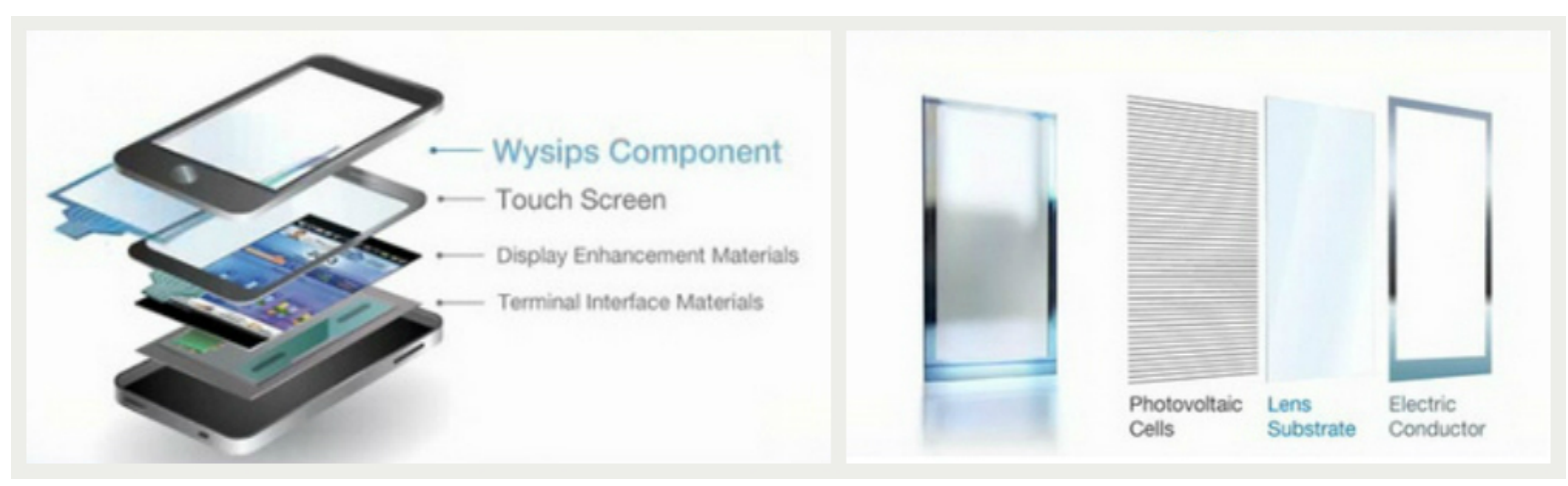

Слика 2.6 Wysips панел вграден на мобилен телефон

Но, технологијата оди далеку понатаму од напојување на светилки и мобилни уреди. Употребата на соларната енергија во транспортниот сектор е во континуиран напредок, особено кај електричните автомобили кои полека стануваат конкурентни на возилата со погон на бензин и дизел. Успешни обиди веќе се направени и во авионската индустрија. Solar Impulse ${ }^{7}$ е првиот авион кој може да лета без гориво, само на соларен погон, и тоа и во текот на денот и во текот на ноќта. Иако сме далеку од комерцијални соларни летови, сепак, ова е показател за неверојатниот потенцијал на оваа технологијата.

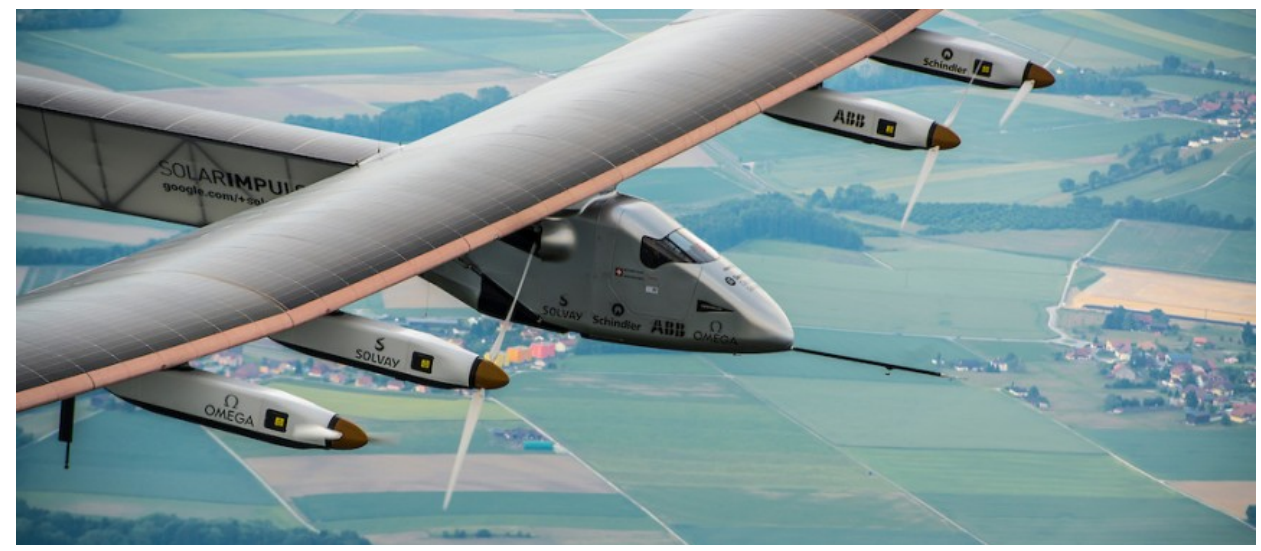

Слика 2.7 Solar Impulse, авион на соларен погон

\section{2 Користење на сончевата енергија со помош на фокусирање}

Сончевата енергија која доспева на Земјата претставува електромагнетно зрачење кое може да се претвори во други форми на енергија: топлинска, хемиска, механичка, електрична. Претворањето на сончевата енергија во топлина е едноставен физички процес кој се постигнува со концентрирање на сончевото зрачење преку разни оптички уреди.

\footnotetext{
${ }^{7} \mathrm{http}: / /$ www.solarimpulse.com
} 
Оптичките уреди можат да се поделат во две групи, и тоа: огледала и леќи. Огледалата можат да бидат рамни или да имаат закривена површина. Закривената површина може да биде во облик на: сфера, елипса, парабола и цилиндрично или параболично корито ${ }^{8}$

Светлинските зраци кои паѓаат на рамно огледало се одбиваат од него по одреден закон кој гласи:

Светлинскиот зрак кој паѓа на рамно огледало се одбива така што аголот на паѓање а е еднаков на аголот на одбивање $\beta$. Упадниот зрак, аголот на одбивање и нормалата се наоѓаат на иста рамнина.

Законот за одбивање на светлината кај рамните огледала важи и за сферните, со таа разлика што по одбивањето зраците се насочуваат кон една точка наречена фокус.

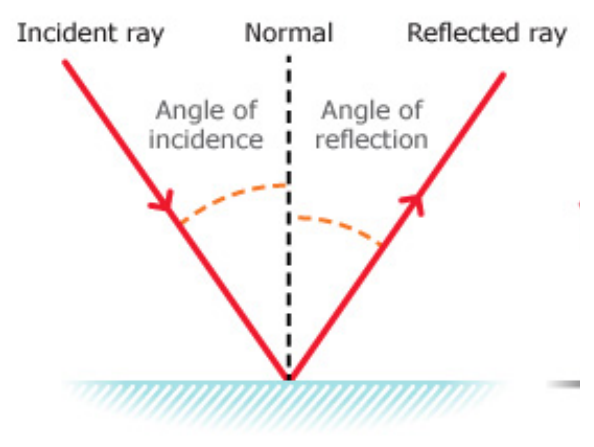

Слика 2.8 Рефлексија од рамно огедало

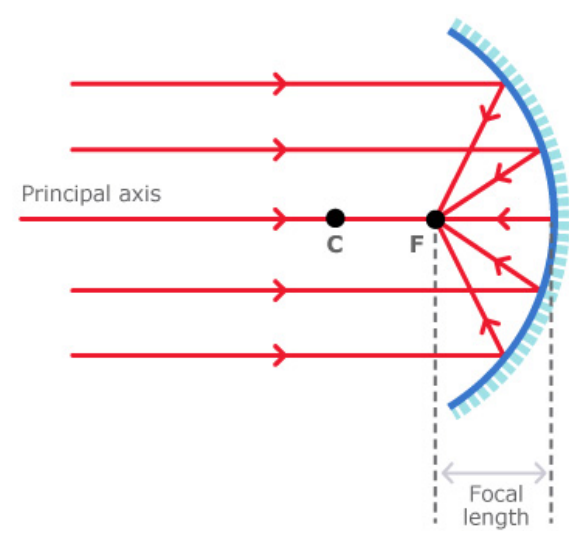

Слика 2.9 Рефлексија од конаквно огледало

Со концентрирање на сончевото зрачење се постигнуваат високи темератури, но само при диркетна изложеност, односно насоченост кон Сонцето. Концентрирањето може да се постигне со соодветно поставување на рамни или сферни огледала прикажани на Слика 2.10 и Слика 2.11.

\footnotetext{
${ }^{8}$ Славе Арменски, Сончева енергија - термичка трансформација, 2012 
a)

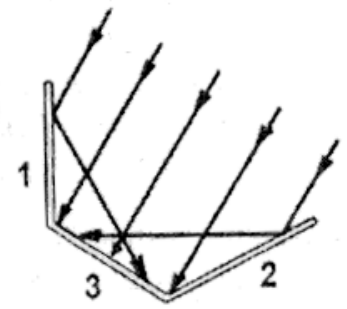

b)

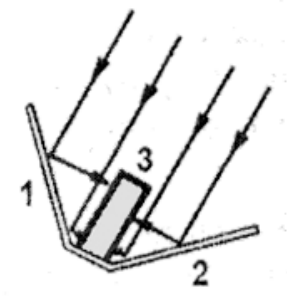

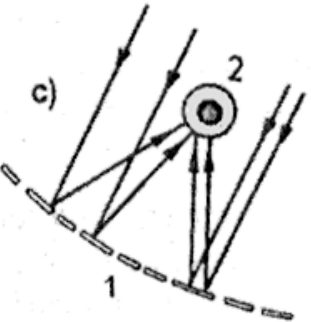

Слика 2.109 Концентрирање на сончевите зраци со рамни огледала

a) рамните огледала 1 и 2 ги концентрираат сончевите зраци на една рамна плоча 3 , која се загрева до висока температура;

b) огледалата 1 и и 2 ги концентрираат сончевите зраци на цилиндрична површина 3, која се загрева до висока температура;

c) систем со повеќе огледала 1 кои ја концентрираат сончевата светлина на една цевка 2.
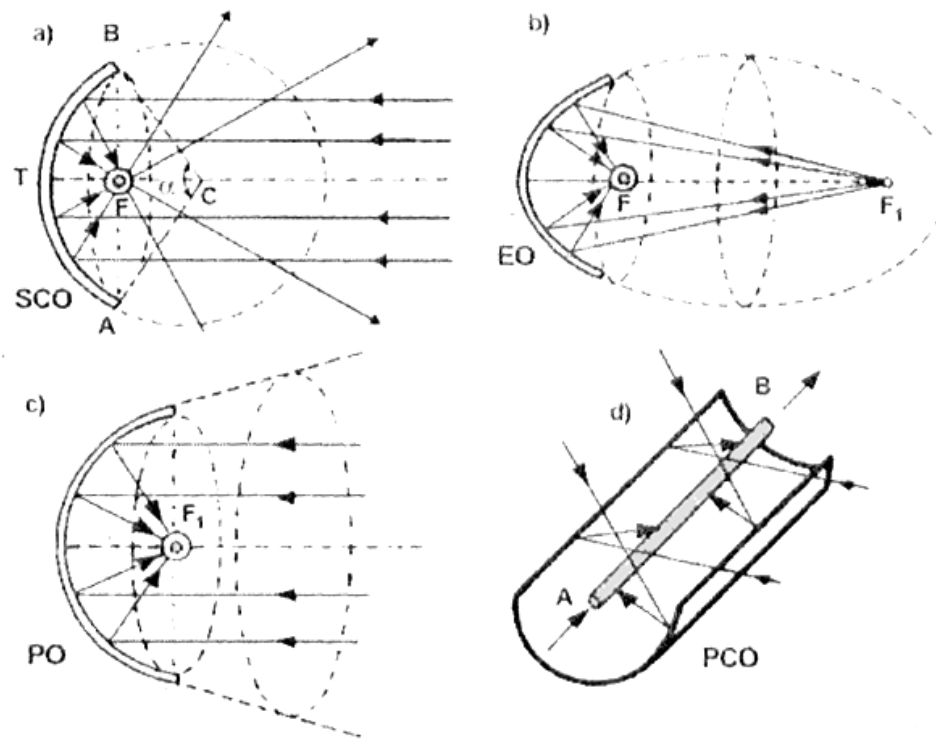

Слика $2.11^{10}$ Концентрирање на сончевите зраци со огледала со закривени површини
a) сферно конкавно огледало
b) елипсовидно огледало
c) параболично огледало
d) параболично огледало во вид на корито

\footnotetext{
${ }^{9}$ Славе Арменски, Сончева енергија - термичка трансформација, 2012
}

${ }^{10}$ Славе Арменски, Сончева енергија - термичка трансформација, 2012 
Фокусирањето на сончевите зраци може да се користи за различни цели, меѓу кои во топлите краишта за приготвување на храна и загревање на течности до високи температури.

\section{3 Интензитет на сончево зрачење}

Интензитетот на сончевото зрачење на површината на Земјата е променлива големина која зависи од повеќе фактори, како што $\mathrm{ce}^{11}$ : правецот на простирање на сончевите зраци, годишното време, траењето на сончевата радијација, аголот на сончевите зраци, ориентацијата на површината на која паѓаат сончевите зраци и метеролошките услови.

Во предели со помали географски ширини (поблиску до екваторот) условите за користење на енергијата од сончевото зрачење се поповолни, додека во поладните северни предели условите се понеповолни. Старите Грци го поделиле светот на тропски, умерени и поларни зони, но всушност постојат голем број на климатски региони и безброј микроклими. Дизајнерите мора најдобро да ги употребат достапните објавени податоци и да се приспособат на различностите за да може дизајнерски успешно да одговорат.

Територијата на Р. Македонија се простира меѓу $41^{\circ}$ и $42^{\circ}$ географска ширина и според истражувањата на експертите има одлични географски и климатски услови за искористување на сончевата енергија. Карактеристиките на сончевото зрачење укажуваат дека интензитетот на сончевото зрачење во нашата земја е поволен за добивање на енергија и тоа максимално во западна Македонија - Охрид, каде што достигнува 1590 $\mathrm{kWh} / \mathrm{m}^{2}$. Просечниот број на сончеви часови во Македонија, во текот на 12 месеци, земајќ́ го опсегот на мерења од 2001 година до 2009 година, на годишно ниво изнесува 2199,9 сончеви часови (Табела 2.1) $)^{12}$.

\footnotetext{
${ }^{11}$ Славе Арменски, Сончева енергија - термичка трансформација, 2012
}

12 Славе Арменски, Сончева енергија - термичка трансформација, 2012 


\begin{tabular}{|c|c|c|c|c|c|c|c|}
\hline Месец/Год. & 2001 & 2002 & 2003 & 2004 & 2005 & 2009 & Просек \\
\hline јануари & 41,0 & 62,3 & 64,7 & 70,6 & 112,4 & 54,1 & 67,5 \\
\hline февруари & 139,0 & 142,1 & 127,7 & 128,9 & 101,7 & 115 & 125,7 \\
\hline март & 154,8 & 155,2 & 235,0 & 180,1 & 165,8 & 140,9 & 172,0 \\
\hline април & 175,9 & 162,4 & 159,7 & 152,2 & 219,7 & 190,1 & 176,7 \\
\hline мај & 229,5 & 225,5 & 280,4 & 241,8 & 240,0 & 265,2 & 247,1 \\
\hline јуни & 334,2 & 306,2 & 322,6 & 264,5 & 299,7 & 269,3 & 299,4 \\
\hline јули & 333,0 & 282,2 & 356,4 & 314,1 & 292,7 & 354,9 & 322,2 \\
\hline август & 312,2 & 240,0 & 318,9 & 295,9 & 252,9 & 289,9 & 285,0 \\
\hline септември & 247,3 & 178,2 & 210,3 & 227,6 & 170,5 & 195,6 & 204,9 \\
\hline октомври & 221,2 & 153,5 & 142,4 & 157,3 & 168,9 & 131,1 & 162,4 \\
\hline ноември & 117,9 & 78,1 & 53,7 & 100,7 & 93,9 & 128,6 & 95,5 \\
\hline \multirow[t]{2}{*}{ декември } & 33,4 & 25,1 & 59,0 & 30,8 & 61,8 & 38,9 & 41,5 \\
\hline & 2339,4 & 2010,8 & 2330,1 & 1900 & 1840,6 & 2042,5 & 2199,9 \\
\hline
\end{tabular}

Табела 2.1 Број на сончеви часови измерени од метеролошката станица „Зајчев Рид“ Скопје

Оптималниот агол на поставеност на еден колектор во Р. Македонија на годишно ниво изнесува $33^{\circ}$. Поголем агол на поставување е потребен во месеците во зимскиот период, додека во летниот период аголот на поставување треба да биде помал $\left(25^{\circ}\right.$ до $\left.15^{\circ}\right)$ Табела $2.2^{13}$.

\begin{tabular}{|lccccc|}
\multicolumn{1}{r}{ Месец } & \multicolumn{5}{c}{ Оптимален агол на колекторот, } \\
јануари & Скопје & Битола & Охрид & Берово & Штип \\
февруари & 51 & 61 & 62 & 62 & 60 \\
март & 42 & 53 & 54 & 54 & 53 \\
април & 27 & 27 & 27 & 27 & 27 \\
мај & 14 & 15 & 16 & 14 & 15 \\
јуни & 8 & 8 & 8 & 8 & 8 \\
јули & 12 & 12 & 12 & 12 & 12 \\
август & 23 & 23 & 23 & 22 & 23 \\
септември & 39 & 38 & 38 & 38 & 38 \\
октомври & 52 & 50 & 50 & 51 & 51 \\
ноември & 60 & 59 & 59 & 59 & 59 \\
декември & 60 & 60 & 60 & 61 & 58 \\
\hline Годишно & $\mathbf{3 3}$ & $\mathbf{3 3}$ & $\mathbf{3 4}$ & $\mathbf{3 3}$ & $\mathbf{3 2}$ \\
\hline
\end{tabular}

Табела 2.2 Оптимален агол на поставување на колектор за пет града во Р. Македонија

${ }^{13}$ Славе Арменски, Сончева енергија - термичка трансформација, 2012 


\section{4 Одредување на позиција на Сонце}

При дизајнирање на еден соларен уред од голема важност е познавањето на соларната геометрија, односно позицијата на Сонцето во било кој период. За една површината да прими максимална енергија потребно е сончевите зраци да паѓаат нормално на неа, а бидејќи нивниот агол постојано се менува, кој пак зависи од повеќе фактори, доаѓа до еден важен проблем - определување на аголот на максимално зрачење на одредена површина во просторот.

Положбата на Сонцето во било кој период од денот може да се дефинира со два агли ${ }^{14}: \beta_{\mathrm{N}}$ (altitude) и азимут $\varphi_{\mathrm{S}}$ (Слика 2.12). Аголот на висина (altitude) и азимутот (azimuth) зависат од географската ширина, денот во годината и од периодот на денот. Овие податоци може да се добијат од табели, но практични се дијаграмите на сончеви патеки кои за одредена локација и ден во годината ја покажуваат неговата позиција во текот на денот.

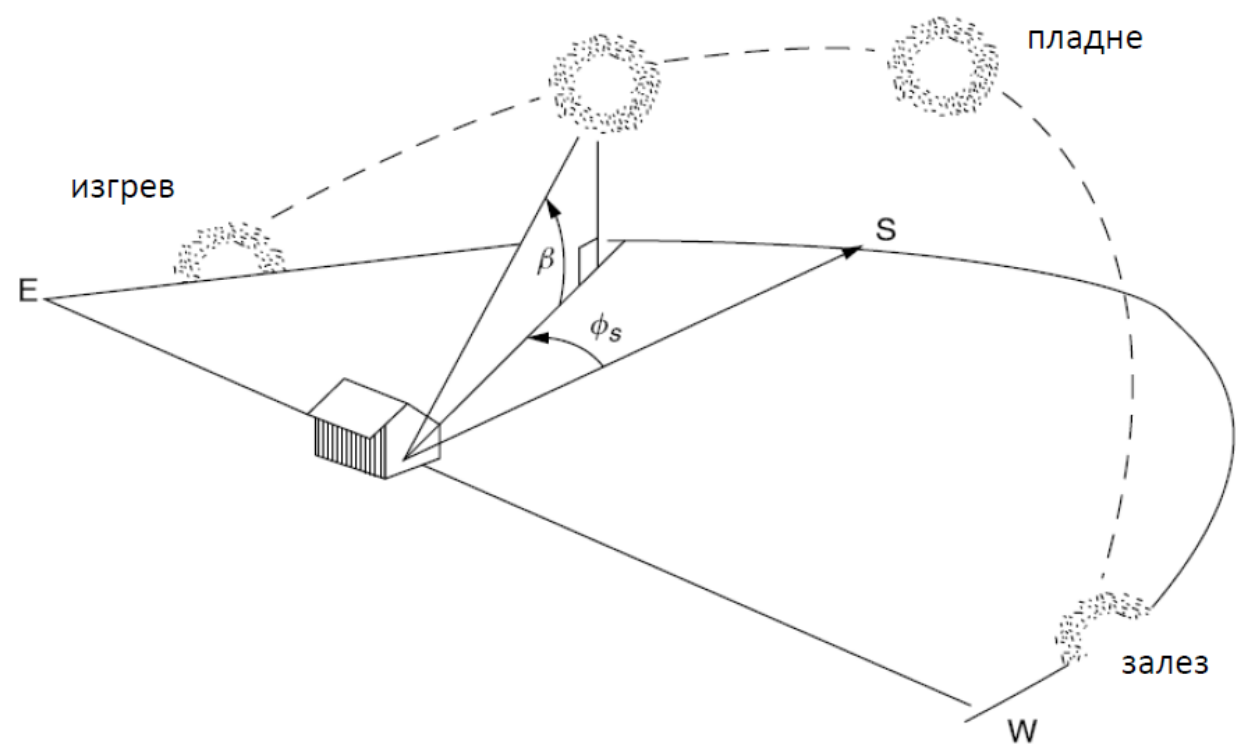

Слика 2.12 Одредување на положбата на Сонцето преку аголот на висина $\beta$ и аголот на азимут $\varphi s$

${ }^{14}$ Славе Арменски, Сончева енергија - термичка трансформација, 2012 


\begin{tabular}{|lccccccccccccc|}
\hline месец & I & II & III & IV & V & VI & VII & VIII & IX & X & XI & XII \\
\hline изгревање & $7: 40$ & $6: 50$ & $6: 00$ & $5: 10$ & $4: 40$ & $4: 30$ & $4: 40$ & $5: 10$ & $6: 00$ & $6: 50$ & $7: 40$ & $7: 50$ \\
\hline заоѓање & $16: 30$ & $17: 20$ & $18: 00$ & $18: 50$ & $19: 20$ & $19: 30$ & $19: 20$ & $18: 50$ & $18: 00$ & $17: 20$ & $16: 30$ & $16: 10$ \\
\hline \multicolumn{7}{|c|}{ Агол на сончевите зраци кон хоризонтална рамина (во } & `) \\
\hline $\mathbf{8 , 0 0}$ & 4 & 12 & 22 & 28 & 34 & 36 & 34 & 28 & 22 & 12 & 4 & 2 \\
\hline $\mathbf{1 0 , 0 0}$ & 18 & 27 & 37 & 47 & 54 & 56 & 54 & 47 & 37 & 27 & 18 & 15 \\
\hline $\mathbf{1 2 , 0 0}$ & 24 & 33 & 45 & 56 & 64 & 68 & 64 & 56 & 45 & 33 & 24 & 20 \\
\hline $\mathbf{1 4 , 0 0}$ & 18 & 27 & 38 & 48 & 55 & 58 & 55 & 48 & 38 & 27 & 18 & 16 \\
\hline $\mathbf{1 6 , 0 0}$ & 5 & 13 & 22 & 29 & 34 & 37 & 34 & 29 & 22 & 13 & 5 & 3 \\
\hline $\mathbf{1 8 , 0 0}$ & - & - & 0 & 8 & 14 & 17 & 14 & 8 & 0 & - & - & - \\
\hline
\end{tabular}

Табела 2.3 ${ }^{15}$ Времетраење на дневното светење и аглите на сончевите зраци кон хоризонтална рамна површина за географска ширина од $45^{\circ}$

\section{5 Апарати за подготовка на храна, потрошувачка на ел. енергија, заштеда}

Во последните години се́ повеќе внимание се посветува на истражување и развој на можностите на обновливите извори на енергија. Но, и покрај тоа што Македонија е опкружена со поволности од аспект на изобилие на сончеви денови во текот на целата година, многу е мал процентот на искористеност на сончевата енергија, кој обично се сведува на системи за загревање на вода. Според енергетскиот биланс ${ }^{16}$, учеството на енергија произведена од сончева енергија, во вкупната потрошувачка на енергија изнесува 7,4 GWh, односно 0,04\%. Според податоците на Државниот завод за статистика на Р. Македонија, во 2012 година, од вкупната бруто-домашна потрошувачка на електрична енергија на домаќинствата отпаѓаaт $36.5 \%{ }^{17}$.

Во Европската Унија од поодамна е воведена класификација на електричните уреди според потрошувачката на електрична енергија, па и производителите сѐ повеќе работат на создавање на апарати за домаќинство кои штедат енергија. Апаратите за домаќинство општо можеме да ги поделиме во повеќе групи, како апарати за загревање на простории,

\footnotetext{
${ }^{15}$ Славе Арменски, Сончева енергија - термичка трансформација, 2012

${ }^{16} \mathrm{http}: / /$ www.ea.gov.mk/index.php?option=com_content\&view=article\&id=53

${ }^{17} \mathrm{http}$ ///www.stat.gov.mk/PrikaziSoopstenie.aspx?.rbrtxt=62
} 
апарати за ладење, апарати за подготовка на храна итн. За тоа колку ел. енергија во просек трошат разни видови на апарати за подготовка на храна е прикажано во Табела $2.4^{18}$.

\begin{tabular}{|l|c|}
\hline Апарат & Вати \\
\hline Дехидратор на храна (сушара) & $\mathbf{3 0 0}$ \\
Микробранова печка & $\mathbf{8 0 0}$ \\
Тостер & $\mathbf{1 1 0 0}$ \\
Електрична скара & $\mathbf{1 2 5 0}$ \\
Решо & $\mathbf{1 5 0 0}$ \\
Ел.шпорет (рингла 15cm) & $\mathbf{1 5 0 0}$ \\
Ел.шпорет (рингла 20cm) & $\mathbf{2 1 0 0}$ \\
Ел. рерна & $\mathbf{4 0 0 0}$ \\
\hline
\end{tabular}

Табела 2.4 Просечна потрошувачка на ел. енергија на апратите за подготовка на храна

Секој електричен уред има моќност која ни кажува колку електрична енергија е потребна за да функционира. Таа обично е дадена во вати (W) или киловати $(\mathrm{kW})$. Износот на електрична енергија која се користи зависи од времетраењето на активното користење на уредот, кое пак се мери во киловат часови $(\mathrm{kWh})$. Пресметувањето на цената на потрошена ел. енергија по апарати е доста едноставно, а за тоа постојат и калкулатори ${ }^{19}$ преку кои со внесување на неколку параметри се доаѓа до резултатите.

\footnotetext{
${ }^{18} \mathrm{http} / / /$ ap.osu.edu/FileStore/PDFs/EM What size generator do I need.pdf

${ }^{19} \mathrm{http}: / /$ elem.com.mk/calculator/index_en.html
} 


\section{3. Соларна енергија во процесот на подготовка на храна}

Припремата на храна е активност која се врши секојдневно заради задоволување на основните животни потреби на луѓето. За таа цел се троши голема количина енергија. Во зависност од намената, животниот стандард и видот на горивото, во светот се употребуваат разни видови на уреди за подготовка на храна. Од обични шпорети на дрво до компјутеризирани печки. Видот на горивото кое се користи има големо влијание како врз животната средина, така и врз квалитетот на храната.

Употребата на соларната енергија за термичка обработка на храната во однос на користењето на традиционалните методи претставува остварлива алтернатива. Веќе се во употреба уреди кои ја користат пасивно соларната енергија, но, овој начин сеуште не може во целост да го замени традиционалниот начин на готвење. Примената на една ваква технологија може да даде голем придонес за ублажување на проблемите со загадувањето на природата, а има и свои економски и социјални бенефити. Токму затоа заслужува да се развива и да биде имплементирана на поинаков, иновативен начин.

\section{1 Краток историски преглед}

Историски гледано, луѓето уште од најрани времиња ја користат енергијата од Сонцето за некаков вид на приготвување на храна, кое најпрво бил само едноставно сушење на готовите плодови од природата. Принципот на стаклена градина може да го сметаме како прв обид за користење на соларната енергија за готвење. Градењето на стакленици за одгледување на градинарски култури било доста популарно во римско време. Многу научници оттогаш знаеле за употребата на стаклото за заробување на топлината, но првиот посериозен чекор е направен од страна на француско-швајцарскиот пронаоѓaч Horace de Saussure кој во 1774год. успеал да го примени овој феномен на малку поинаков начин. Тој изградил минијатурен квадратен стакленик, од 5 кутии една во друга, поставени на црна површина, во чија внатрешност, после повеќе различни експериментирања (на материјали, изолација, надморска височина) се постигнала температура од $110^{\circ} \mathrm{C}$. На тој начин се родила нова технологија, a Saussure се смета за татко на соларниот шпорет. 


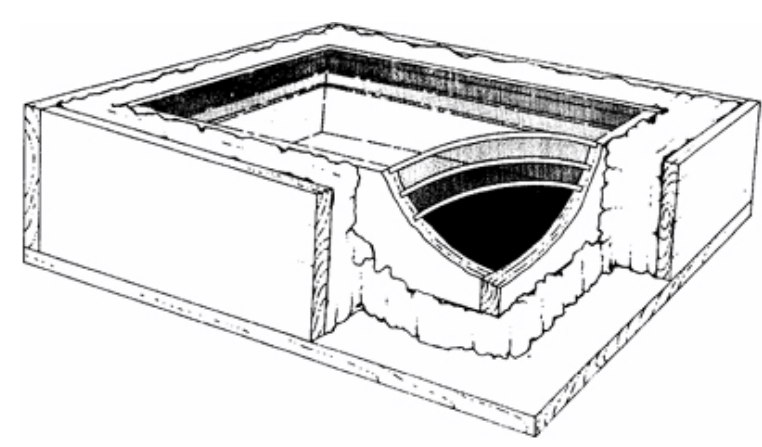

Слика 3.120 Уметничка замисла на усовршената „жешка кутија“ на Horace de Saussure

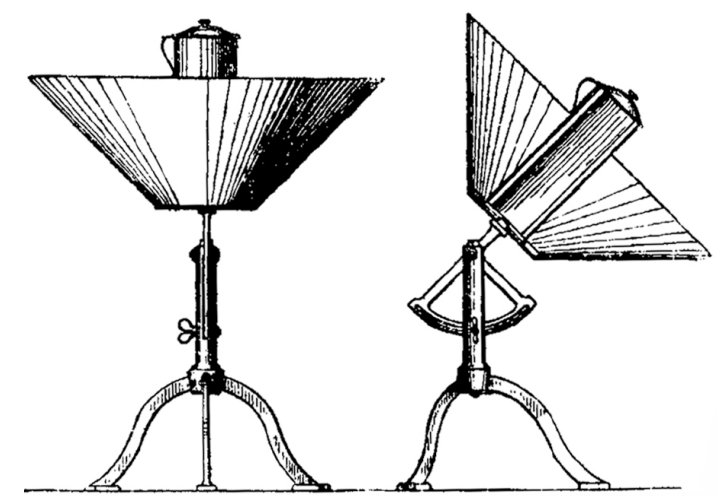

Слика 3.2 Преносен соларен шпорет, развиен од Mouchot, за француските војници во Африка

Друг пронаоѓач кој се занимавал со оваа тематика е французинот Augustin Mouchot. Поддржан од француската влада во 1870-тите години развил пренослив уред за соларно готвење којшто бил користен долги години од страна на француската армија во северноафриканските колонии.

Повеќе научници од 19тиот век изведувале разни експерименти со т.н „жешки кутии“, но соларните шпорети кои нам денес ни се познати, започнале да се развиваат во 1950-тите години, а нивниот развој е уште повеќе поттикнат во 1970-тите од глобалната енергетска криза.

\section{2 Основни карактеристики, видови и конструкции на соларен unopem}

Соларен шпорет е уред кој овозможува готвење на храна со користење на Сонцето како енергенс ${ }^{21}$. Тој функционира на едноставни принципи на рефлексија, концентрација, застаклување, ефект на стаклена градина и апсорбција. Постојат разни видови на соларни шпорети кои користат еден или повеќе од овие принципи. Главно можеме да ги поделиме во 3 категории ${ }^{22}$ :

\footnotetext{
${ }^{20}$ Ken Butti, John Perlin, A Golden Thread: 2500 Years of Solar Architecture and Technology, 1980

${ }^{21}$ Solar Cookers: How to make, use and enjoy, Solar Cookers International, $10^{\text {th }}$ Edition, 2004

${ }^{22}$ Cooking with Sunshine: The Complete Guide to Solar Cuisine with 150 Easy Sun-Cooked Recipes, Lorraine Anderson, Rick Palkovic, 2006
} 
- $\quad$ кутија шпорет (box cooker)

- панел шпорет (panel cooker) и

- високо температурен рефлектирачки (параболичен) шпорет (high-temperature reflector cooker)

Секој тип на шпорет ќе биде опишан според:

$>$ Физичкиот опис

\section{Животниот век}

Цената
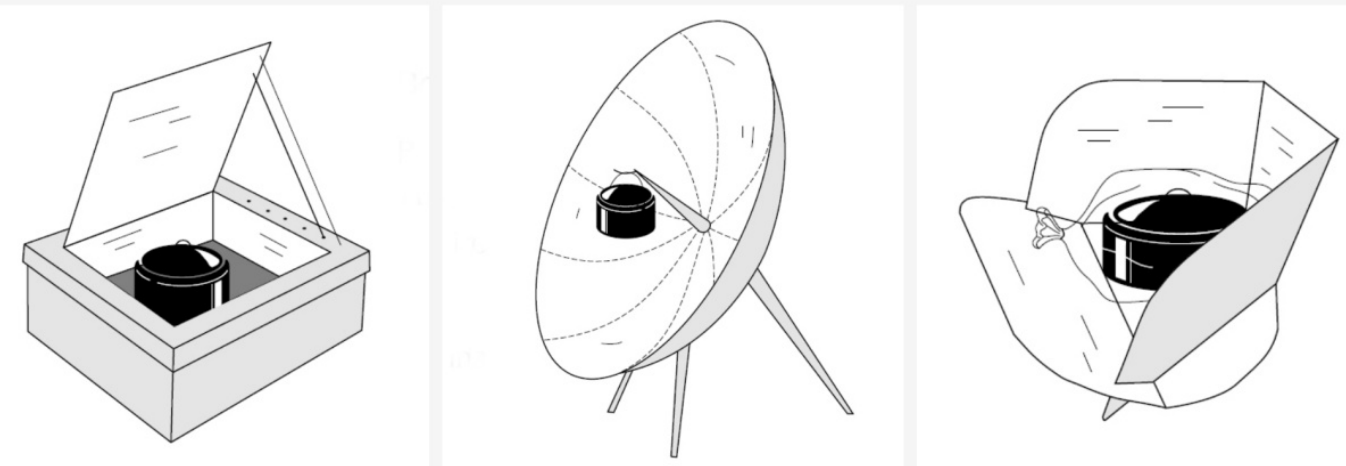

Слика 3.3 Трите основни видови на соларен шпорет - кутија шпорет (лево), параболичен шпорет (средина), панел шпорет (десно)

\subsection{1 Кутија - шпорет}

\section{Физички опис}

Шпорет-кутија претставува добро изолирана кутија во кутија, со провидна горна површина и капак кој ги рефлектира сончевите зраци во кутијата 23 . Од термодинамичка гледна точка, функцијата на овој шпорет е да ја зароби и одржи топлината од Сонцето во него и да ја пренесе на садот за готвење што е можно поефикасно ${ }^{24}$. Ваквото задржување на топлината во внатрешноста се базира на ефектот на стаклена градина. Огледалата се користат за дополнително рефлектирање на сончевото зрачење во комората за готвење, додека двојно изолираните мидови на кутијата служат за одржување на топлината.

Бавниот процес на готвење претставува недостаток. Едноставноста на изградбата и функционирањето со минимално физичко присуство во текот процесот на готвењето е

\footnotetext{
${ }^{23}$ Cooking with Sunshine: The Complete Guide to Solar Cuisine with 150 Easy Sun-Cooked Recipes, Lorraine Anderson, Rick Palkovic, 2006

${ }^{24}$ Thermodynamic Review of Solar Box Cookers, Petri Konttinen, Helsinki University of Technology, 1995
} 
предност. Исто така овој вид на дизајн е стабилен и не постои ризик од пожар и изгореници.

Најчести материјали од кои се изработуваат се дрво, пластика и картон. Ваквиот дизајн направен од едноставна картонска кутија може да постигне температура од $93^{\circ} \mathrm{C}$ до $149^{\circ} \mathrm{C}^{25}$, но храната генерално се готви на $120^{\circ} \mathrm{C}$. Со примена на други материјали може да се достигнат и повисоки температури.

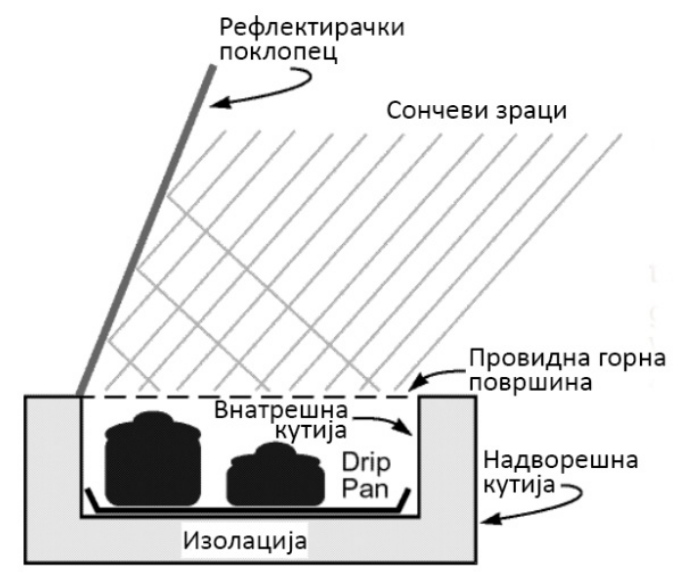

Слика 3.4 Напречен пресек и основни елементи на кутија шпорет

\section{Животен век}

Животниот век зависи од видот и квалитетот на употребениот материјал. „Направи сам“ произведените шпорети кои користат рециклиран материјал нема да траат толку долго како шпоретите направени од поскапи материјали и произведени во работилници со користење на соодветни алати.

Цена

Цената на овој вид шпорети се движи до 150\$, но може да биде и речиси бесплатен во зависност од типот и квалитетот на материјалите.

\subsection{2 Панел шпорет}

\section{Физички опис}

Панел шпоретот како што говори и самото име претставува рефлективен панел кој ги насочува сончевите зраци кон садот за готвење кој е окружен во изолирана школка. Тој

\footnotetext{
${ }^{25}$ Cooking with Sunshine: The Complete Guide to Solar Cuisine with 150 Easy Sun-Cooked Recipes, Lorraine Anderson, Rick Palkovic, 2006
} 
претставува комбинација од принципите на кутија шпорет и параболичен шпорет. Садот за готвење се става во транспарентен стаклен сад или транспарентна најлонска кеса која се заврзува на отворот за да се спречи бегање на воздухот и загуба на топлина. Кесата треба да биде доволно широка за да обезбеди мал изолациски слој на воздух околу садот. Панелот може да биде направен од картон покриен со фолија, огледална површина или некој друг рефлектирачки материјал. Истиот компактно се збира и лесен е за носење и складирање. Ова е наједноставниот и најекономичниот дизајн на соларен шпорет. Развиен е пред 20тина години од непрофитната групација Solar Cooker International ${ }^{26}$ под името CooKit, врз основа на дизајнот на францускиот научник Roger Bernard. Оттогаш зема голем замав. Панел шпоретите може да постигнат температури од $93^{\circ} \mathrm{C}$ до $135^{\circ} \mathrm{C}^{27}$.

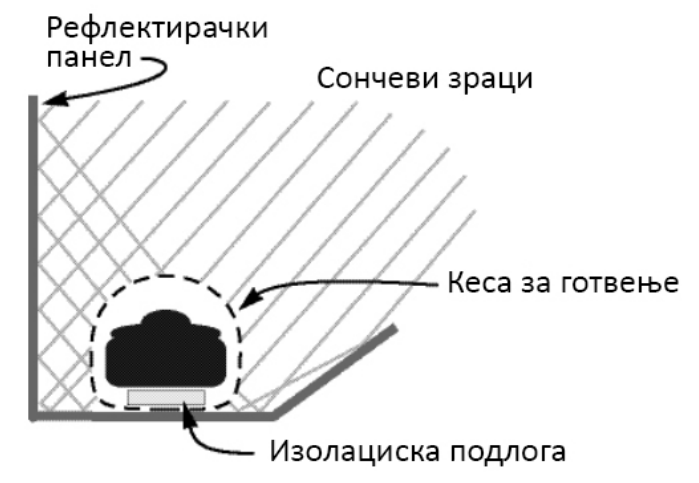

Слика 3.5 Напречен пресек и основни елементи на панел шпорет

\section{Животен век}

Животниот век исто како и кај кутија шпоретите зависи пред се́ од квалитетот на материјалите кои се користат. Едноставен картон прекриен со алуминиумска фолија изложен на разни временски услови (особено дожд) ќе има доста пократок рок на употреба и помала ефикасност.

\section{Цена}

Ова претставува најекономичниот соларен шпорет. Се произведува во вредност од $\$ 3$ - \$7, а бесплатно се достапни и голем број на шеми и планови според кои секој може сам доста едноставно да направи ваков вид на шпорет.

\footnotetext{
${ }^{26}$ https://www.solarcookers.org/

${ }^{27}$ Cooking with Sunshine: The Complete Guide to Solar Cuisine with 150 Easy Sun-Cooked Recipes, Lorraine Anderson, Rick Palkovic, 2006
} 


\subsection{3 Параболичен шпорет}

\section{Физички опис}

Овој вид на шпорет има нешто покомплициран дизајн. Користи закривени рефлектирачки површини за фокусирање на сончевата енергија во една мала област. Најчесто тоа е параболично огледало кое ја концентрира сончевата светлина во фокусот односно врз садот за готвење. Во фокусната точка може да се достигне температура од $315^{\circ} \mathrm{C}^{28}$. Овие шпорети се корисни кога е потребно брзо загревање, но достигнувањето на висока температура може да ги направи опасни.

За да функционираат потребна е директна изложеност на сончева светлина и често позиционирање, односно ориентирање кон Сонцето.

Високата температура што ја постигнуваат за брзо време претставува нивна најголема предност со што се овозможува готвење на буквално секаков тип на храна. Слаба страна е релативно високата цена, постојаното прилагодување, волуменот, како и ризикот од пожар и изгореници. За безбедно

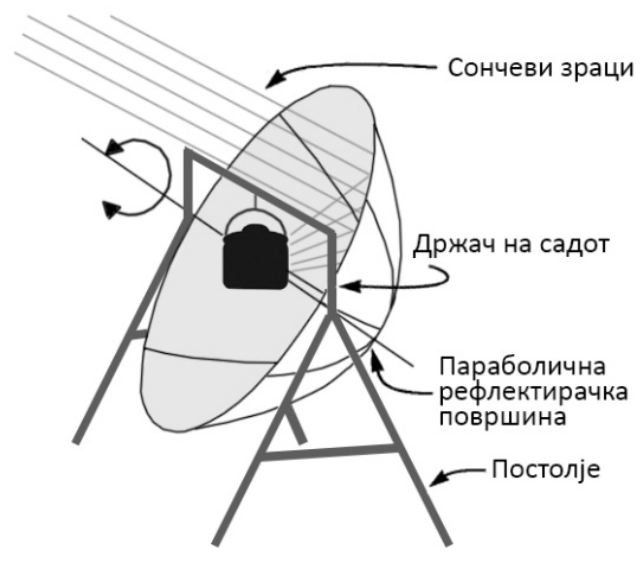
работење потребен е надзор.

\section{Животен век}

Параболичните соларни шпорети имаат долг животен век. Материјалите кои најчесто се користат (алуминиум, челик, нерѓосувачки челик) се доста издржливи.

\section{Цена}

Цената на параболичните шпорети е обично поголема, бидејќи за нивна изработка се користат поскапи материјали. Трошоците се движат помеѓу \$ 20 - \$ 300.

${ }^{28}$ Cooking with Sunshine: The Complete Guide to Solar Cuisine with 150 Easy Sun-Cooked Recipes, Lorraine Anderson, Rick Palkovic, 2006 


\section{3 Предности и недостатоци на основните видови на соларен uпорет}

\begin{tabular}{|c|c|c|}
\hline Вид на шпорет & Предности & Недостатоци \\
\hline Kymuja & $\begin{array}{ll}\checkmark & \text { Го користи и директното и } \\
& \text { дифузното сончево зрачење } \\
\checkmark & \text { Не бара постојано } \\
& \text { позиционирање } \\
\checkmark & \text { Лесен и безбеден за } \\
& \text { користење } \\
\checkmark & \text { Едноставен за } \\
& \text { изградба/конструирање }\end{array}$ & $\begin{array}{ll}\text { x } & \text { Бавно готвење } \\
\text { x } & \text { Не овозможува пржење на } \\
& \text { храната }\end{array}$ \\
\hline Панел & $\begin{array}{ll}\checkmark & \text { Ефтин } \\
\checkmark & \text { Компактен, лесен за носење и } \\
& \text { складирање } \\
\checkmark & \text { Едноставен за правење }\end{array}$ & $\begin{array}{ll}\text { × Слаба ефикасност при облачни } \\
\text { денови } \\
\text { × Готвењето трае подолго } \\
\text { × Не овозможува пржење на } \\
\text { храната } \\
\text { × Нестабилен при ветровито } \\
\text { време }\end{array}$ \\
\hline Параболичен & $\begin{aligned} \checkmark & \text { Доста ефикасен } \\
\checkmark & \text { Може да постигне екстремно } \\
& \text { високи температури (погоден } \\
& \text { за пржење) } \\
\checkmark & \text { Брзо готвење }\end{aligned}$ & 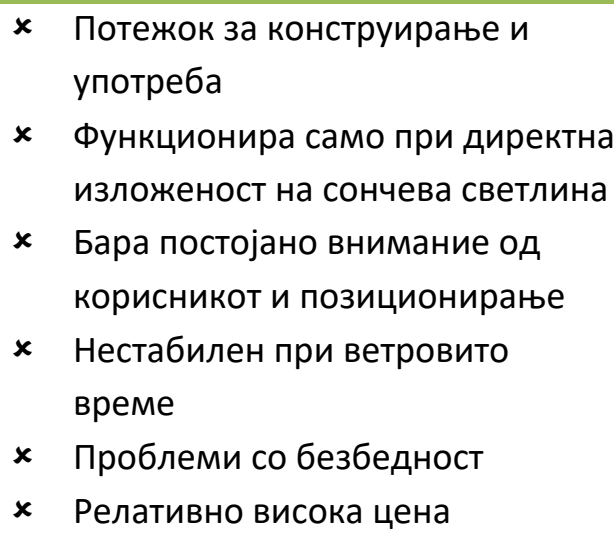 \\
\hline
\end{tabular}

Табела 3.1 Предности и недостатоци на трите основни вида на соларен шпорет

Резултатите од истражувањето ${ }^{29}$ покажуваат дека во зависност од условите, еден вид на шпорет може да биде супериорен во однос на друг. Сепак, при идеални услови, најдобри перформанси имаат параболичните шпорети. Тестирани во сончеви денови без

\footnotetext{
${ }^{29}$ C Z M Kimambo, Development and performance testing of solar cookers, Department of Energy, University of Dar es Salaam
} 
облачност, постигнуваат највисоки температури во однос на сите останати шпорети и соодветно на тоа процесот на готвење е најбрз. Панел шпоретите имаат добри перформанси и при умерено облачни денови, додека кутија шпоретите може да функционираат и во облачни услови. Важно е да се напомене дека сите видови на шпорети постигнуваат најдобри резултати под услови на ведро небо.

\section{4 Времетраење на приготвување на храната со соларен unopem}

Шпоретите на соларна енергија развиваат температури од $82^{\circ} \mathrm{C}$ па нагоре. Ако знаеме дека храната се готви на температури од $82-91{ }^{\circ} \mathrm{C}^{30}$, тогаш е јасно дека дури и наједноставниот соларен шпорет е доволен за извршување на својата задача.
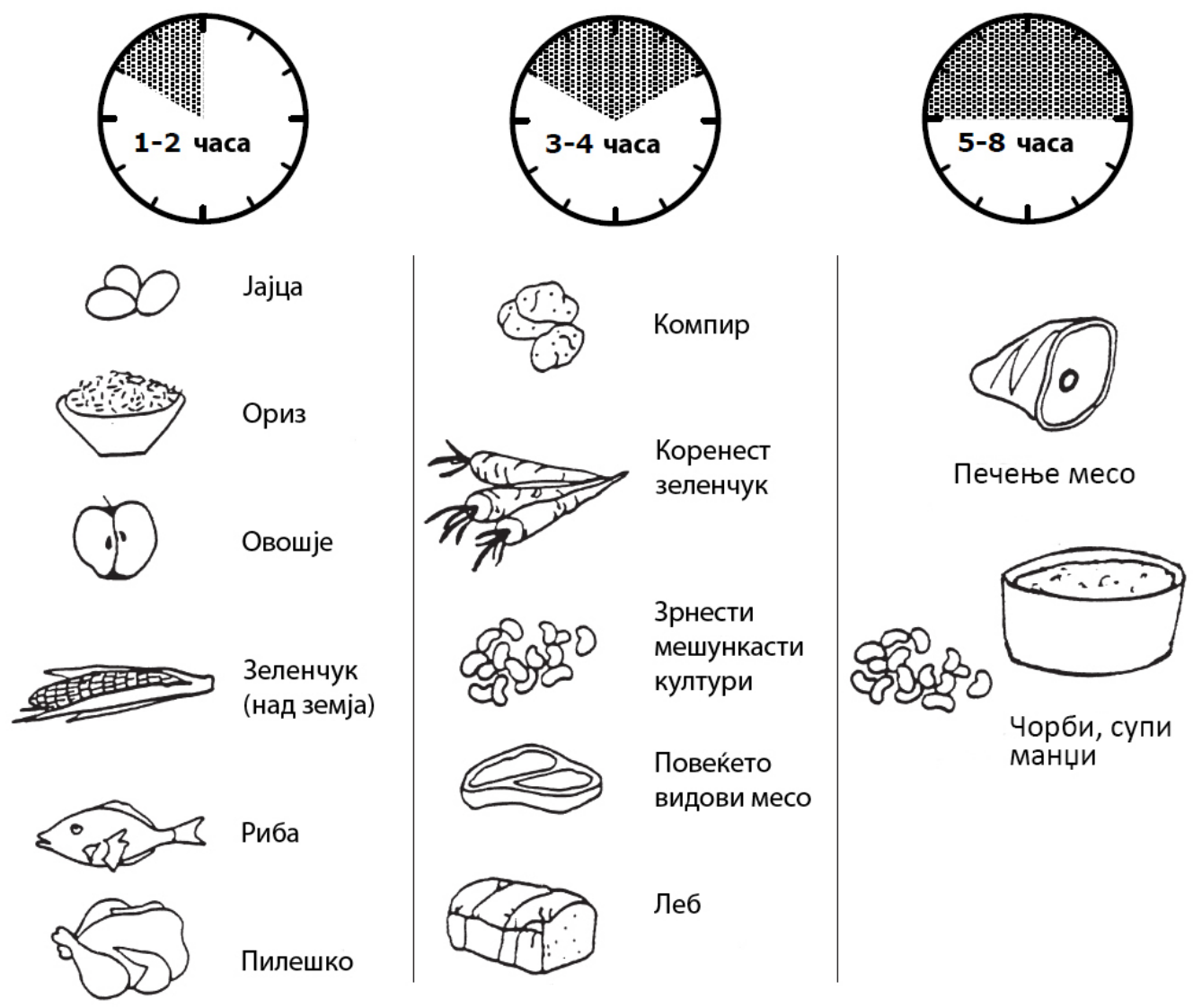

Слика 3.7 Вообичаено време на приготвување на 2 килограми храна во сончев ден

${ }^{30}$ Cooking with the Sun: How to Build and Use Solar Cookers, Dan Halacy, Beth Halacy 
Времетраењето на приготвувањето во однос на конвенционланите уреди е доста поголемо, а зависи од повеќе фактори ${ }^{31}$ : годишното време, периодот од денот, расположливото сончево зрачење, ветерот, типот на садот за готвење, количината и видот на храна. На Слика 3.7 прикажани се повеќе видови на храна и вообичаеното време за нивно приготвување, во количина од 2кг, во сончев ден.

\section{5 Предности и недостатоци на готвењето со соларна енергија}

Откако беше дефинирано што е тоа соларен шпорет, какви видови постојат и на кој начин функционираат, накратко да заклучиме и да ги утврдиме предностите и недостатоците на оваа технологија во процесот на подготовка на храна.

\begin{tabular}{|c|c|}
\hline Предности & Недостатоци \\
\hline $\begin{array}{l}\checkmark \text { Се користи енергијата од Сонцето } \\
\text { која е обновлива, бесплатна и } \\
\text { децентрализирана }\end{array}$ & $\begin{array}{l}\text { × Може да се користи само во } \\
\text { текот на денот на места каде има } \\
\text { доволно сончева светлина }\end{array}$ \\
\hline $\begin{array}{l}\checkmark \text { Не предизвикува никакви } \\
\text { загадувања врз животната средина }\end{array}$ & $\begin{array}{l}\text { × Не може да се задржи топлината } \\
\text { на подолг период }\end{array}$ \\
\hline $\begin{array}{l}\checkmark \text { Помага во намалување на } \\
\text { глобалното затоплување }\end{array}$ & × Процесот на готвење е бавен \\
\hline$\checkmark$ Независност од електричната мрежа & \\
\hline
\end{tabular}

Табела 3.2 Предности и недостатоци при готвењето со соларна енергија

\section{6 Критериуми за избор на соларен шпорет}

На пазарот веќе постојат голем број на соларни уреди за подготвка на храна со различни конструкции и изведби, направени од различни материјали и квалитативни карактеристики. При избор и дизајнирање на еден ваков уред важно е да се запазат следните шест фактори ${ }^{32}$ :

\footnotetext{
${ }^{31}$ SOLAR COOKERS How to make, use and enjoy, Solar Cookers International, $10^{\text {th }}$ Edition, 2004

${ }^{32}$ Evaluation of Several Original and Commonly Used Solar Cooker Designs, Dane Dormio and Steven Jones, Solar Cookers International Network, 2002
} 


\begin{tabular}{|c|c|}
\hline \multicolumn{2}{|l|}{ Фактор } \\
\hline Цена & $\begin{array}{l}\text { Достапноста на материјали и локалани економски } \\
\text { услови. }\end{array}$ \\
\hline Употребливост & $\begin{array}{l}\text { Се однесува на преносливоста на уредот и условите во } \\
\text { кои може да се користи. }\end{array}$ \\
\hline Безбедност & $\begin{array}{l}\text { Се однесува на веројатноста за предизвикување на } \\
\text { пожар, изгореници или слепило. Овие проблеми главно } \\
\text { се јавуваат кај параболичните шпорети кои имаат остар } \\
\text { фокус. }\end{array}$ \\
\hline Готвење & $\begin{array}{l}\text { Потребното време за готвење, максималната и } \\
\text { просечната температура, капацитетот на готвење. Дали } \\
\text { со уредот може да се подготви доволно храна за едно } \\
\text { семејство? }\end{array}$ \\
\hline Трајност и одржување & $\begin{array}{l}\text { Стабилност и издржливост при различни временски } \\
\text { услови, лесна поправка и замена на делови, инструкции } \\
\text { за редовно одржување. }\end{array}$ \\
\hline $\begin{array}{l}\text { Едноставност при } \\
\text { користење }\end{array}$ & \\
\hline
\end{tabular}

Табела 3.3 Фактори за избор на соларен шпорет 


\section{4. Анализа на постоечки уреди на пазарот}

Голем број на уреди за подготовка на храна кои работат на принципот на соларна енергија постојат на пазарот. Според дизајнот и начинот на функционирање претходно ги поделивме во три основни категории, но всушност постојат многубројни конструкции и изведби. Тоа е така бидејќи има доста форми кои може да ја следат функцијата на соларните принципи. Пристапот може да биде ниско или високо технолошки. Нискотехнолошкиот пристап бара само основно познавање на законите за рефлексија со што секој може да биде „дизајнер“ на свој соларен шпорет. Олеснителна околност се и лесно достапните материјали потребни за изработка. Токму едноставноста претставува предност на оваа технологија, но, од друга страна резултира и со недоволно ефикасни и доста лоши естетски решенија.
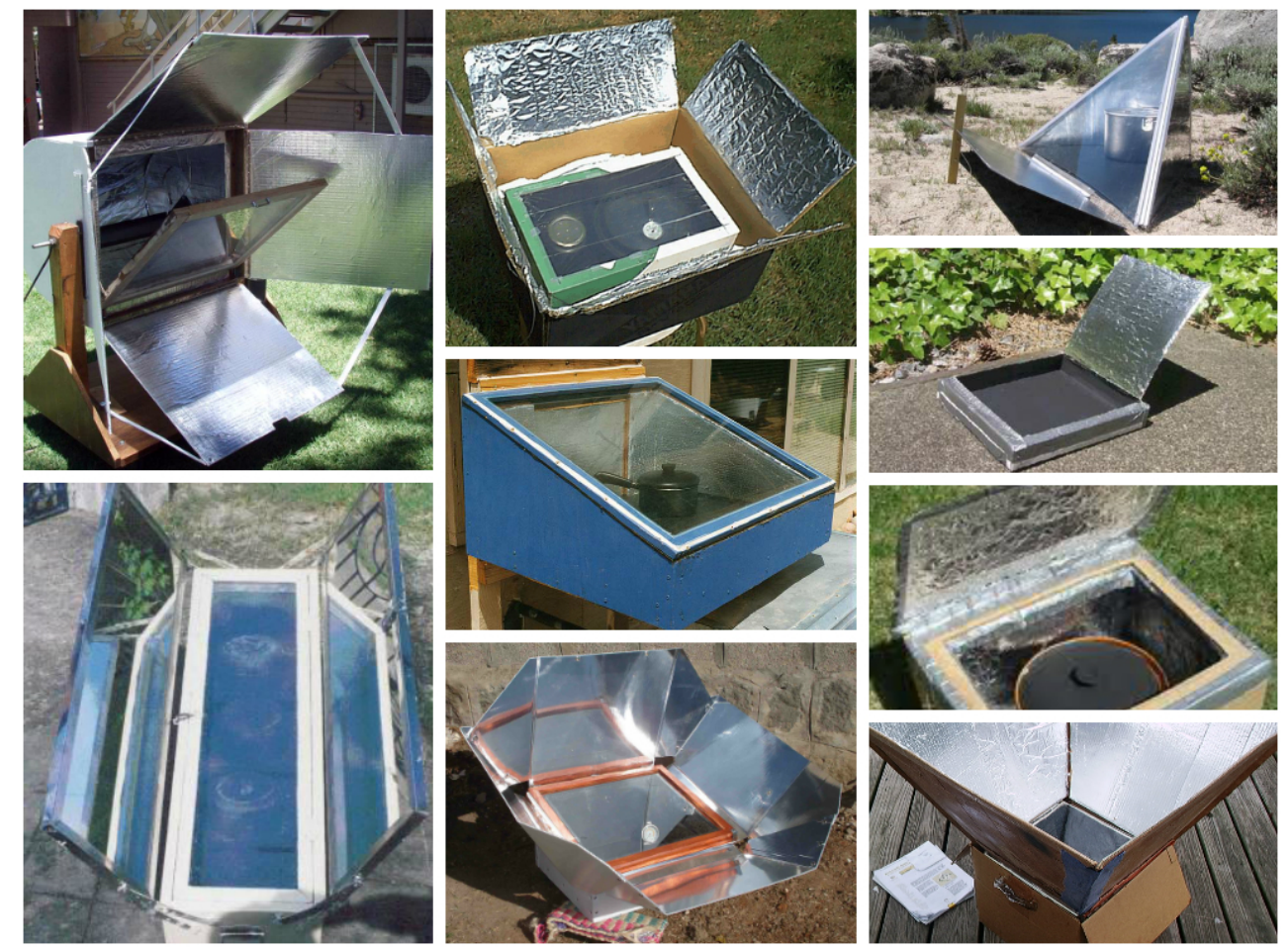

Слика 4.1 Разни видови на кутија-шпорет

Анализата на постоечки уреди на пазарот ќе овозможи да се запознаеме со голем број на дизајнерски решенија почнувајќки од типот „направи сам“ до комерцијалните соларни уреди, како и некои интересни концепти. Согледувањето на нивните предности и недостатоци ќе помогне во развојот на понатамошната дизајнерска идеја. Истражувањето 
ќе ги опфати само малите уреди кои се користат за домашна употреба, пикник и кампување.

\section{1 Некомерцијална употреба}

Постојат повеќе прирачници и книги кои содржат планови и информации за изградба на соларни шпорети за домашна употреба од вообичаени секојдневни материјали. Изборот на материјали (кој треба да е економичен) го диктира и самиот дизајн кој обично се сведува на картонски кутии со примена на тенки фолии, пластика, дрво, стакло итн. Такви примери се прикажани на Слика 4.1, Слика 4.2 и Слика 4.3.

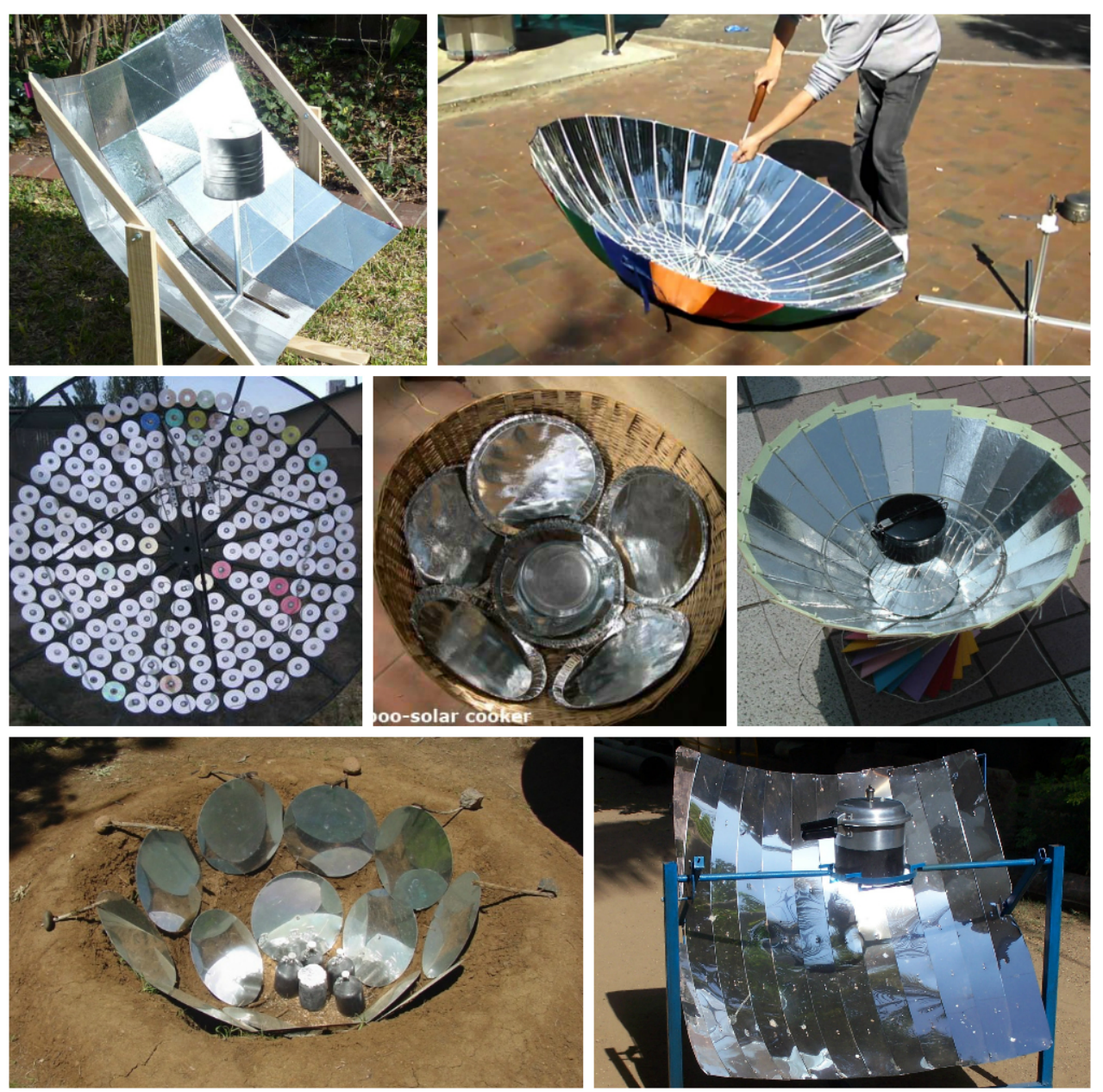

Слика 4.2 Различни дизајни на параболични шпорети

Вакви примери на соларни шпорети постојат многу, повеќе отколку комерцијално произведените. Помалку или повеќе ефикасни, со не така долг век на траење тие ја вршат својата функција. Ограничените и мали ресурси откриваат нови начини на гледање на 
проблемите и можностите, кои пак ја разбрануваат човековата досетливост, креативност и иновативност. И покрај навидум лошиот дизајн кај некои од нив, кој во случајот се однесува само на естетскиот изглед, токму од вакви примери може да се извлечат најдобрите идеи и принципи на работа. Всушност, готвењето со сончева енергија традиционално е наменето за некомерцијална употреба во руралните средини и земјите во развој. Нивното успешно функционирање е причина за почеток на комерцијализација во напредните индустриски земји.
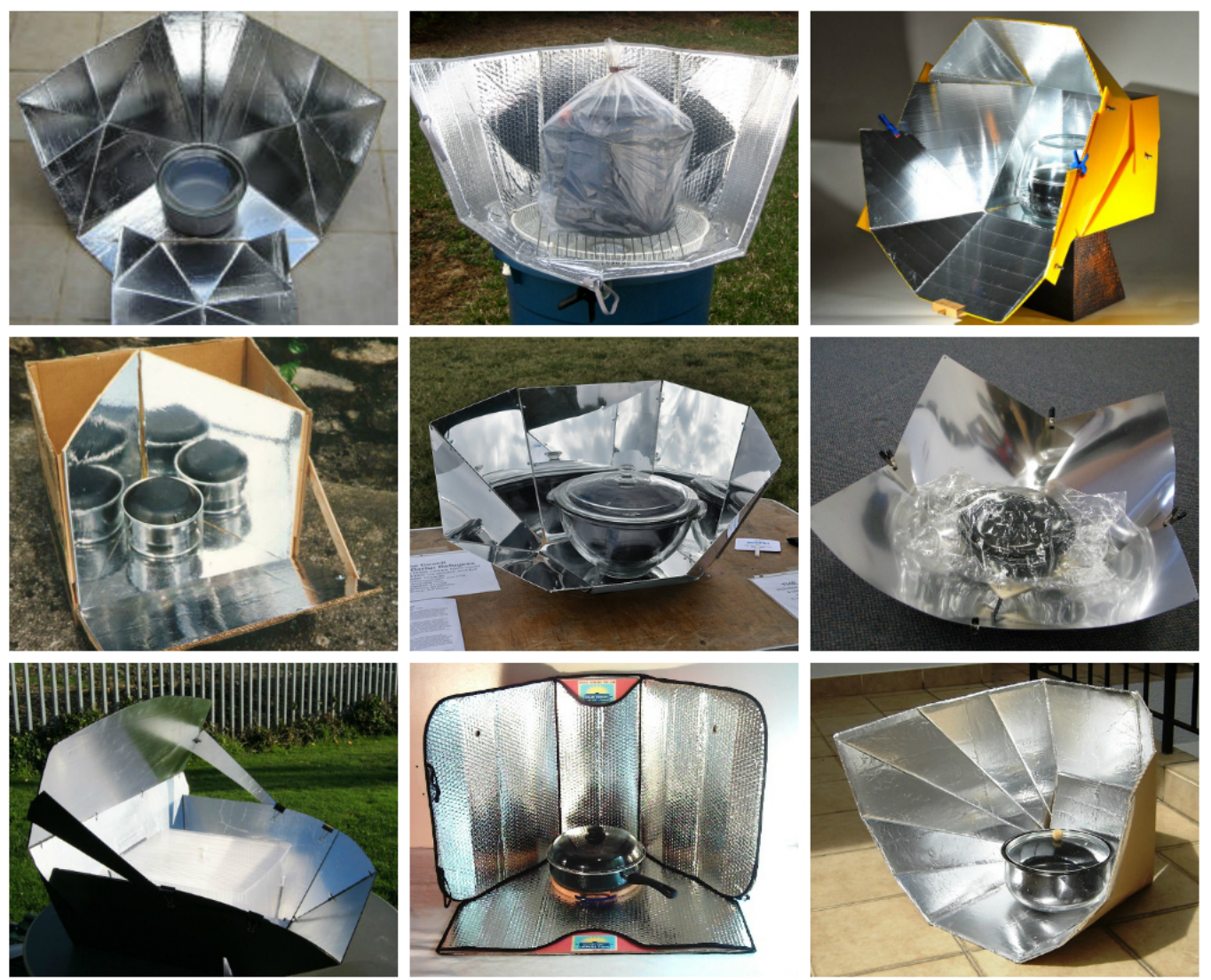

Слика 4.3 Разни дизајни на панел шпорети

\section{2 Комерцијална употреба}

Во последната деценија направен е значаен напредок во индустријата на соларни шпорети особено во процесот на дизајнирање, техничките стандарди, материјалите, подигнување на свеста за потенцијалот итн. Комерцијална употреба подразбира производство на производ со комерцијална вредност, односно во случајот производство на соларни шпорети од страна на производител. Пазарот во развиените земји за комерцијално производство се́ повеќе расте. Во овој дел ќе бидат разгледани неколку 
поинтересни дизајнерски решенија кои веќе се наоѓаат во предсериското или сериското производство.

Еден од веќе етаблираните производители и лидер на европскиот пазар е француската компанија ID $\operatorname{Cook}^{33}$. Таа има развиено цела серија на производи од овој тип, од кои како најинтересен во дизајнерска смисла се издвојува параболичната соларна скара CookUp200 34 прикажана на Слика 4.4.

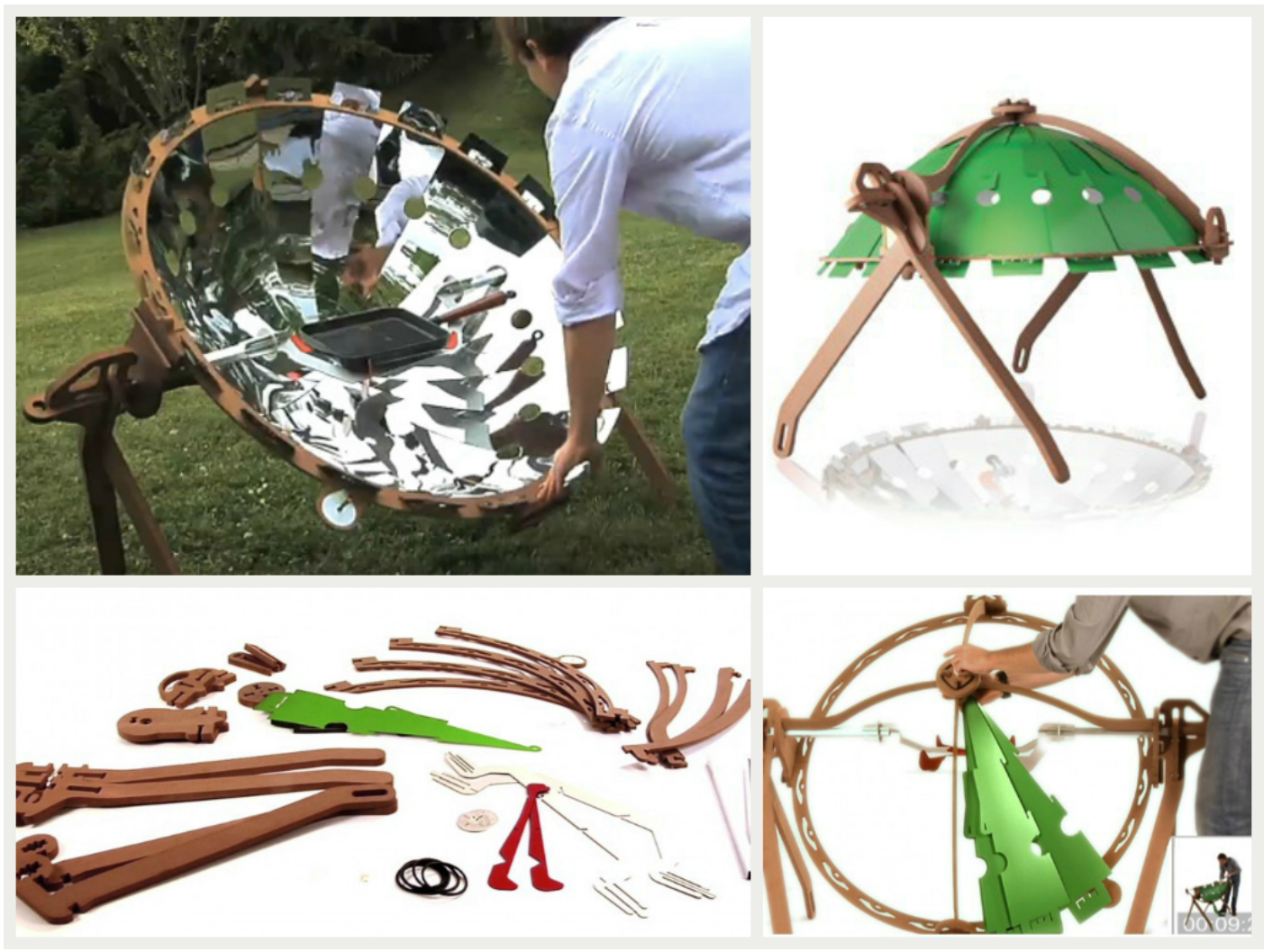

Слика 4.4 CookUp200 целосно расклоплива соларна скара

Оваа соларна скара користи параболичен рефлектор за концентрирање на сончевите зраци. Во центарот, каде се наоѓa садот за храна се постигнува работна температура поголема од $200^{\circ} \mathrm{C}$. Има капацитет за подготовка на храна за пет лица. Целосно е расклоплива, а може да се постави за околу 10тина минути за што не е потребен алат. Деловите можат да бидат лесно заменети. Напрвена е од дрво, алуминиум и ПЕТ пластика со дијаметар на чинијата од $1 \mathrm{~m}$. Цена $400 €$.

\footnotetext{
${ }^{33}$ http://www.idcook.com

34 http://www.idcook.com/en/solar-barbecue-and-solar-grill/7-solar-barbecue-cookup200.html
} 
$\operatorname{GoSun}^{35}$ шпоретот прикажан на Слика 4.5 користи параболични огледала за да ја концентрира сончевата светлина врз стаклена цевка во чија внатрешност се готви содржината од храна. Цевката е направена од боросиликатно стакло кое е отпорно на термички шок, а за да се изолира внатрешноста под површината има вакуум. Внатрешноста на цевката е обложена со бакар, не’рѓосувачки челик и алуминиум за да може подобро да ја апсорбира и спроведува топлината од сончевите зраци. Вкупната нејзина должина која всушност ја претставува зоната за готвење, изнесува $61 \mathrm{~cm} \mathrm{и}$ дијаметер од 5,8cm. Со тоа е обезбеден простор за $1,4 \mathrm{~kg}$ храна или 1,61 течност. Постигнува работна температура од $93^{\circ} \mathrm{C}$ до $288^{\circ} \mathrm{C}$. Металните држачи и параболичното огледало се собираат заедно околу стаклената цевка формирајќи компактен пакет со димензии 61×20x13cm. Неговата цена изнесува 299\$.

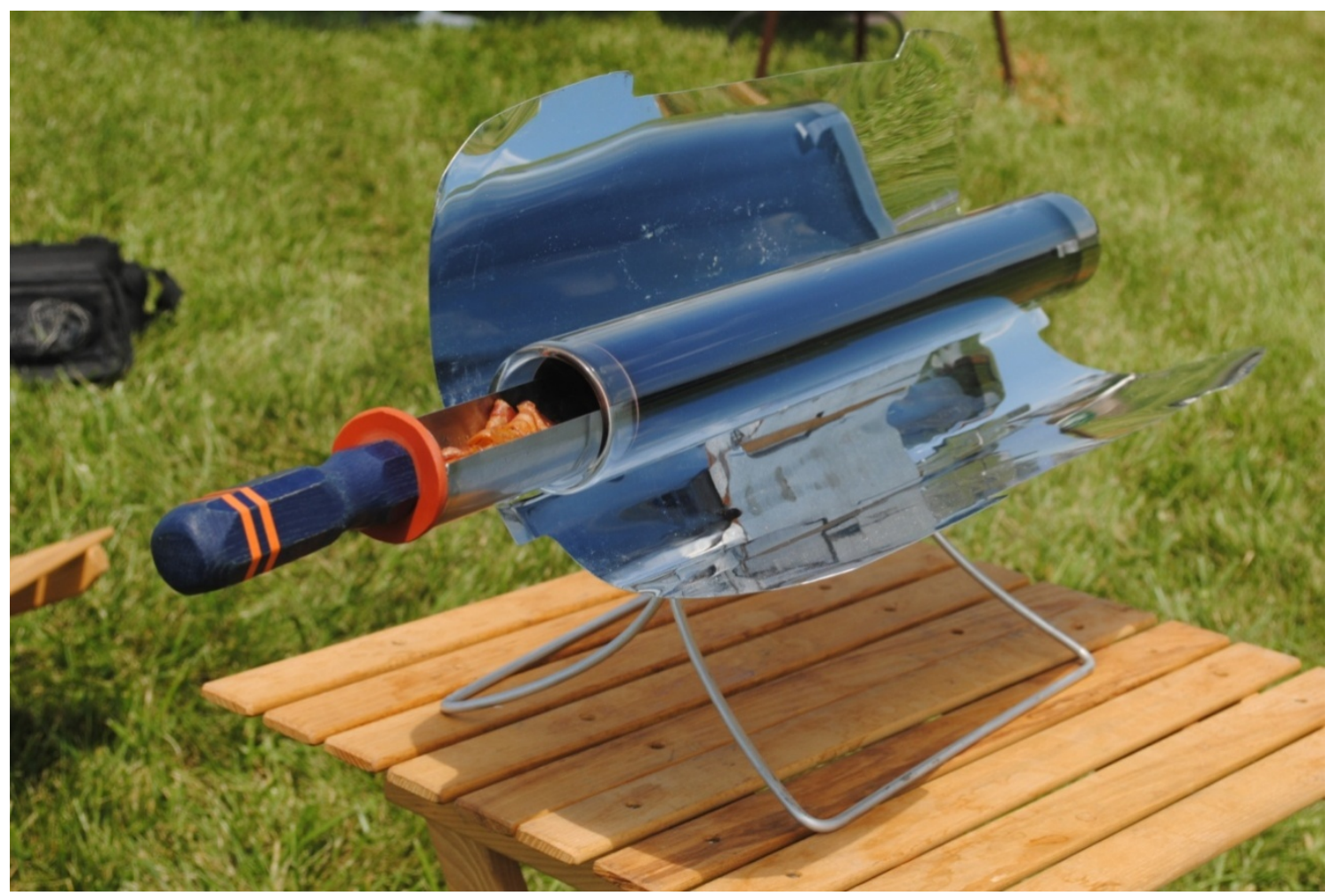

Слика 4.5 GoSun параболичнен шпорет

Lightoven $1^{36}$ е уште еден ефикасен и пренослив соларен готвач со мала тежина чиишто дизајн е инспириран од панел шпоретите. За разлика од нив наместо да користи неколку рефлектирачки панели, тој е направен од многу вертикални сегементи кои

\footnotetext{
${ }^{35} \mathrm{http}: / /$ www.gosunstove.com

${ }^{36} \mathrm{http}: / / \mathrm{www}$. lightoven.de
} 
формираат параболична крива. Ако досега имавме фокусна точка, сега имаме вертикална фокусна линија, каде за постигнување на оптимални резултати треба да биде поставен цилиндричен сад за готвење.
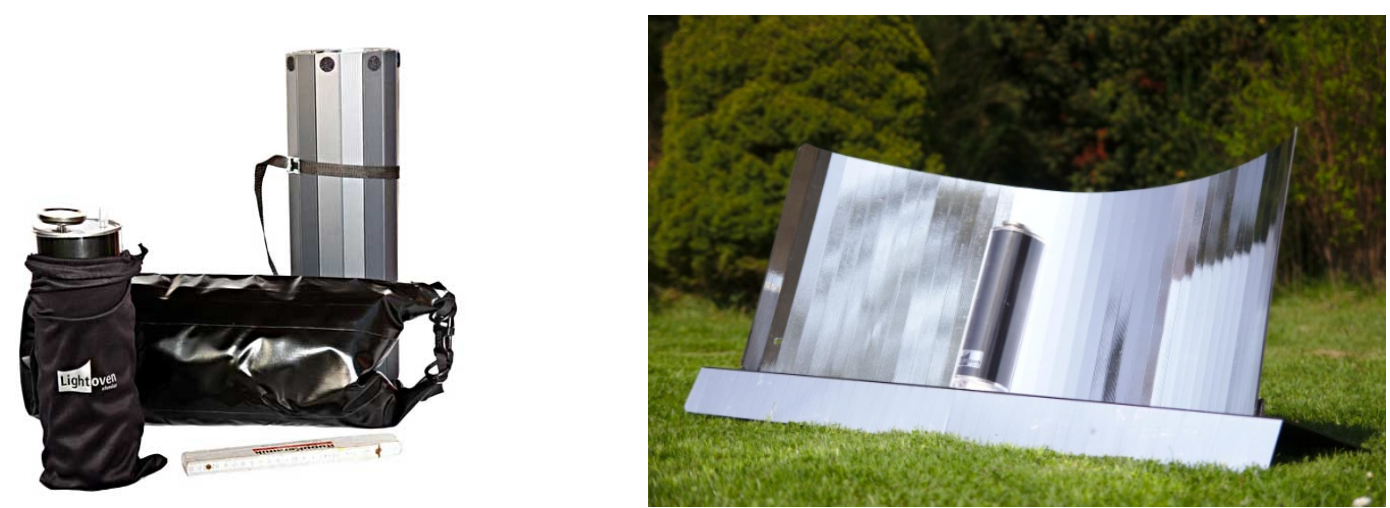

Слика 4.6 Lightoven 1 во затворена (лево) и отворена положба (десно)

Дизајнер: Hartmut Ehmler

Посебно внимание е посветено токму на дизајнот на садот кој е направен од чист алуминиум со многу добри термички својства на спроводливост и интегриран термометар на капакот кој овозможува прецизно следење на процесот на готвење. Однадвор садот е изолиран со транспарентна поликарбонатна цевка што служи за да го задржи топлиот воздух и термалната радијација. Собира 1,51 течност (вода). За компактност на уредот при транспорт, двата рефлектирачки панели се дизајнирани лесно да свиткуваат околу садот. Димензиите на рефлекторите кога се во функција изнесуваат 114 x 45 x 45 cm (ширина, висина и длабочина), додека во затворена положба должината е $45 \mathrm{~cm}$ со дијаметар од $17 \mathrm{~cm}$. Вкупната тежина изнесува $1,6 \mathrm{~kg}$. Цена $179 €$.
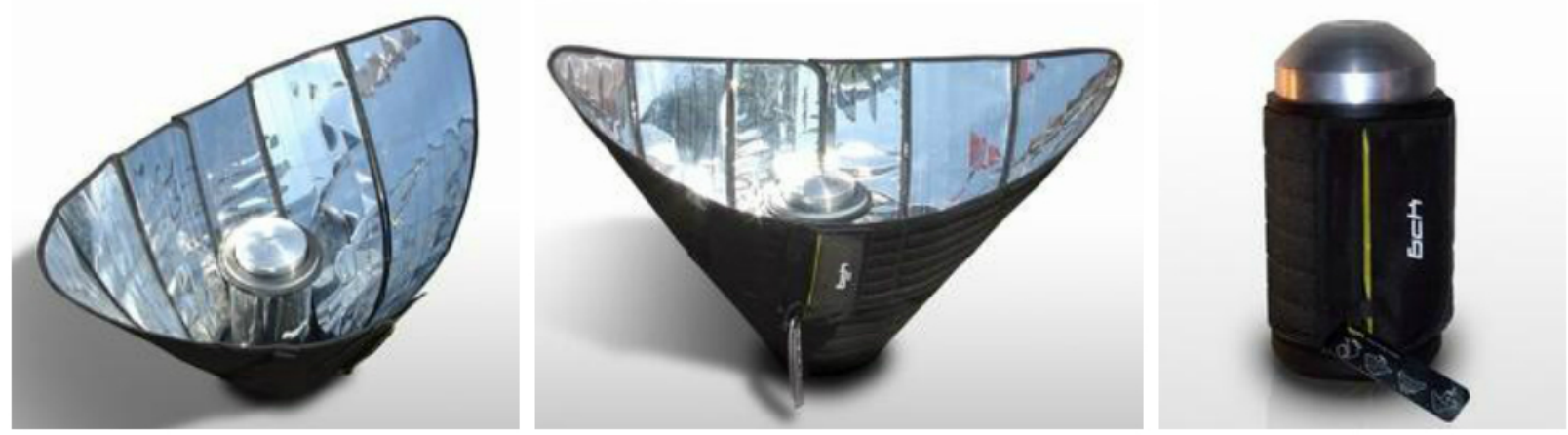

Слика 4.7 ВСК соларен уред

Дизајнери: Javier Bertani, Ezequiel Castro \& Vera Kade. 
Соларниот уред $\mathrm{BCK}^{37}$ е расклоплив и лесно пренослив кој како и претходно споменатите се користи за готвење користејќи ја само сончевата светлина. Во својата затворена положба наликува на термос, но кога е поставен има конусна форма. Конусниот заклон ги рефлектира сончевите зраци во центарот на конусот каде црна цилиндрична кутија за храна ја собира топлината. Големината во затворена положба изнесува $25 \mathrm{~cm}$ во висина и $13 \mathrm{~cm}$ во дијаметар. Може да загрева до температура од $90^{\circ} \mathrm{C}$.

\section{3 Концепт решенија}

Во овој дел прикажани се неколку концепт идеи на поединци, кои за разлика од претходно изнесените примери, не се наоѓаат во производство или фаза на прототип.

Соларниот концепт на шпорет прикажан на Слика 4.8 е инспириран и дизајниран за помош при вондредни состојби (природни катастрофи, бегалски кампови и сл.). Компактен е, лесно се отвора и склопува во неколку чекори. Лесен е за транспорт и треба да претставува привремена кујна кога електричната енергија е недостапна.
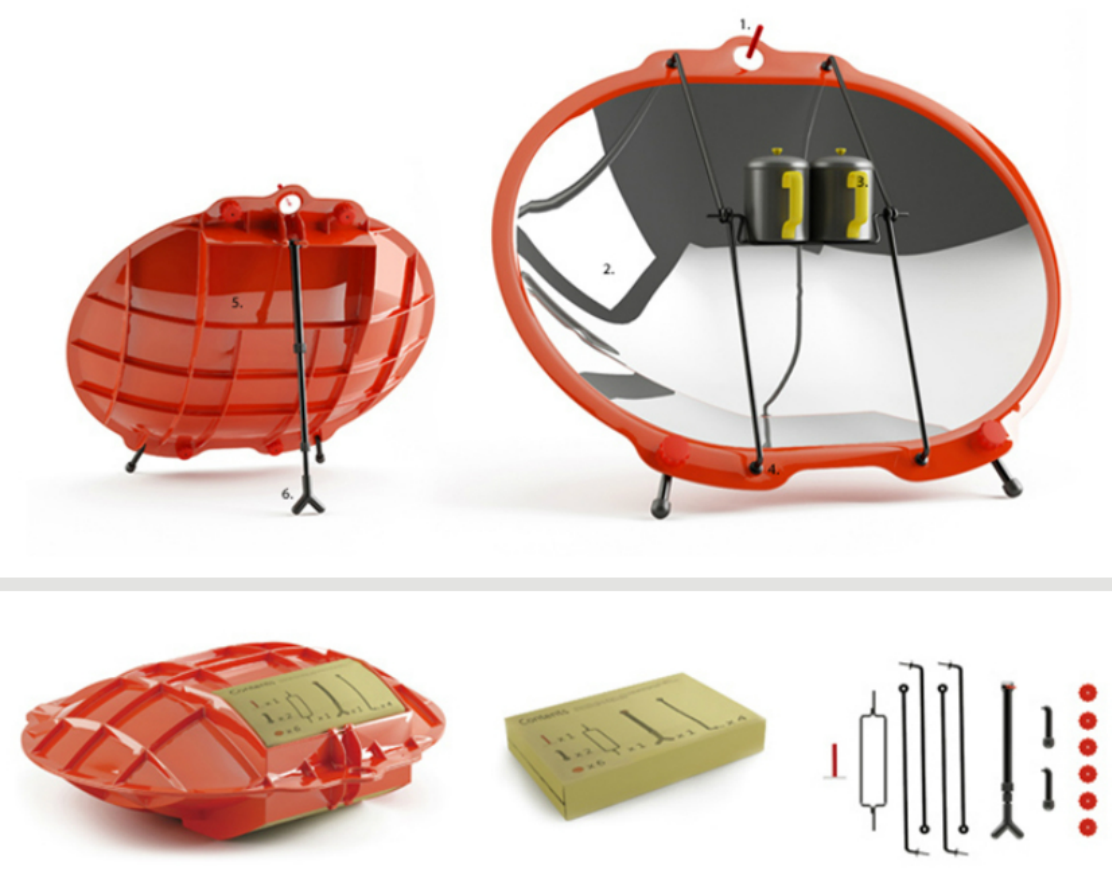

Слика 4.8 Соларен готвач за вондредни состојби

Дизајнер: Cheng - Tsung Feng

\footnotetext{
${ }^{37} \mathrm{http}$ ://solarcooking.wikia.com/wiki/BCK_Solar_Cooker 
Дизајнот всушност претставува комбинација од два соларни шпорети поставени еден наспроти друг во чија внатрешност е предвидено да се најдат основни продукти како сува храна и вода.

Вториот концепт прикажан на Слика 4.9, замислен е како расклоплив параболичен рефлектор со вградена опрема за автоматско следење на сончевите зраци од $360^{\circ}$ кој го насочува рефлекторот секогаш во вистинската положба. Исто така предвиден е механизам за прилагодување на височината кој служи за создавање на различни функции на затоплување (пр. концентриран зрак за вриење или дифузен зрак за печење), како и тајмер за готвење и практично телескопско подножје. Се́ што треба да се направи е да се прилагоди времето и интензитетот на топлина.

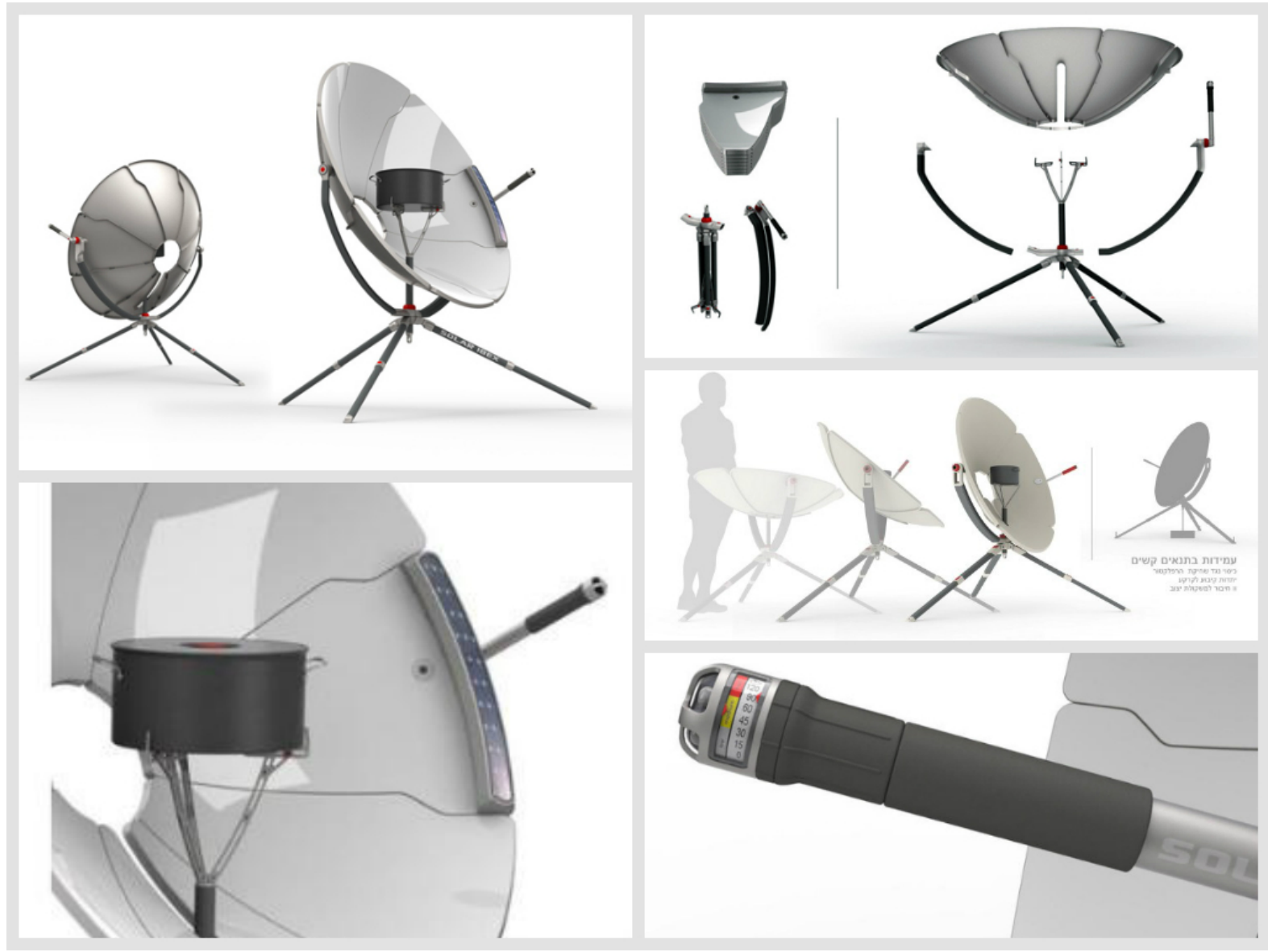

Слика 4.9 Solar Ibex - параболичен соларен готвач

Дизајнер: Nir Beit-av 


\section{4 Материјали}

Важна задача во развивањето на еден производ е да се одредат потребните материјали за негова изработка. Со познавањето на нивните карактеристики како и потребите на производот може да се направи правилен избор. Постојат неколку критериуми според кои треба да се водиме во донесувањето на одлуката, а тоа се ${ }^{38}$ :

1. Да се дефинираат условите при кои ќе биде употребен материјалот, а кои се во директна врска со својствата на материјалот.

2. Да се земе предвид можноста за промена на својствата на материјалот за време на неговото користење. На пример, какво е однесувањето на материјалот во корозивни средини и при високи температури.

3. Цената на чинење. Да се најде материјал кој ке има одлични својства, но сепак, да не биде премногу скап.

Според функцијата која ја имаат, материјалите кај соларните шпорети можеме да ги поделиме на: конструкциски материјали, рефлектирачки материјали, изолациски материјали, транспарентни материјали за постигнување на ефектот на сткалена градина и материјали кај садовите за готвење.

\subsection{1 Конструкциски материјал}

Конструкциските материјали ја даваат статиката, формата и обликот. Потребно е да имаат добра цврстина, да бидат лесни, флексибилни и трајни во текот на времето (во однос на честа употреба и условите од животната средина). Кај соларните шпорети како конструкциски материјали најчесто се употребуваат метал и пластика, но и дрво, стакло, картон, цемент, тули, глина.

\subsection{2 Транспарентен материјал}

Транспарентната покривка кај соларните шпорети обезбедува затоплување преку ефектот на стаклена градина. Најчест материјал кој се користи за извршување на оваа

\footnotetext{
38 Е.Фиданчевска, В. Сребренкоска, Инженерство на материјали, Темпус проект Tempus 158989-Tempus-12009-1-BE-Tempus-JPHES “Creation of university-enterprise cooperation networks for education on sustainable technologies
} 
задача е стаклото, но може да се користат и некои видови на полимери. Повеќето пластични материјали го спороведуваат сончевото зрачење исто како и стаклото, отпорни се на механички оштетувања, но под дејство на ултравиолетовото зрачење се деградираат. Стаклото пак не се деградира, но при изборот треба да се внимава на можноста за механичко оштетување. Поради тоа најчесто се користи калено (сигурносно) стакло кое е појако и поиздржливо од стандардното стакло. Има извондредна отпорност на кршење. Дури и да дојде до кршење, тоа е во форма на мали правилни парчиња, без остри делови кои би предизвикале повреда. За зголемување на трансмисијата на светлина се користи стакло со ниско ниво на железо кое има поголема транспарентност од обичното (Слика 4.10).

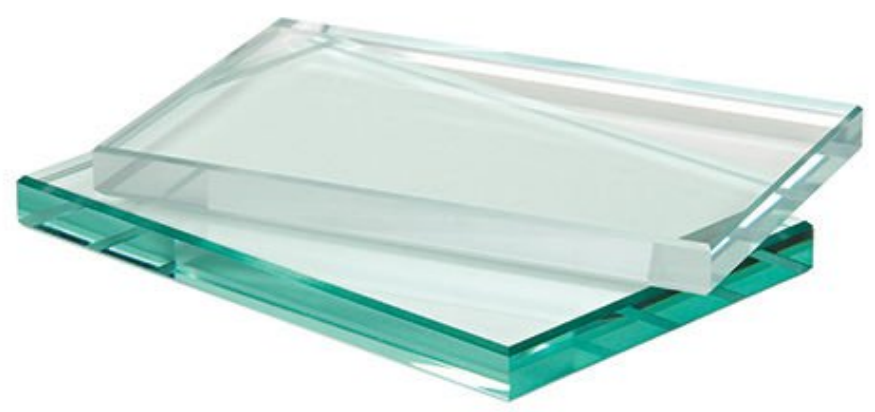

Слика 4.10 Стакло со ниско ниво на железо (low-iron glass)

\subsection{3 Изолационен материјал}

Со цел да се постигнат температури доволно високи за готвење кај кутијашпоретите потребно е нивно изолирање. Изолационите материјали треба да овозможат минимално спроведување на топлина од внатрешната кон надворешната кутија. Колку помала загуба на топлина толку повисоки температури за готвење. Материјалот за топлинска изолација треба да биде незапалив на темератури до $300^{\circ} \mathrm{C}$, да има низок коефициент на термичка спроводливост, да не се топи или испушта токсични гасови, да е еколошки подробен и да содржи рефлекторска површина која ќе ја рефлектира загубата на 
енергија назад кон абсорберот ${ }^{39}$ (садот за готвење). Некои изолациони материјали и степенот на нивна термичка спроводливост се прикажани во Табела 4.1.

\begin{tabular}{|lc|} 
Материјал & $\begin{array}{c}\text { Термичка } \\
\text { спроводливост } \\
\text { W/m C }\end{array}$ \\
\hline Воздух & 0,03 \\
\hline Полиутеранска пена & 0,03 \\
\hline Стаклена волна & 0,04 \\
\hline Плута & 0,04 \\
\hline Волна & 0,05 \\
\hline Памук & 0,06 \\
\hline Струготини & 0,06 \\
\hline Хартија & 0,18 \\
\hline Дрво & $0,1-0,2$ \\
\hline Песок & 0,3 \\
\hline Глина & 0,5 \\
\hline Стакло & 0,8 \\
\hline Почва (сува) & 1 \\
\hline Бетон & 1,04 \\
\hline
\end{tabular}

Табела 4.1 Материјали и нивната термичка спроводливост

\subsection{4 Рефлектирачки материјал}

Совршен рефлектирачки материјал е оној кој ќе обезбеди висока оптичка рефлексија, ќе биде отпорен на УВ зраците, издржлив на различни временски услови, да може да се сврзе на друга подлога, еластичен но и лесно достапен и економичен ${ }^{40}$. Материјалите кои во моментот се користат се движат во опсегот од кујнска алуминиумска фолија до сложени материјали развиени од страна на големите корпорации.

Алуминиумот е многу чест материјал кој се користи и е прилично ефтин. Чистиот алуминиум има слаби структурни својства, па затоа најчесто се користат негови легури. Овие легури можат да бидат полирани, но без заштитен слој тие подлежат на прилично брза атмосферска корозија. Производите од алуминиум кои се очекува да траат подолг временски период мора да бидат обложени со заштитен слој. Полираниот анодизиран

${ }^{39}$ Славе Арменски, Сончева енергија - термичка трансформација, второ издание, 2012

40 J.Harrison, Investigation of Reflective Materials for the Solar Cooker, Florida Solar Energy Center, 2001 
алуминиум има висока рефлективност и претставува добар избор за рефлектирачката површина кај соларниот готвач.

Огледалото исто така има добри оптички карактеристики. Акрилното огледало е со тежина половина помала од тежината на стаклото. Отпорно е на кршење и високо рефлективно. Во однос на рефлектирачките својства квалитетот е многу сличен како и кај обичните огледала.

Постојат и разни видови на високо рефлективни бои како и материјали од полиестер и boPET (Biaxially-oriented polyethylene terephthalate) пластика познати под бренд имињата Mylar, Melinex, ReflecTech Mirror и сл.

\subsection{5 Материјали кај садовите за готвење}

Многу е важно да се внимава на материјалите од кои се изработени садовите како поради условите кои ги наметнува самото готвење со соларна енергија, така и поради процесот на реактивност кој се јавува помеѓу храната и садовите, а се забрзува под дејство на висока температура.

Доколку материјалите и нивните карактеристики ги разгледуваме од страна на потребите кои се јавуваат кај готвењето со соларна енергија, тогаш пожелни се материјали кои апсорбираат сончева светлина, во темна боја, направени од тенок материјал со добра спроводливост. Металот е материјал кој се затоплува брзо, за разлика од керамиката или глината. Кај садовите од лиено железо процесот на загревање на почетокот е спор, но доколку има солидни сончеви услови ќе функционира добро. Алуминиумот како материјал одлично ја спороведува топлината, има мала тежина, лесно се чисти и одржува, но спаѓа во групата на реактивни материјали и не се препорачува за користење. Во оваа група влегуваат и садови од тефлон, бакар и пластика. Во однос на реактивноста подобар избор претставува не'рѓосувачкиот челик - инокс и лиеното железо, додека емајлираните садови, садовите од стакло, дрво, глина и се најдобри. 


\section{5. Дефинирање на карактеристиките на новиот концепт}

Претходно спроведените истражувања во областа на соларната енергија и големиот потенцијал кој го нуди, како и можностите на веќе постоечките уреди за готвење на соларна енергија, но и нивната недоволна комерцијална употреба беа инспирација за развивање на нов концепт на пренослив уред од овој вид. За таа цел најнапред потребно е да се дефинираат карактеристиките кои треба да ги поседува, а ќе ни дадат насоки за понатамошен развој на новиот концепт на производ.

Некои од карактеристики се однапред утврдени и мора да бидат запазени бидејќи ги диктира самата наука, односно основните физички закони. Со тоа се наметнува одредено ограничување во делот на обликот и формата на идејните решенија. Но, токму во тоа се состои предизвикот. Запазувајќи ги овие карактеристики, како и барањата на корисниците кои ќе бидат утврдени, неопходно е да се даде дизајнерски одговор со оригинално и

функционално решение. За таа цел најпрво се спороведува анкетен прашалник преку кој ќе се испитаат навиките и барањата на купувачите, а преку куќата на квалитет тие ќе бидат трансформирани во инженерски спецификации.

\section{1 Анализа на анкетни резултати}

Анкетниот прашалник беше спроведен врз примерок од 61 испитаник. Целите беа да се увидат навиките при процесот на подготовка на храна како во домашни услови така и на отворено, но и запознаеноста на испитаниците со концептот на соларен шпорет и еколошката свест.

Првите прашања во истражувањето се однесуваа на демографските карактеристики на испитаниците. Иако навидум доста општи и едноставни, сепак даваат корисни информации од кои како најважен се издвојува податокот за големината на домаќинството. Тоа е важно кога станува збор за одредување на капацитетот на соларниот шпорет. Од спроведеното истражување се дојде до податок дека 75,4\% од домаќинствата бројат од 3 до 5 члена. 
При понатамошното истражување се увиде дека иако кај 78,7\% од домаќинствата се подготвува иста храна за целото семејство (Графикон 5.1), кај 42,4\% се јавува потреба за подготвка на различен вид за секој член посебно (Графикон 5.2). Тоа е барање на потрошувачите кое не треба воопшто да се занемари, туку напротив да се пронајде начин како правилно преку процесот на дизајнирање да се задоволи оваа потреба.

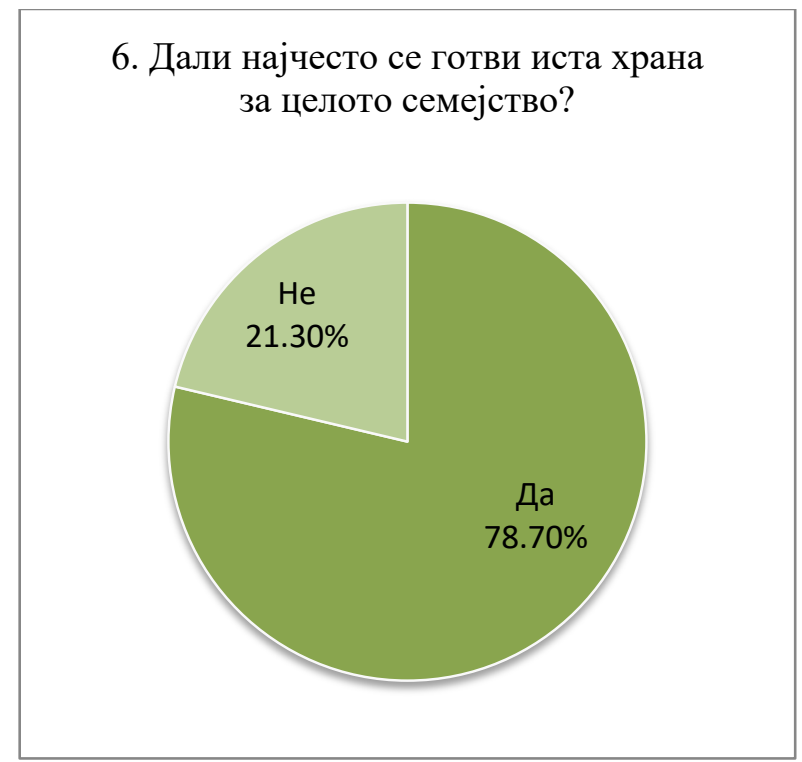

Графикон 5.1

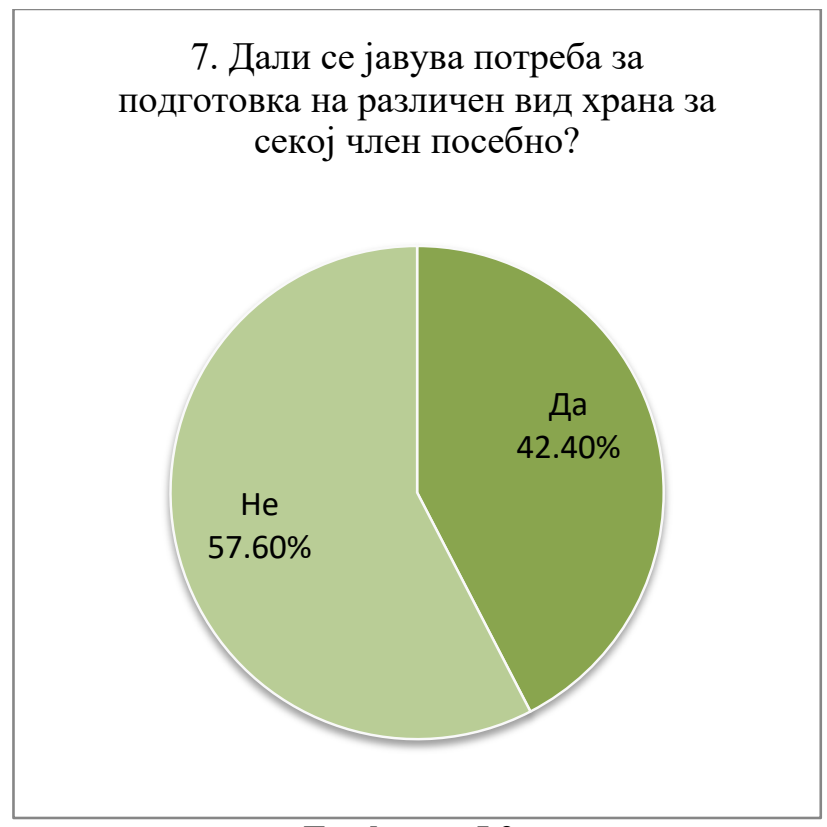

Графикон 5.2
6. Дали најчесто се готви иста храна за целото семејство?

$\begin{array}{lrr}\text { Одговор } & \begin{array}{r}\text { Број на } \\ \text { испитаници }\end{array} & \text { Процент } \\ \%\end{array}$

Табела 5.1
7. Дали се јавува потреба за подготовка на различен вид храна за секој член посебно?

$\begin{array}{lrr}\text { Одговор } & \begin{array}{r}\text { Број на } \\ \text { испитаници }\end{array} & \text { Процент } \\ \text { Да } & 25 & 42,4 \% \\ \text { Не } & 34 & 57,6 \%\end{array}$

Табела 5.2

Најголемиот дел од испитаниците (70,5\%) подготвуваат термички обработена храна еднаш дневно и ги користат активно апаратите од 30 до 90 минути (71,7\%). 
Периодот од текот на денот во кој ова најчесто се прави е помеѓу 12 и 18h (

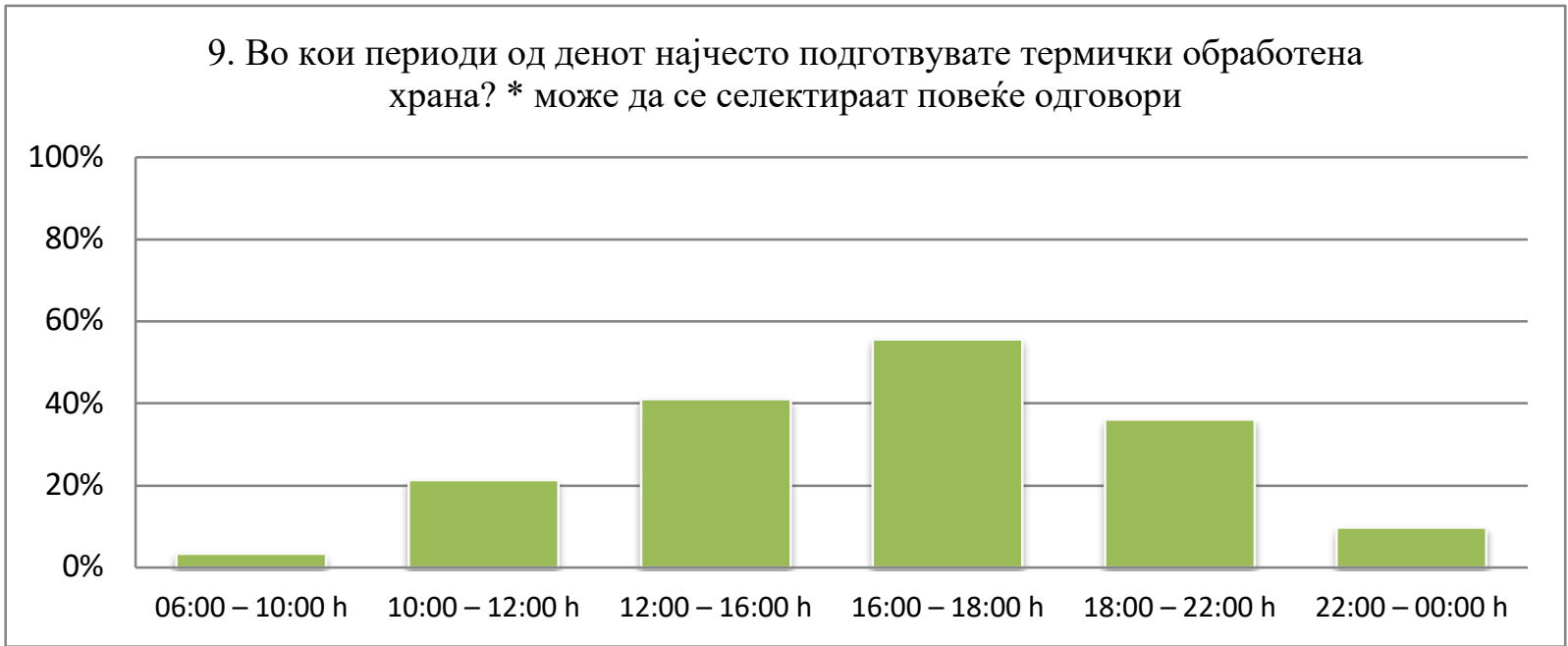

Графикон 5.3). Токму овие податоци ни даваат до знаење дека при долги сончеви денови, особено во летниот период концептот на соларен шпорет ќе може успешно да се вклопи во веќе постоечките секојдневни навики на потрошувачите.

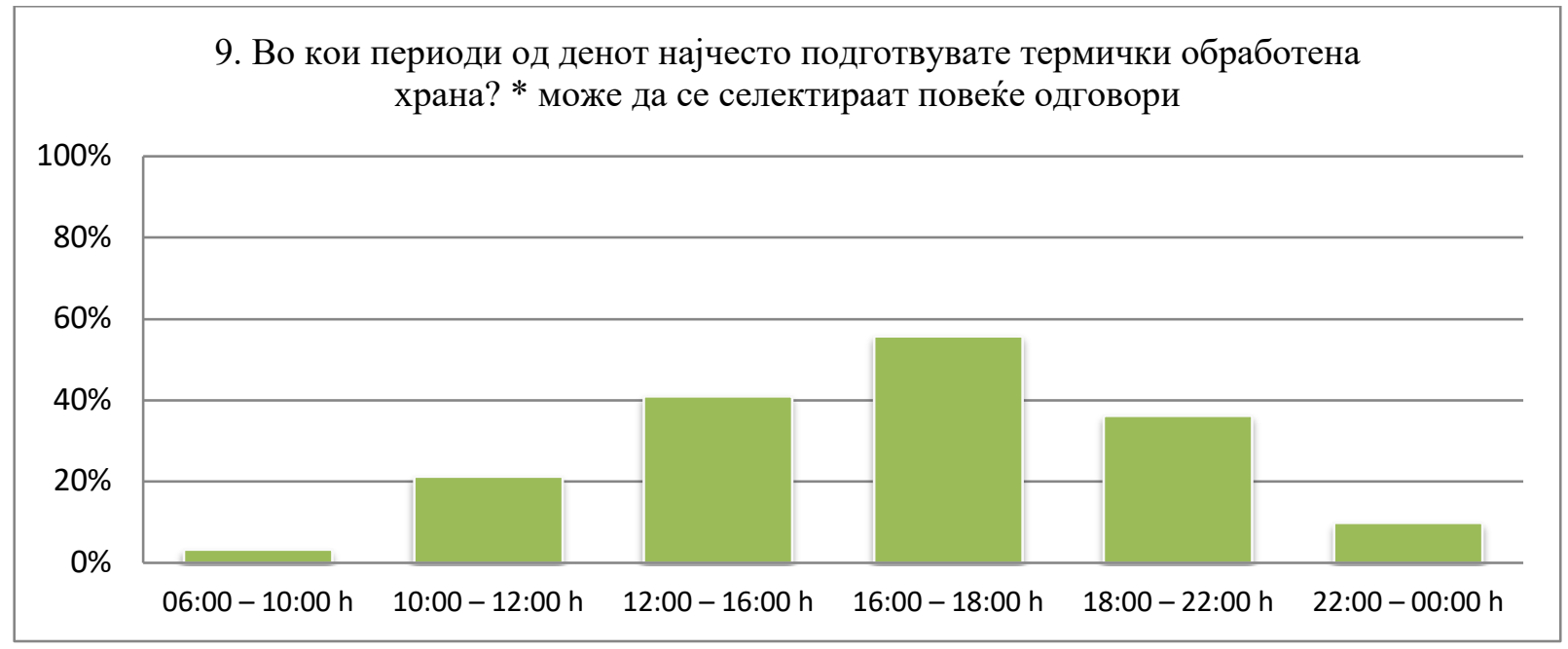

Графикон 5.3

9. Во кои периоди од денот најчесто подготвувате термички обработена храна? * може да се селектираат повеќе одговори

Одговор

Број на Процент \%

испитаници 


$\begin{array}{lrr}06: 00-10: 00 h & 2 & 3,3 \% \\ 10: 00-12: 00 h & 13 & 21,3 \% \\ 12: 00-16: 00 h & 25 & 41 \% \\ 16: 00-18: 00 h & 34 & 55,7 \% \\ 18: 00-22: 00 h & 22 & 36,1 \% \\ 22: 00-00: 00 h & 6 & 9,8 \% \\ 00: 00-06: 00 h & 0 & 0 \%\end{array}$

Табела 5.3

Она што не оди во прилог е тоа што само 39,3\% сакаат да готват на отворено и тоа обично се сведува на неколку пати во годината (Графикон 5.4 и Графикон 5.5). Тоа е така бидејќи обично се поврзува со правење на скара во природа при излет или кампување, но готвење на отворено не треба да подразбира само тоа, туку тоа може да се одвива секојдневно на балконот од домот или во дворот, при што храната може термички да се обработува исто како и кај традиционалните уреди.

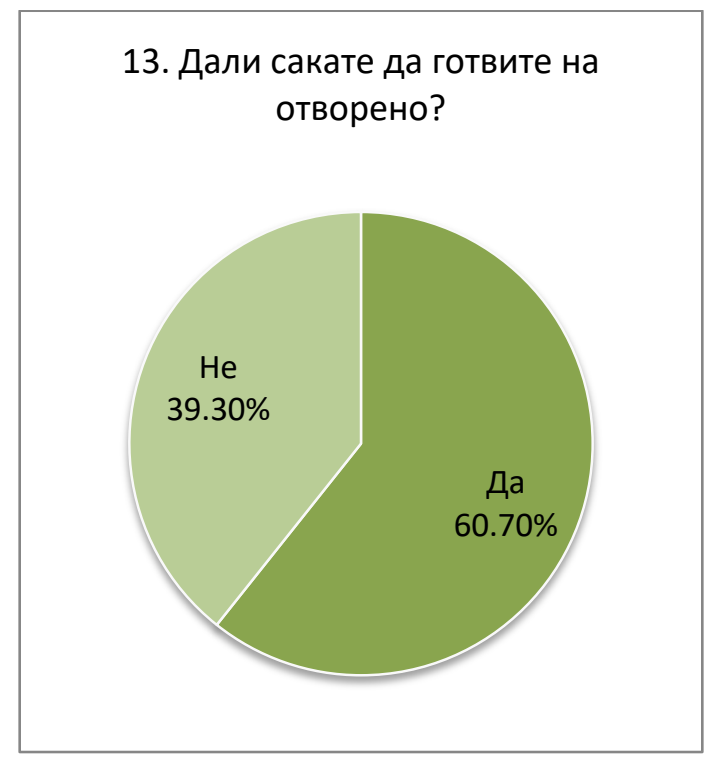

Графикон 5.4

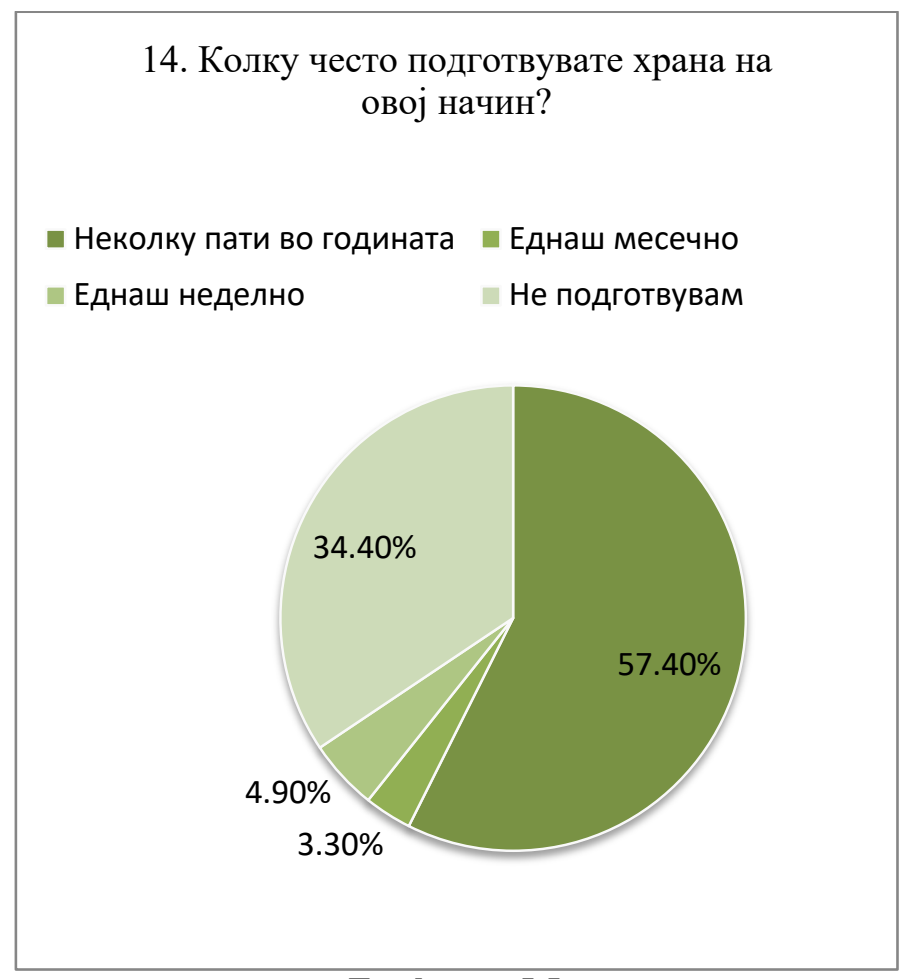

Графикон 5.5

13. Дали сакате да готвите на отворено? 14. Колку често подготвувате храна на овој начин? 


\begin{tabular}{|lrr|lrr|} 
Одговор & $\begin{array}{r}\text { Број на } \\
\text { испитаници }\end{array}$ & $\begin{array}{r}\text { Процент } \\
\%\end{array}$ & Одговор & $\begin{array}{r}\text { Број на } \\
\text { испитаници }\end{array}$ & $\begin{array}{r}\text { Процент } \\
\%\end{array}$ \\
\hline Да & 37 & $60,7 \%$ & Неколку пати во годината & 35 & $57,4 \%$ \\
Не & 24 & $39,3 \%$ & Еднаш месечно & 2 & $3,3 \%$ \\
& Табела 5.4 & & Еднаш неделно & 3 & $4,9 \%$ \\
& & & Не подготвувам & 21 & $34,4 \%$
\end{tabular}

Иако запознаеноста на испитаниците со концептот на соларен шпорет не е многу голема, тоа што охрабрува е податокот дека нивната еколошка свест е на доста високо ниво и доколку би знаеле дека со одредени постапки ја зачувуваат животната средина истите би ги примениле.

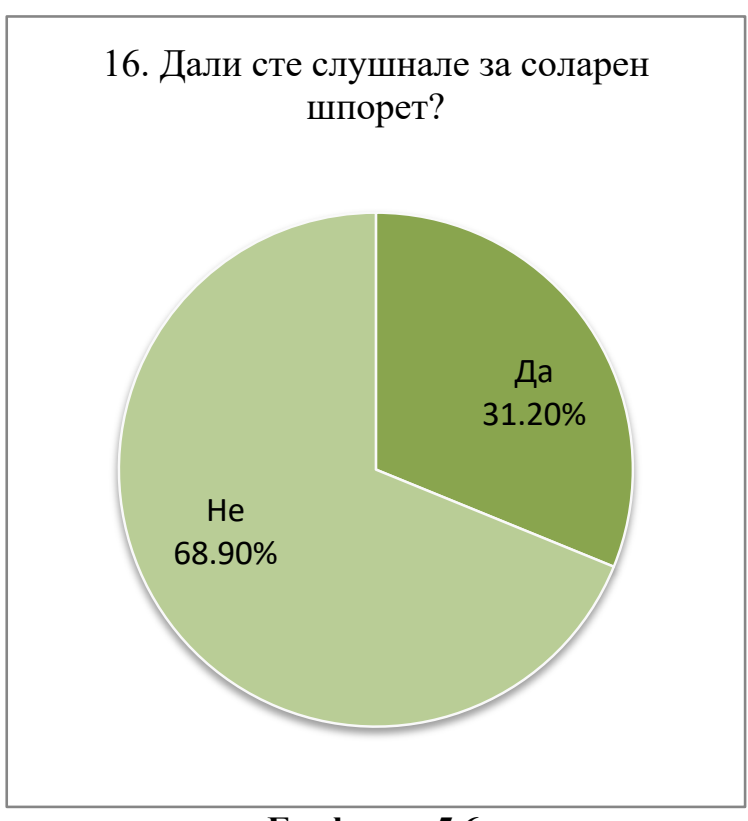

Графикон 5.6

16. Дали сте слушнале за соларен шпорет?

$$
\text { Одговор }
$$

Број на

Процент
18. Дали би користеле соларен шпорет ако знаете дека со тоа ја зачувувате животната средина?

$$
\mathrm{He}
$$

$3.30 \%$

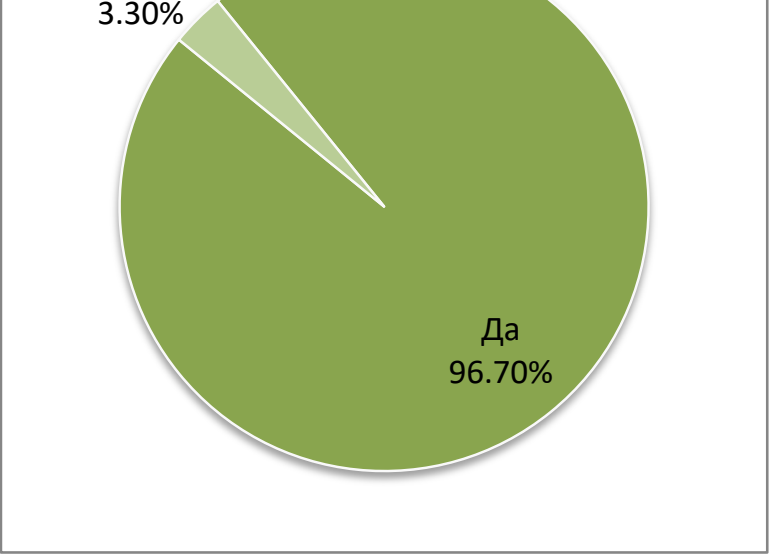

Графикон 5.7

18. Дали би користеле соларен шпорет ако знаете дека со тоа ја зачувувате животната средина? Одговор 


$\begin{array}{ccccccc}\text { Да } & 19 & 31,2 \% & & \text { испитаници } & \text { \% } \\ \text { Не } & 42 & 68,9 \% & \text { Да } & 59 & 96,7 \% \\ & \text { Табела 5.6 } & & & \text { Не } & 2 & 3,3 \%\end{array}$

Табела 5.7

\section{1 Листа на карактеристики и инженерски спецификации}

Постојат повеќе методи за генерирање на инженерски спецификации. Една од најдобрите и најпопуларните методи е наречена „Развој на функција на квалитет” (Quality Function Development). Со примена на овој метод кој е фундаментален при креирање и планирање на нов производ, информациите се организираат во неколку поврзани матрици кои заедно се нарекуваат „Куќа на квалитет“ (Нouse of Quality). Во овој дел се врши анализа на барањата на сите целни групи, споредба со особините на конкурентските производи, за на крај целите на новиот производ да бидат преточени во мерливи инженерски спецификации (Error! Reference source not found. и Error! Reference source not found.) 
[ПРИМЕНА НА БИОНИЧКА МЕТОДОЛОГИЈА ЗА ГЕНЕРИРАЊЕ НА КОНЦЕПТИ]

\begin{tabular}{|c|c|c|c|c|c|c|c|c|c|c|c|c|c|c|c|c|c|c|c|c|c|}
\hline \multicolumn{22}{|l|}{ иәлоџЧ } \\
\hline \multicolumn{22}{|l|}{$00 乙$ dกуооЈ 乙 $\Perp$ нәдКяноч } \\
\hline \multicolumn{22}{|l|}{ 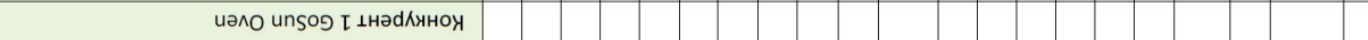 } \\
\hline \multicolumn{22}{|l|}{ 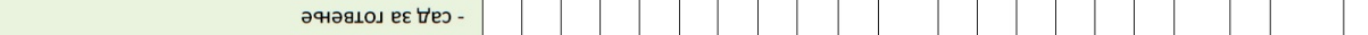 } \\
\hline \multicolumn{22}{|l|}{ енитdяоu еяhеdицяәгфәd ен - } \\
\hline \multicolumn{22}{|l|}{ 上онтпдовътен ен - } \\
\hline \multicolumn{22}{|l|}{ иurẹ̣dəıеw } \\
\hline 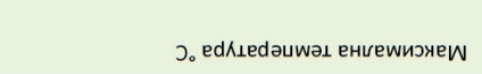 & & & & & & & & & & & & & & & & & & $\begin{array}{l}0 \\
\infty \\
\infty \\
\infty \\
\infty\end{array}$ & \begin{tabular}{l}
0 \\
0 \\
8 \\
0 \\
\hdashline
\end{tabular} & & \\
\hline \multicolumn{22}{|l|}{ 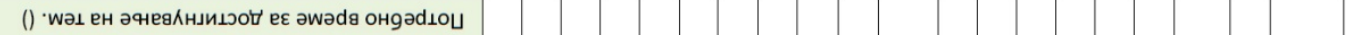 } \\
\hline 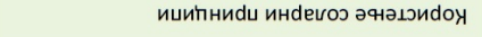 & & & & & & & & & & & & & & & & & & 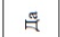 & ต & ㅁ & \\
\hline 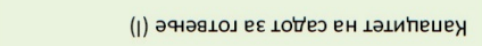 & & & & & & & & & & & & & & & & & & $\stackrel{0}{-}$ & & $\stackrel{2}{-}$ & \\
\hline \multicolumn{22}{|l|}{ 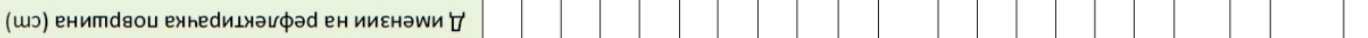 } \\
\hline (щว) $\perp$ douวнеd $\perp$ й ииєнәши $\square$ & & & & & & & & & & & & & & & & & & $\frac{\stackrel{2}{x}}{\sigma} \frac{m}{x}$ & & 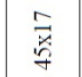 & \\
\hline (шว) еgжочоч енәчогжәед ов ииєнәшй & & & & & & & & & & & & & & & & & & & 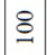 & 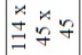 & \\
\hline (еwdoф) енитdяou еянеdицяәгфәd ен Ұия & & & & & & & & & & & & & & & & & & घ & E & E & \\
\hline 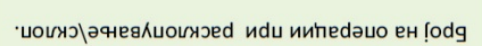 & & & & & & & & & & & & & & & & & & ćt & ণ & $m$ & \\
\hline \multicolumn{22}{|l|}{ 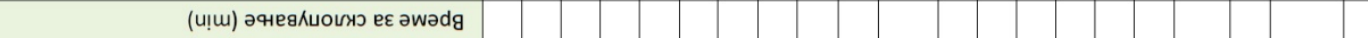 } \\
\hline 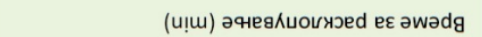 & & & & & & & & & & & & & & & & & & & 으 & & \\
\hline (\$) енәП & & & & & & & & & & & & & & & & & & ڤે & 造 & $\stackrel{\mathscr{\Xi}}{\Xi}$ & \\
\hline \multicolumn{22}{|l|}{ (8у) енижәц } \\
\hline \multicolumn{22}{|l|}{ ииһеяифићәчว ияวdәнәжни } \\
\hline чәџиҢовєиоди & $\exists$ & -1 & a & 6 & $\approx$ & $\stackrel{\leftrightarrow}{\rightarrow}$ & $\stackrel{n}{\sim}$ & n & $r$ & $\infty$ & 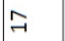 & + & A & 욱 & $\stackrel{m}{\rightarrow}$ & $\sim$ & $m$ & & & & \\
\hline доциКцэноя & $n$ & 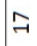 & -1 & N & $m$ & 욱 & $\exists$ & 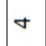 & in & 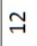 & $\stackrel{\varphi}{\sim}$ & a & $\stackrel{m}{\rightarrow}$ & $\stackrel{n}{\sim}$ & I & $\bullet$ & $\infty$ & & & & \\
\hline hegКบКн & 省 & $\sim$ & $\wedge$ & $m$ & $\infty$ & $\stackrel{\sim}{\sim}$ & $\stackrel{9}{\rightarrow}$ & in & $\bullet$ & 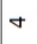 & $\exists$ & -1 & a & $\exists$ & 윽 & $\approx$ & $\stackrel{m}{\rightarrow}$ & & & & \\
\hline \multicolumn{22}{|l|}{ ићинецичวи ен әяәљวй } \\
\hline 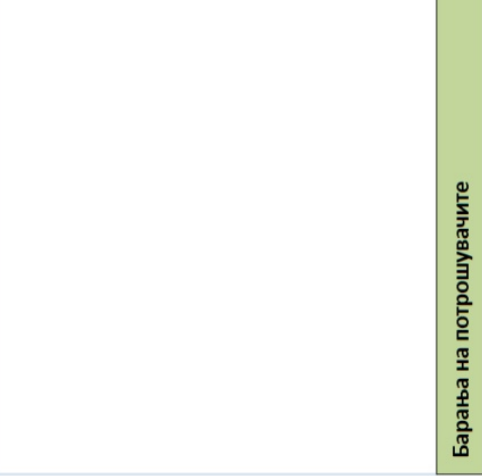 & 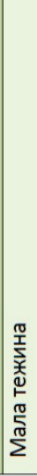 & 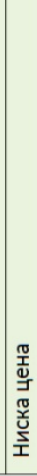 & 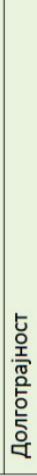 & 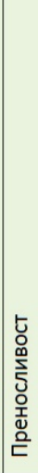 & 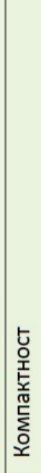 & 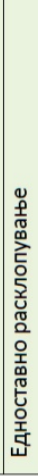 & 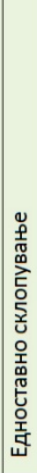 & 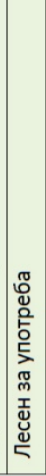 & 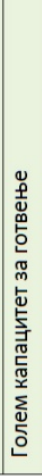 & 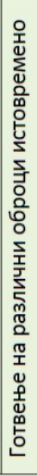 & 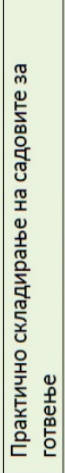 & 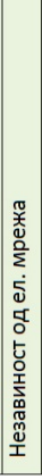 & 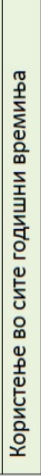 & 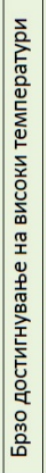 & 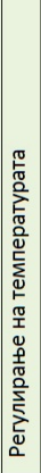 & 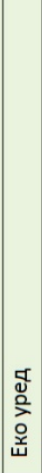 & 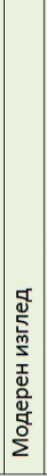 & 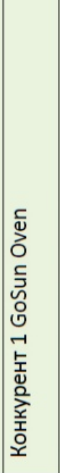 & 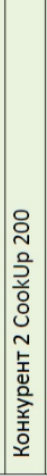 & 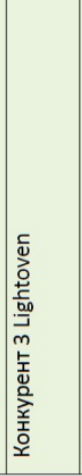 & \\
\hline
\end{tabular}




\section{Листа на барања:}

- Мала тежина

- Ниска цена

- Долготрајност

- Преносливост

- Компактност

- Едноставно расклопување

- Едноставно склопување

- Лесен за употреба

- Голем капацитет за готвење

- Готвење на различни оброци истовремено

- Практично складирање на садовите за готвење

- Незавиност од електричната мрежа

- Брзо достигнување на високи температури

- Регулирање на температурата

- Еко уред

- Модерен изглед 


\section{6. Примена на бионичка методологија за генерирање на концепти}

Дизајн методологиите се основни алатки во процесот на дизајнирање кои обезбедуваат насоки, цели и технички упатства за развој на еден производ ${ }^{41}$. Биониката пак е интердисциплинарна област која бара инспирација во природата за да обезбеди решенија за дизајнерски и инженерски проблеми во различни области и различни гранки на индустријата, како што се: дизајн, биоинженеринг, аеронаутика, науката за вселената и биоматеријалите ${ }^{42}$. Нејзината примена се движи од емоционален пренос на форма до користење на функционалните принципи.

Постојат два главни приоди во бионичкиот дизајн ${ }^{43}$ :

- одгоре - надолу, кој започнува со технички проблем, а решението се бара во природните системи, и

- оддолу - нагоре, пристап кој започнува со биолошки феномен и се пренесува на потенцијално техничко решение.

За овој магистерски труд ќе биде искористена методологија за бионички дизајн предложена од Carlos A.M.Versos u Denis A.Coelho прикажана во Табела 6.1 каде истата е разработена по чекори и развиена во правец „од дизајн проблем до бионичко решение“.

\begin{tabular}{|ll} 
Чекори & Објаснување \\
\hline Информации за & - Спецификација на проблемот што треба да се реши со \\
дизајнот и дефинирање & идентификување на функциите кои тој мора да ги \\
на проблемот & извршува, посакуваните барања и органичувања. \\
& - Изработка на шематска листа на барањата и клучните \\
\hline
\end{tabular}

\footnotetext{
${ }^{41}$ A Bi-Directional Method for Bionic Design with Examples, Carlos A. M. Versos and Denis A. Coelho

42 Bionic Design in Industrial Desing. Education at University of Tehran - Jamshid Emami, Mahshid Tashakori and Zahra Tashakorina

${ }^{43}$ Bionics in Engineering-Defining new Goals in Engineering. Education at "Polytehnica" University of Bucharest Neurohr, R., Dragomirescu, C.
} 


\begin{tabular}{|c|c|}
\hline & еколошки аспекти. \\
\hline $\begin{array}{l}\text { Реформулација на } \\
\text { проблемот }\end{array}$ & $\begin{array}{l}\text { - Ревизија и редефинирање на општите проблеми и задачи, } \\
\text { дефинирани во биолошка терминологија. } \\
\text { - Испитување како природата ги решава проблемите или } \\
\text { функциите кои треба да се решат во дизајн процесот. }\end{array}$ \\
\hline Избор на решенија & $\begin{array}{l}\text { - Барање на биолошки модели и решенија преку } \\
\text { литературни пребарувања, теренски набљудувања или } \\
\text { користење на отворени дискусии со биолози и експерти. }\end{array}$ \\
\hline Анализа на решенијата & $\begin{array}{l}\text { - Идентификација и морфолошка анализа на структури, } \\
\text { компоненти, процеси и функции на биолошкото решение } \\
\text { - Поврзување на функциите и барањата на проблемот со } \\
\text { функциите и карактеристиките на биолошкото } \\
\text { решение. }\end{array}$ \\
\hline $\begin{array}{l}\text { Генерирање на } \\
\text { концепти }\end{array}$ & $\begin{array}{l}\text { - Развој на идеи и концепти (во форма на скици и 3D } \\
\text { модели) и следење на насоките и принципите усвоени во } \\
\text { чекорите на анализа и дефинирање на биолошкото } \\
\text { решение за проблемот. }\end{array}$ \\
\hline Потврдување & $\begin{array}{l}\text { - Верификација на усогласеноста на барањата од } \\
\text { проблемот и придобивките воведени преку бионичкиот } \\
\text { концепт. } \\
\text { - Избор на најсоодветен концепт за следниот чекор }\end{array}$ \\
\hline Детали и завршна & $\begin{array}{l}\text { - Изработка на технички цртежи за производство, детални } \\
\text { описи на компоненти, материјали, производствени } \\
\text { процеси и сите разгледувања соодветни на видот и } \\
\text { намената на проектот. } \\
\text { - Изработка на прототип и презентација на резултатите. }\end{array}$ \\
\hline
\end{tabular}

Табела 6.1 Краток опис на чекорите на методот за развој на бионички дизајн - во насока од дизајн проблем до бионичко решение 


\section{1 Дефинирање на проблемот}

Проблемите кои се јавуваат кај уредите за готвење на соларна енергија се однесуваат пред се́ на нивното функционирање, кое е можно само при изложеност на сончева енергија. Токму поради тоа потребно е дизајнерско решение кое ќе обезбеди максимално ефикасно искористување на сончевите периоди. Покрај независноста од ел. мрежа која ја нуди (6), овој уред треба да биде компактен (1) и лесно пренослив (2)(3), а со тоа атрактивен за користење во дворот или на кампување. Додека се наоѓa во функција потребно е да има голема површина (4) која ќе ги рефлектира сончевите зраци, а потоа истата таа да може да се собере и со тоа да се задржи компактноста на дизајнот. Просторот во зоната за подготовка на храна треба да биде поделен (5) и со тоа да се овозможи припрема на различни оброци истовремено. Потребно е и место за складирање (7) на садовите и можност за придвижување на рефлектирачката површина (9). Обединувањето на сите овие решенија во еден уред треба да ја зголеми искористеност во секојдневието со што во сончевите периоди би претставувал одлична алтернатива на конвенционалните уреди за готвење.

\begin{tabular}{|c|c|}
\hline Проектни барања & Цели \\
\hline 1) Компактност & -облик \\
\hline 2) Преносливост & - оптимизрање на облик \\
\hline 3) Мала тежина & - материјали \\
\hline 4) Голема рефлектирачка површина & - материјали и облик \\
\hline 5) Поделба на просторот за готвење & - економичен облик \\
\hline 6) Самостојно функционирање & -технологија \\
\hline 7) Простор за скаладирање & -Економичен облик \\
\hline 8) Регулирање на температура & -Ефикасност на технологија \\
\hline 9) Механизам за придвижување & -Технологија \\
\hline 10) Постигнување на високи температури & -Материјали, облик \\
\hline 11) Привлечна форма & - Облик \\
\hline
\end{tabular}

Табела 6.2 Листа на барања и цели кои треба да се постигнат 


\section{2 Преформулирање на проблемот}

За да се олесни процесот на потрага по биолошки решенија во природата кои ги исполнуваат барањата на проблемот, следен чекор е да се ревидираат функциите изнесени во проектните барања во поглед на функции во природата.

\begin{tabular}{|ll|}
\hline Барања & Реформулација на барањата во однос на функции во \\
\hline Голема рефлектирачка & природата \\
површина и компактност на & развлекување на една иста форма \\
форма & \\
\hline Мала тежина и преносливост & - форма од природата која е лесна, но доволно цврста \\
\hline Поделба на просторот за & - решение од природата кое овозможува максимлано \\
готвење и за складирање & и ефикасно искористување на мал простор со \\
& групирање, организирање или поделба \\
\hline Можност за придвижување & - решение од природата кое овозможува \\
\hline
\end{tabular}

Табела 6.3 Преформулирање на проектните барања во однос на карактеристики и функции изведени во природата

\section{3 Избор на решенија од природата}

По ревидирањето на барањата за функции и карактеристики присутни во природата, направено е бионичко истражување преку кое се обидов да пронајдам најдобри решенија кои можат да дадат одговор на претходно дефинираните барања.

Во однос на барањето кое се однесува на голема рефлектирачка површина, а истовремено и компактност на истата, во природата постојат повеќе решенија. Меѓу нив се крилјата на инсектите, структури кои значително го менуваат обликот и големината, потоа обликот на многуногите членконоги кои се карактеризираат со сегементиран надворешен скелет кој при движење се собира и потоа повторно растегнува, како и животинки од видот на армадилото и ежот кои имаат флексибилен економичен облик кој во дадени ситуации им овозможува намалување на нивната површина преку свиткување 
во форма на топка. Кај растителниот свет инспирација за компактен облик се лисјата кои имаат различни начини на виткање и превиткување.

Економичноста на површината и просторот ја сретнуваме кај хексагоналните структури кои ги градат пчелите, а се извондредно силни и лесни. Исто така, зрнестите мешункасти култури се пример за начин на групирање и максимално искористување на мал простор.

Можност за придвижување во насока на светлината природата применила кај некои растенија меѓу кои и сончогледот. Оваа појава е позната како хелиотропизам.

\section{4 Анализа на решенијата}

Овој чекор опфаќа анализа на структурите, процесите и функциите на претходно изнесените бионички решенија со цел подобро разбирање, поврзување и изнаоѓање на најсоодветно решение од природата за претходно дефинираниот проблем и проектни барања.

\subsection{1 Намалување на површина}

Многу суштества ја препознаваат вредноста за поседување на најмала можна површина. Завивањето во топка е едноставна, но ефективна форма на одбрана што ја користат разни животинки за намалување на нивната површина.

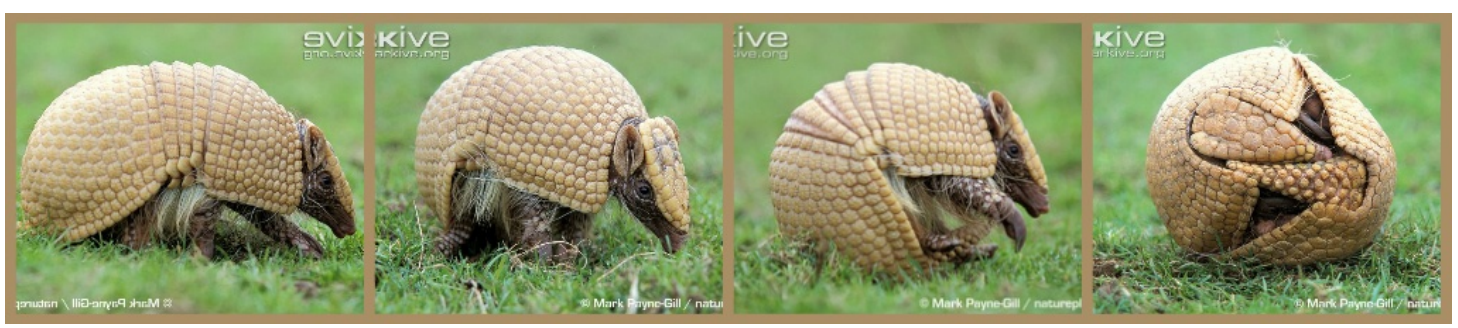

Слика 6.1 Армадило (armadillo) се штити себеси од предатори со намалување на својата површина преку свиткување во топка

Економичноста на обликот е направена уште поефикасна со додавање на флексибилност на површината од сферата. Таков е примерот со армадилото прикажан на Слика 6.1. Сите ранливи и витални органи како и екстремитетите се свиткуваат далеку во 
внатрешноста на заштитната обвивка. Слични примери може да видиме и кај многуногите членконоги кои се карактеризираат со сегментиран надворешен скелет (Слика 6.3), како и кај ежот, добро позната животинка во нашите краишта (Слика 6.2).

Идејата за ваквото намалување на површината може да се искористи на многу различни начини во дизајнот. Собирањето на површината при опасност е одлична идеја за примена кај системите на обновлива енергија кога постои закана од бура и сл.

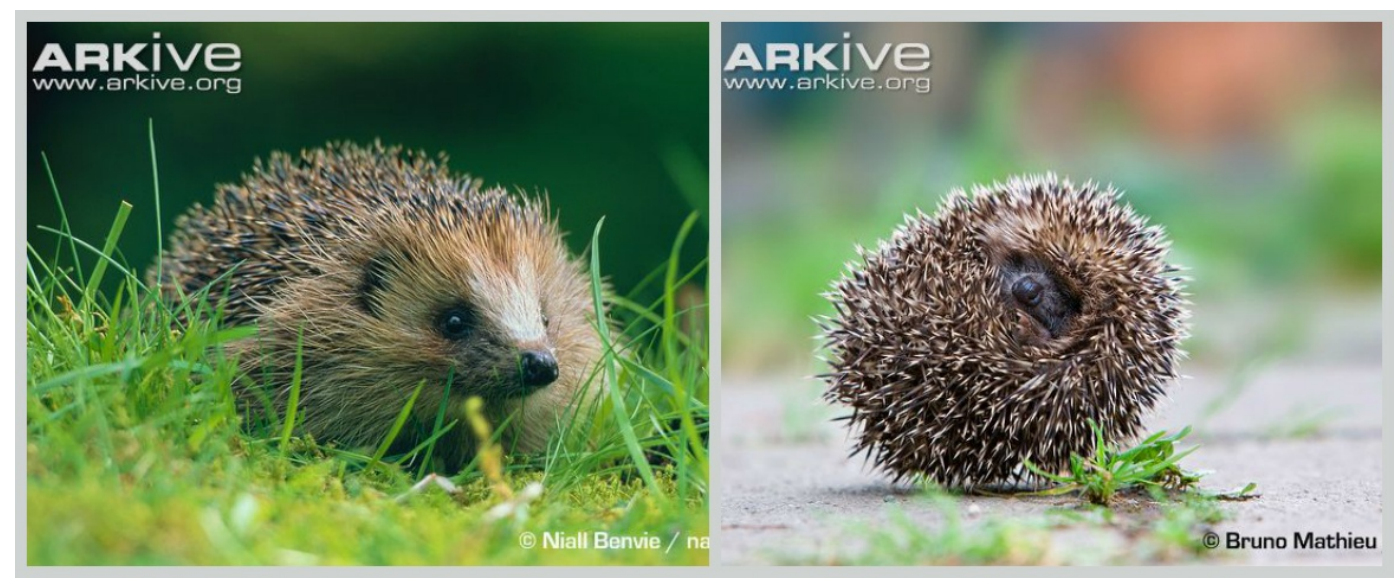

Слика 6.2 Еж свиткан во форма на одбрана (топка)

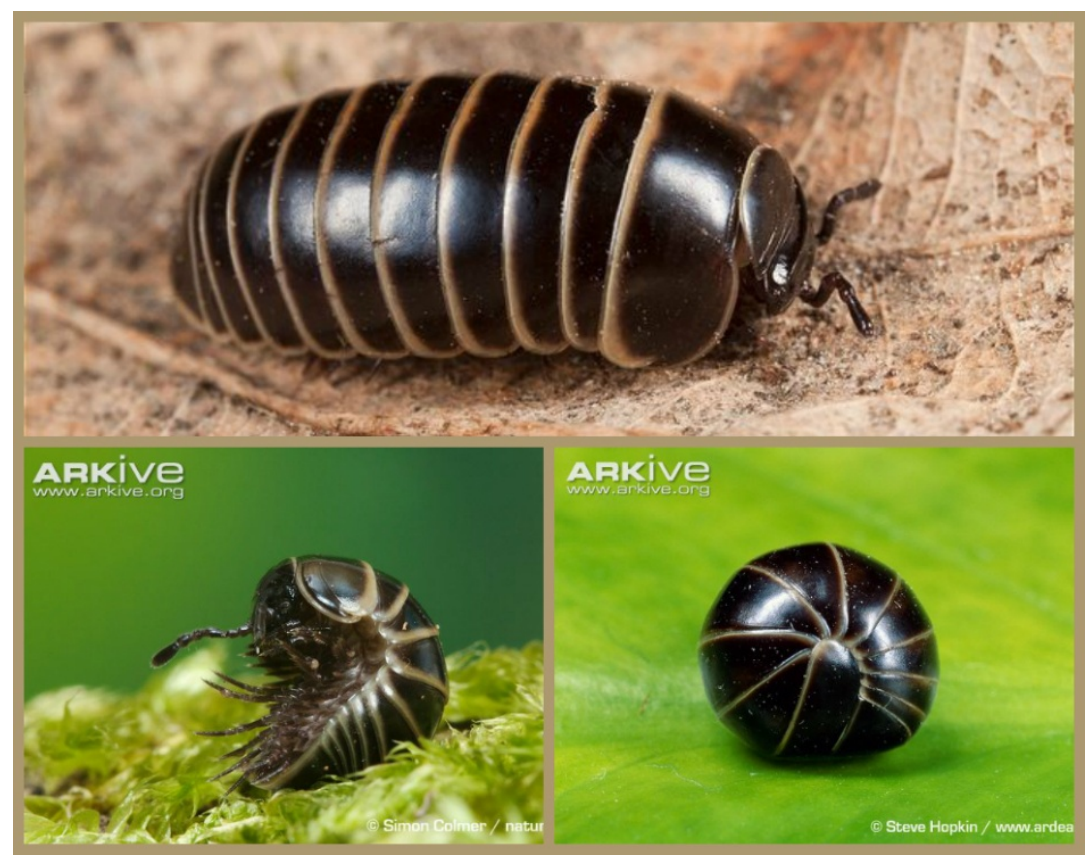

Слика 6.3 Надворешниот скелет од сегменти кај pill millipede е поврзан на начин кој овозможува лесно смотување во топка 


\subsection{2 Комплексни структури кои фокусираат рефлектирана светлина}

Окото на јастогот ја фокусира рефлектираната светлина врз мрежницата со користење на совршена геометриска конфигурација од квадратни цевки. Тој функционира на принципот на рефлексија, наместо рефркација. Најзначајна карактеристика е неговата површина, која е составена од бројни квадрати правилно позиционирани. Добро позиционираните квадрати всушност се страни на мали квадратни цевки кои формираат структура во форма слична на саќе. На прв поглед се чини дека саќето е составено од шестоаголници, иако тоа всушност се предни страни на шестострани призми. Кај окото на јастогот наместо шестоаголници се појавуваат квадрати.

Уште поинтересно е тоа што секоја од страните на овие квадратни цевки се однесува како огледало кое ја рефлектира влезната светлина. Рефлектираната светлина се фокусира врз мрежницата беспрекорно. Страните на цевките во внатрешноста на окото се подредени под совршени агли така што сите тие ја фокусираат светлината врз една единствена точка. Сосема неспорна е извонредната природа на дизајнот на овој систем.

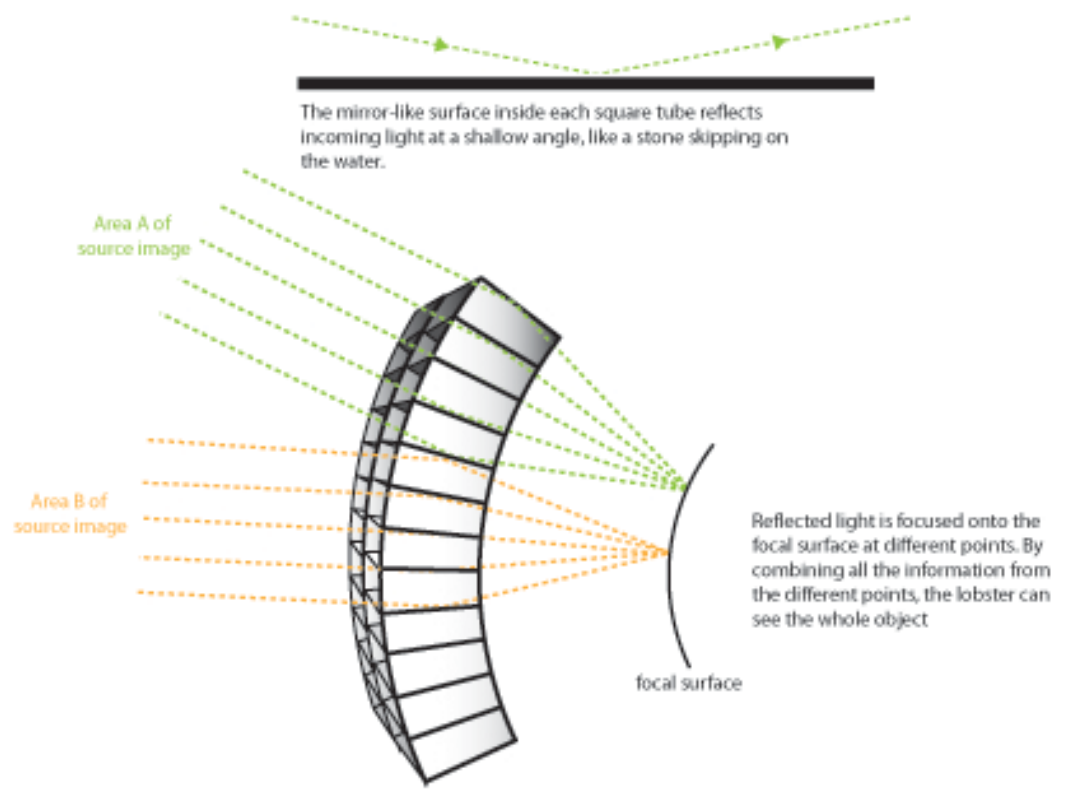

Слика 6.4 Структура на окото на јастог. Рефлектираната светлина се насочува кон фокалната површината во различни точки. Со комбинирање на информациите од различните точки, окото може да го види целиот објект 


\subsection{3 Структури кои го менуваат обликот со значителна промена на својата големина}

Инсектите ги користат своите крилја за различни намени. Тврдокрилните инсекти (лат. Coleoptera) поминуваат голем дел од своето време на земја, пробивајќи се низ остатоците од зеленчук, гребејќи во почвата или глодајќи во дрвјата. Ваквите активности лесно може да ги оштетат нивните нежни крилја. Поради тоа предните крилја обрзувале цврсти заштитни покрилци под кои вешто се собрани задните крила кога инсектот не лета. Кога заштитните покрилци ќе се подигнат, крилјата се активираат и отвораат. Кога тврдокрилниот инсект се наоѓa во воздух крилните капаци обично се држат на страна, положба која овозможува и не ја попречува ефикасноста на летот. Исто така тие се виткаат повеќекратно без абење и замор.

Оваа појава од природата проследена преку примерите на Coccinella septempunctata (Слика 6.5) и Leptinotarsa decemlineata (Слика 6.6) може да се искористи при дизајнирање на расклопливи структури кои имаат потреба од поголем број пати на склопување и расклопување со минимално зафаќање на простор.

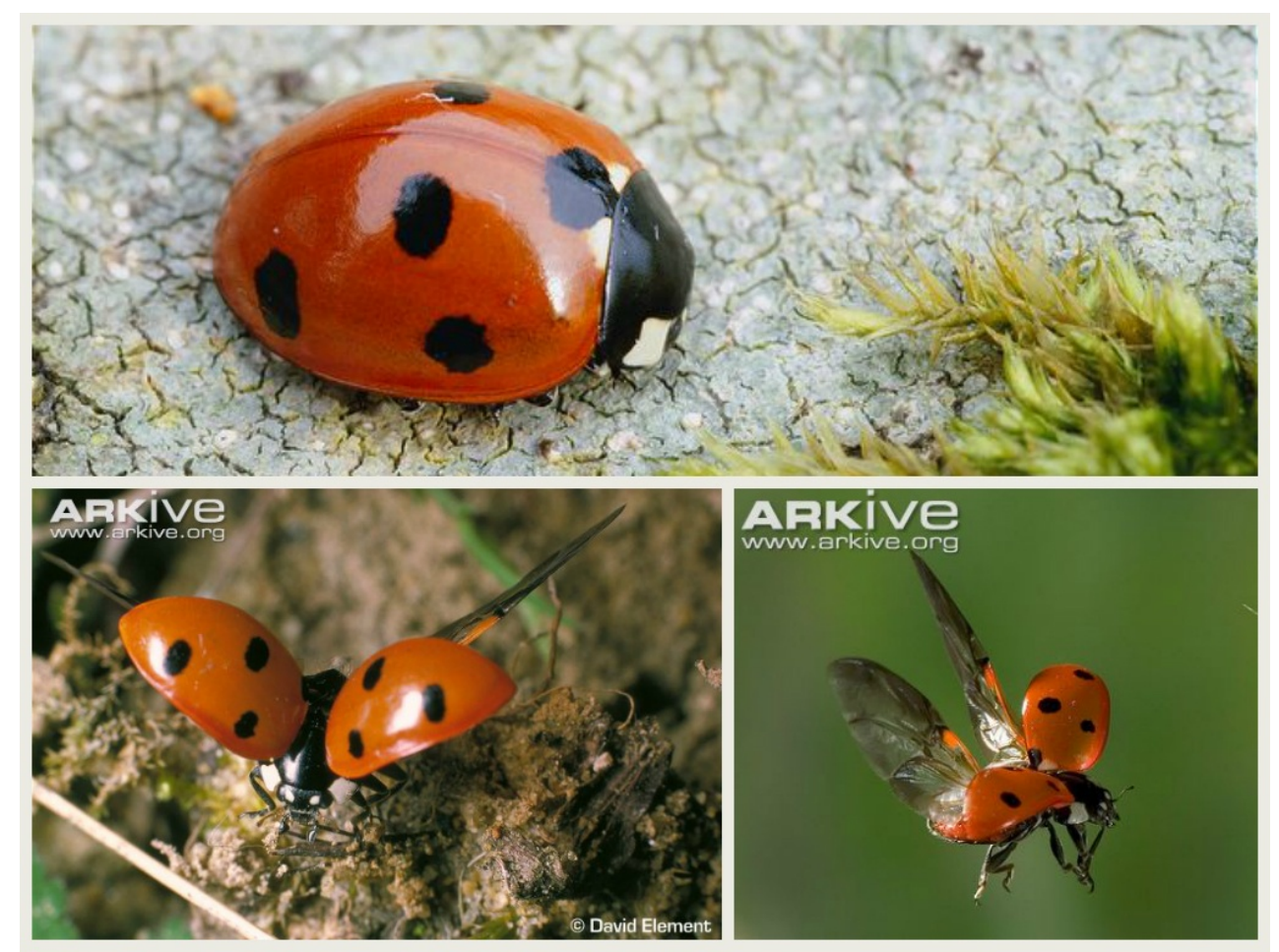

Слика 6.5 Coccinella septempunctata - бубамара со седум карактеристични точки 

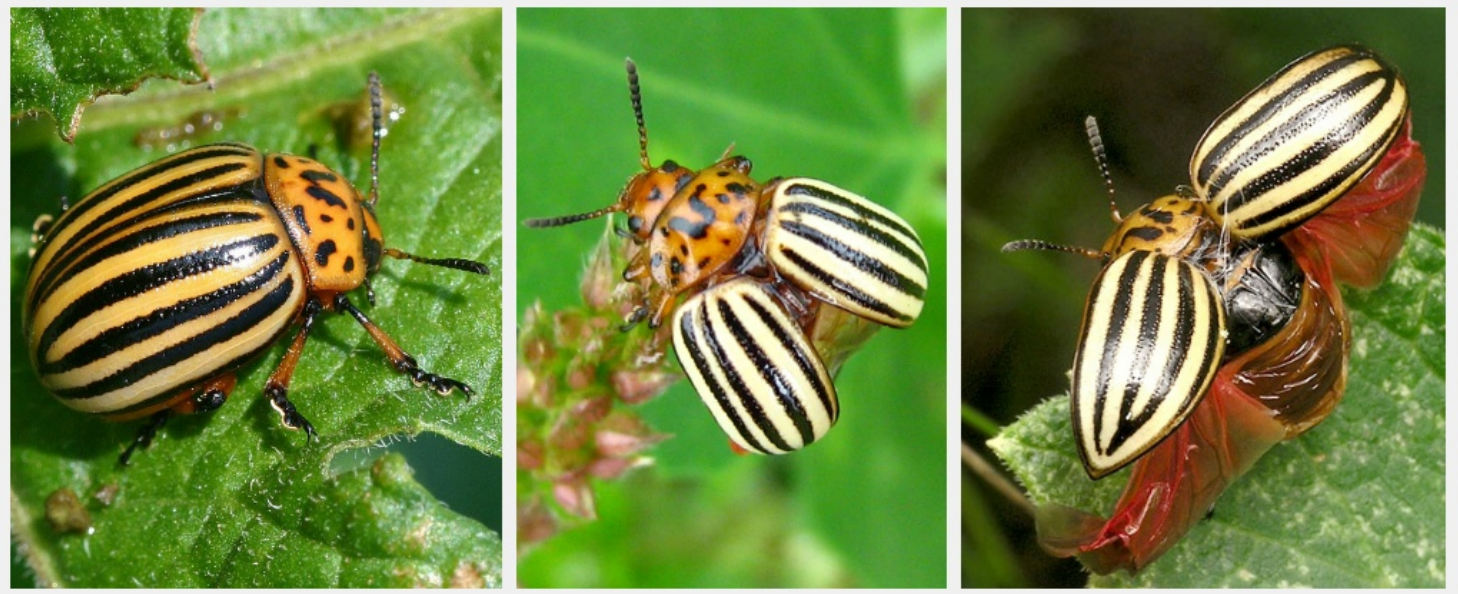

Слика 6.6 Компирова златица (лат. Leptinotarsa decemlineata)

Крилјата на пеперутките покрај тоа што може да се виткаат повеќекратно, исто така служат и како рефлектори. Со нивно делумно отворање ја фокусираат сончевата светлина на градниот кош каде всушност се прицврстени мускулите од нивните крилја. Ако времето е премногу топло тогаш ги преклопуваат крилјата и ги позицонираат на средина, вертикално, така да сонцето удира само на работ од крилјата. Но кога сонцето не обезбедува доволно топлина за движење, тогаш пеперутките ги придвижуваат крилјата во мали интервали во секоја насока, со што постепено ги затоплуваат мускулите. Во премногу ладни услови не може воопшто да се движат.
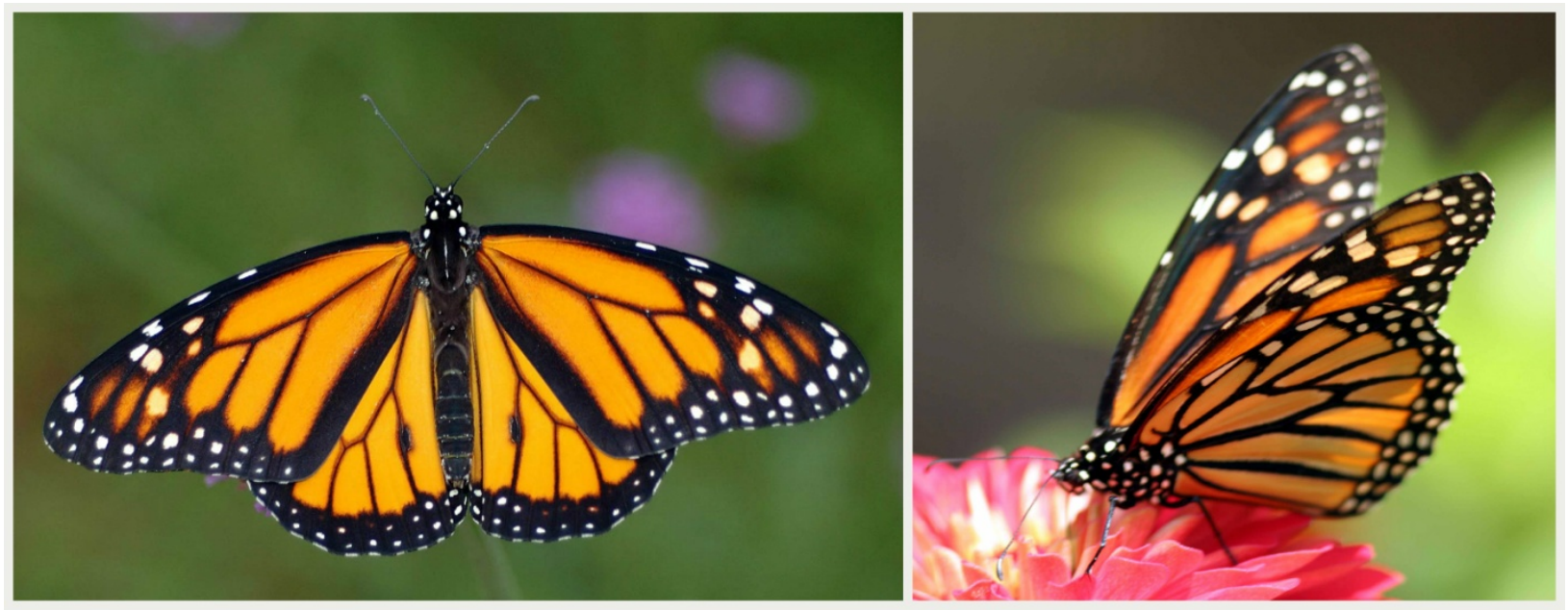

Слика 6.7 Крилјата на пеперутките имаат и функција да ја рефлектираат сончевата светлина 


\subsection{4 Компактен облик кај растенијата}

Многу години растенијата претставуваат богат извор на информации во областа на дизајнирањето и оптимизирање на материјалите. Чичекот (лат. Arctium lappa) има директно влијание врз пронајдокот на велкро системот за закачување, додека лотусовиот лист е инспирација за многу хидрофобни површини. Еластичниот одговор на растенијата кога се изложени на надворешните дразби како вода, светлина итн. е прилично интерсен и со голем број на можности истите да се искористат во пракса.

Лисјата на растенијата го зголемуваат времето на изложување на фотосинтеза преку користење на различни начини на виткање и превиткување кои овозможуваат брзо и ефикасно одвиткување и започнување со процесот.

Лисјата на повеќето растенија се преклопени или завиткани додека сеуште се наоѓаат во внатрешноста на пупката. Тие излегуваат од нив на многу различни начини. Оние на монстерата (лат. Monstera Deliciosa) [билка со големи темнозелени листови кои се длабоко изрежани и шупливи во средината] се појавуваат цврсто завиткани, како совршено собрани чадори. Лисјата на палмите пак се уредно набрани. Големите дебели пупки на рабарбарата (лат. Rheum rhabarbarum) [повеќегодишно растение со големи листови и зеленикаво до црвено стебло што се користи за правење компот или како лековито растение] кога ќе изникнат од земја ги покажуваат своите младите листови кои се сплескани и изгужвани. Кај папратите новите лисја се појавуваат со одвиткување на една тенка спирала (свиткана во форма на полжав), а на секоја страна од спиралата лисјата се повторно свиткани во минијатурна форма на полжав.

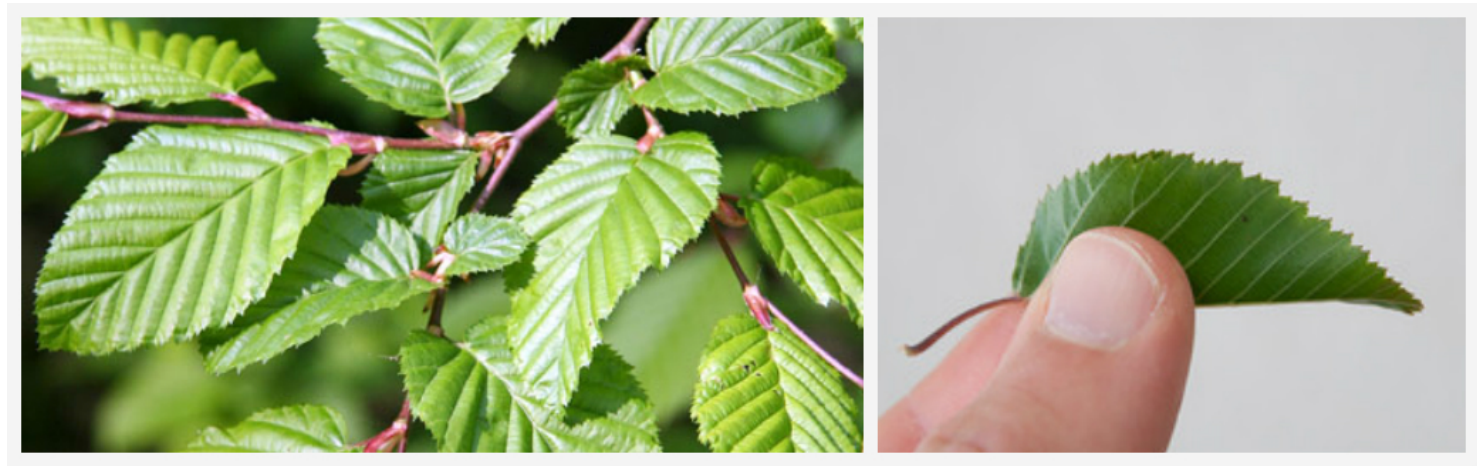

Слика 6.8 Листот од габер има брановидна шема на виткање 

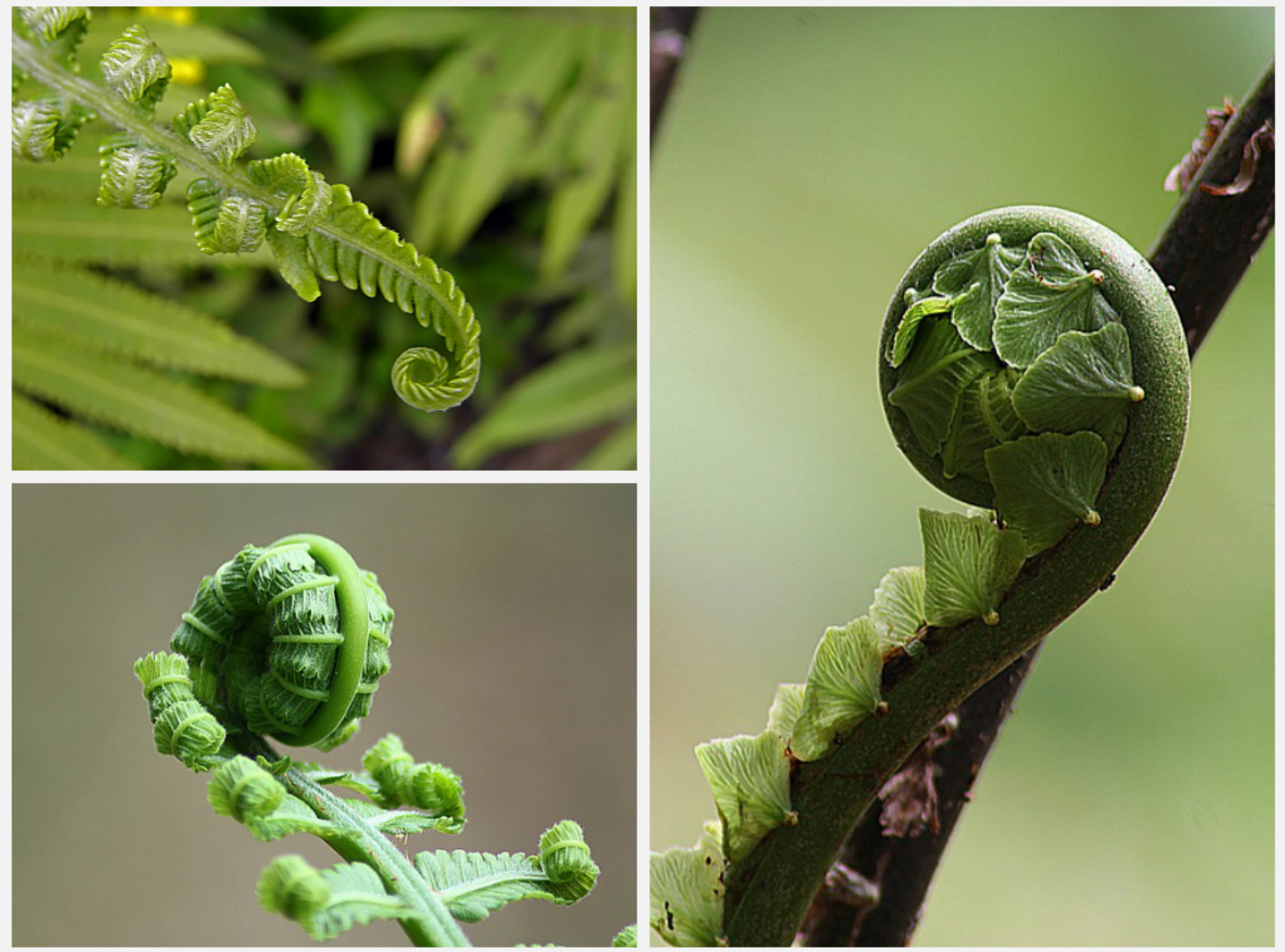

Слика 6.9 Лисја од папрати свиткани во форма на полжав

Лисјата на габер и бука се заштитени во внатрешноста на пупките со компактно превиткување, со релативно едноставни и вообичаени механизми и брановидни шеми на виткање. Буката и габерот имаат брановидни листови чиишто агли на жилите се движат од 30 - $50^{\circ}$ од врвот до стеблото на листот. Лисјата со големи агли на жилите $\left(75-85^{\circ}\right)$ може да се превиткаат покомпактно отколку оние со мали агли $\left(30-45^{\circ}\right)$. Лисјата со мали агли на жилите пак уште во раните фази на размотување може да достигнат релативно голема површина. Потребната кинетичката енергија за целосно размотување се зголемува со аголот на жилите.

Листовите на австралиската палма Licuala ramsayi (Слика 6.10) обезбедуваат голема површина за апсорбирање на соларната енергија. Карактеристично за нив е тоа што тие се исечени на сегементи кои имаат улога на повеќе функции, меѓу кои е и можноста за реорганизација во аеродинамична форма при силен ветар и потоа нивно враќање неоштетени. 


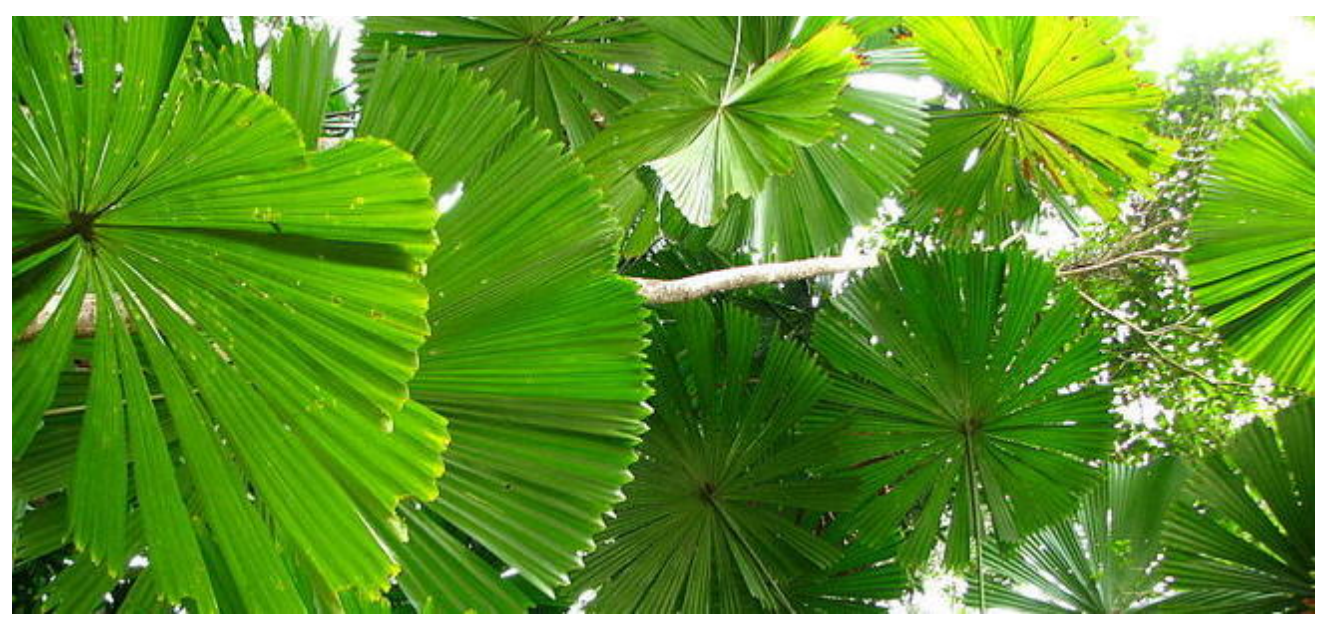

Слика 6.10 Австралиската палма Licuala ramsayi, има листови исечени на сегменти со голема површина за апсорбирање на соларната енергија

Многу цветови имаат ливчиња кои се отворени преку ден, но се затвораат ноќе. Овие цвеќиња реагираат на промени на интензитетот на светлина или промени на температурата. Топлината придонесува за растот на внатрешните sидови на цветните ливчиња. Па така, кога температурата опаѓа, надворешните sидови растат побрзо отколку од внатрешните зидови, и тоа е причината поради која цветот се затвора. Кај некои видови отворањето и затворањето се регулира со промени во интензитетот на светлина, а кај некои ноќни видови и со зголемување на релативната влажност на воздухот.

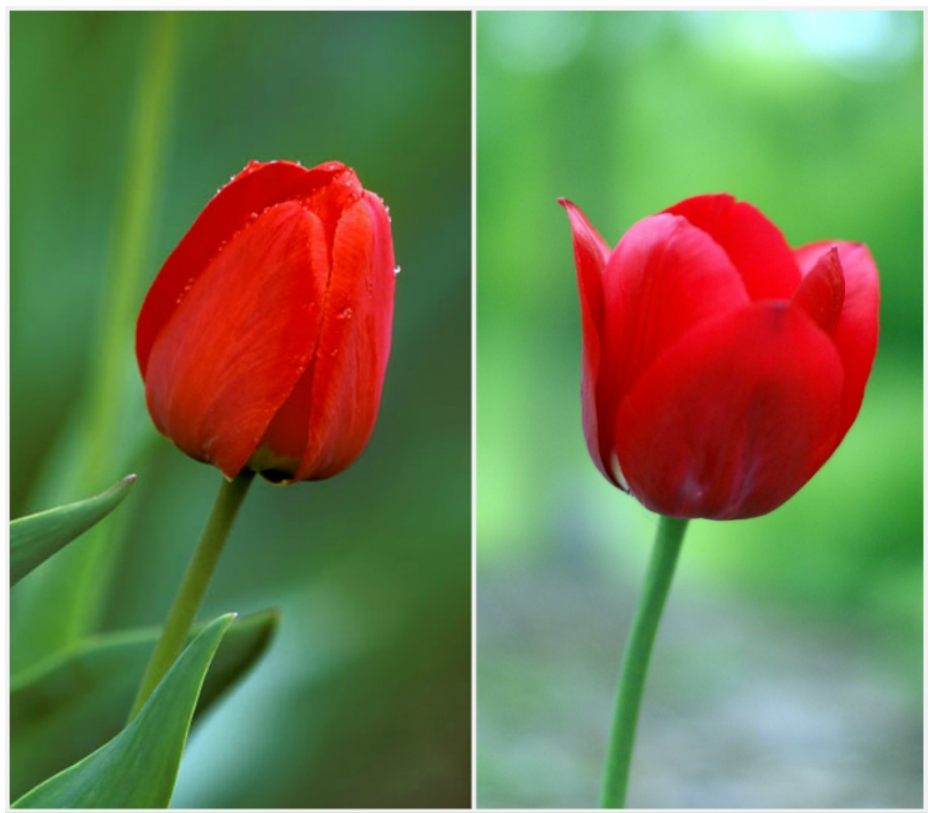

Слика 6.11 Цветните ливчиња кај лалињата се отвораат и затвораат како одговор на топлина и светлина 


\subsection{5 Економичност на простор и површина}

Преку набљудување на различни примери од природата ќе согледаме голем број на решенија и методи кои може да ни послужат како извор на инспирација за ефикасно искористување на просторот и површината.

Доколку го анализраме грашокот, распоредот на неговите зрна во мешунката е одличен пример за максимално и ефикасно искористување на малиот простор. Густо збиени и подредени, групирани еден до друг во целост ја исполнуваат внатрешноста. Мешунката пак како надворешна обвивка е флексибилна и водоотпорна и обезбедува сигурна заштита и средина за растење и созревање на семето. Видливите линии на спој кај мешунката кои се структурлано слаби овозможуваатт лесно отварање по созревањето. Вакви примери може да се видат и кај други мешункасти култури.

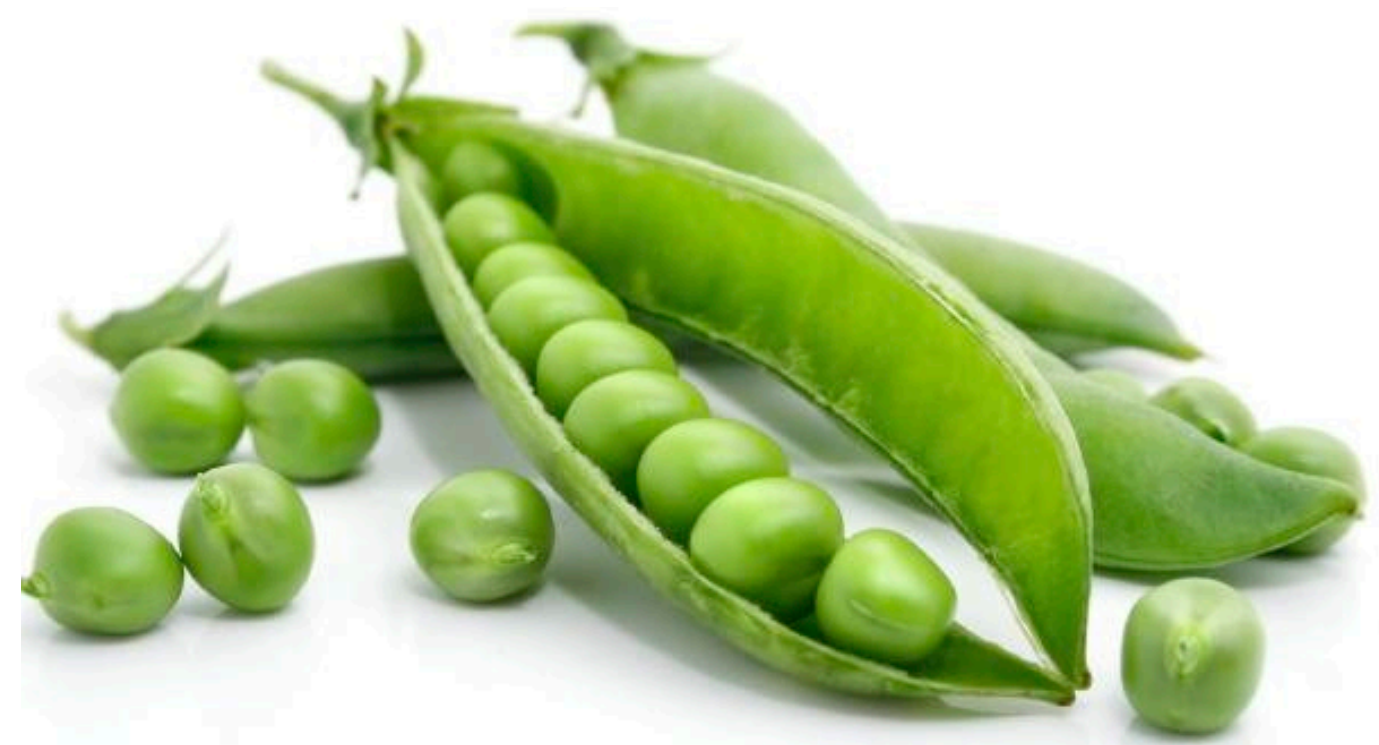

Слика 6.12 Максимално и економично искористување на простор кај мешунка грашок

Преку претходниот пример веќе согледавме дека организирањето во природата е секогаш економично, но и со трошење на најмал износ на енергија и користење на најмалку материјал потребен за извршување на задачите. Аголот од $120^{\circ}$ за спој на тромеѓе е најекономичен агол, кој во природата се сретнува доста често. Токму затоа и пчелите и осите градат хексагонални структури, кои истовремено се извондредно силни и лесни. 


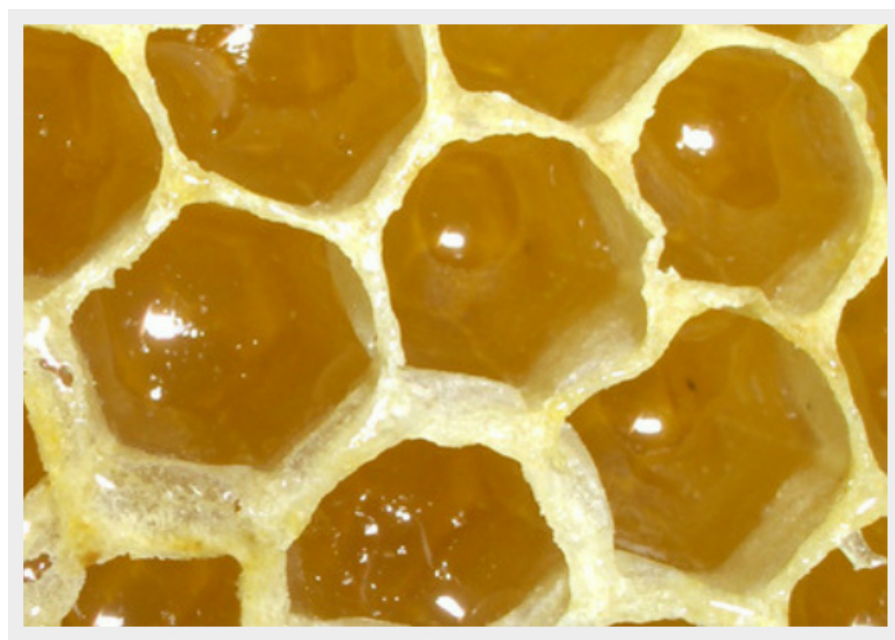

Слика 6.13 Хексагонална структура кај пчелите. Најефикасен начин за поделба на рамна површина кој исто така обезбедува максимална цврстина

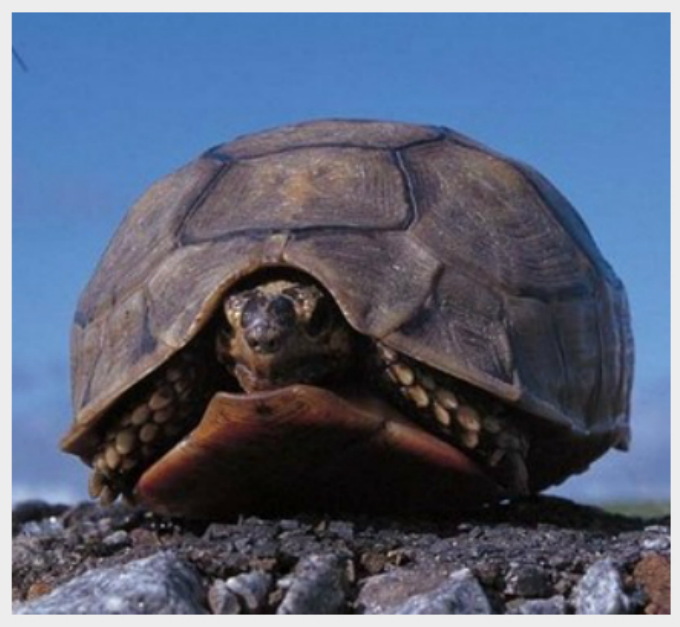

Слика 6.14 Хексагонална површина на закривена форма

Но, кога на закривени форми се јавуваат хексагонални површини и агол од $120^{\circ}$, секогаш постојат некои други облици и агли вметнати за да се компензира искривувањето. Таков е примерот со оклопот на желката (Слика 6.14), каде шестоаголниците во центарот се граничат со петоаголници (пет еднострани форми) кои ги соединуваат за да се даде прав раб на оклопот.

Истото се случува и со крилјата на инскетите. Тројното спојување се појавува кога делчиња со слична големина и форма треба да се преклопат за да покријат одредена површина (пр. пердувите на птиците, крлушките кај рибите, крлушките кај панголинот).
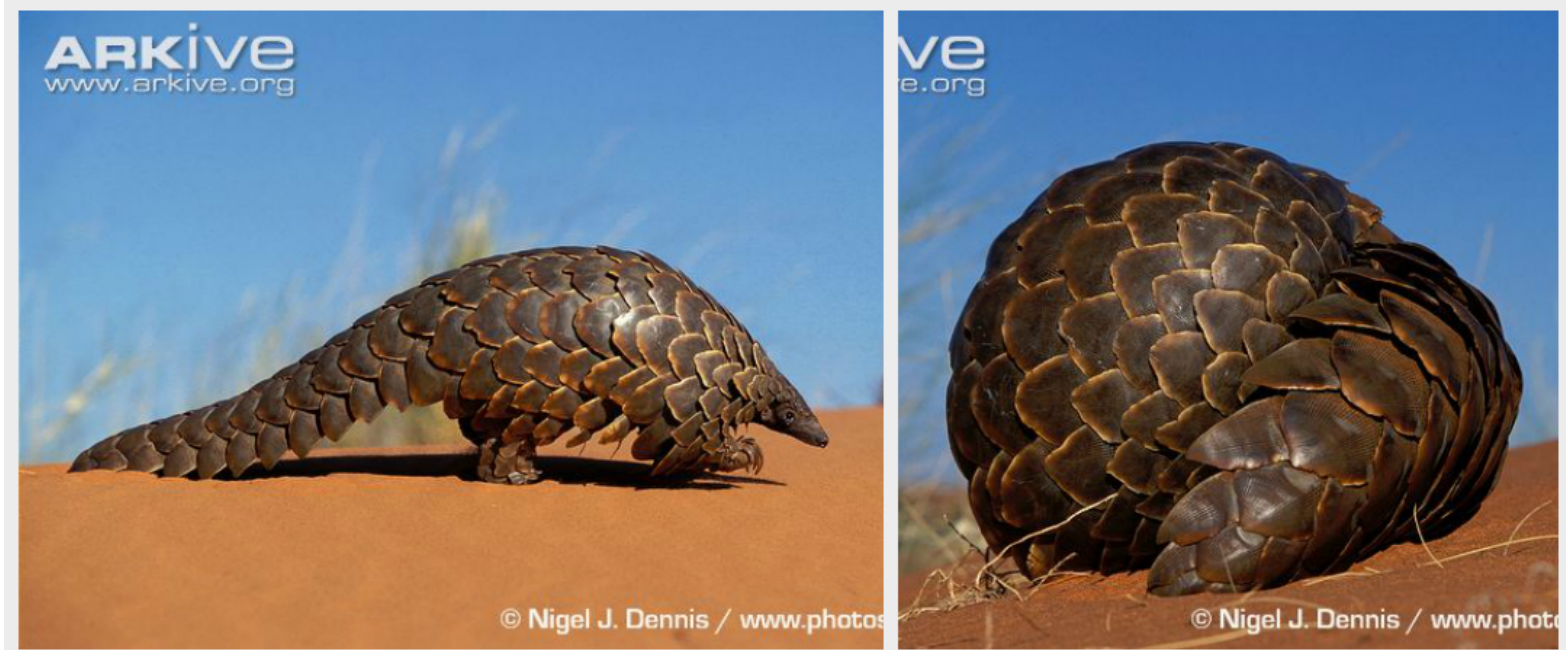

Слика 6.15 Панголин. Тројно спојување на делчиња со слична површина и форма 


\subsection{6 Хелиотропизам}

Многу растенија се познати по нивната способност да го следат движењето на Сонцето по хоризонтот. Овој процес се нарекува хелиотропизам. Одредени растителни видови ги ориентираат своите лисја или цветови под агол нормален на сончевите зраци за да обезбедат максимална светлина потребна за процесот на фотосинтеза. На пладне пак, за да избегнат прегревање тие може да ја сменат својата ориентираност и да се позиционираат паралелно на сончевите зраци. Затоплувањето од сонцето за растенијата е особено важно во студените предели како што е регионот на алпите или арктикот. Тука вирее познатото снежно лутиче (snowbuttercup), додека во нашите краишта најпознат е сончогледот.

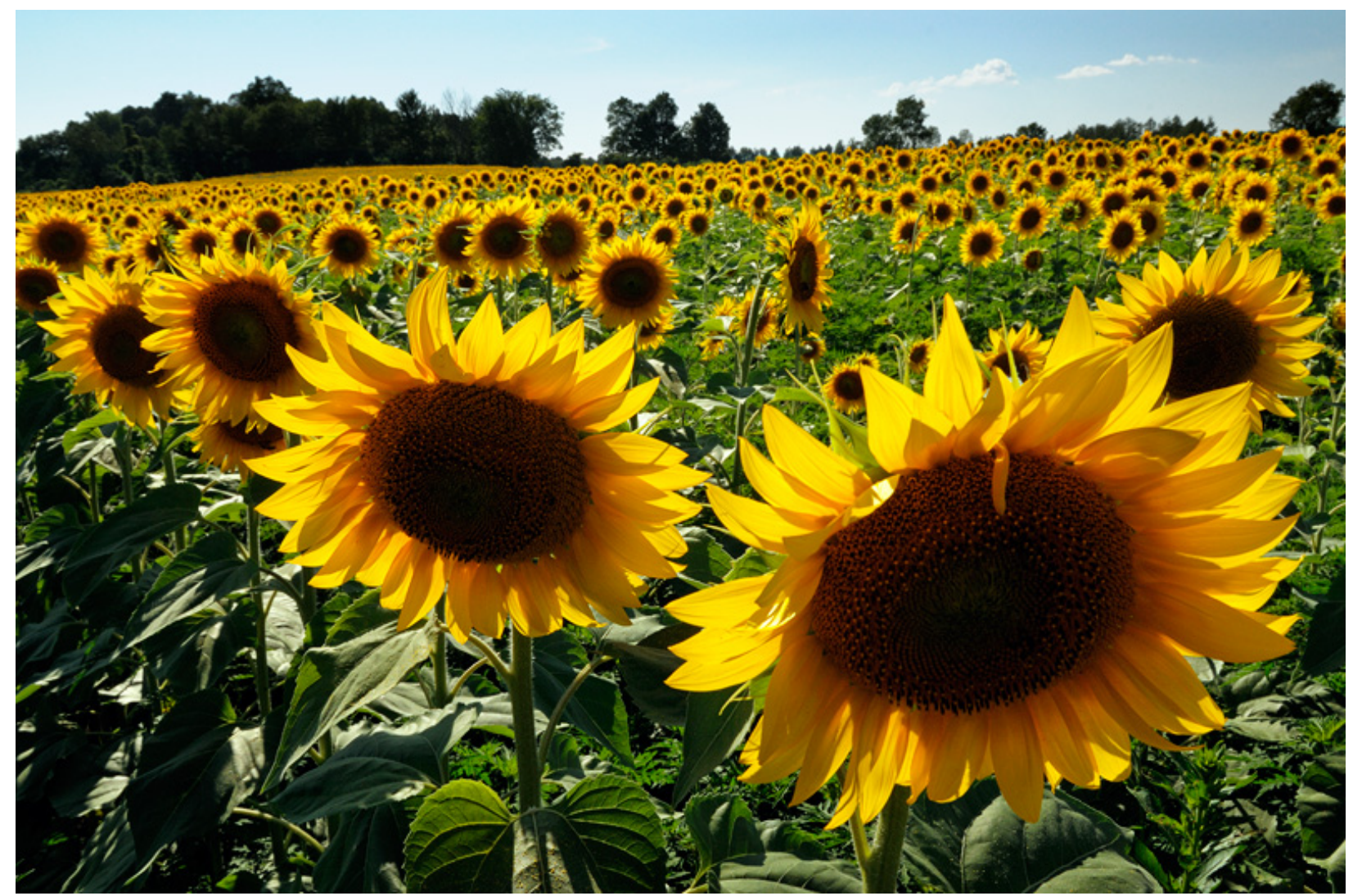

Слика 6.16 Способноста на сончогледот секогаш да се врти кон Сонцето е позната како хелиотропизам 


\section{5 Генерирање на концепти}

Ова е фаза на создавање на идеи и концепти според претходно утврдените начела и бионички модели. Врз основа на тоа развиени се следните концепти:

\section{Концепт 1-а}
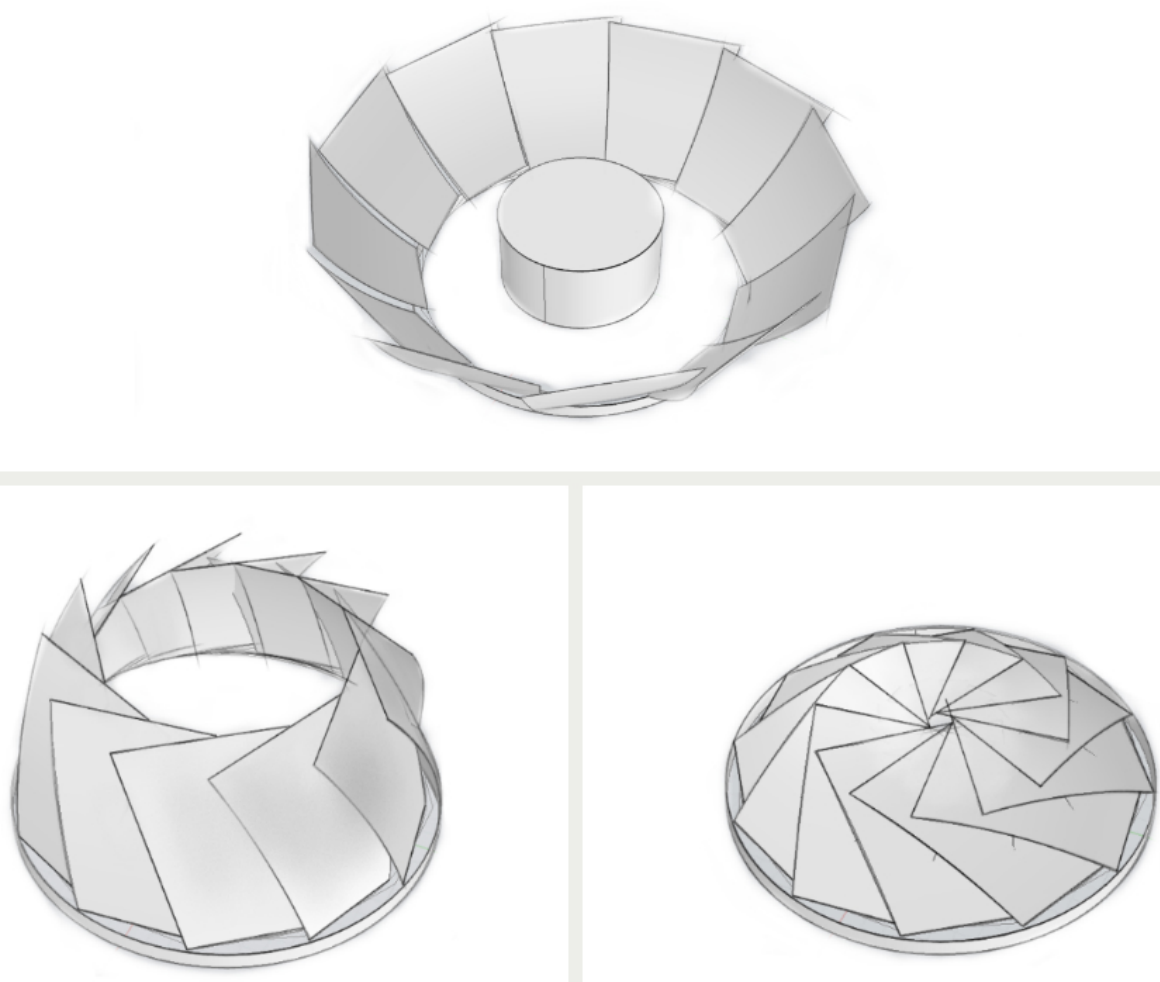

Цртеж 6.1

Бионички модел: отворање и затворање на ливчињата кај цветовите

Концептите прикажани на Цртеж 6.1 и Цртеж 6.2 претставуваат решение на рефлектирачката површина, инспирирани од флексибилноста на некои листови на цветови да се отвораат и затвораат при надворешни промени. Токму оваа функцијата е пренесена врз дизајнот, односно формата на рефлектирачките панели. Расклопувањето и склопувањето е лесно и интуитивно, а барањето за компактност е задоволено. Во средината треба да се најдат садовите за готвење. 


\section{Концепт 1-б}

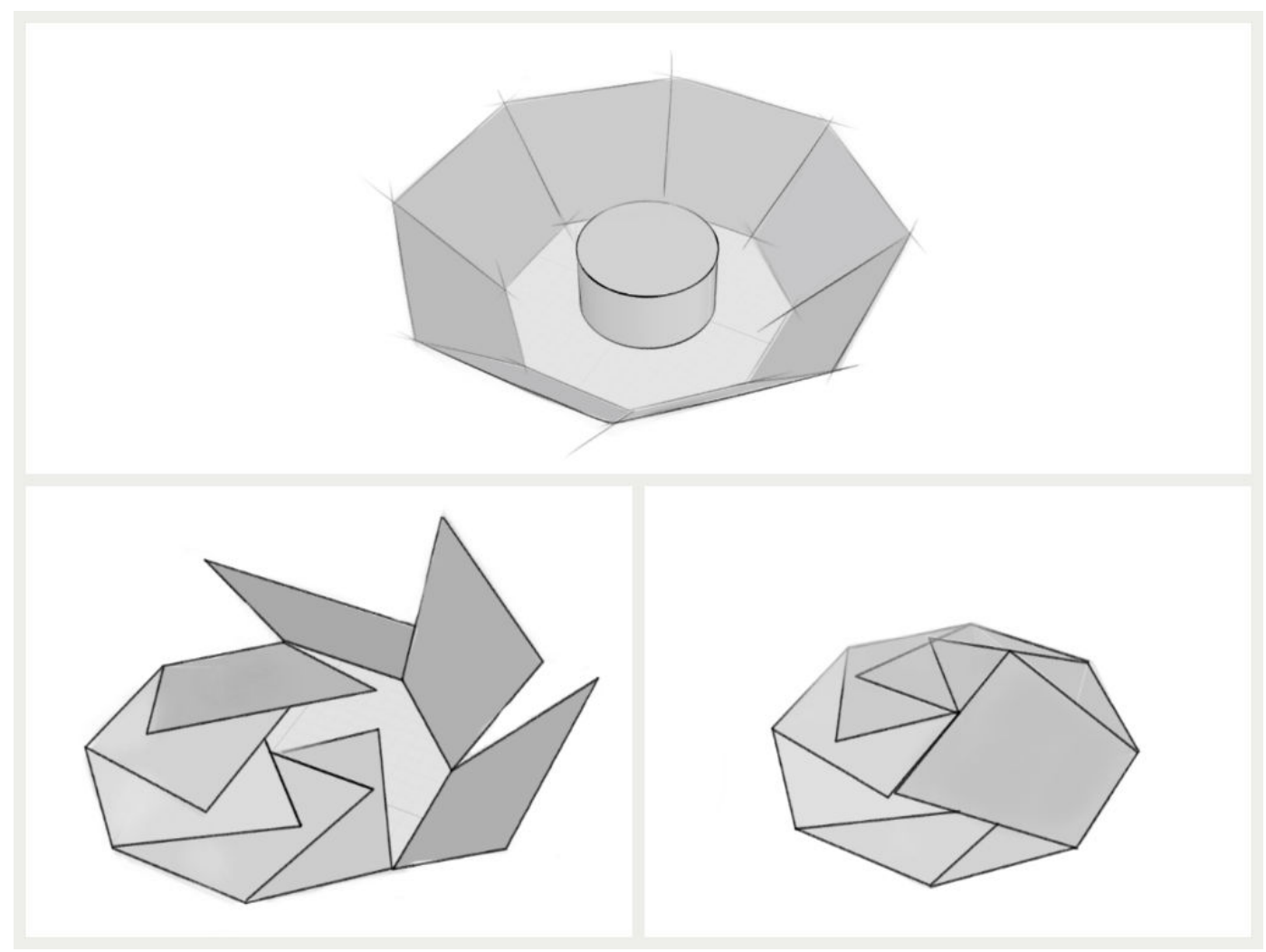

Цртеж 6.2

\section{Концепт 2}

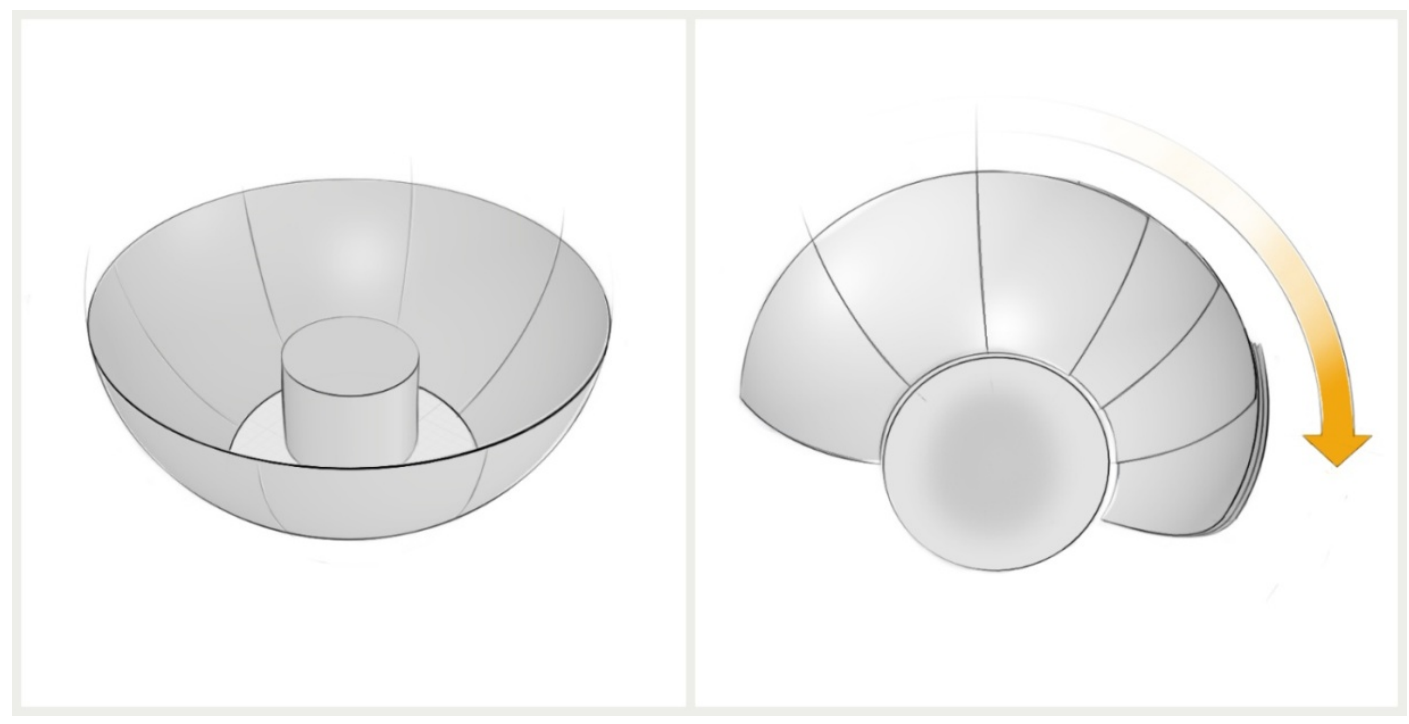

Цртеж 6.3

Бионички модел: сегментиран скелет кај членконогите и листовите на австралиската палма 
Уште еден пример прикажан на Цртеж 6.3, кој по својата форма можеме да кажеме дека прилично потстетува на претходно изнесените. Но за разлика од нив, начинот на собирање на рефлектирачките панели е различен. Тие се јасно сегемнтирани како скелетот кај членконогите или пак сегментираните листови на австралиската палма. При собирање секој сегмент навлегува под претходниот, со што доаѓа до намалување на површината.

\section{Концепт 3}

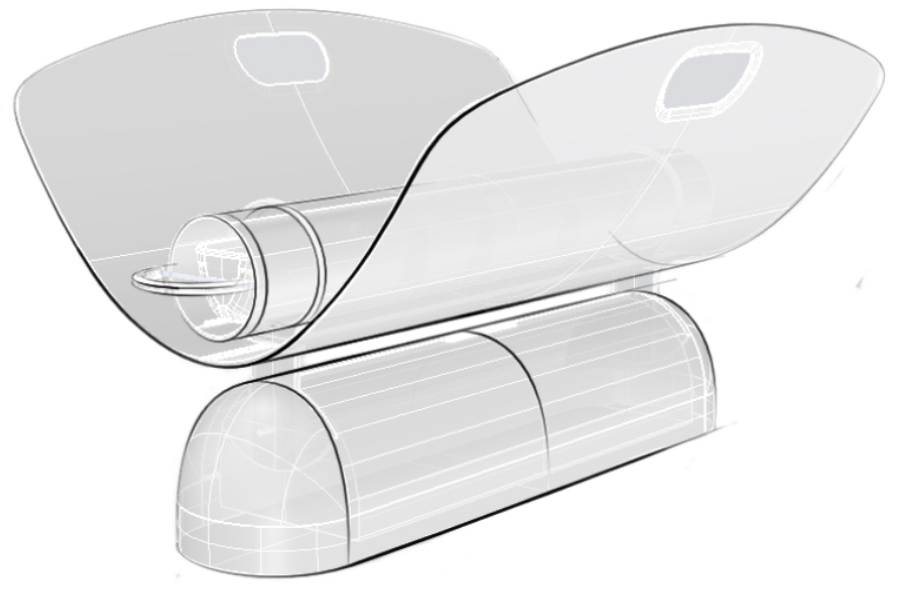

Цртеж 6.4

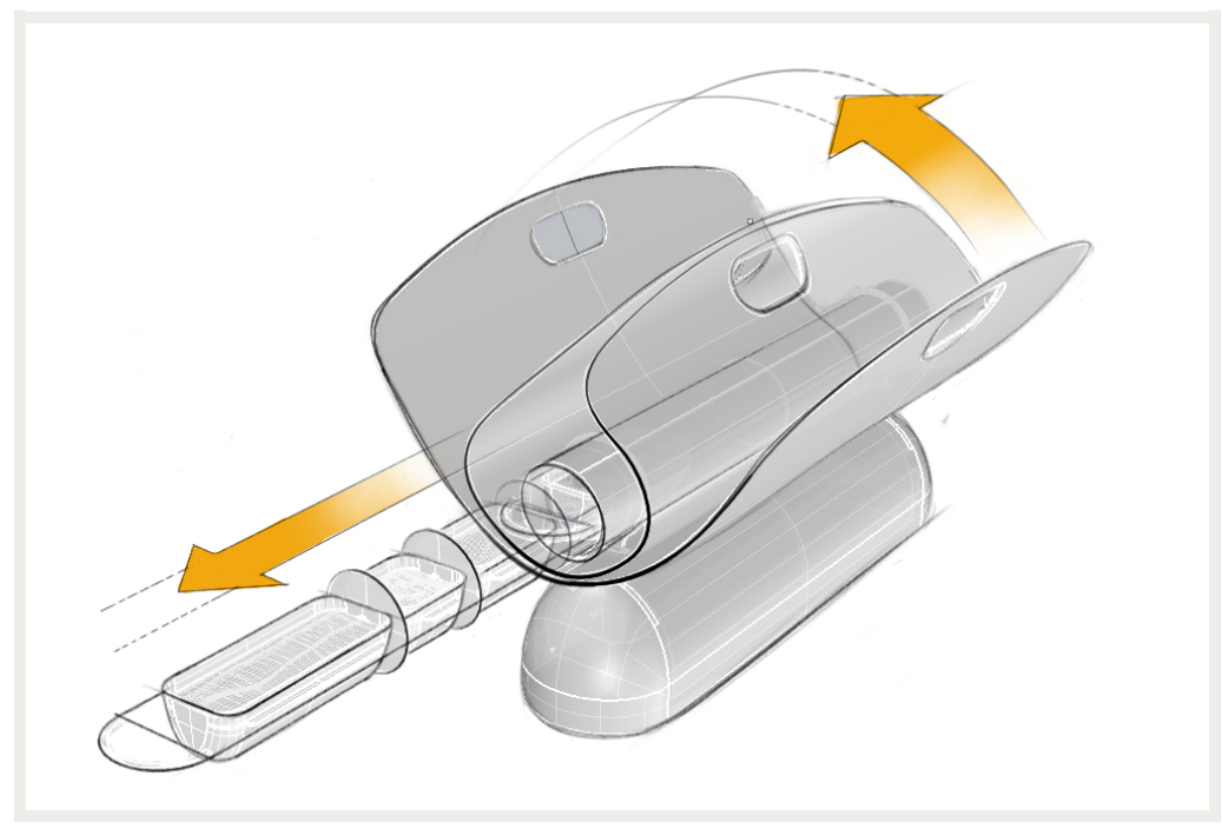

Цртеж 6.5 
Бионички модел: форма и функција на пеперутка, економичност на мешунка грашок

Формата на овој концепт е иснпирирана од крилјата на инсектите, односно самиот изгледа на пеперутката. Просторот во внатрешноста на зоната за готвење е подреден и максимално искористен исто како и кај зрната во мешунката на грашок. Рефлектирачките параболи при пренос еластично се виткаат една кон друга со што се задржува комапктноста на формата.

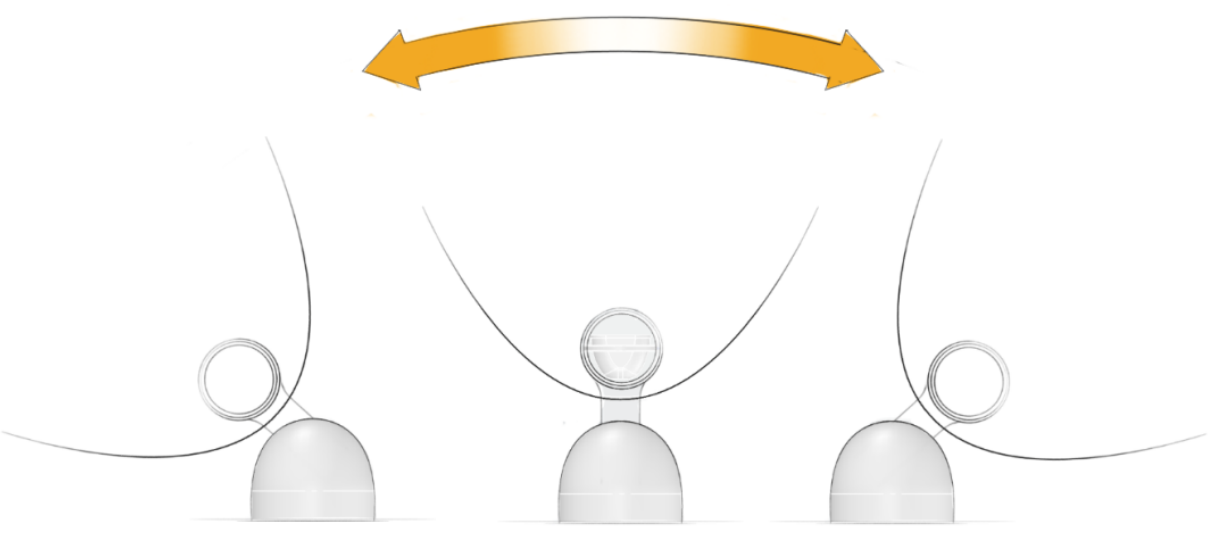

Цртеж 6.6

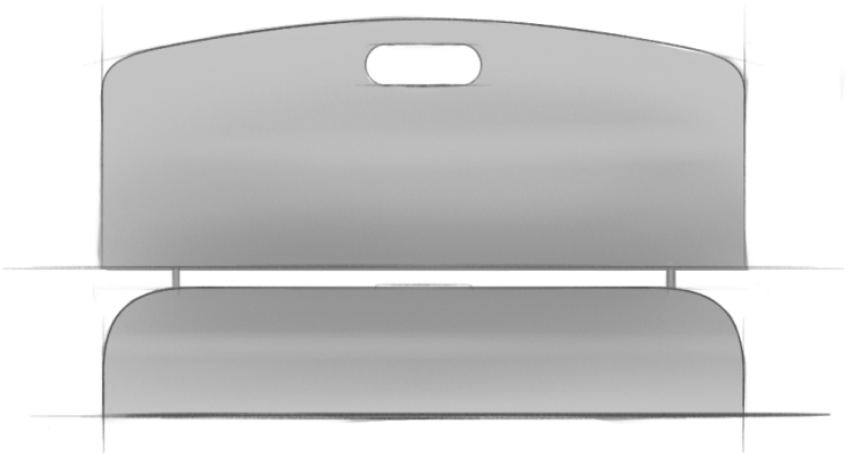

Цртеж 6.7 


\section{6 Избор на најсоодветен концепт}

Направена е анализа за оценување со која се дефинира кој од концептите е подобар, односно задоволува повеќе од барањата. Анализата на оценување е направена со графикон во облик на пајакова мрежа каде барањата се оценуваат со оцени од 1 до 5 во зависност колку дадениот концепт го исполнува барањето. Оцените се претставени на оски кои почнуваат од иста точка.

Оценувањето на концептите е извршено со поставување на 10 барања, а резултатите се прикажани на Графикон 6.1 за концептот број 1, Графикон 6.2 за концептот број 2, Графикон 6.3 за концептот број 3.

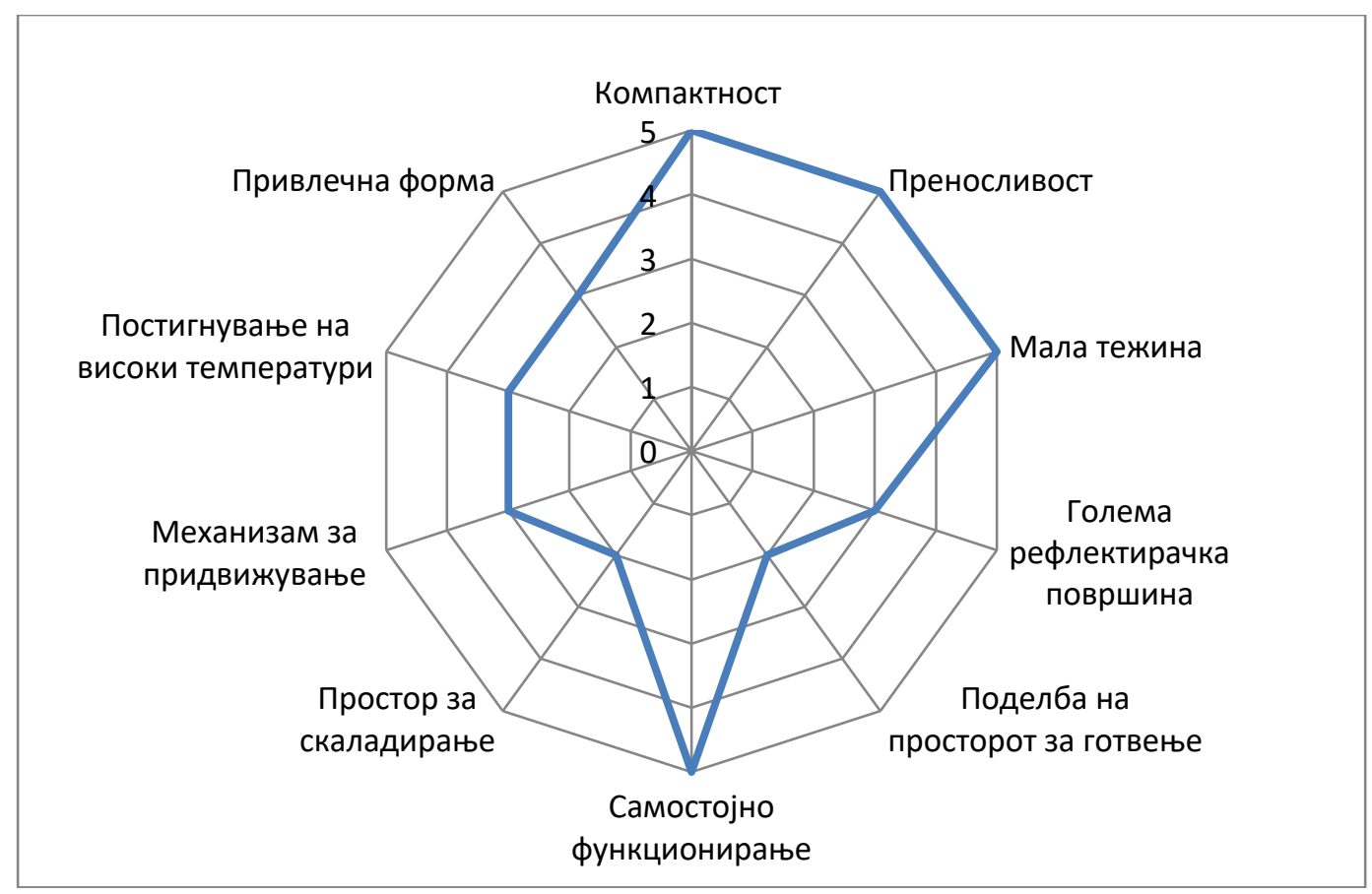

Графикон 6.1 Оценување на концепт бр. 1 


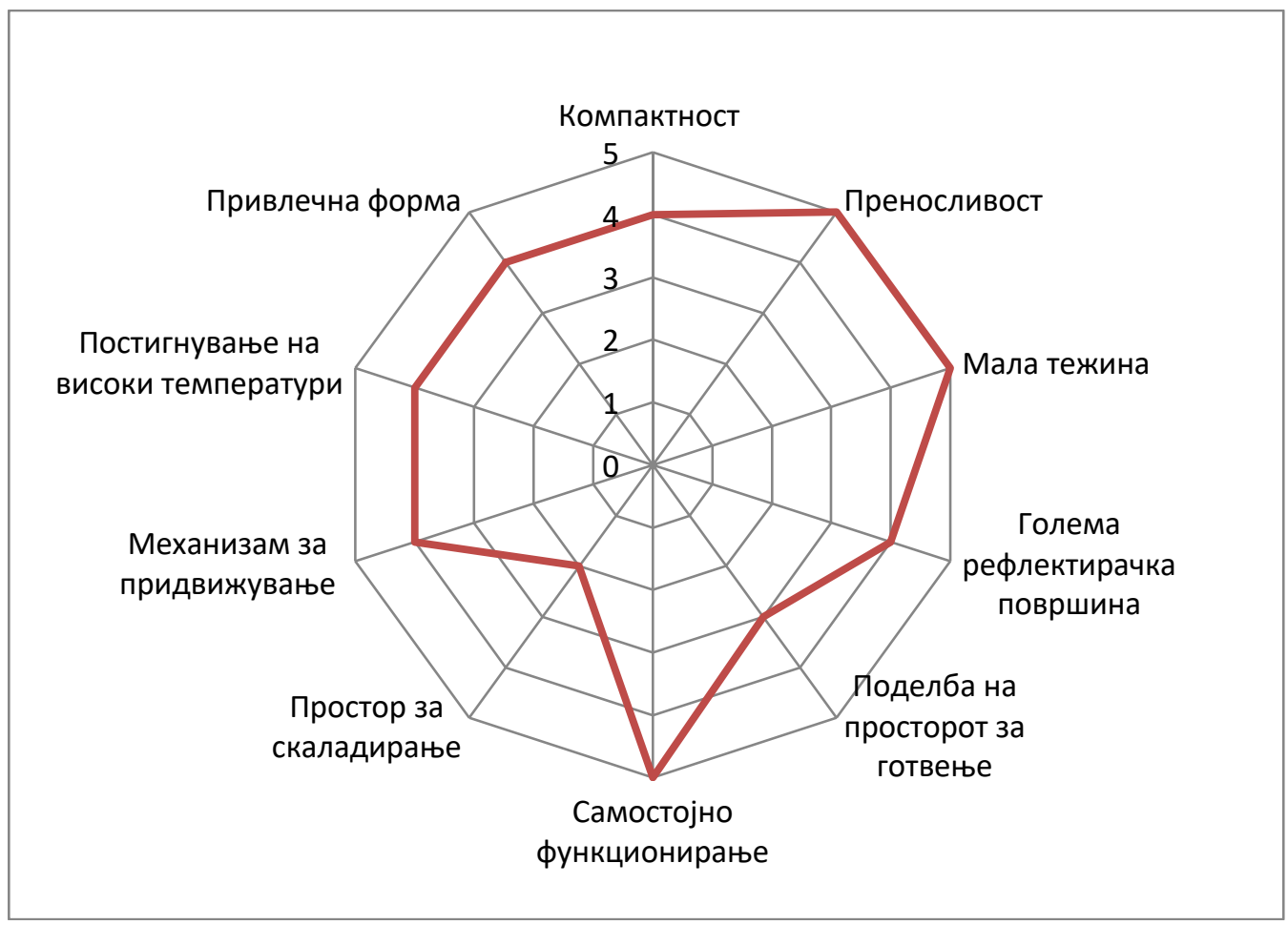

Графикон 6.2 Оценување на концепт бр.2

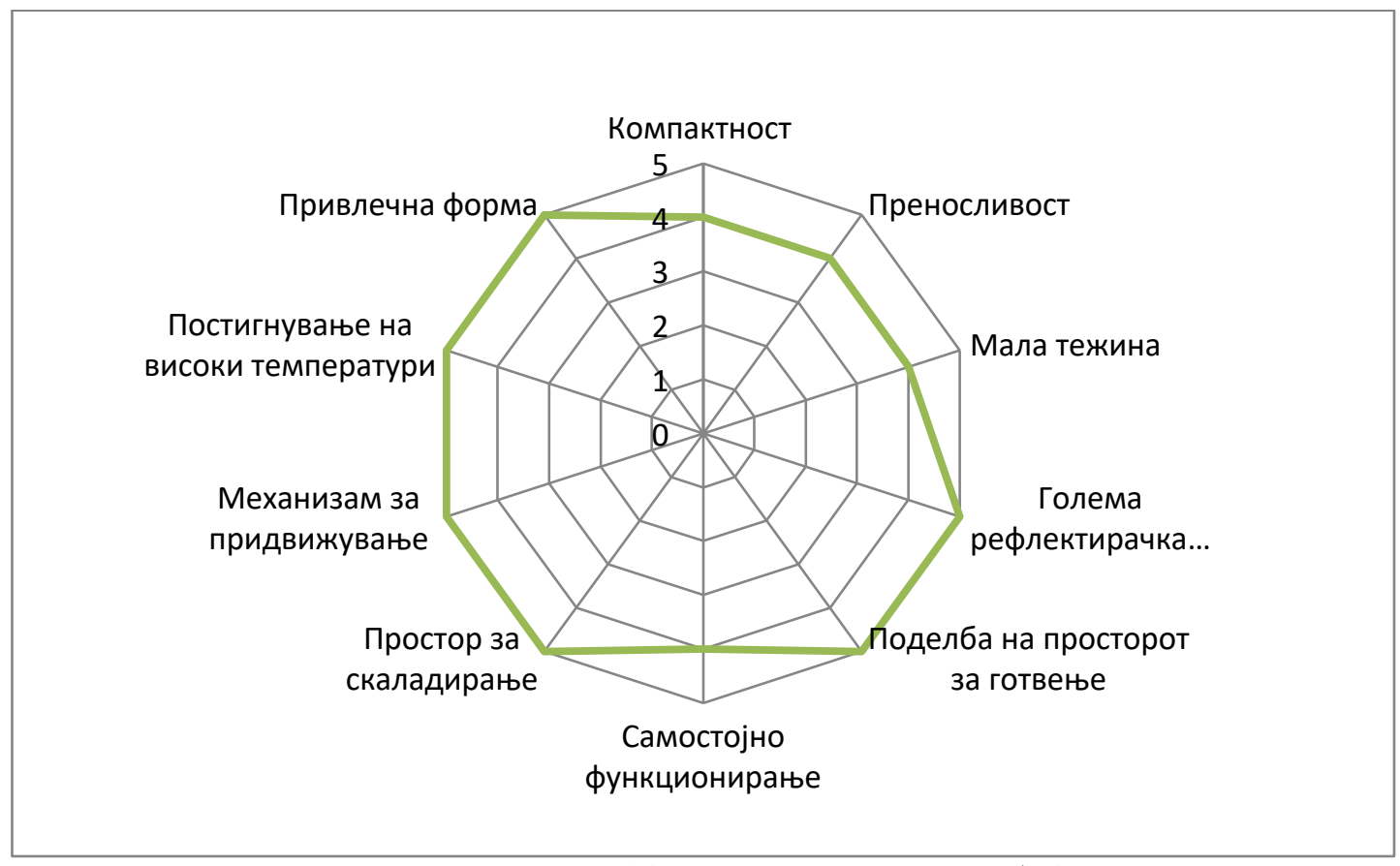

Графикон 6.3 Оценување на концепт бр.3 


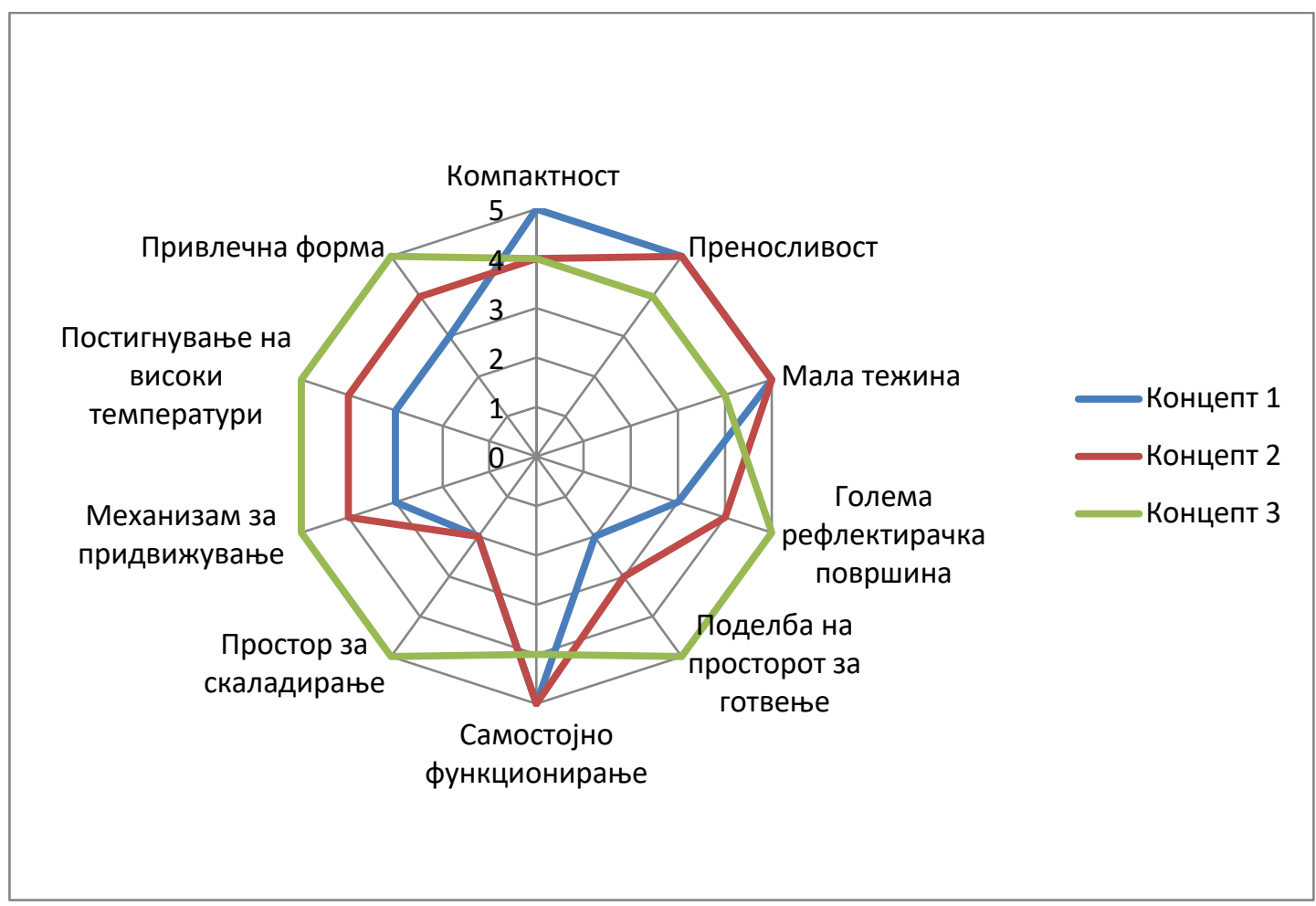

Графикон 6.4 Споредба на анализите за оценување на концептите

На Графикон 6.4 направена е споредба на трите анализи за оценување за да се одреди најдобриот концепт. Според извршената анализа највисоки оцени доби концептот број 3, со што овој концепт ќе подложи на понатамошна детална разработка прикажана во поглавието 7. 


\section{7. Детална разработка на конечниот концепт}

Оваа фаза го опфаќа деталниот опис на компоненти, нивниот начин на функционирање, изработка на технички цртежи и сите соодветни разгледувања потребни за разбирање на проектот.

\section{1 Одредување на фокус кај парабола и примена на nodamouume}

Пресметувањето на фокусот при дизајнирањето на параболичните соларни уреди е од суштинско значење. Тој ни ја покажува оптималната позиција на апсорберот во однос на параболата со цел постигнување на максимални резултати.

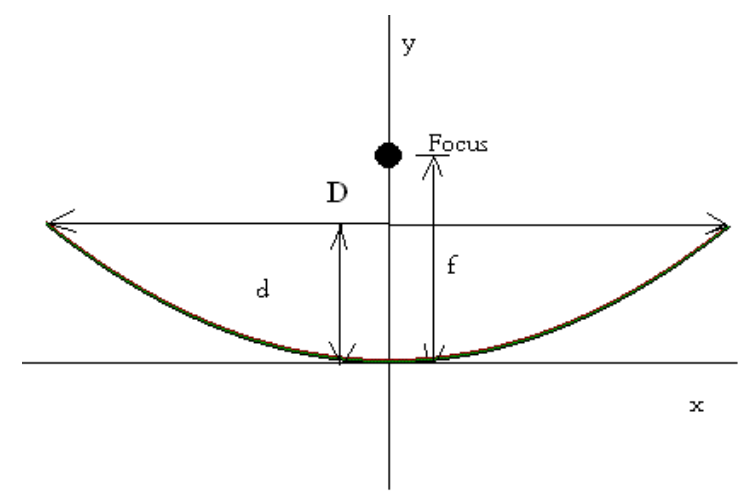

Слика 7.1 Елементи на парабола
Позицијата на фокусот на параболата може да се одреди според математичка формула. Таа е следна:

$$
f=D^{2} / 16 d
$$

каде D претставува дијаметар на параболата, d е длабочина (висина), f e фокус.

На располагање постојат и софтвери каде со внесување на потребните параметри се одредува параболата, се пресметува позицијата на нејзиниот фокус и истите графички се прикажуваат. Еден од нив е Parabola Calculator 2.044 (Слика 7.2)

\footnotetext{
${ }^{44} \mathrm{http}: / /$ mscir.tripod.com/parabola/ 


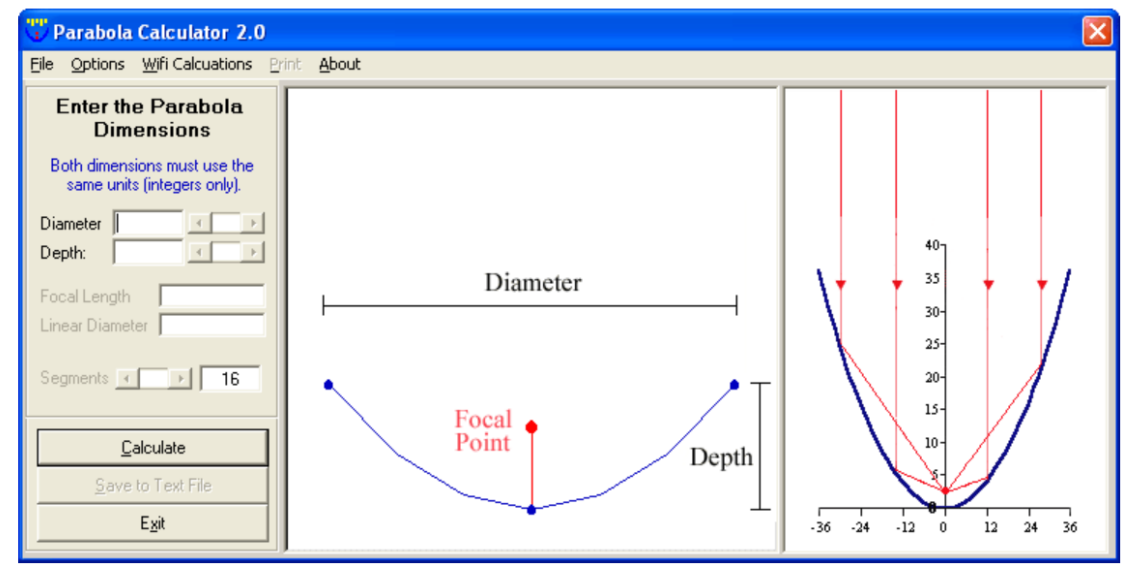

Слика 7.2 Софтвер за пресметување фокус на парабола

Во овој труд параболичниот рефлектор е со следните димензии: $\mathrm{D}=520 \mathrm{~mm}$; $\mathrm{d}=$ $260 \mathrm{~mm}$.

По внесувањето на овие параметри во бараните полиња калкулаторот визуелно ја прикажа параболата и го пресмета фокусот кој се наоѓa на растојание од 65mm од подножјето (Слика 7.3).

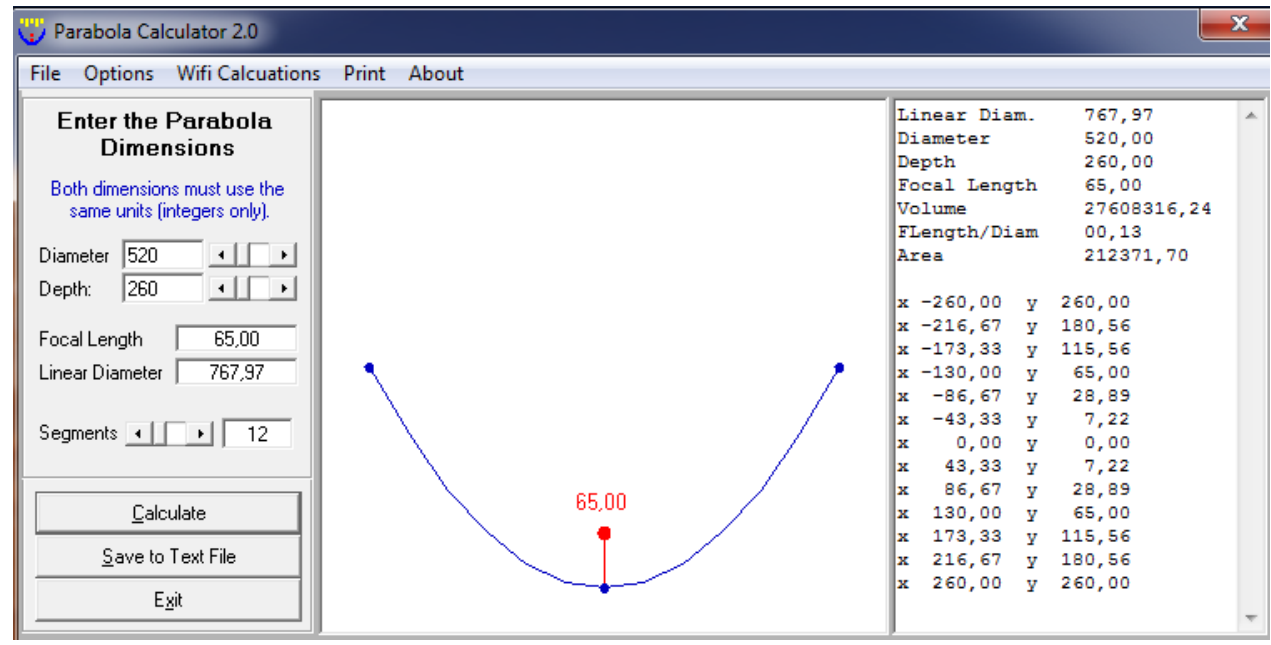

Слика 7.3 Пресметување на фокус на парабола според зададени димензии

Овие податоци понатаму се применуваат во процесот на дизајнирање и служат за одредување на позицијата на поставеност на зоната за готвење, односно стаклената цевка во однос на параболата. Од работилничкиот цртеж на Слика 7.5 јасно се гледа дека 
цевката е идеално поставена во фокусот. Направен е и дијаграм ${ }^{45}$ на рефлексија на светлинските зраци прикажан на Слика 7.4.

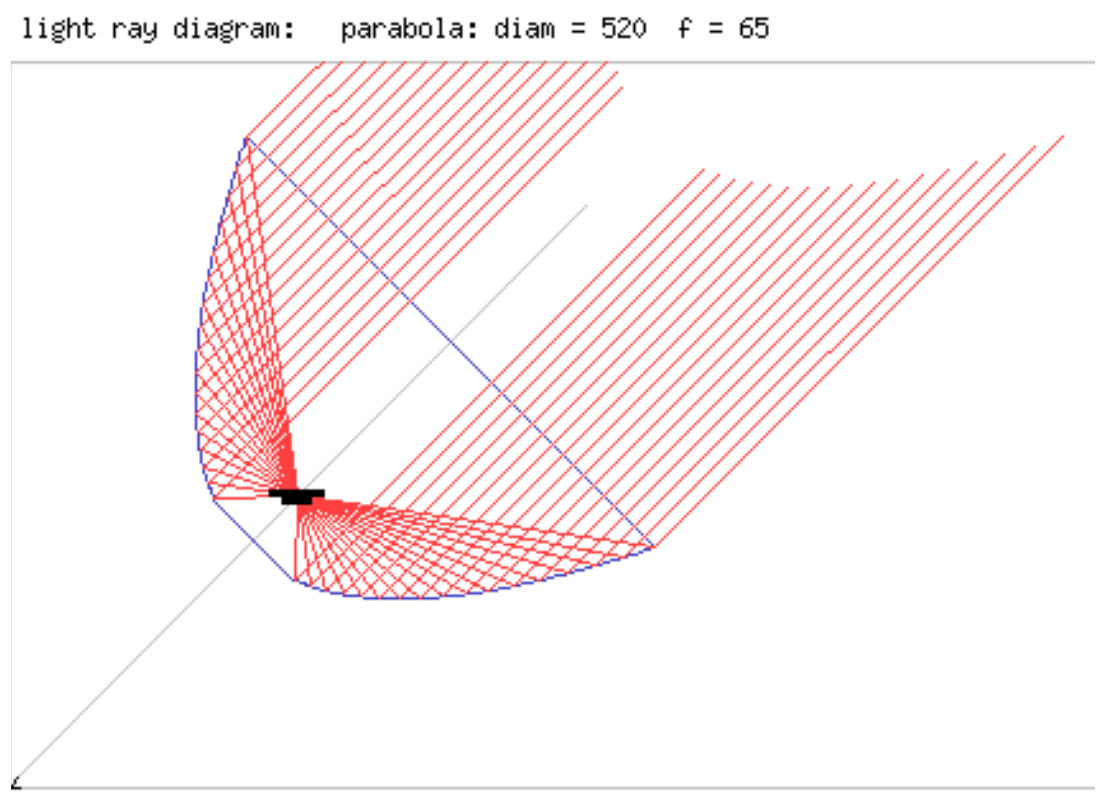

Слика 7.4 Дијаграм на рефлексијата на светлински зраци според зададени димензии. Дијаметар на парабола од $520 \mathrm{~mm}$ и фокус на $65 \mathrm{~mm}$

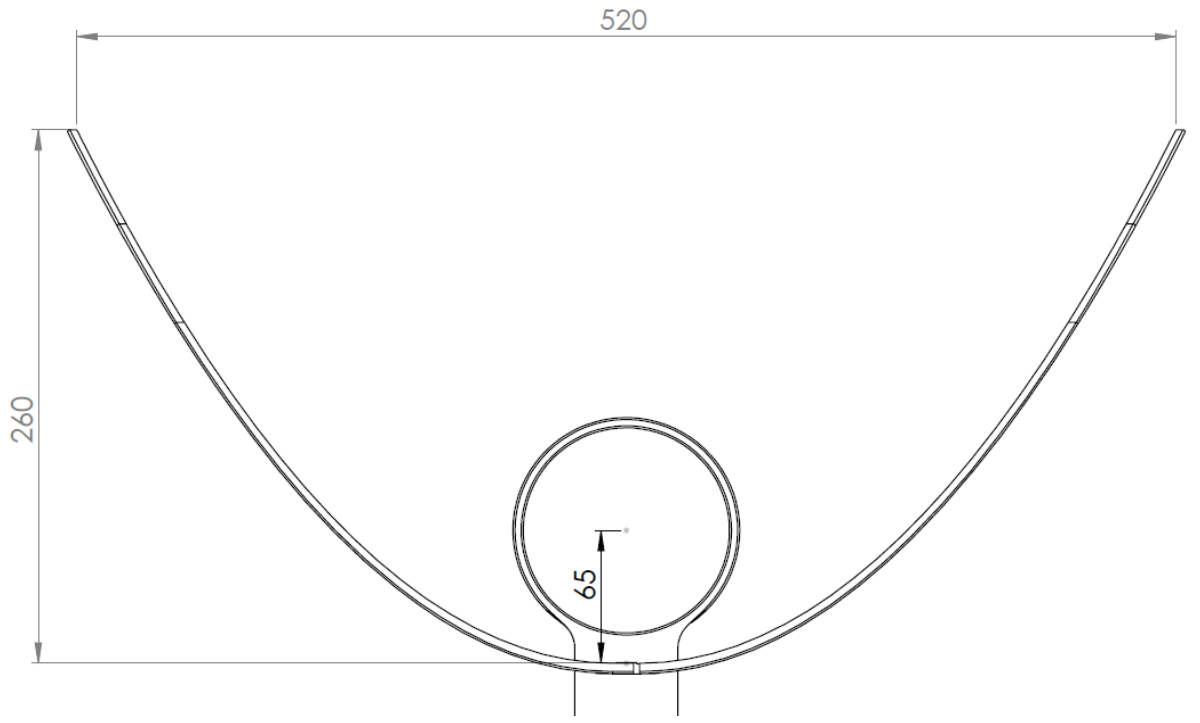

Слика 7.5 Работилнички цртеж на взаемната поставеност параболична површина - цевка

${ }^{45} \mathrm{http}: / /$ solaire-chauffe-eau.info/solar-parabola-construction.php 


\section{2 Основни составни елементи}

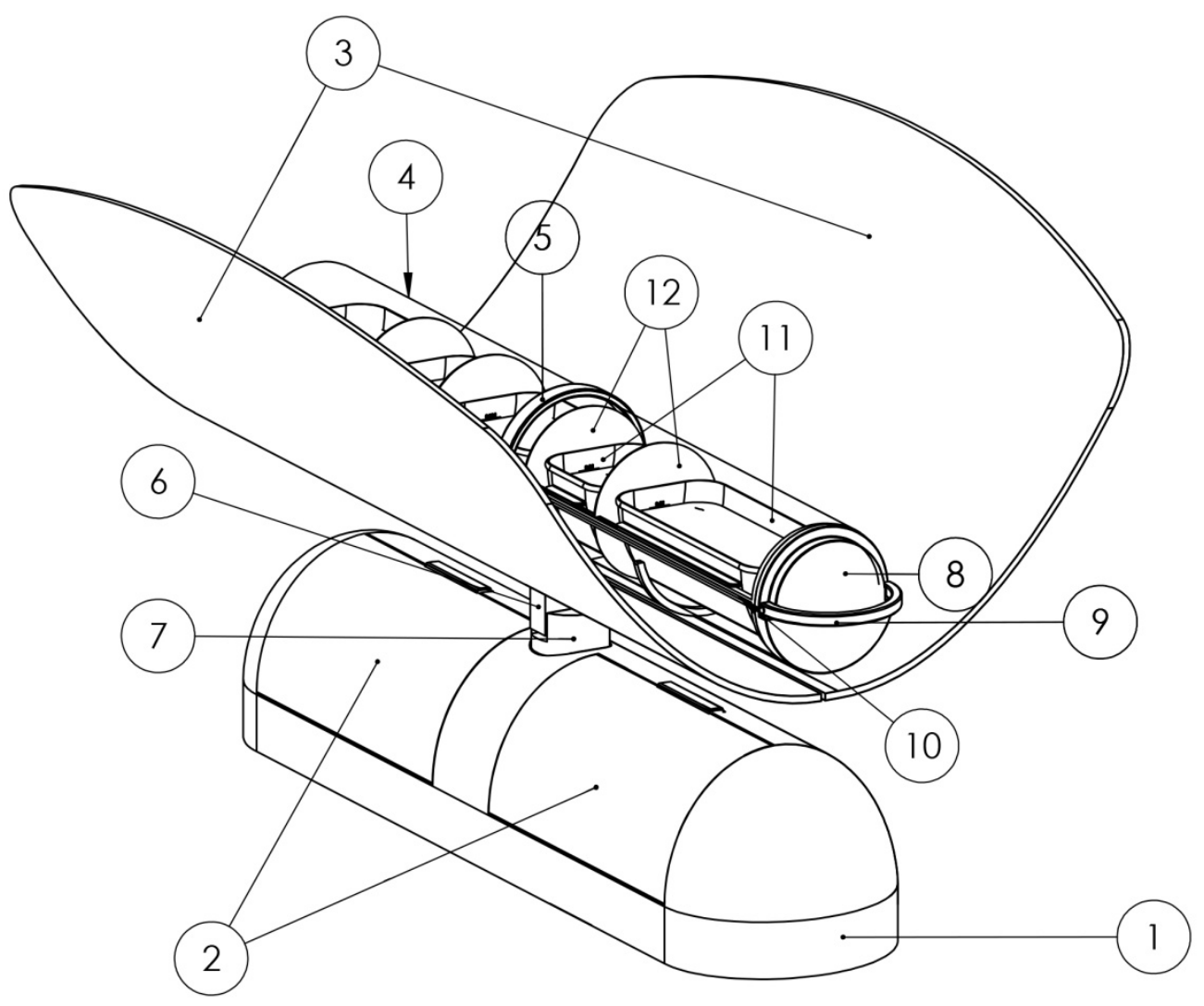

$\begin{array}{llll}1 & \text { Основа } & 7 & \text { Ротирачки држач } \\ 2 & \text { Простор за складирање } & 8 & \text { Страничен поклопец } \\ 3 & \text { Рефлектирачка параболична површина } & 9 & \text { Рачка за извлекување } \\ 4 & \text { Стаклена цевка } & 10 & \text { Рамка со лизгачи } \\ 5 & \text { Прстенест држач } & 11 & \text { Садови } \\ 6 & \text { Аголник } & 12 & \text { Прегради }\end{array}$

Слика 7.6 Составни елементи на соларниот готвач 


\section{3 Начин на функционирање}

Сончевите зраци кои паѓаат на параболичната површина (3) се рефлектираат од неа и се насочуваат кон стаклената цевка (4). Во нејзината внатрешност се сместени садовите (11) во кои се наоѓa храната како и преградите (12) меѓу секој од нив. Под дејство на топлината од Сонцето внатрешноста на цевката се загрева, топлината заробена во цевката почнува да циркулира во просторот околу садовите, температурата расте, храната почнува да се готви.

Кога храната е подготвена, со рачката (9) садовите од внатрешноста на цевката се извлекуваат надвор, а со помош на рачка за подигнување се вадат од рамката со лизгачи (10) каде се прицврстени.

\section{4 Придвижување и регулирање на аголот на рефлектирачката парабола}

Регулирањето на позицијата на параболичната површина, односно аголот на нејзинот наклон е решен со придвижување на аголникот. Изборот на аголот на наклон зависи од повеќе фактори. Начинот на функционирање и придвижување на елементите е следен:

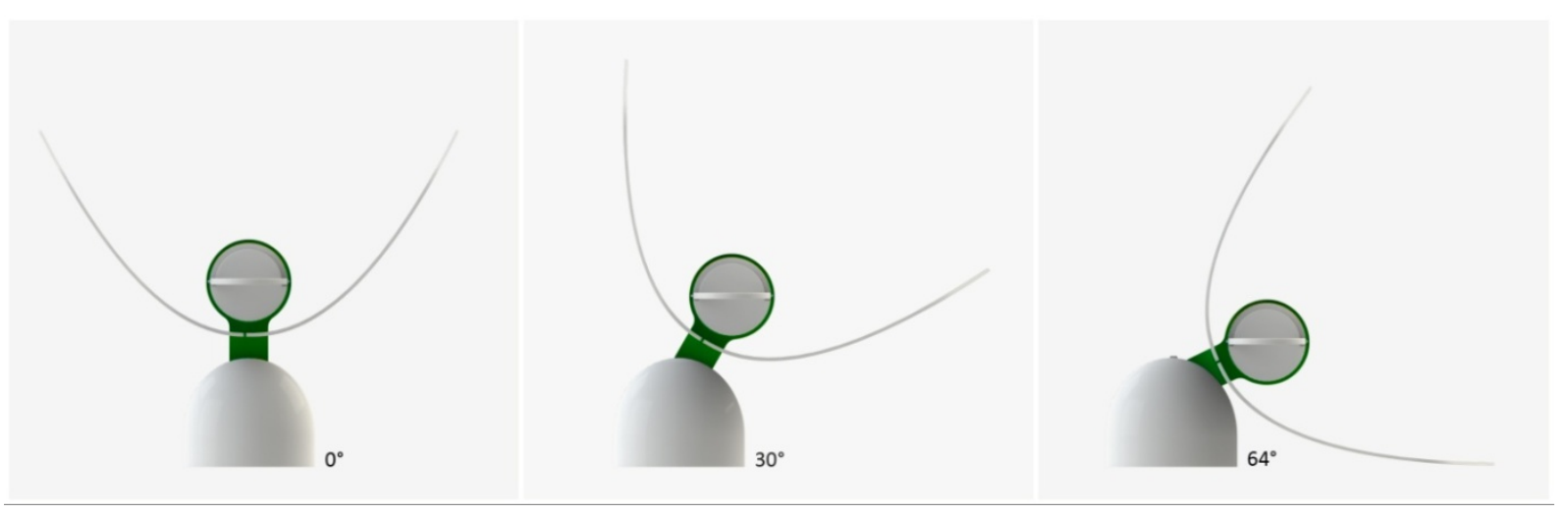

Слика 7.7 Позиции на параболата при промена на наклонот

Аголникот со интегрираниот прстенест држач е фиксно поврзан со рефлектирачката параболична површина, додека во однос на основата е подвижен. Цевката со садови пак ја “носи“ прстенестиот држач заедно со неговата конструкција. Со 
придвижување на аголникот доаѓа до менување на наклонот на параболичната површина. Поради фиксното поврзување параболична површина - аголник, цевката секогаш, без разлика на позицијата на параболичната површина се наоѓa во нејзиниот фокус. Придвижување на цевката се случува во рамките на прстенестиот држач кога доаѓа до промена на наклонот, каде под дејство на тежината на садовите и земјината гравитација таа ротира. На овој начин садовите со храна секогаш завземаат хоризонтална позиција.

Рефлектирачката параболична површина се придвижува на уште еден начин, а тоа е преку ротација. Ова е овозможено преку ротирачкиот држач кој се наоѓa во просторот помеѓу основата и параболичната површина. На овој начин рефлектирачката површина ротира во однос на основата преку z-оската. Менувањето на наклонот и ротацијата на параболичната површина може да се одвиваат истовремено.

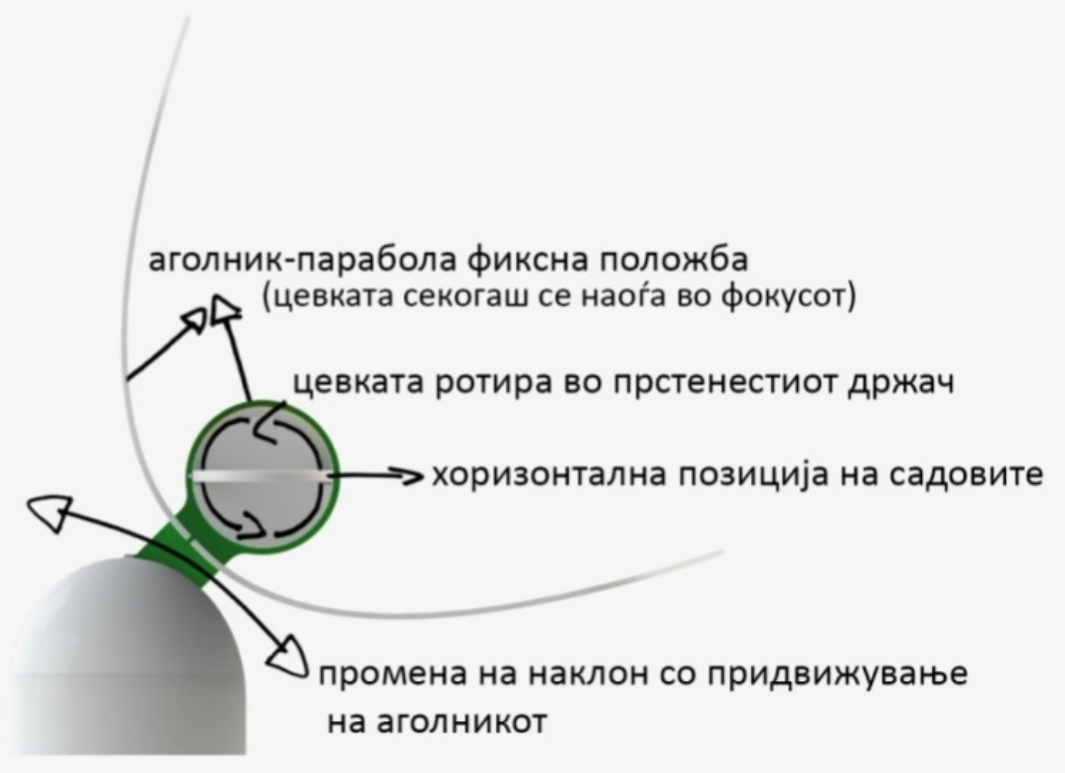

Слика 7.8 Начин на придвижување (функционирање) на елементите 


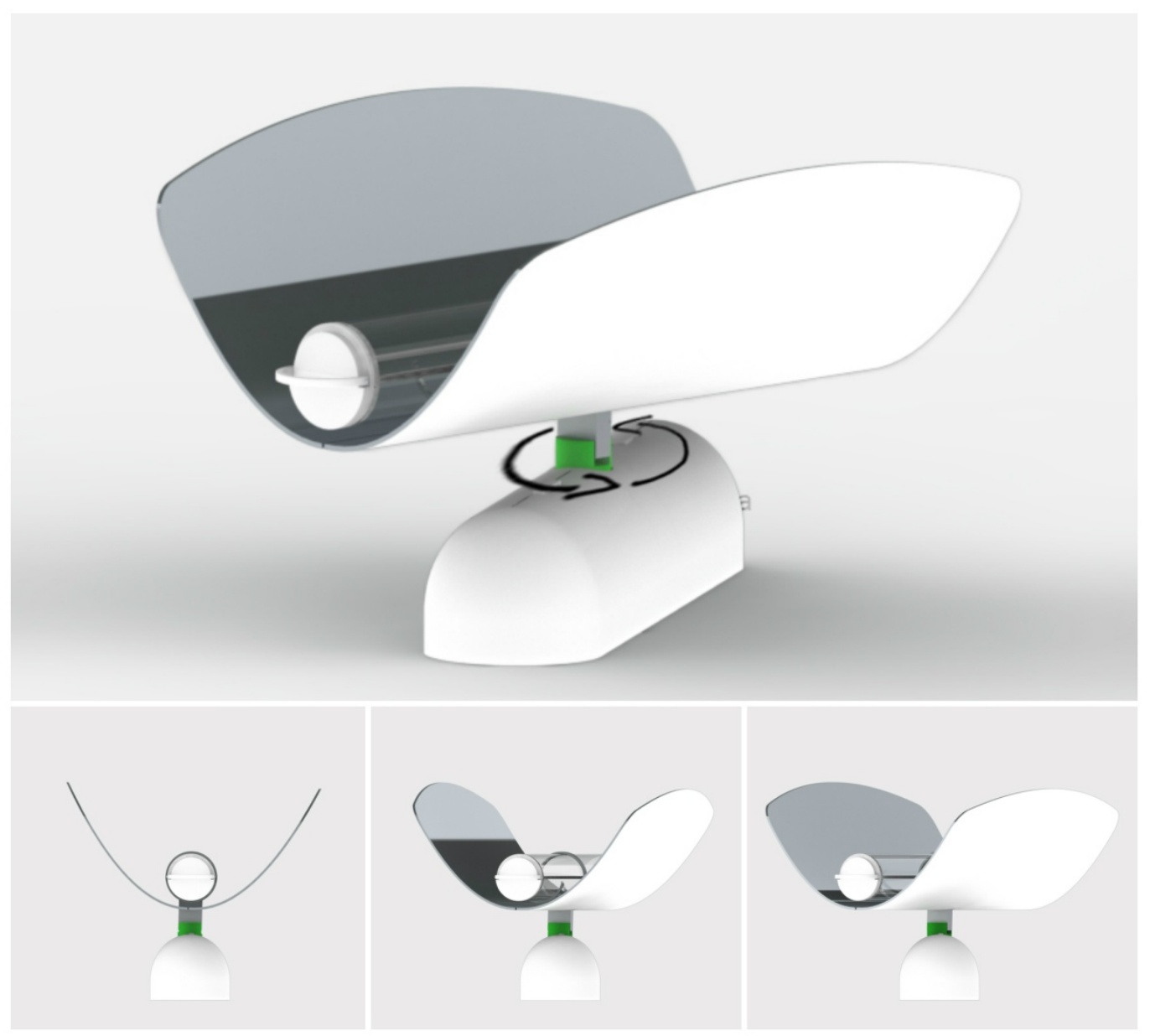

Слика 7.9 Придвижување на параболата со ротација 


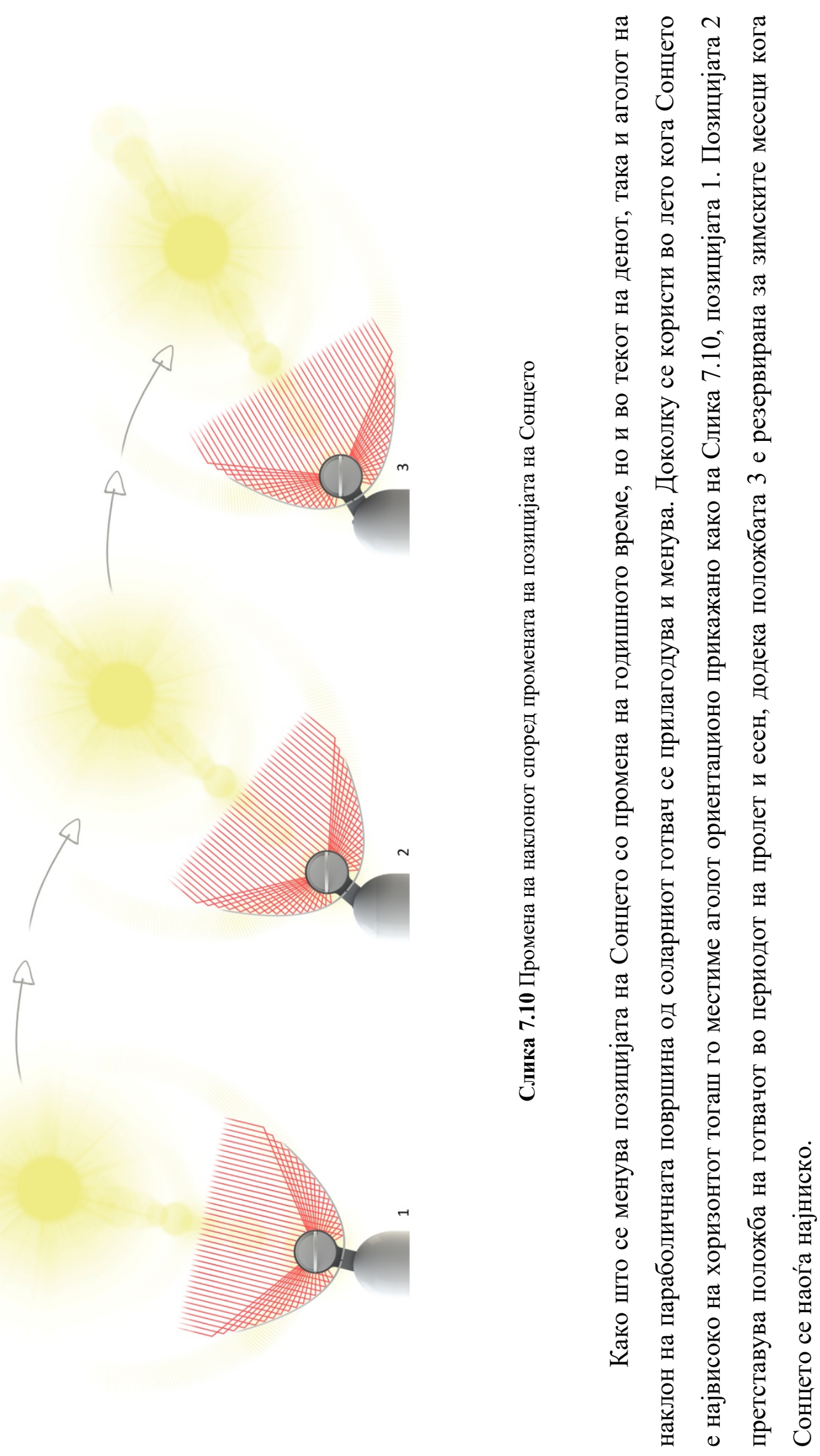




\section{5 Простор за складирање}

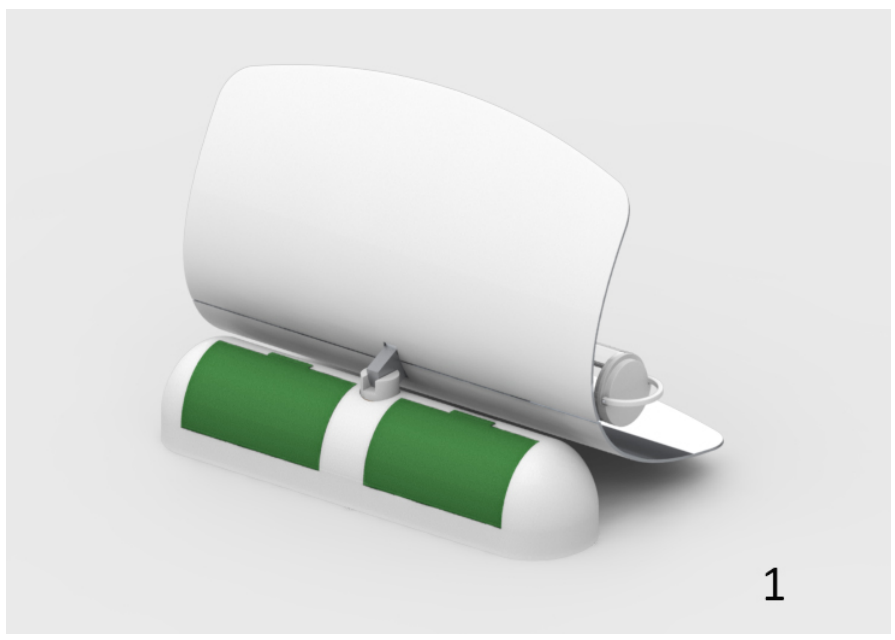

Просторот за складирање е сместен во самата основа. До него се пристапува преку задната страна на соларниот готвач. Тука се наоѓаат два отвори во вид на фиоки. Во просторот предвидено е да складираат садовите за готвење и тоа $3 \times 500 \mathrm{ml}, 3 \times 330 \mathrm{ml}$ и $4 \times 200 \mathrm{ml}$,

а останува и доволно место за сместување на дополнителни работи како прибор за јадење, некои зачини и сл. Начинот на функционирање е едноставен и прикажан на Слика 7.11. Фиоката во долниот дел е прицврстена со основата преку зглоб (шарка) со што е овозможена подвижност, додека горниот дел, односно системот на затворање и отворање е решен преку жлеб.

Како простор за складирање на садовите се користи и самата цевка.

Слика 7.11 Фиоки и простор за складирање 


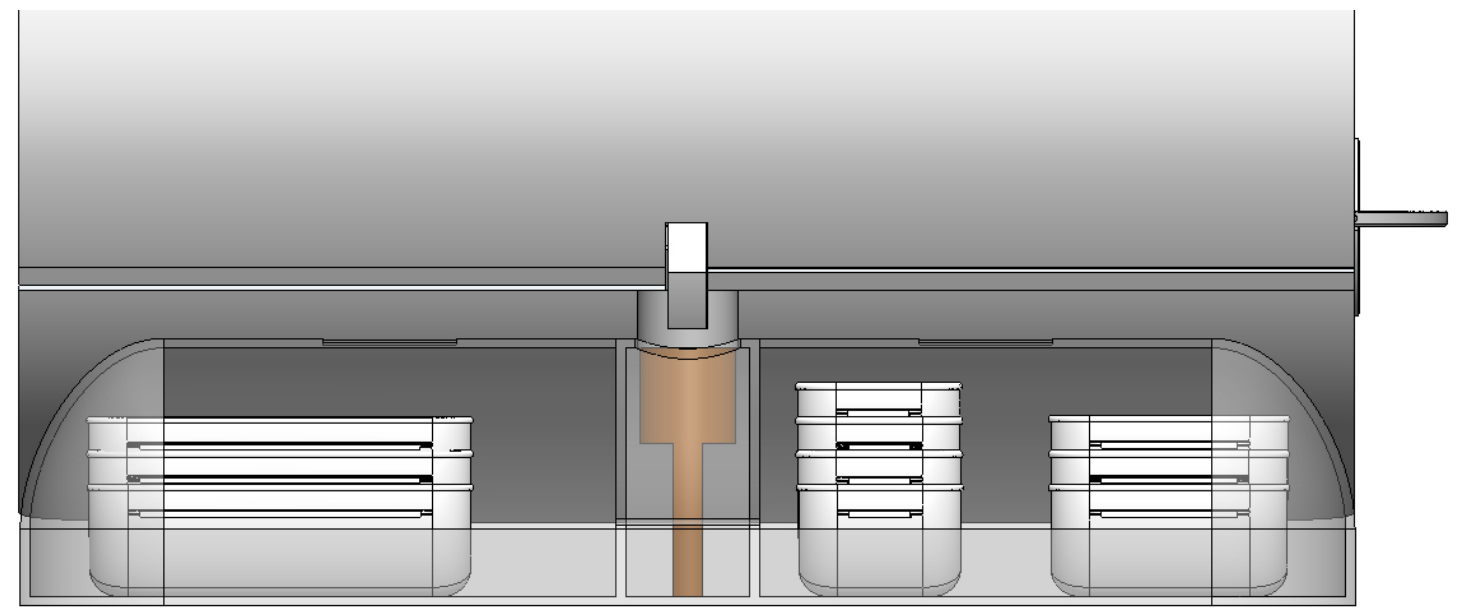

Слика 7.12 Складирање на садовите во просторот од фиоките

\section{6 Лизгачи}

Распоредувањето на садовите за готвење е доста едноставно. Тие се наоѓaат во внатрешноста на стаклената цевка прицврстени на рамка. Рамката располага со два лизгачи прикажани на Слика 7.13, и тоа страничен (1) и горен (2).

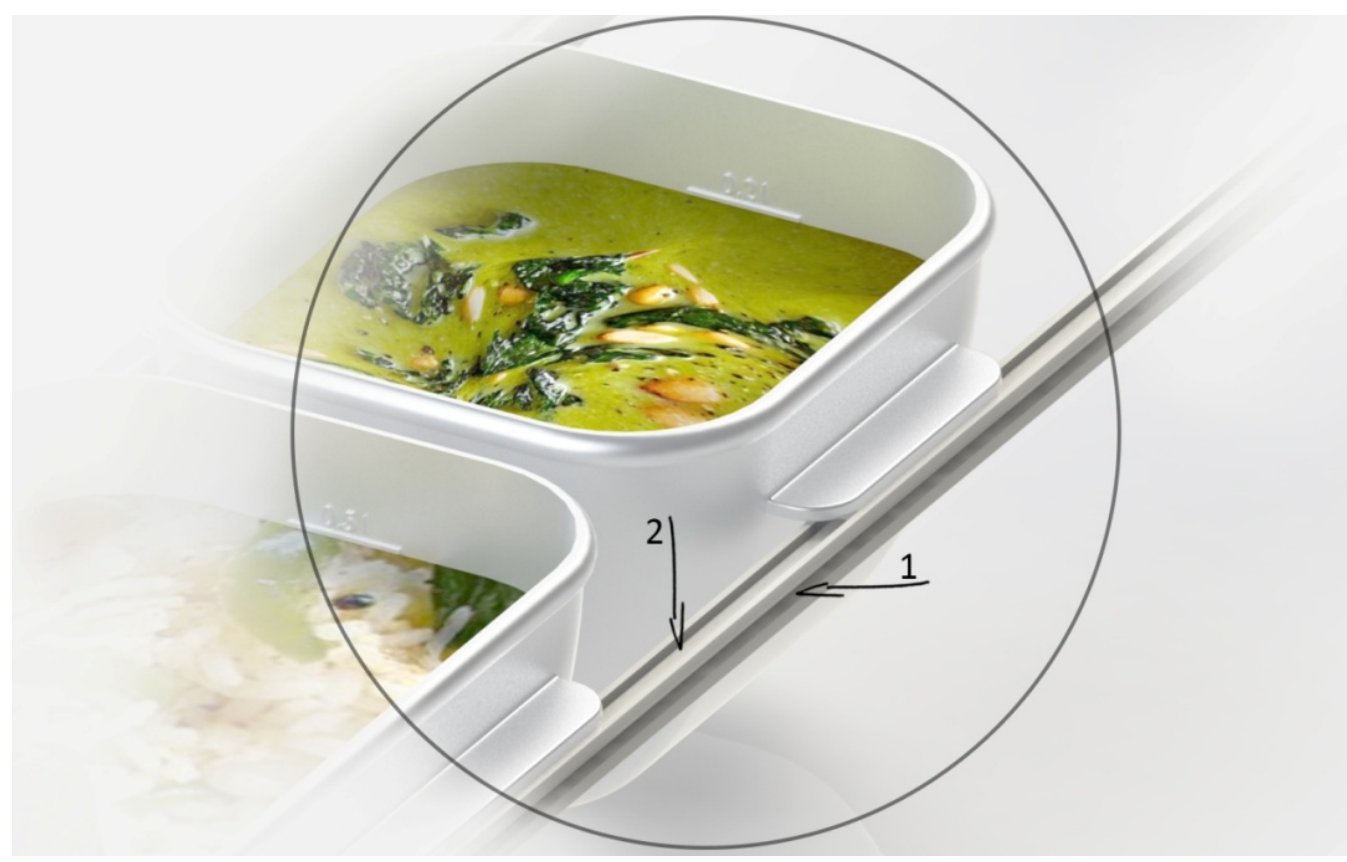

Слика 7.13 Страничен (1) и горен (2) лизгач 
Страничниот лизгач е прицврстен на зидовите од стаклената цевка и овозможува извлекување на целата рамка заедно со сите елементи од внатрешноста и потоа нивно враќање во почетна позиција (Слика 7.14). Горниот лизгач пак овозможува лесно и едноставно прилагодување на позицијата на секој сад посебно, заедно со преградите меѓу нив.
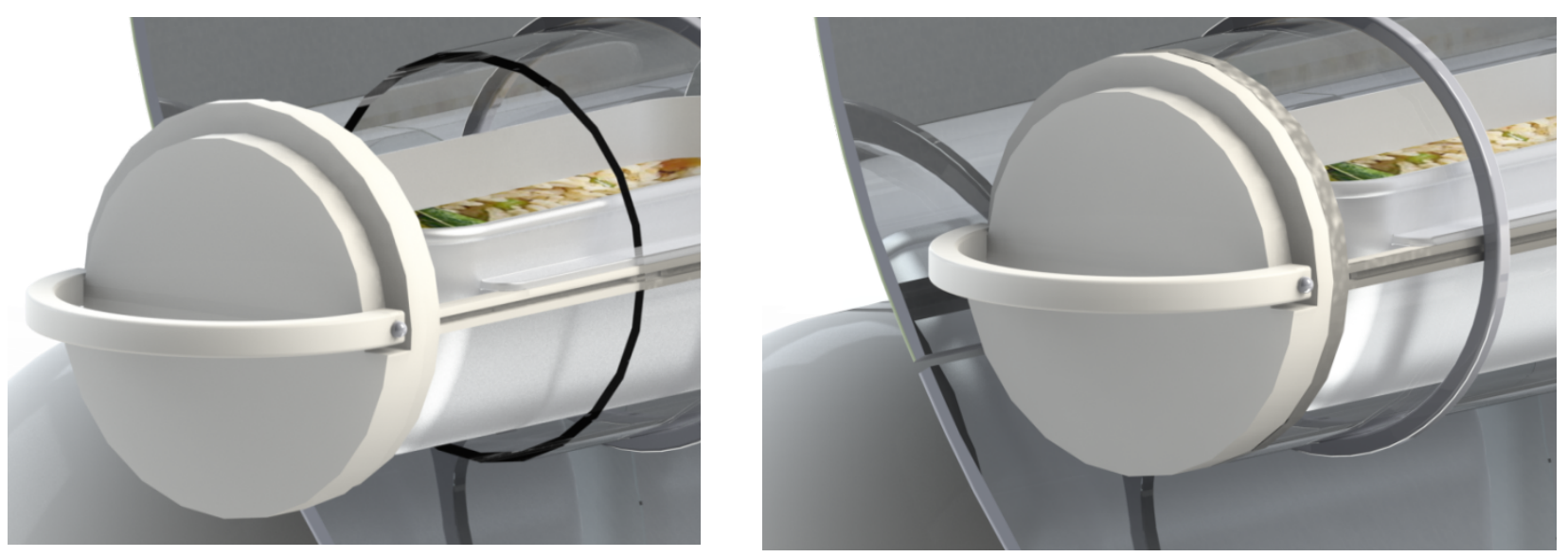

Слика 7.14 Извлекување на елементите од внатрешноста на цевката/зоната на готвење

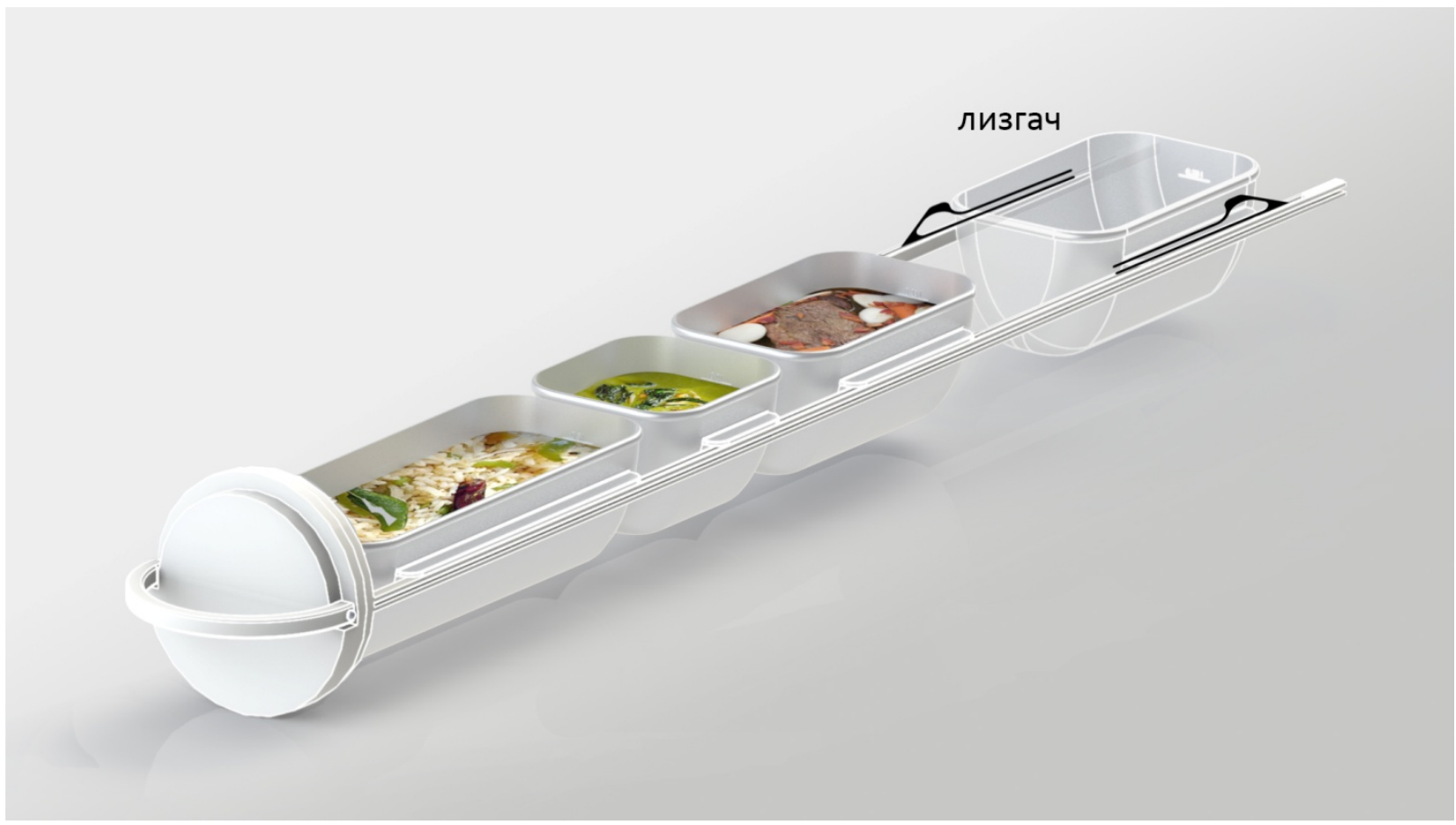

Слика 7.15 Горниот лизгач овозможува променлива и прилагодлива позиција на секој сад 


\section{7 Функционални прегради}

Распоредени по горниот лизгач помеѓу секој од садовите се наоѓаат кружни прегради. Нивната функција е да ги спречат мешањата на мирисите и да овозможат готвење на различни специјалитети истовремено. Како и кај садовите нивната положба по должината на лизгачот е прилагодлива. Овие прегради исто така се практични доколку не се користи целиот капацитет на цевката, односно во одреден момент има потреба од користење на еден или два сада. Тогаш топлиот воздух циркулира во рамките на преградата, во просторот под и над садот, но не и по должината на целата цевка со што се овозможува побрзо загревање.

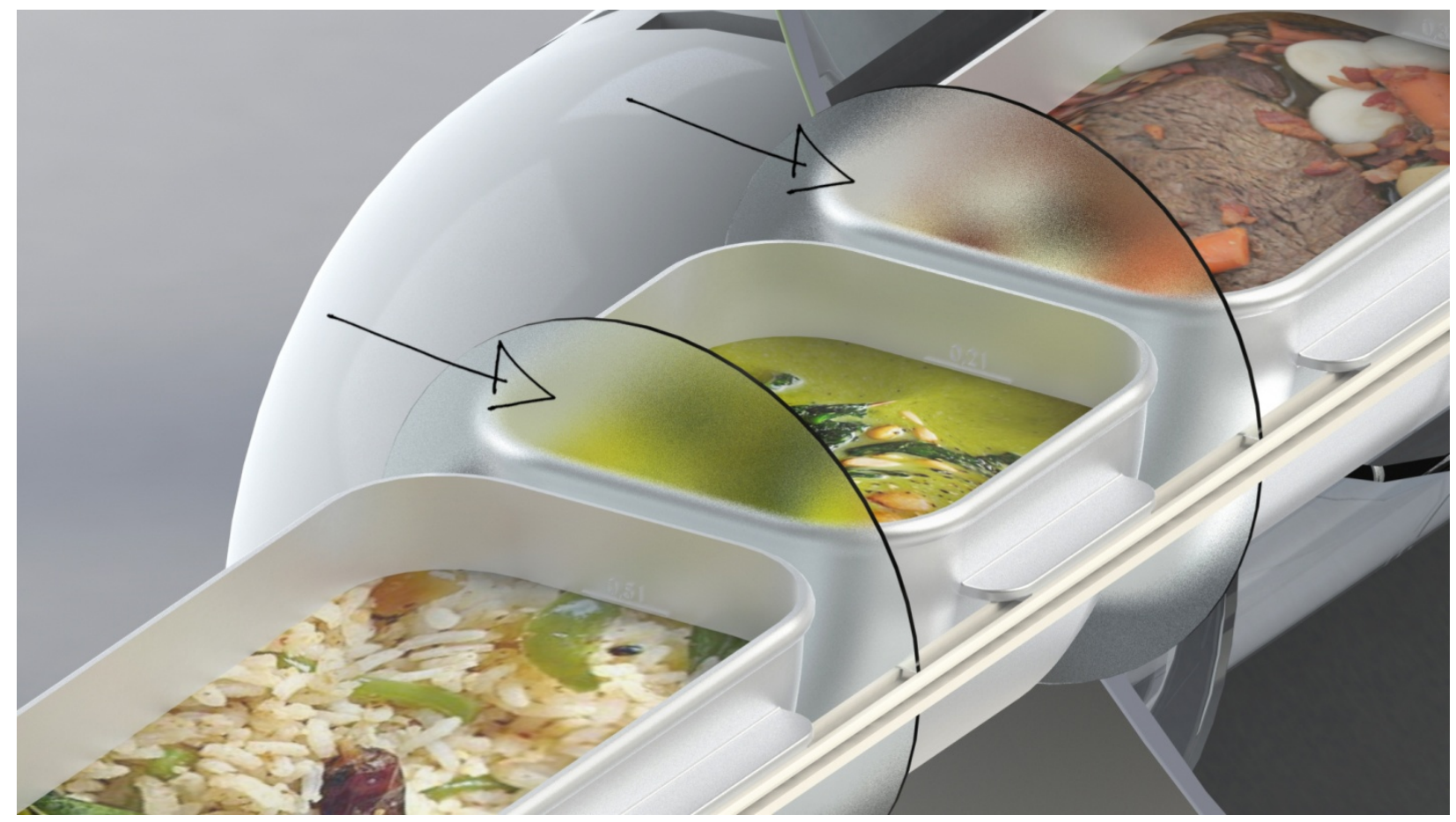

Слика 7.16 Функционални прегради помеѓу секој од садовите 


\section{8 Рачка за извлекување}
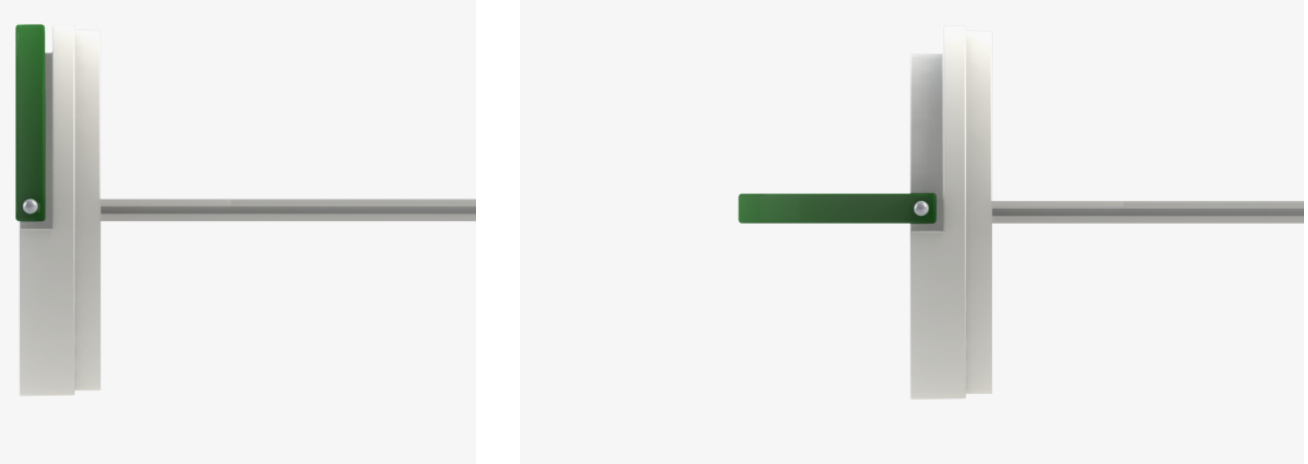

Слика 7.17 Рачка во затворена положба (лево) и рачка во отворена положба (десно)

Рачка со чие повлекување лесно се извлекуваат садовите од внатрешноста. Таа во својата отворена положба се наоѓа надвор од фокусот на рефлектирачката параболична површина и е безбедна за користење. Кога не е во функција (при пренос) се склопува кон страничниот капак од цевката со што станува интегриран дел од него.

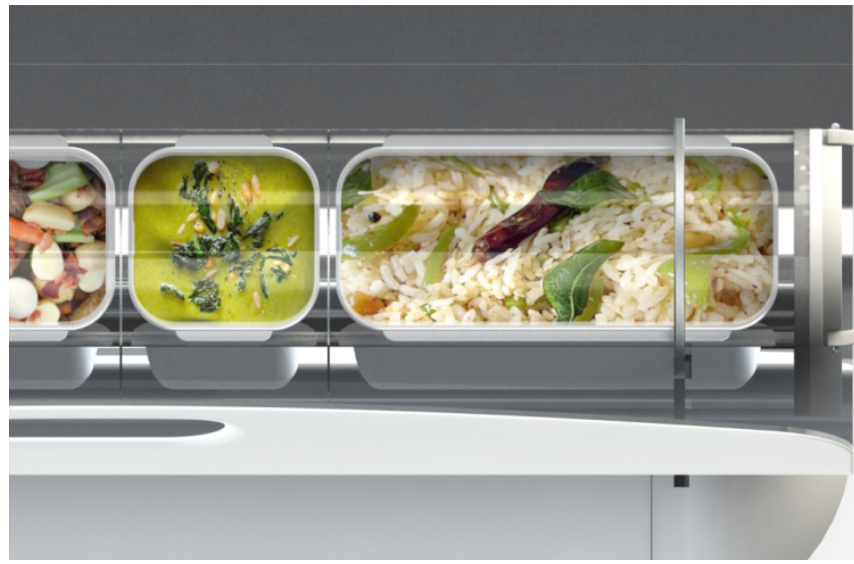

Слика 7.18 Рачката се наоѓa надвор од фокусот на рефлектирачката параболична површина 


\section{9 Садови за готвење и чување на храната}

Предвидени и дизајнирани се 3 големини на садови со капацитет од: 200мл, 330мл и 500мл. Поставени се надолжно по цевката прицврстени на рамка со лизгач која служи како носач. Нивните димензии овозможуваат голем број на комбинации меѓу нив и идеално искористување на просторот за готвење. Што се однесува до формата, странично гледано таа е полукружна, имаат рамно дно и благо заоблен четвртаст облик на горната површина. Долж периметарот на горната површина издаден е раб со жлеб каде навлегува рачката за подигнување. Со ваквиот облик оптимално се вклопуваат и овозможуваат максимално искористување на просторот во зоната за готвење. Иако овие садови првенствено се наменети за готвење, во нив исто така може да чува, транспортира и послужува храната.

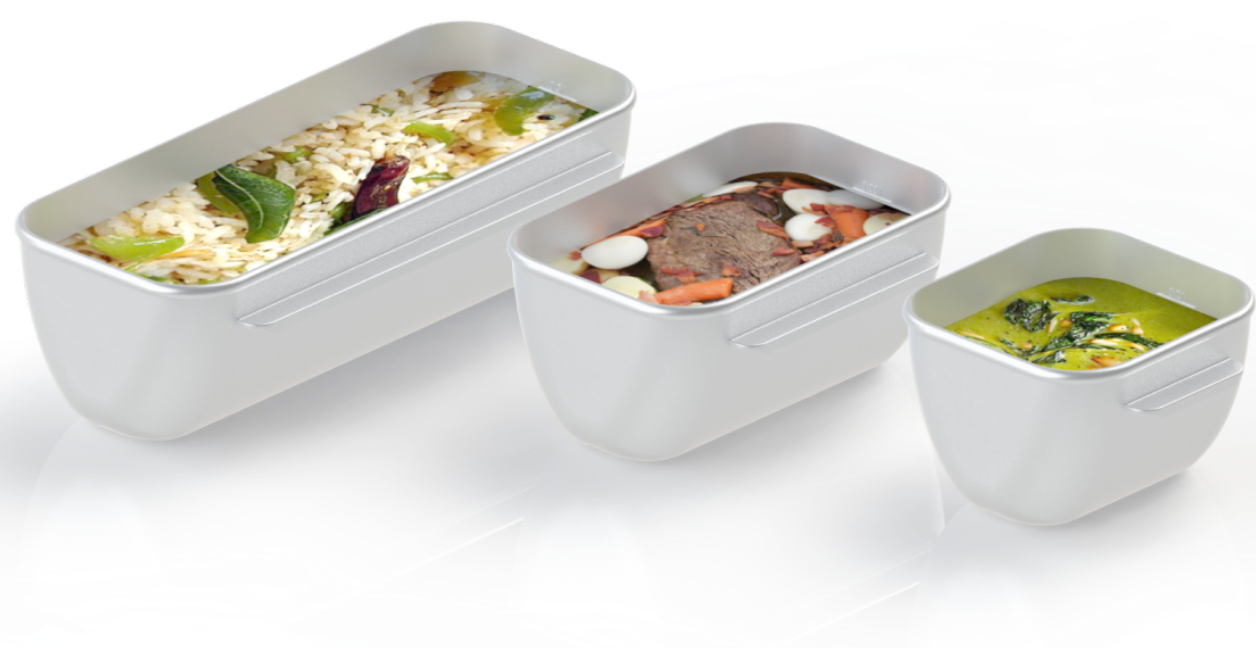

Слика 7.19 Три големини на садовите со капацитет од 200ml, 330ml, 500ml 


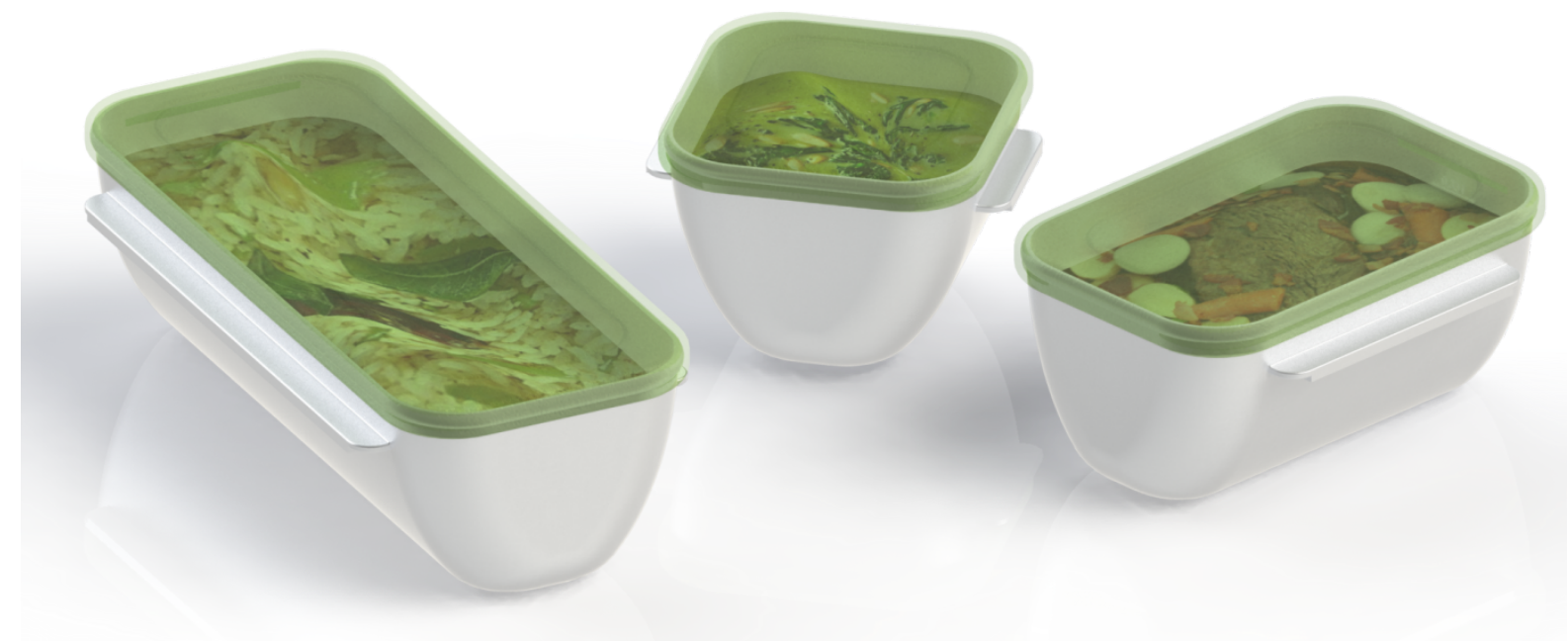

Слика 7.20 Можност за чување и транспортирање на храната

\subsection{0 Комбинации и распоред на садовите}

Распоредот и комбинацијата на садови се мошне значајни, па затоа е важно да се направат правилно, особено кога е потребно максимално искористување на капацитетот и ефикасноста на цевката. Кога зборуваме за комбинација тоа се однесува на утврдување на бројот на садови со различен или ист капацитет кои ќе се најдат во цевката истовремено. Распоредот пак во самата цевка е флексибилен, а го утврдува корисникот. За максимална

ефикасност редоследот на садовите со храна треба да биде таков што ќе почнува со храната на која и треба најмногу време за термичка обработка, а ќе завршува со онаа на која и е потребно најмалку време. При ваков распоред кога процесот е завршен и садот треба да биде изваден од готвачот, рамката со садови само делумно ќе се отвори (извлече) со што нема да дојде до губење на темературата и ладење на останатите садови со храна.

Пример. За максимално искористување на капацитетот на цевката потребна е следната комбинација на садови: 1 х 0,51; 2 х 0,331; 2 х 0,21. Во зависност од потребите комбинацијата може да биде и друга: 2 х 0,33; 4 х 0,21, но тогаш капацитетот е помал. Начинот на кој тие ќе бидат распоредени во цевката (дали садот од 0,51 или 0,331 ќе биде прв или последен) е по избор на корисникот. Ако истовремено во цевката се поставуваат: а.) сад во кој се наоѓa супа и, б.) сад во кој се наоѓа месо, логично е садот со супа да се постави поблиску до отворот за извлекување. 


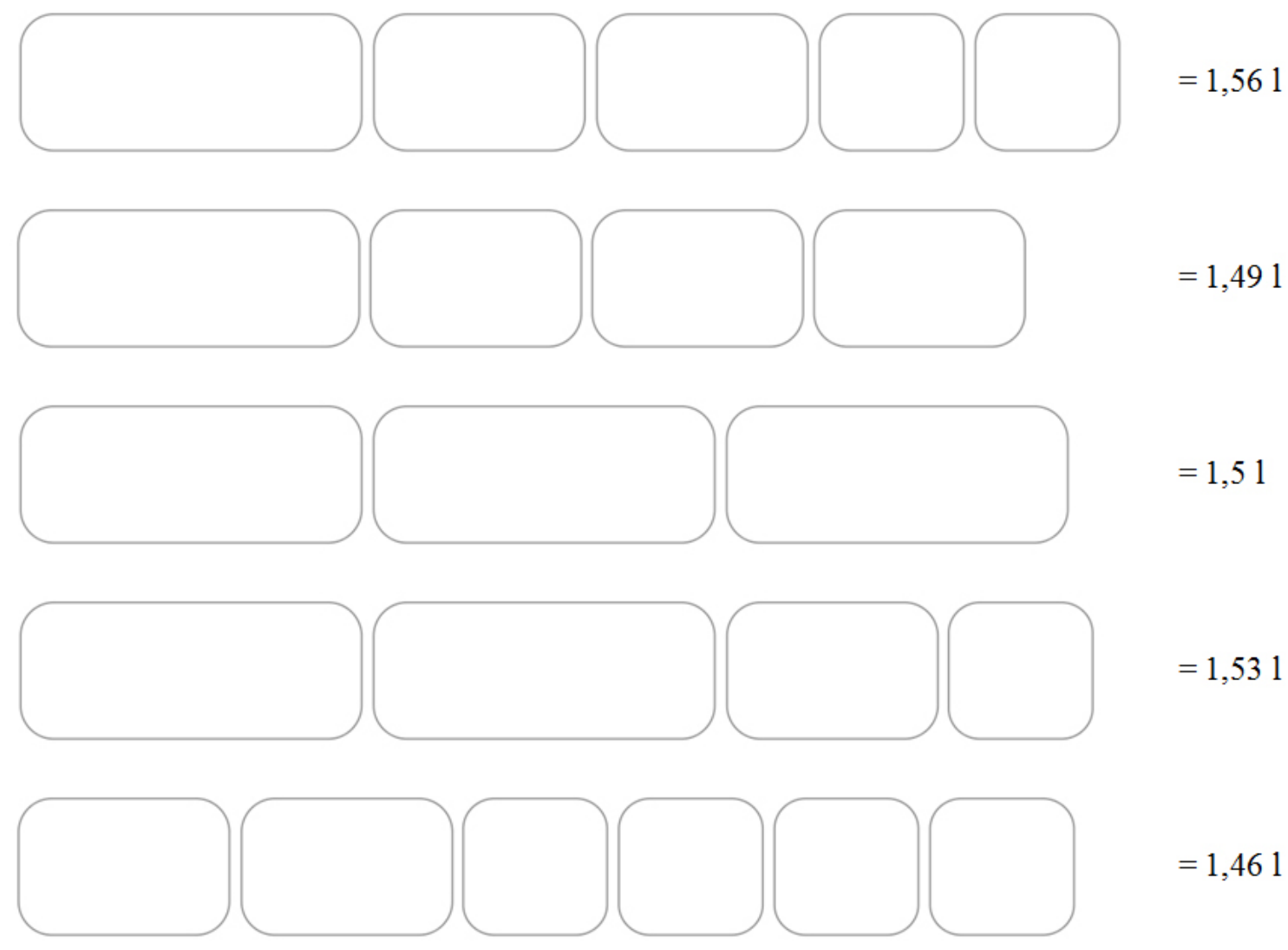

Легенда:

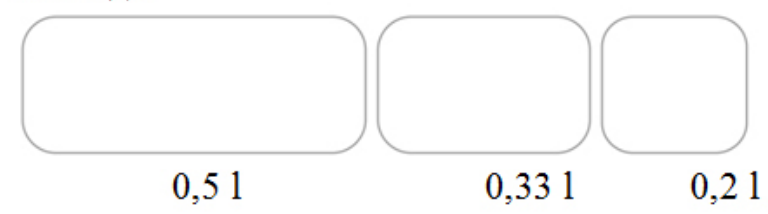

Слика 7.21 Комбинација на садови за максимално искористување на капацитетот на цевката 


\subsection{1 Рачка за подигнување}

Функцијата на оваа рачка е да ги подигне, односно извади садовите од рамката со лизгач. Поради високата температура која се постигнува во цевката, садовите се доста жешки и при несоодветно вадење надвор од готвачот може да дојде до појава на изгореници. Но, и доколку не се загреани, оваа рачка е пожелна и практична поради комапктност и збиеност што се јавува кај садовите во цевката кој пак го отежнува пристапот и манипулацијата со нив.

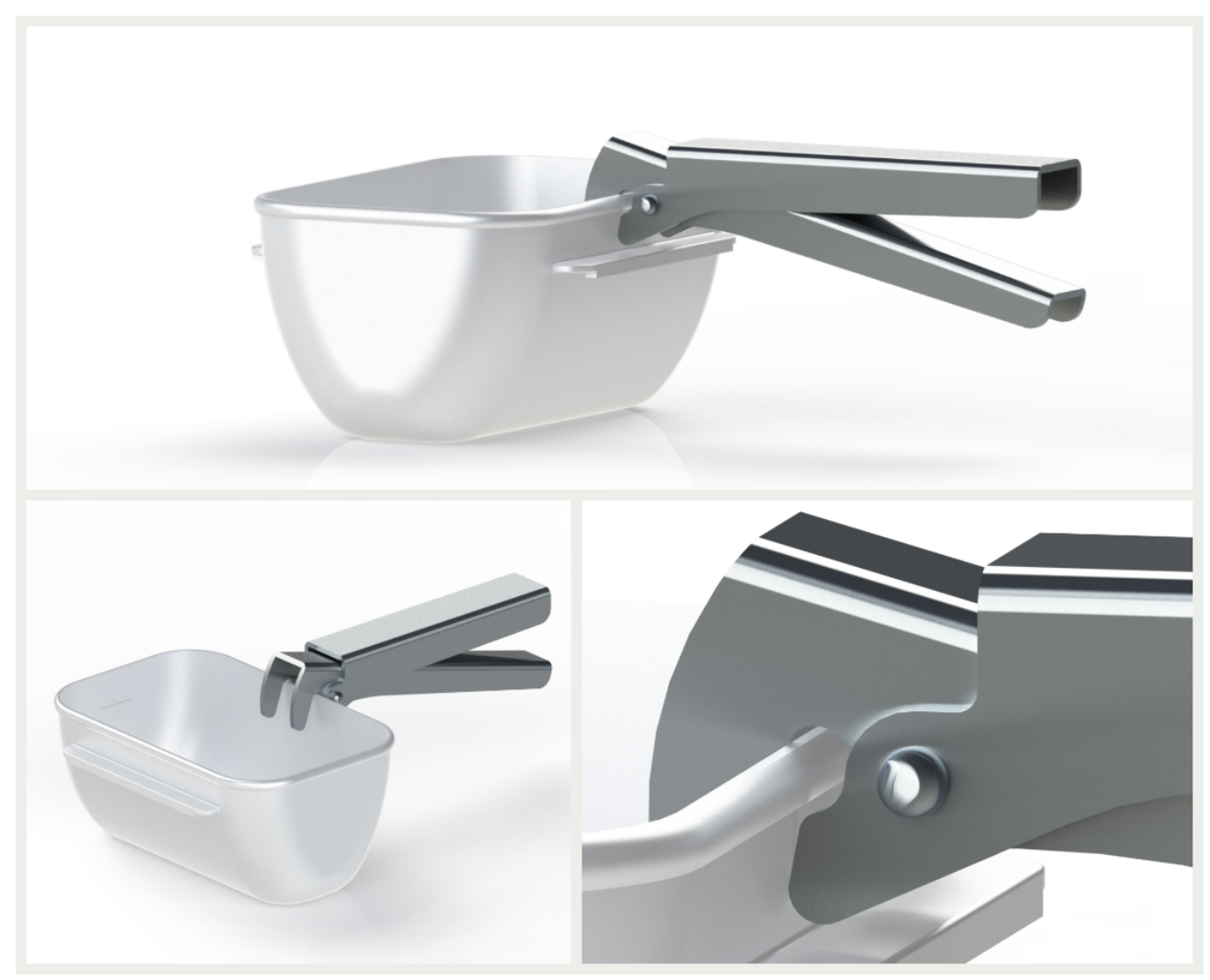

Слика 7.22 Рачка за подигнување на садовите

\subsection{2 Избор на материјали}

Според претходно спроведеното истражување на материјали, нивните својства и карактеристики, како и потребите на производот, се дојде до следниот избор на материјали, а тоа се:

Рефлектирачка параболична повриина: полиран анодизиран алуминиум

Цевка: калено стакло

Конструкција: легура на алуминиум

Садови: емајлиран челик или алуминиум 


\subsection{3 Технички иртежи}

Технички цртеж претставува основна подлога или документ за изработка, контрола и склопување (монтажа) на некој технички објект и склоп од технички објекти, како и за нивна експлотација и одржување.

Техничките цртежи во однос на начинот на прикажување се делат на ${ }^{46}$ :

- Ортогонален цртеж - претставува основен начин на претставување на објектите во машинството. Објектот се претставува во толку ортогонални проекции или погледи, колку што се доволни за создавање на просторна претстава за истиот;

- Просторен цртеж - објектите ги прикажува во просторна или тродимензионална форма
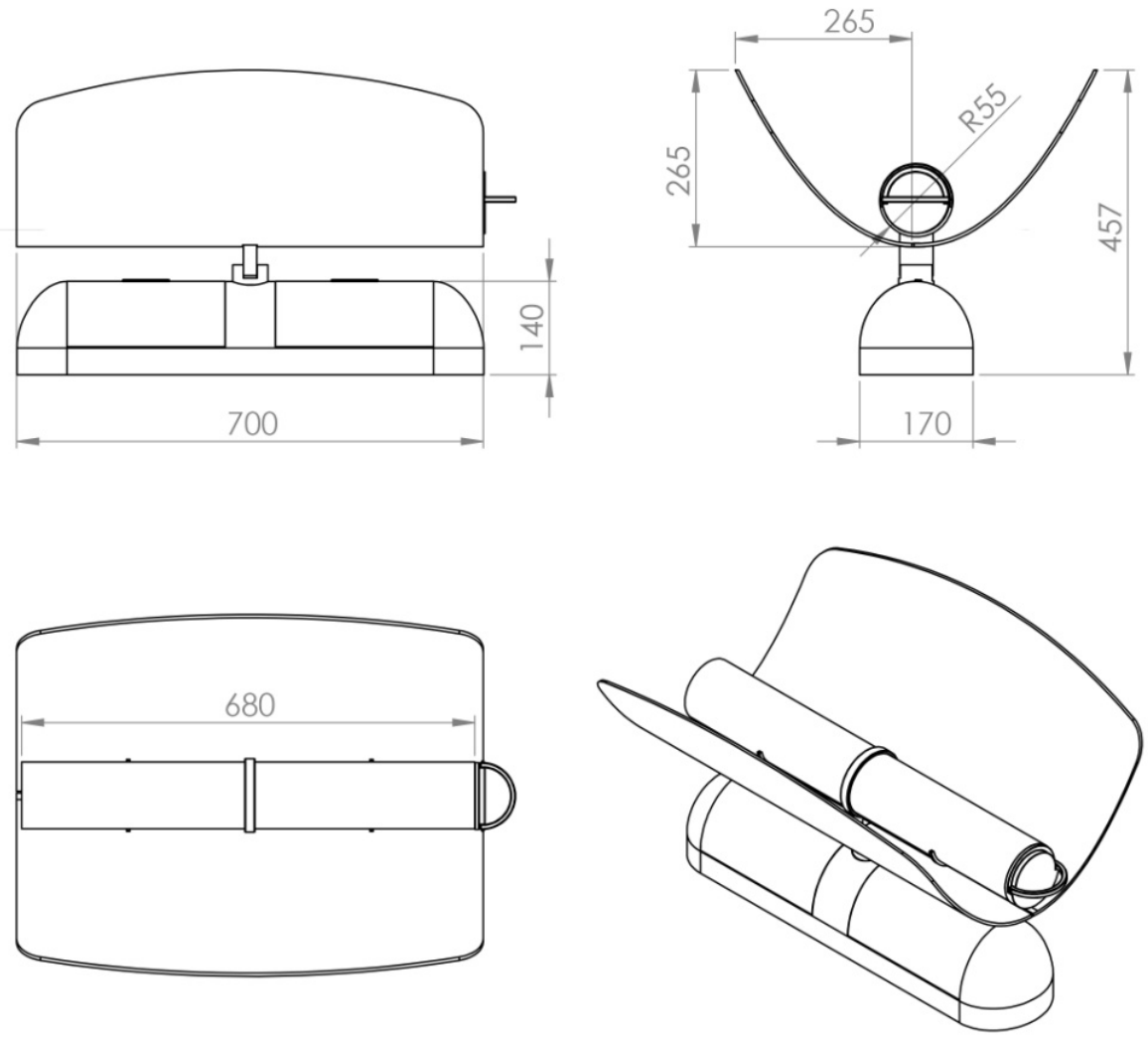

Цртеж 7.1 Основни димензии на склопен цртеж на уредот

\footnotetext{
46 Ташевски Ристо, Инженерска графика, 2004
} 

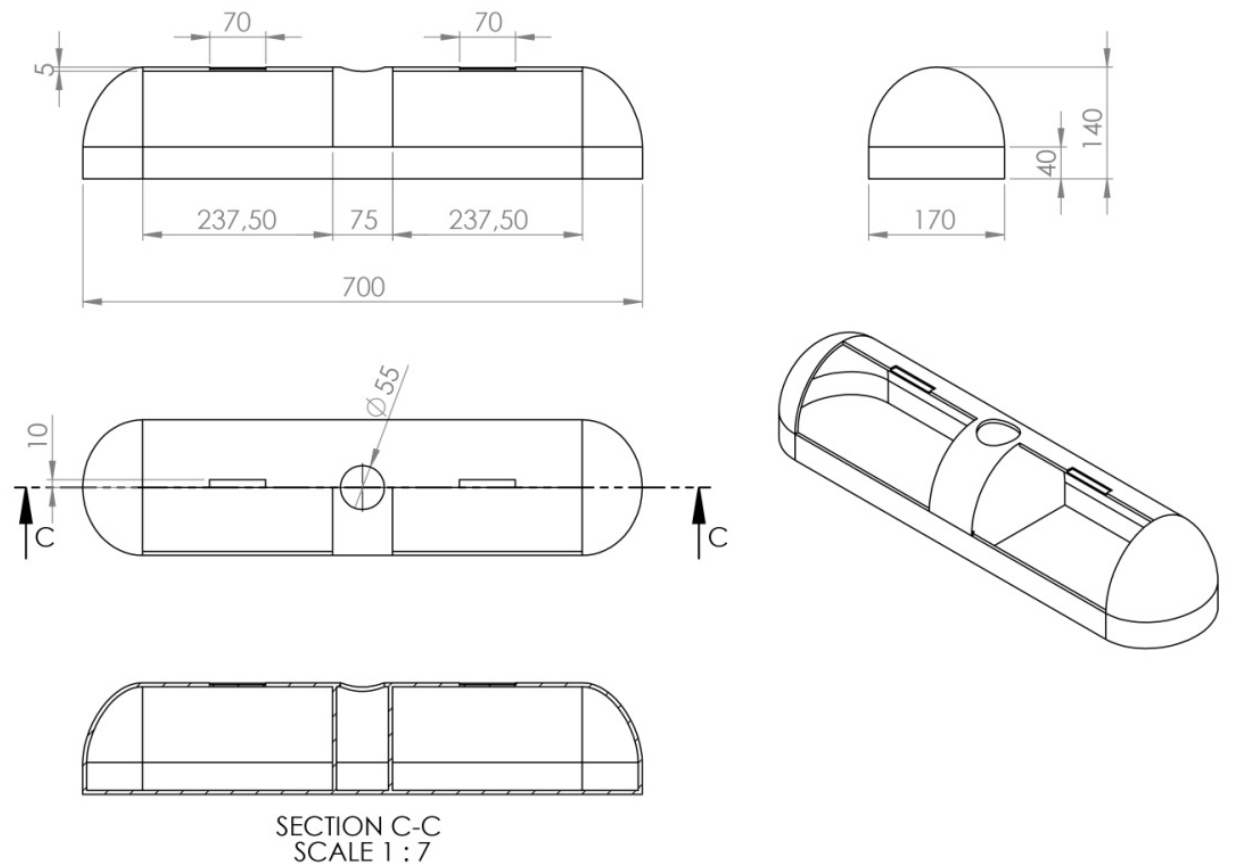

Цртеж 7.2 Основни димензии на основата на уредот
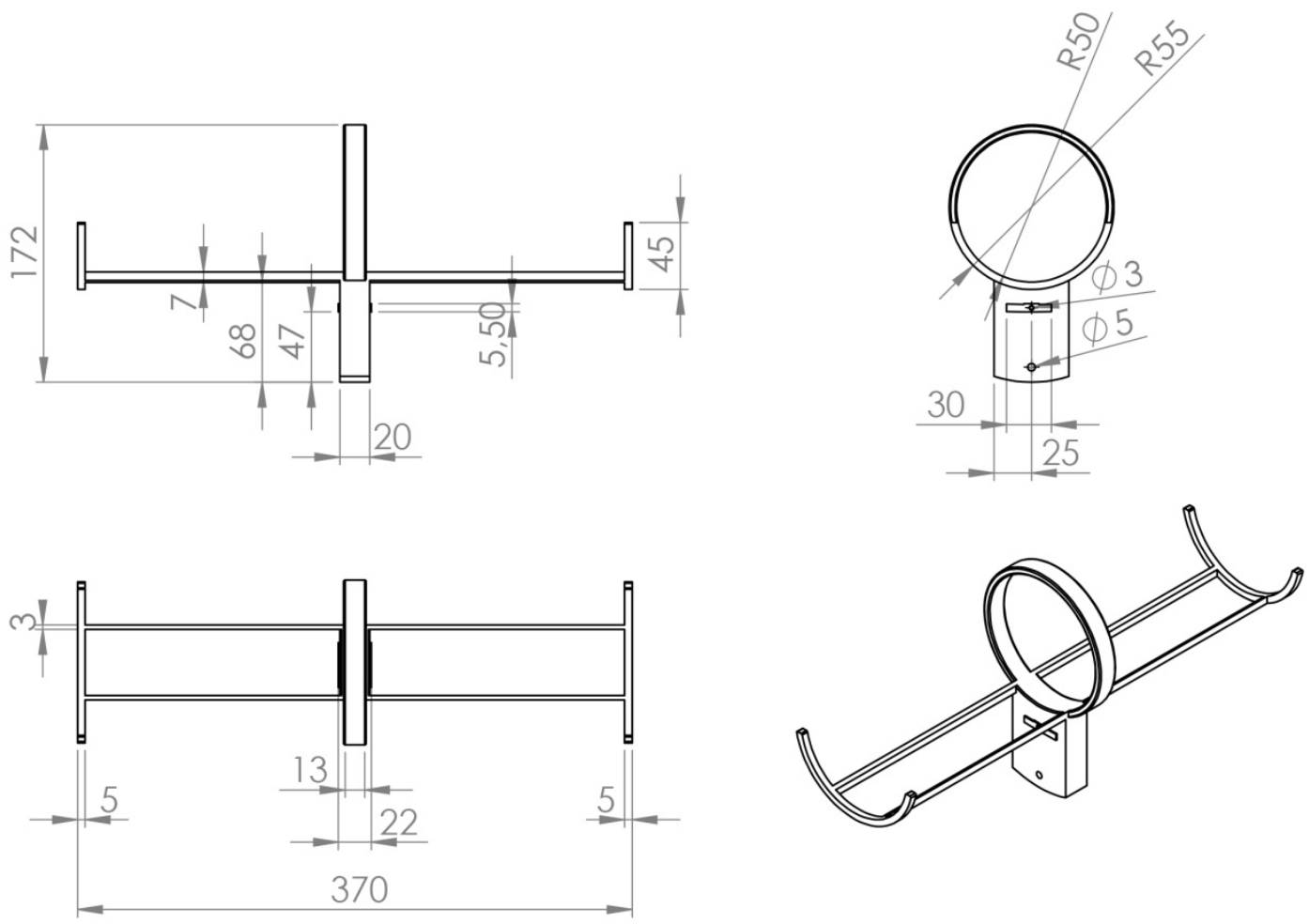

Цртеж 7.3 Основни димензии на прстенест држач и носечка конструкција на цевка 

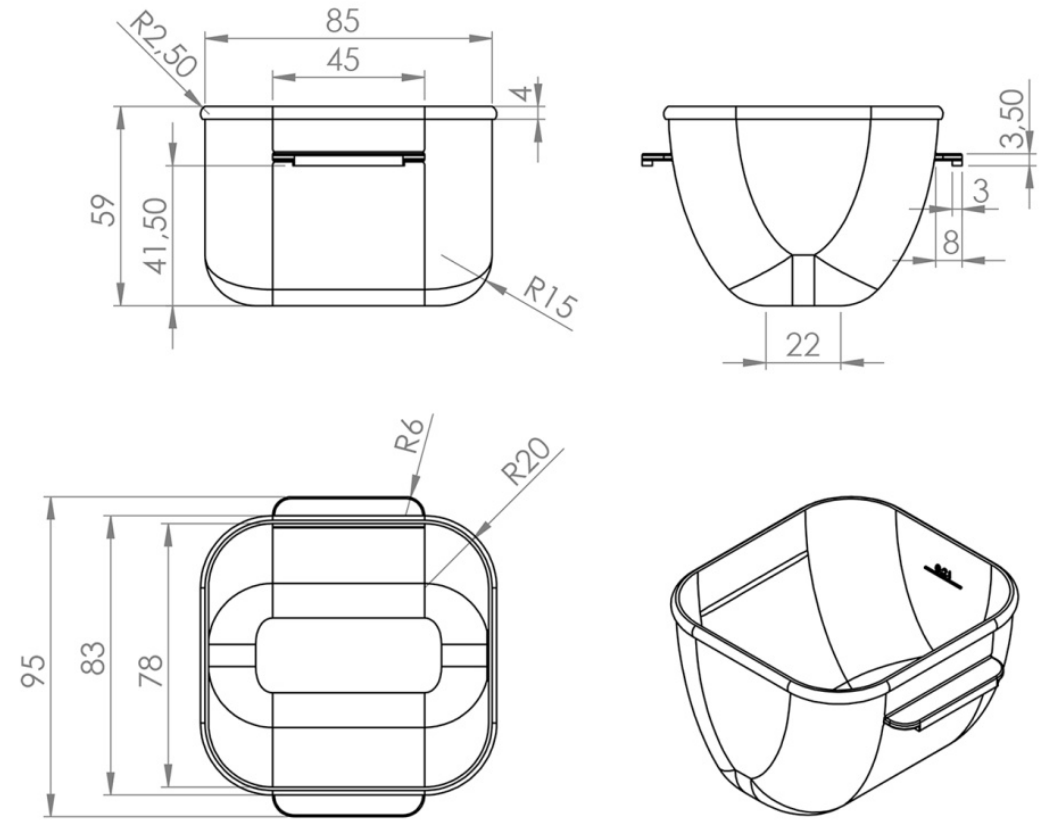

Цртеж 7.4 Основни димензии на сад 200мл
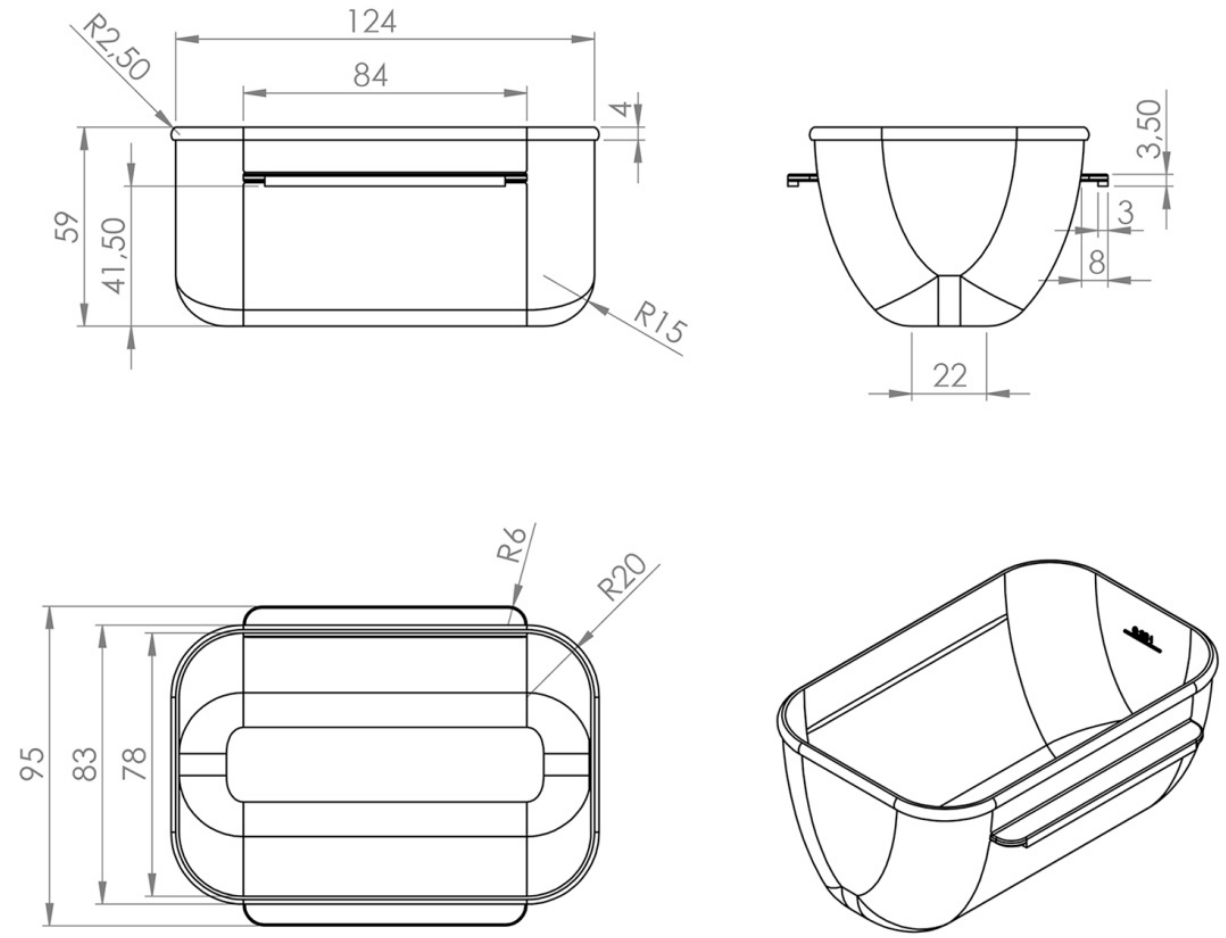

Цртеж 7.5 Основни димензии на сад 330мл 

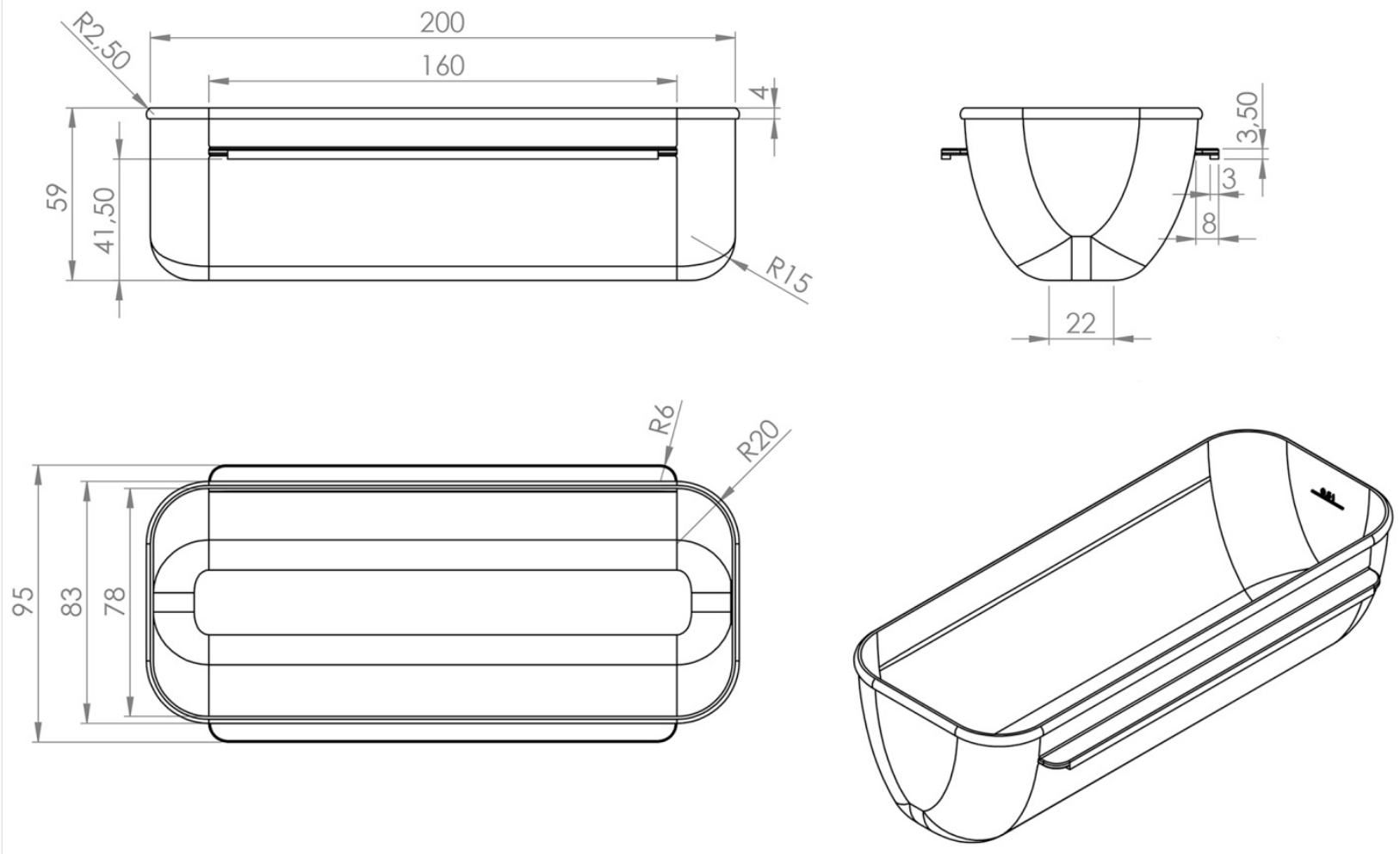

Цртеж 7.6 Основни димензии на сад 500мл 


\subsection{D визуелизација}

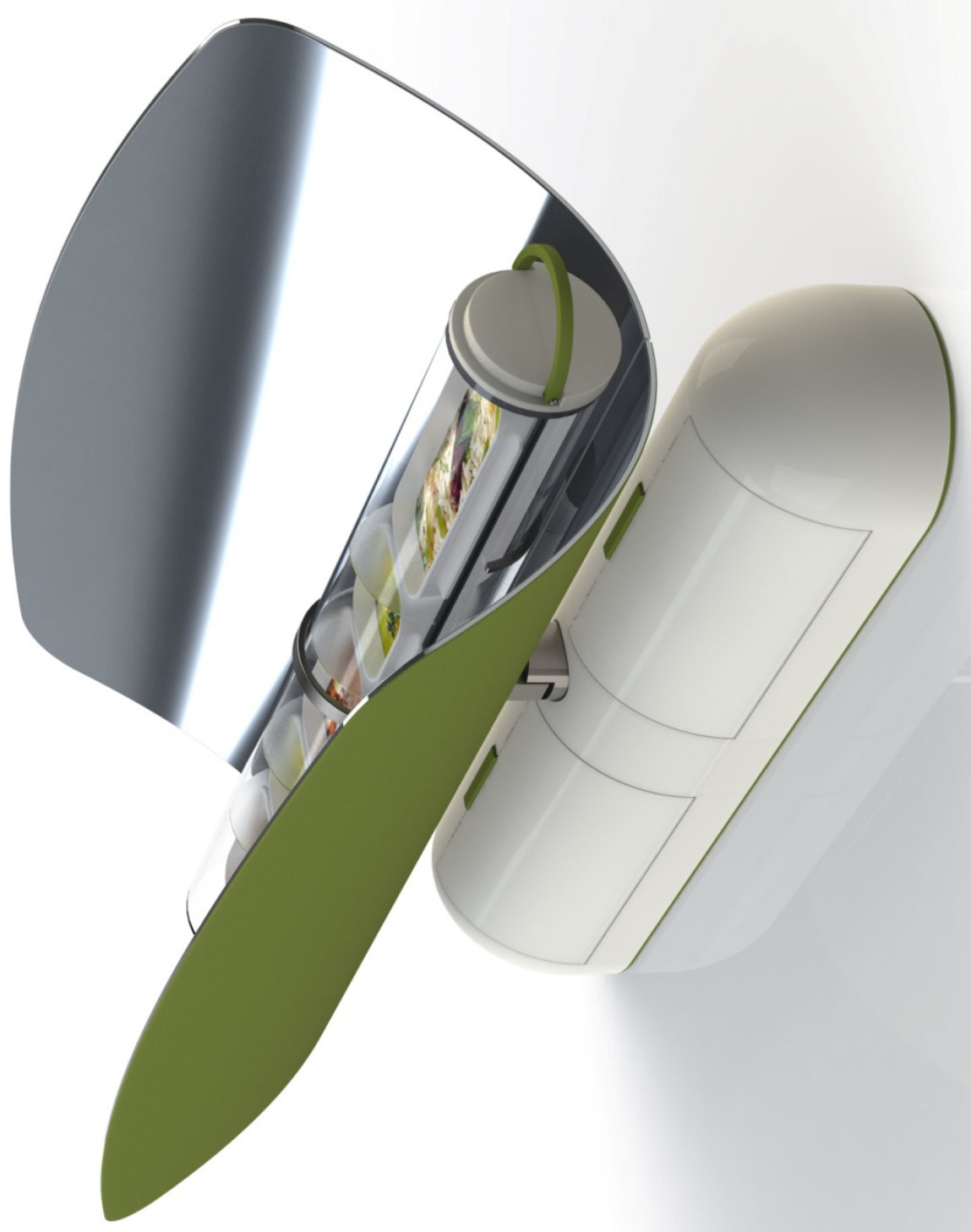




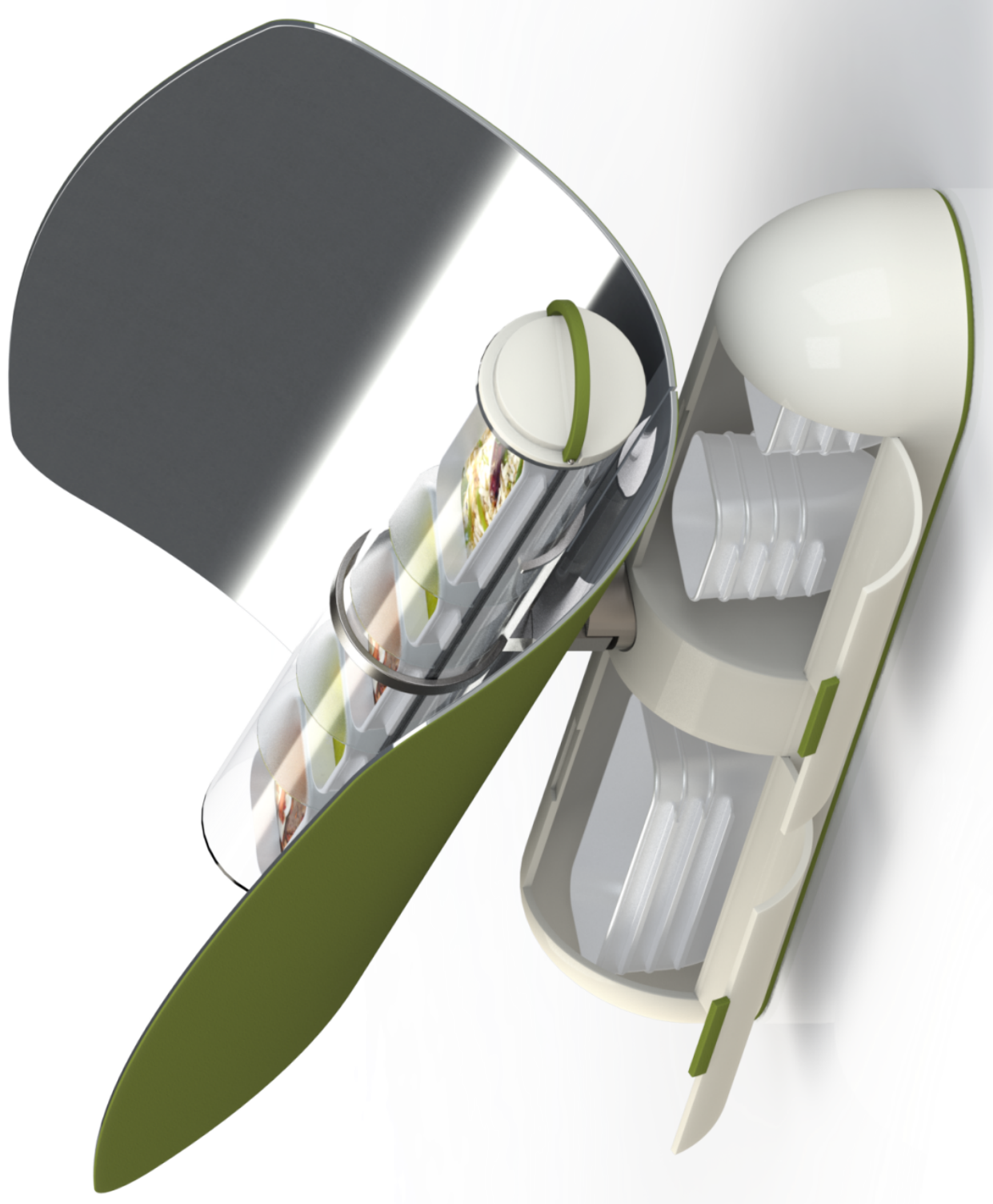




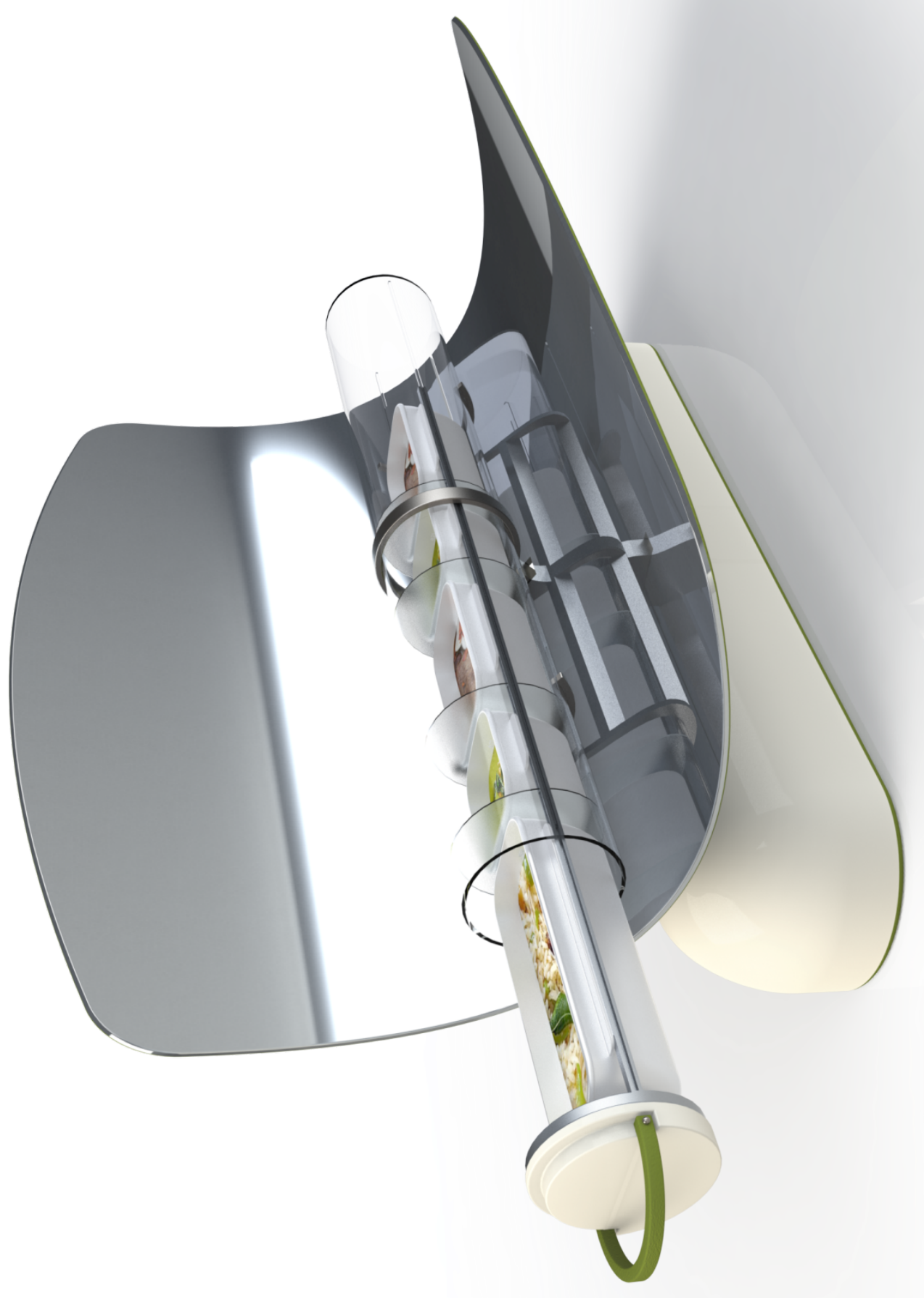




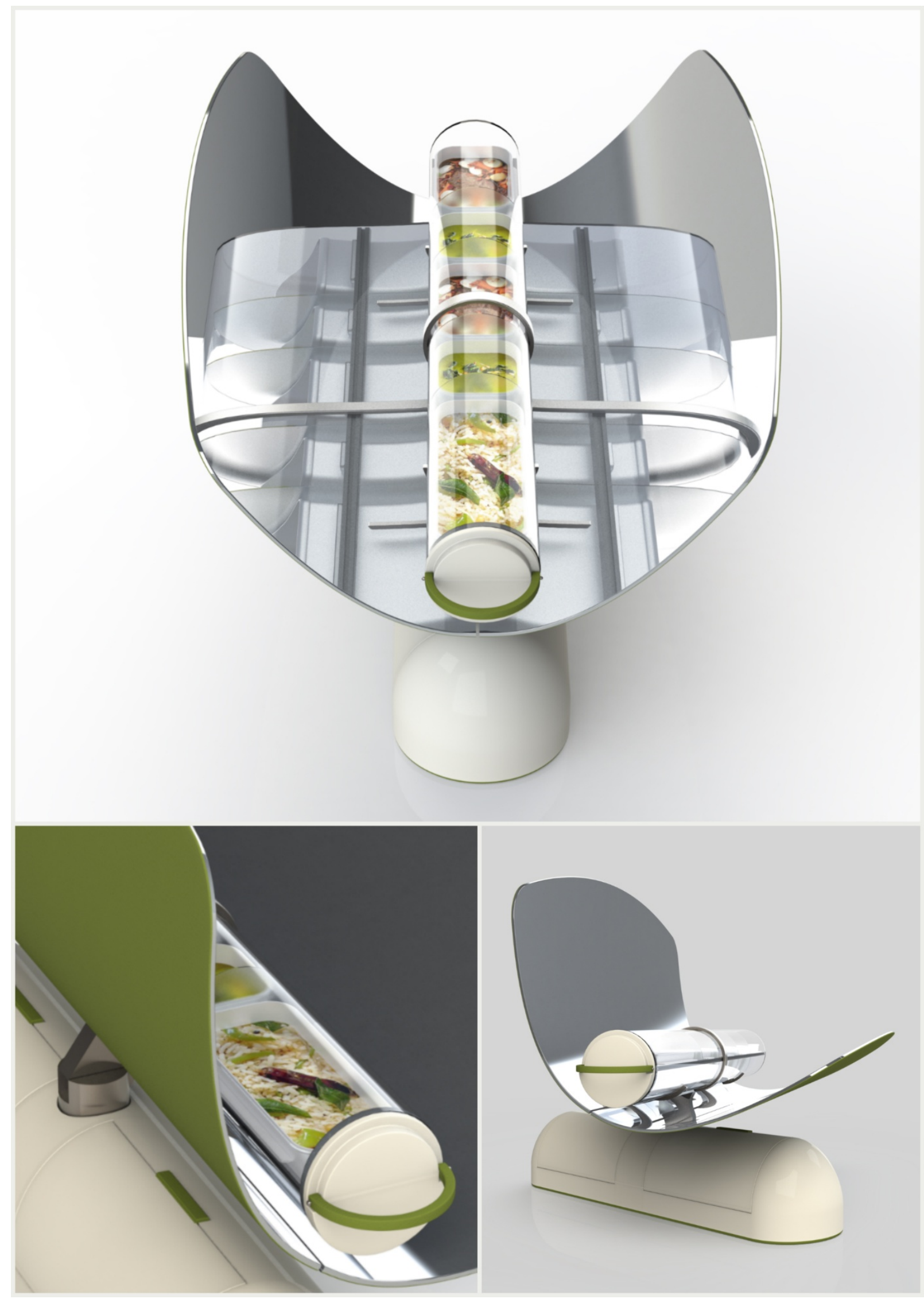




\section{8. Анализа на концептот}

Со оглед на тоа дека не станува збор за објект кој завзема статична позиција, туку динамичен уред кој го следи движењето на Сонцето постојано, потребно е да се направат испитувања кои ќе ни ја покажат оптималната позиција на поставеност во одредени часовни периоди во текот на денот, за одреден период од годината, на определена локација. За таа цел ЗД моделот на уредот се импортира во програмскиот пакет Ecotect Analysis каде ќе се извршат потребните анализи.

Како пример за илустрација при спроведувањето и разработката на анализата за оптималната ориентација беше земен 21 јуни, најдолгиот ден во годината на северната хемисфера, со местоположба Скопје. Резултати од анализата се претставени на стетографиски дијаграми, каде е прикажана позицијата на Сонцето во 10 часот (Дијаграм 8.1), 12 часот (Дијаграм 8.2) и 17 часот (Дијаграм 8.3). Преку нив визуелно јасно се гледа движењето на Сонцето во зависност од часовниот период во текот на денот и поставеноста на уредот (прикажан како црвен објект) секогаш нормално на сончевите зраци.

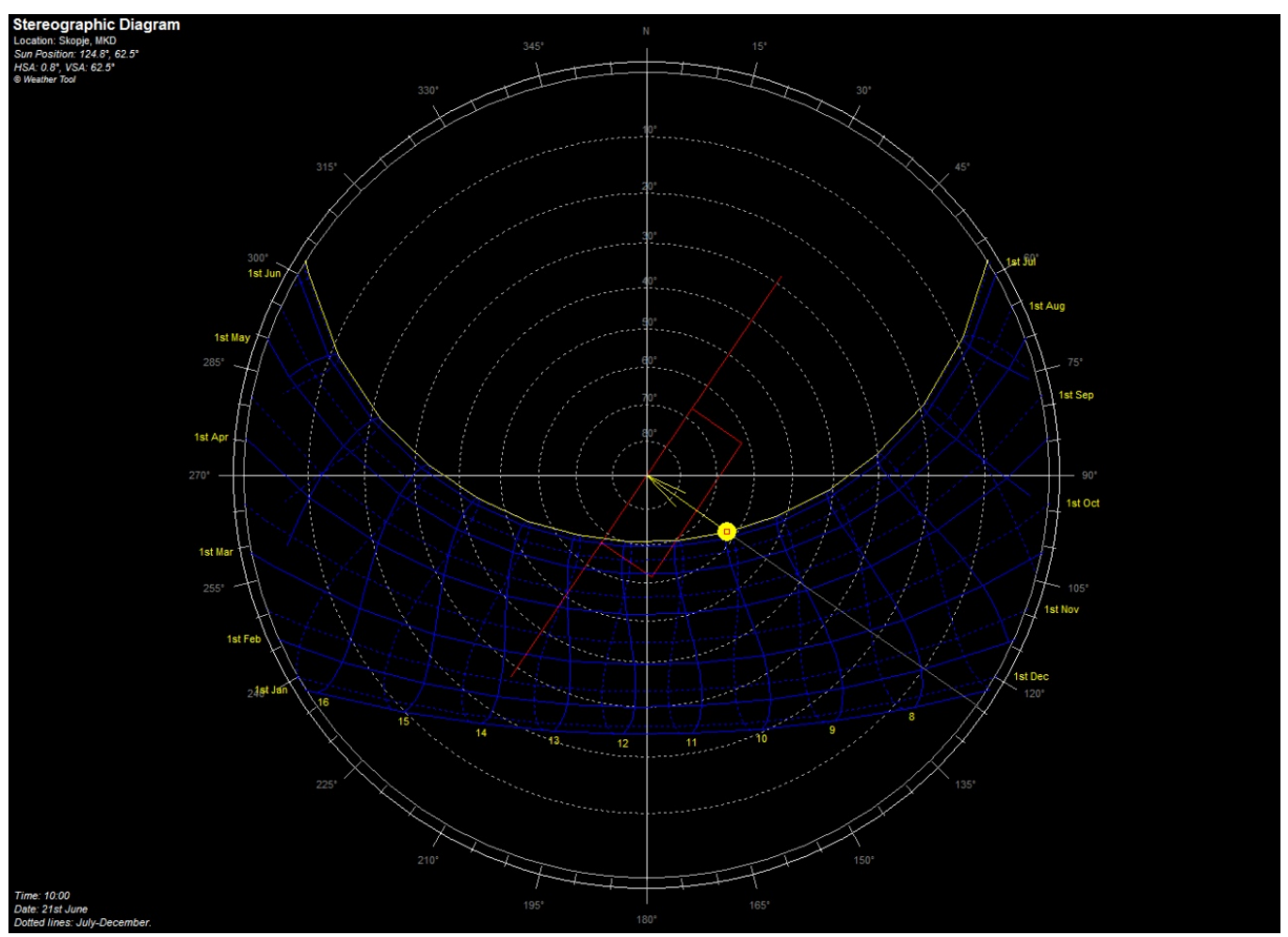

Дијаграм 8.1 Одредување на оптимална ориентација, Скопје, 21 јуни, 10 часот 


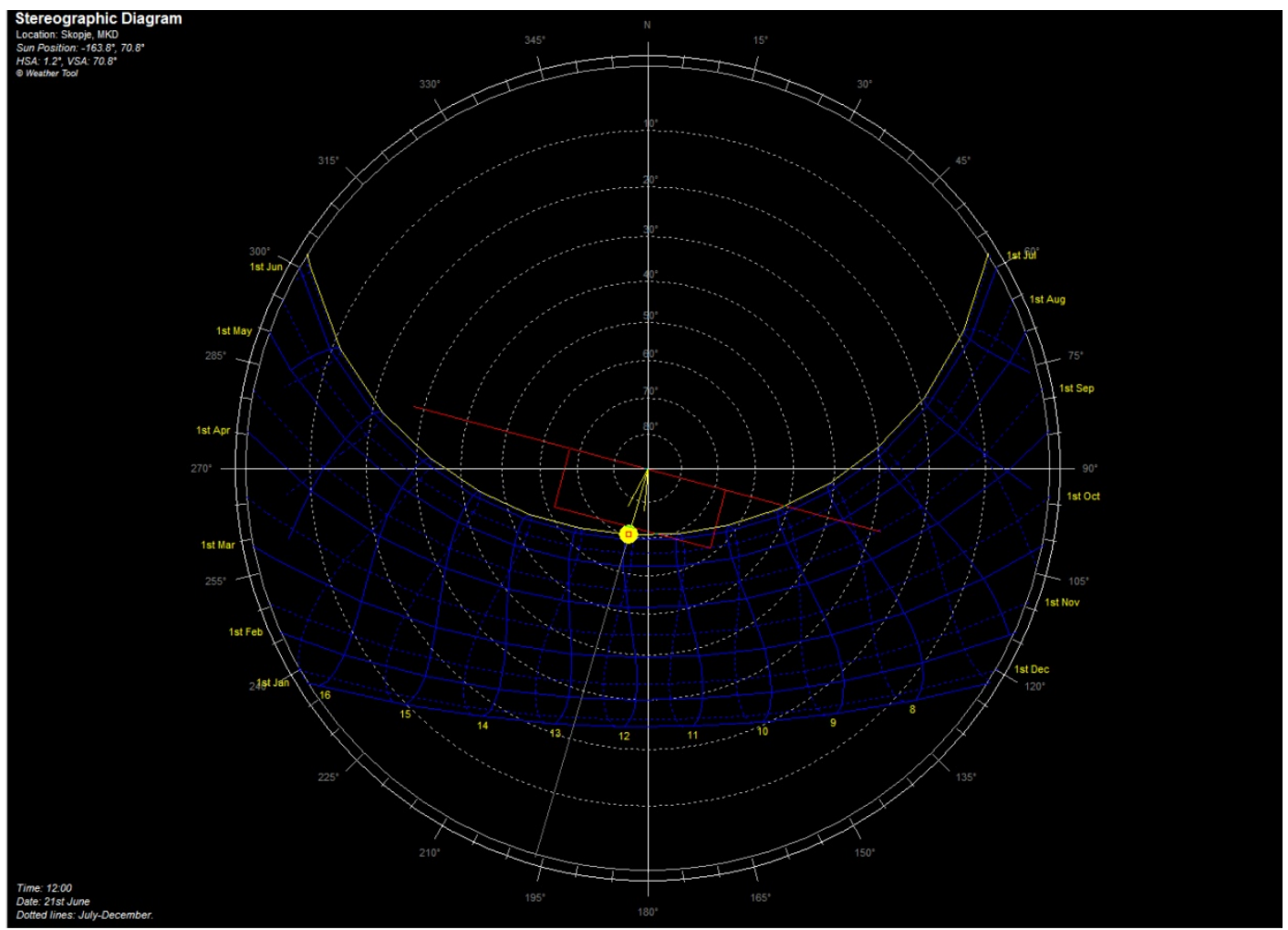

Дијаграм 8.2 Одредување на оптимална ориентација, Скопје, 21 јуни, 12 часот

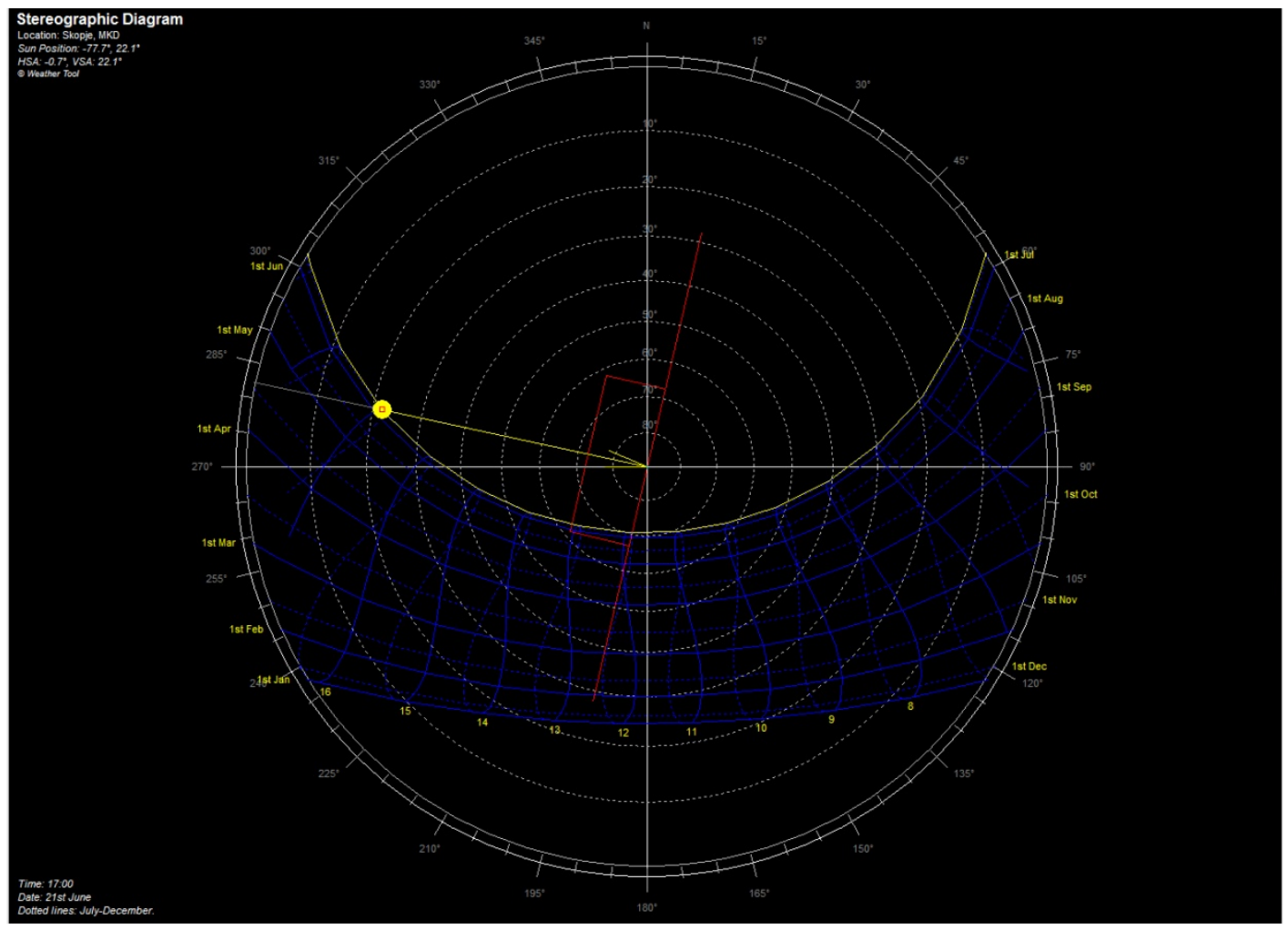

Дијаграм 8.3 Одредување на оптимална ориентација, Скопје, 21 јуни, 17 часот 


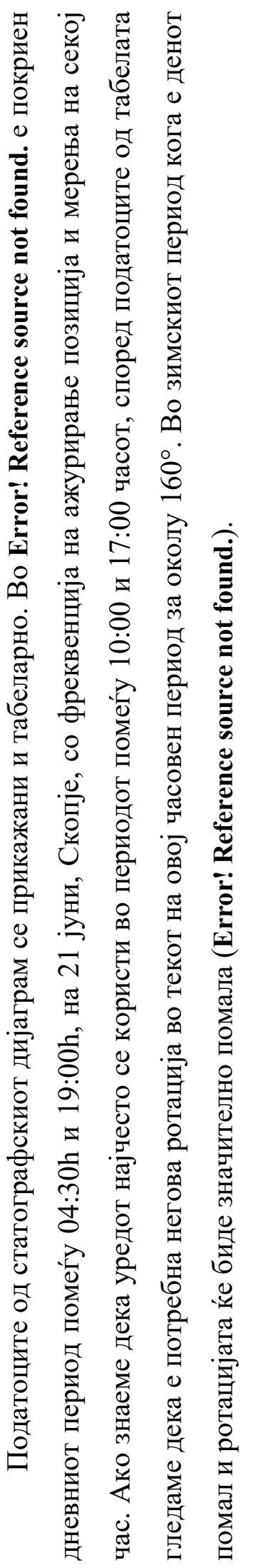

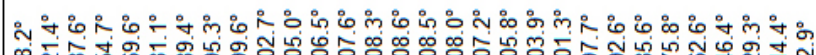

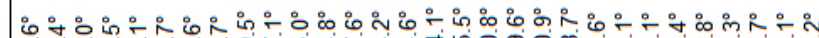

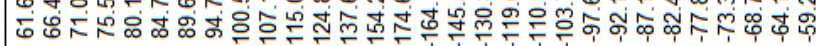

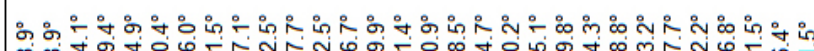
독듀용 to

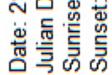

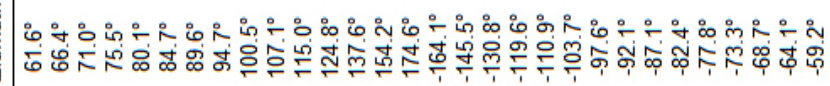

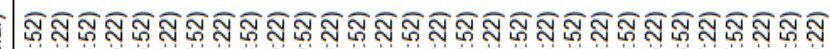

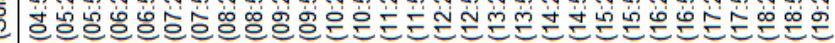



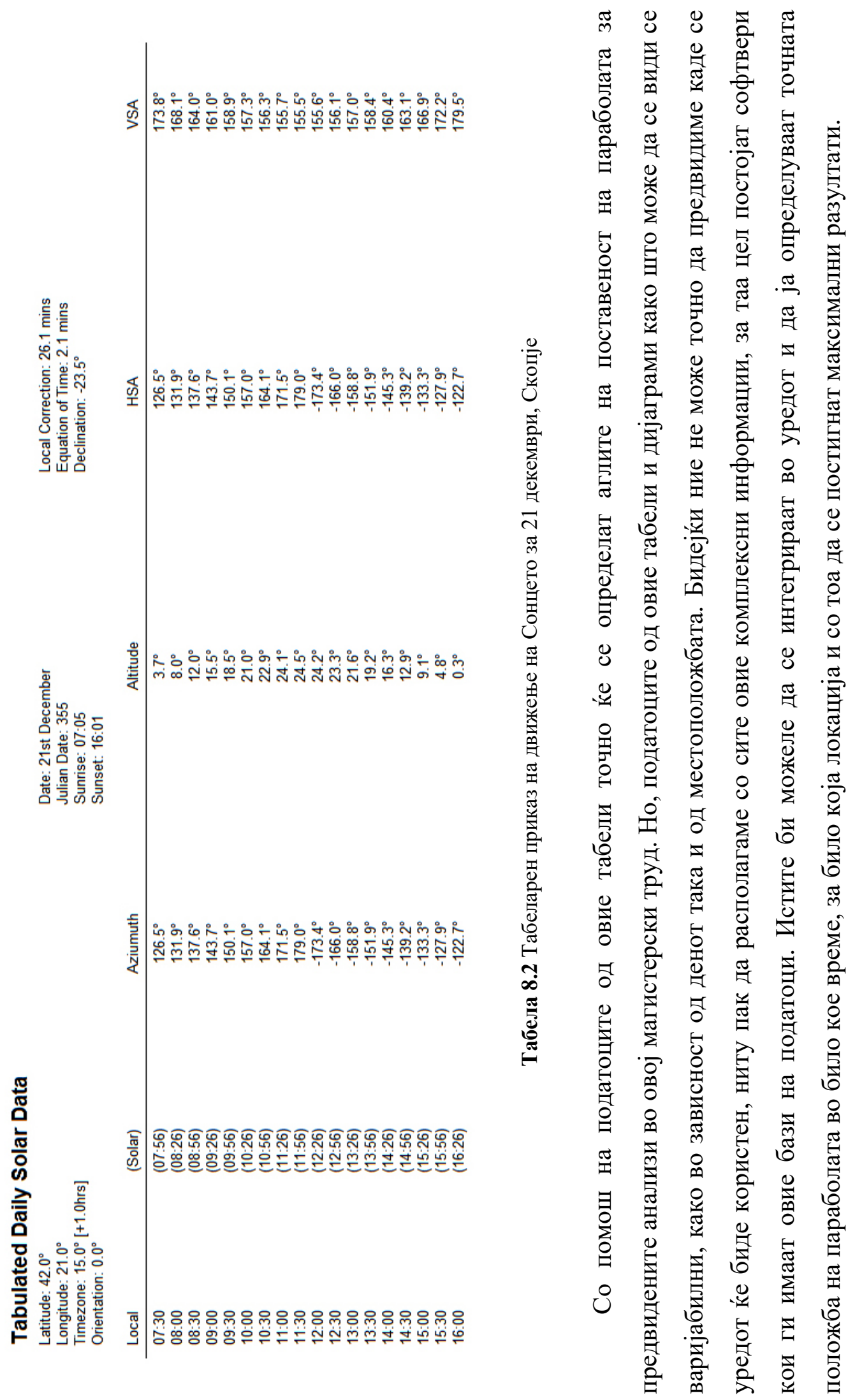

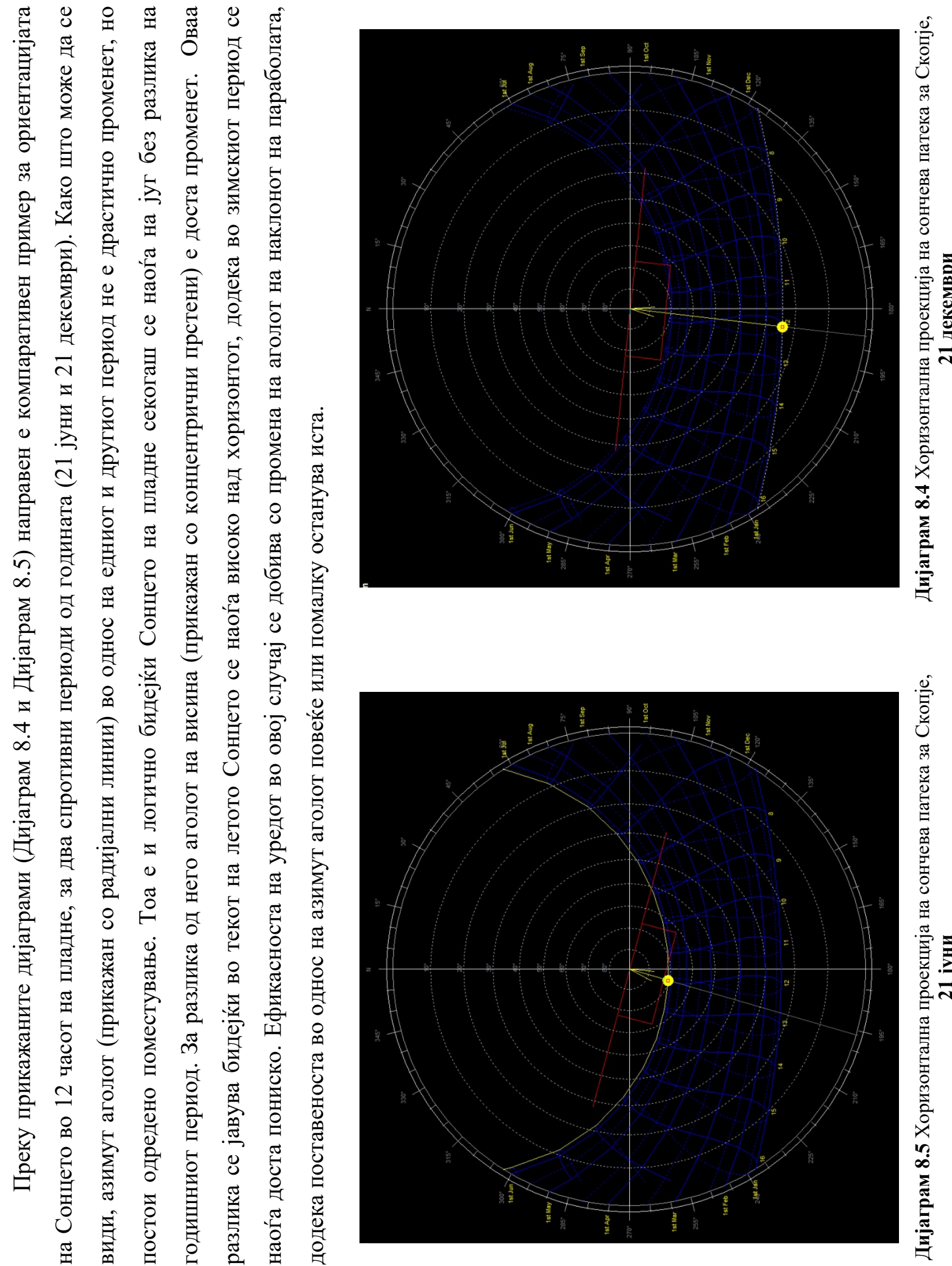

МАГИСТЕРСКИ ТРУД 


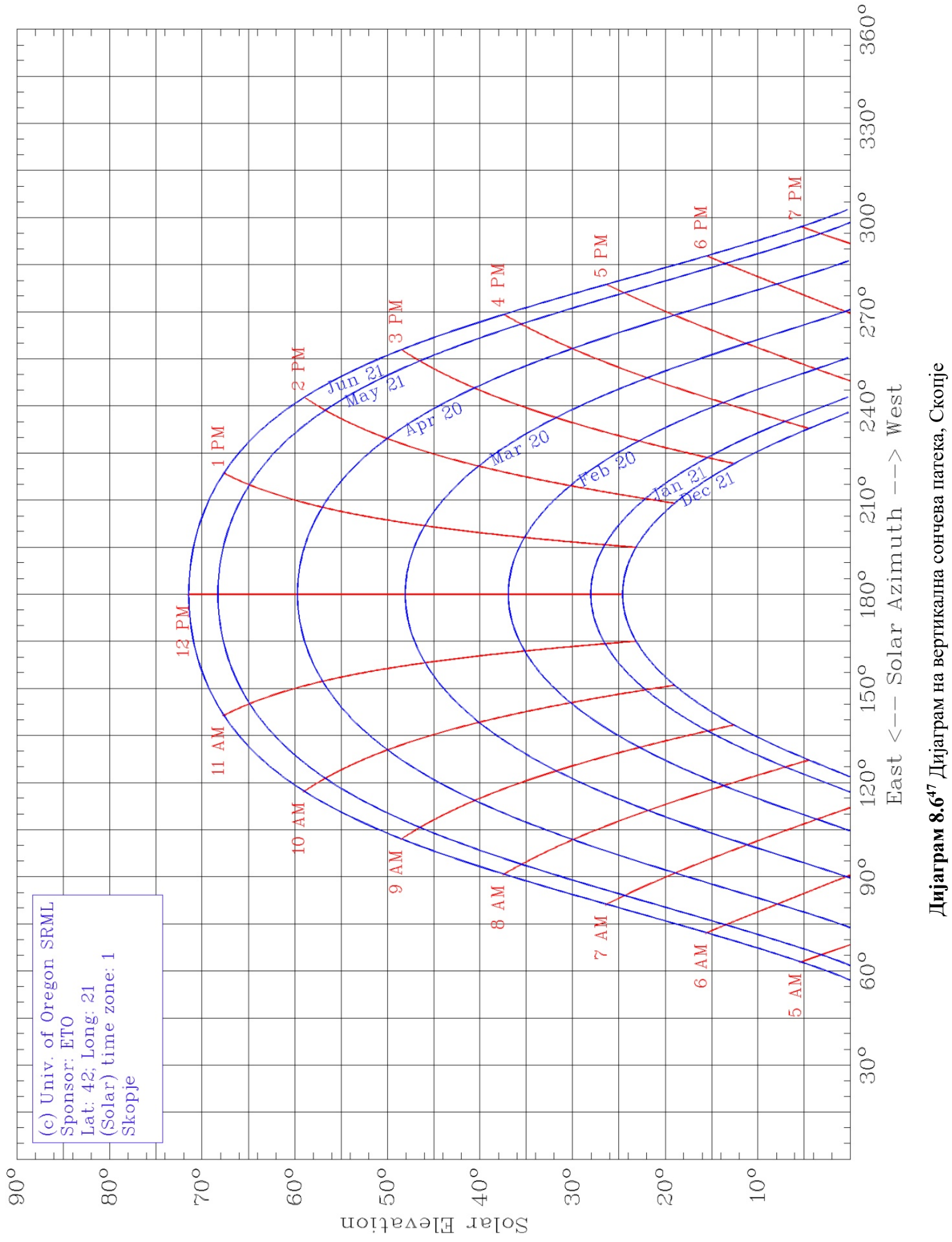

${ }^{47} \mathrm{http}$ //solardat.uoregon.edu/SunChartProgram.html 
Со цел да добиеме точен увид дали овој уред навистина функционира онака како што е предвидено, со помош на податоците од соларната геометрија моделот ќе биде ориентиран во просторот и како таков тестиран со помош на софтверот Ecotect Analysis.

3Д моделот е анализран за неколку периоди од годината како и за различни часовни периоди во ист ден. Овие анализи се прикажани на Слика 8.1, Слика 8.2, Слика 8.3, Слика 8.4 и Слика 8.5. Од нив јасно може да се видат сите промени во однос на ориентацијата на рефлектирачката параболична површина, но и дека сончевите зраци во сите позиции се идеално насочени кон зоната за готвење.

Со овие анализи докажуваме дека доколу уредот завземе соодветна позиција, истиот е правилно димензиониран и дизајниран и може успешно да одговори на својата задача.

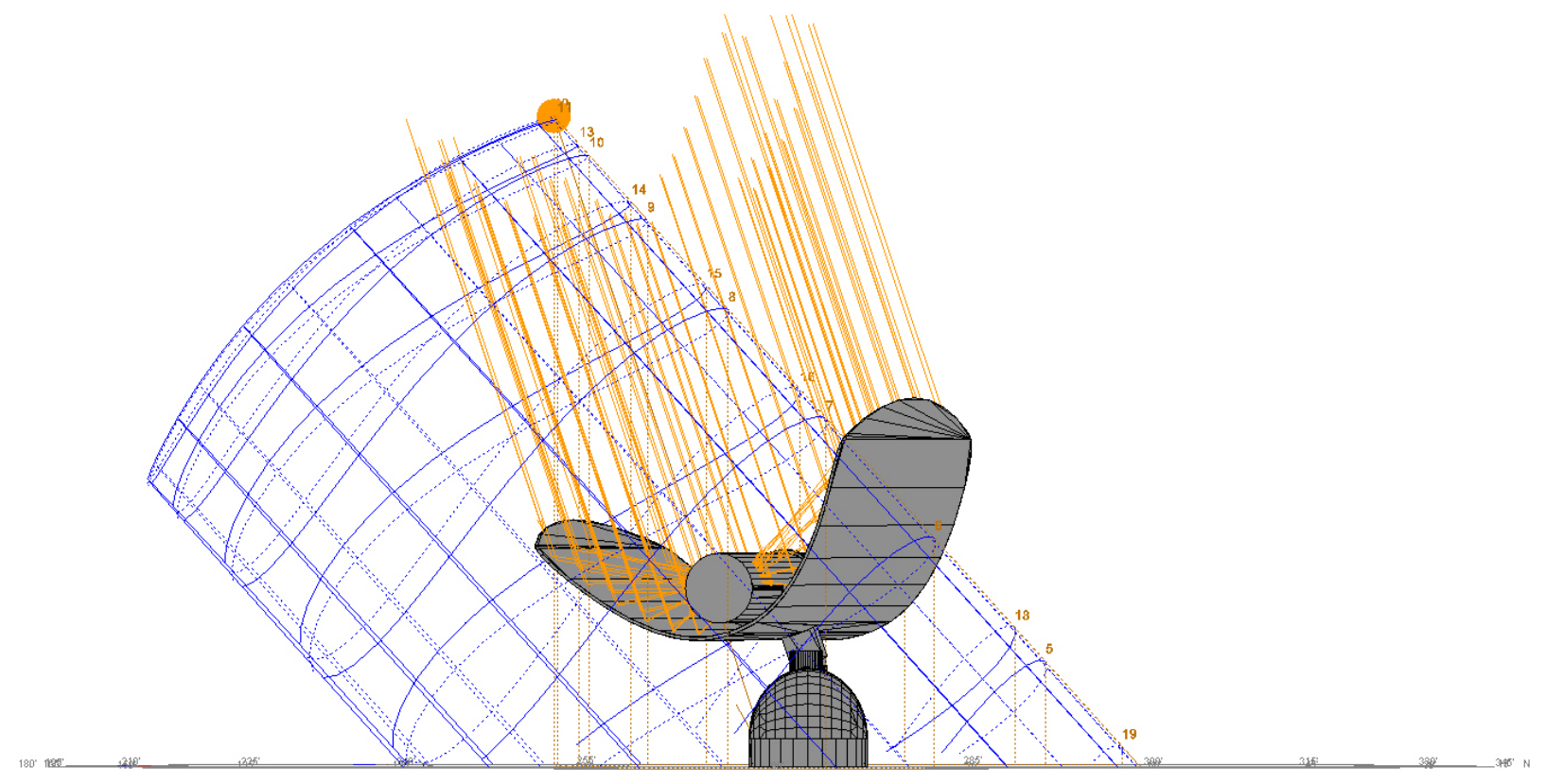

Слика 8.1 Скопје, 21 јуни, 12 часот. Агол на наклон на параболична површина 19,1; агол на ротација 15,9 


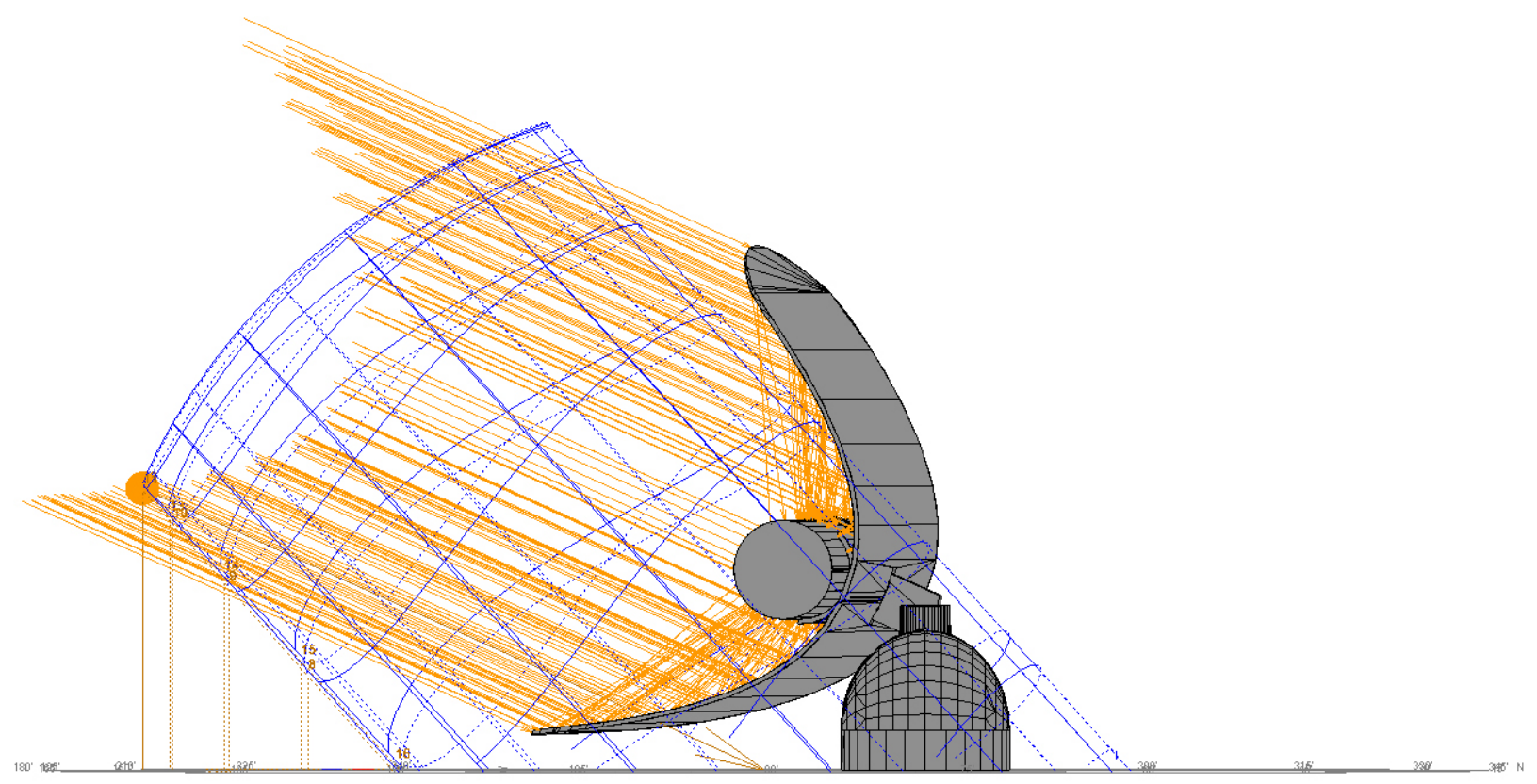

Слика 8.2 Скопје, 21 декември, 12 часот. Агол на наклон на параболична површина 65,8; агол на ротација $6,6^{\circ}$

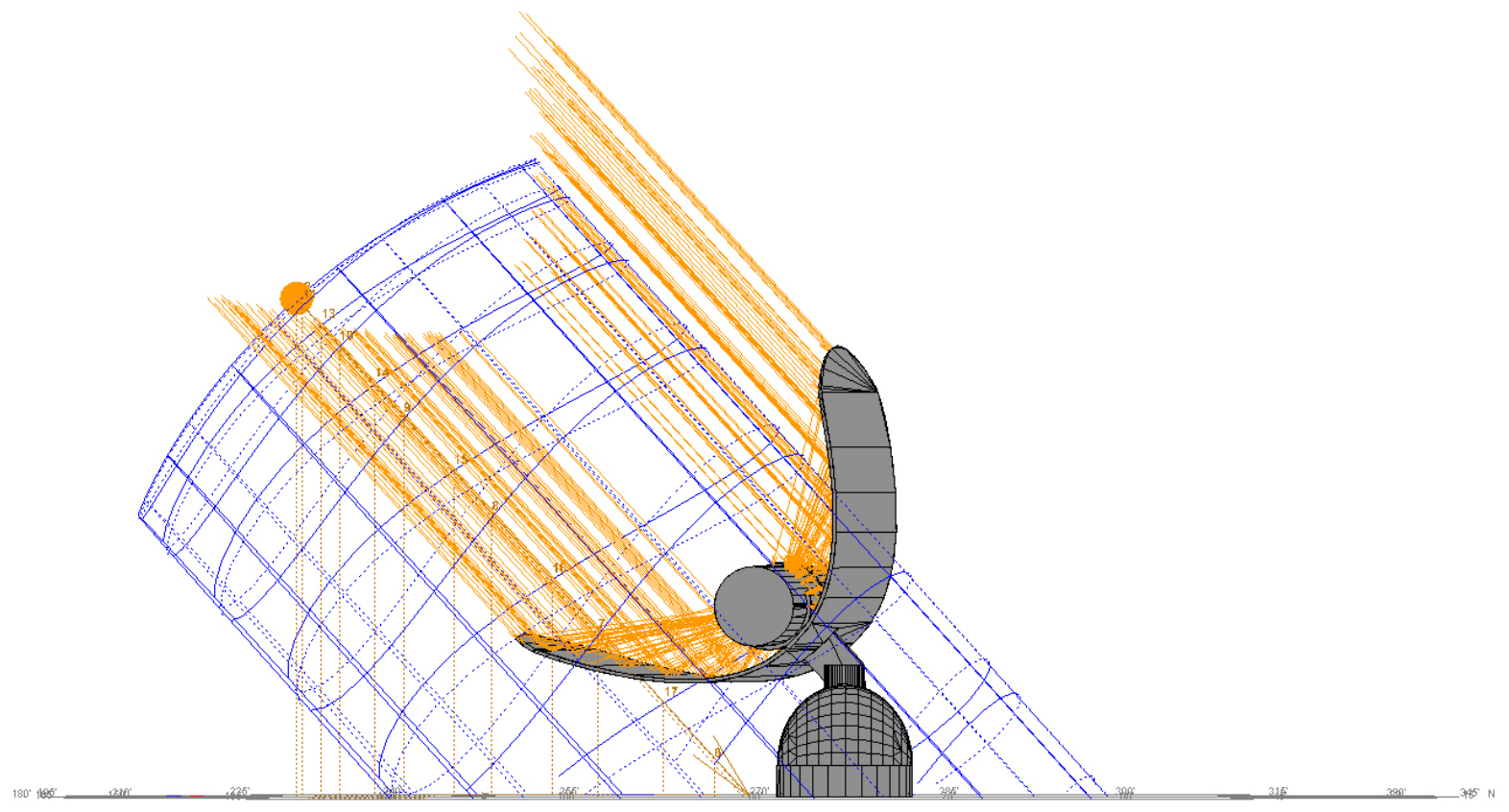

Слика 8.3 Скопје, 21 март, 12 часот. Агол на наклон на параболична површина 42,4; агол на ротација 6,2 

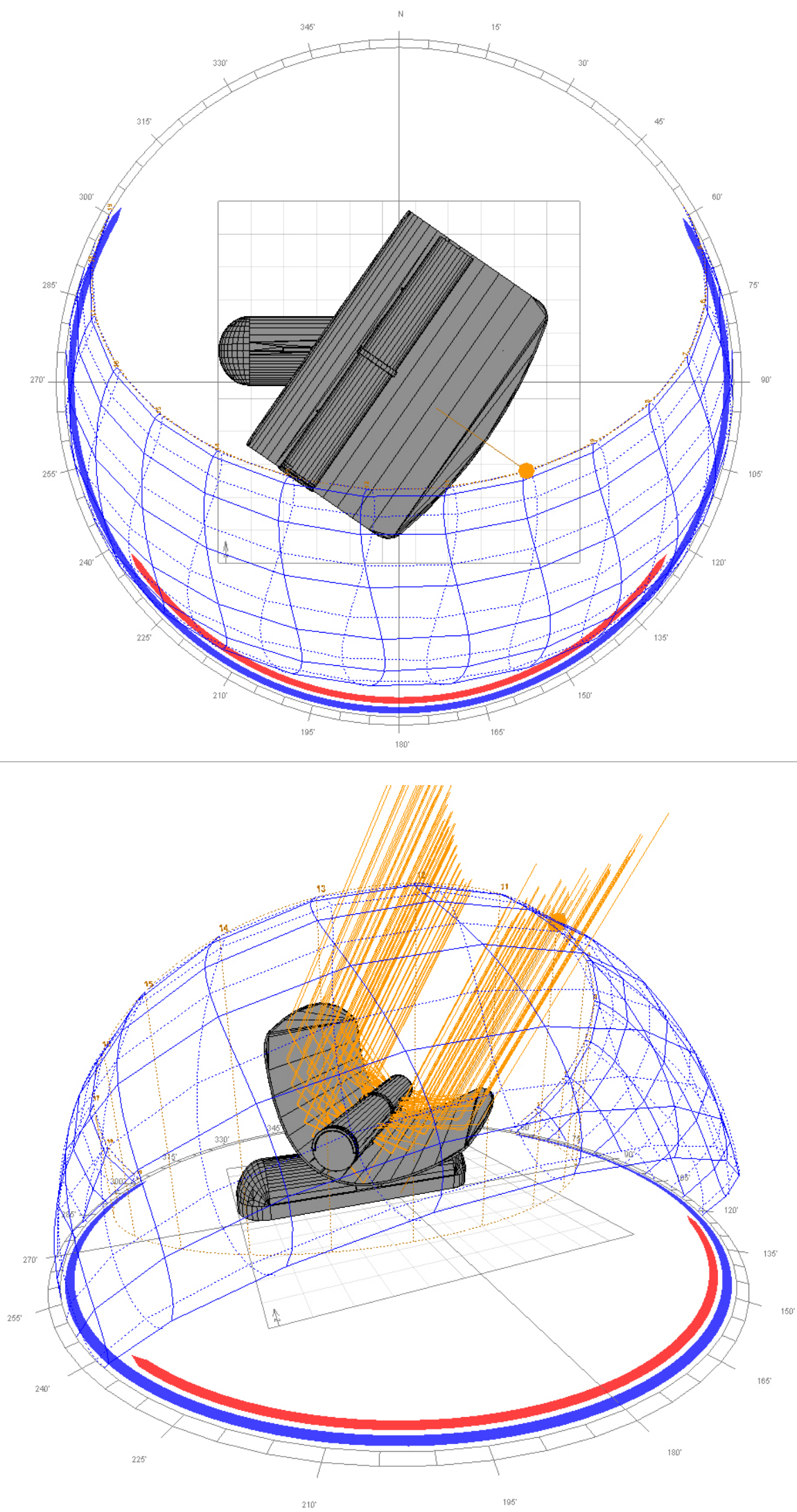

Слика 8.4 Скопје, 21 јуни, 10 часот. Агол на наклон на параболична површина 27,5; агол на ротација 55,2 

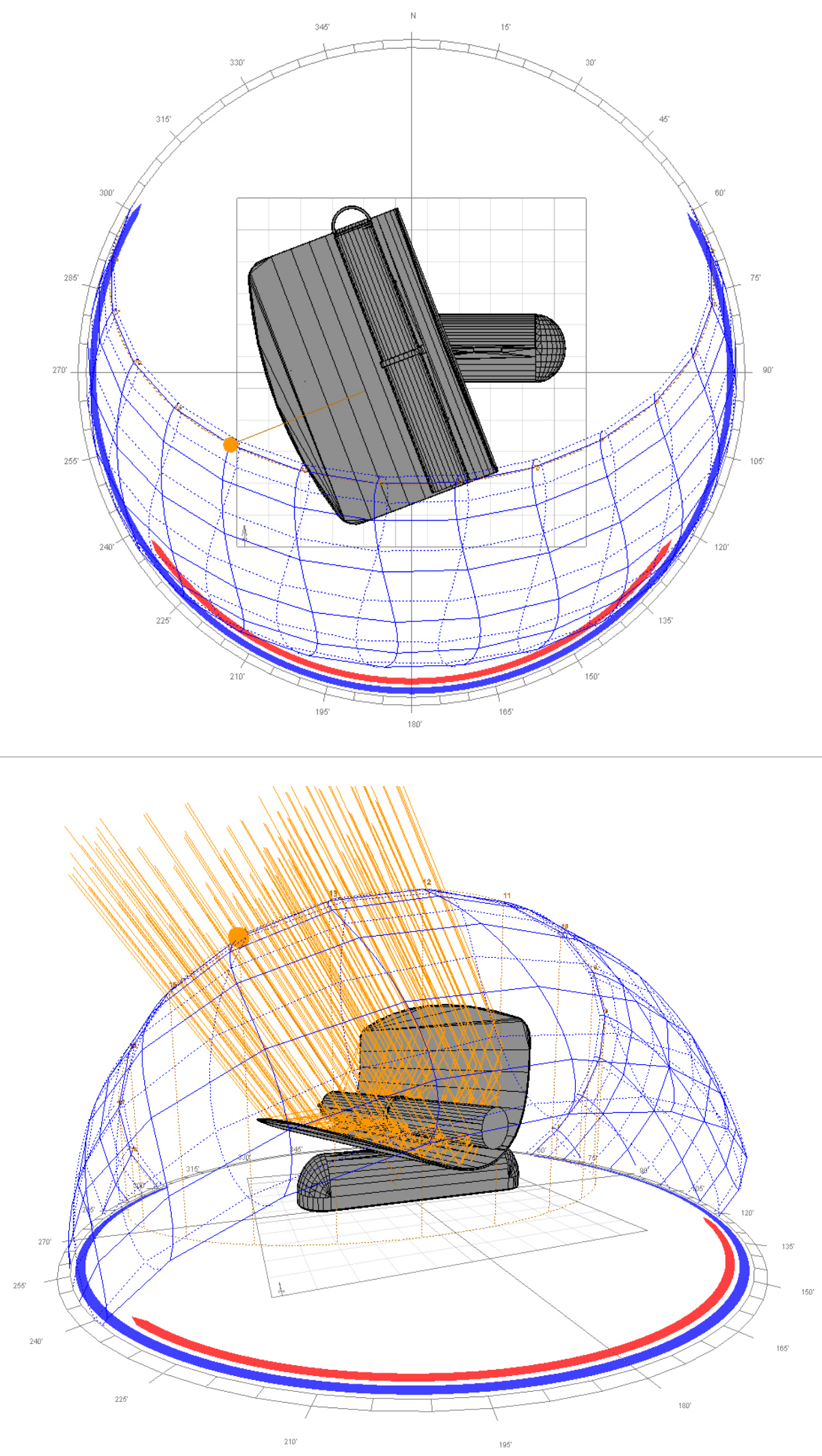

Слика 8.5 Скопје, 21 јуни, 14 часот. Агол на наклон на параболична површина 34,9; агол на ротација $-69,1^{\circ}$ 
Следната анализа има за цел го испита рефлектирањето на сончевите зраци, а со тоа и ефикасноста на уредот при услови на ист агол на паѓање на зраците, но менување на аголот на наколон на параболата. Ова е важно за да утврдиме кои отстапување на аголот во однос парабола-сончеви зраци е дозволено за уредот да продолжи да функционира ефикасно. Испитувањето беше спроведено со помош на софтвер за анализа на оптички системи и осветлување $\mathrm{APEX}^{48}$. На Слика 8.6 јасно се гледаат отстапувањата.

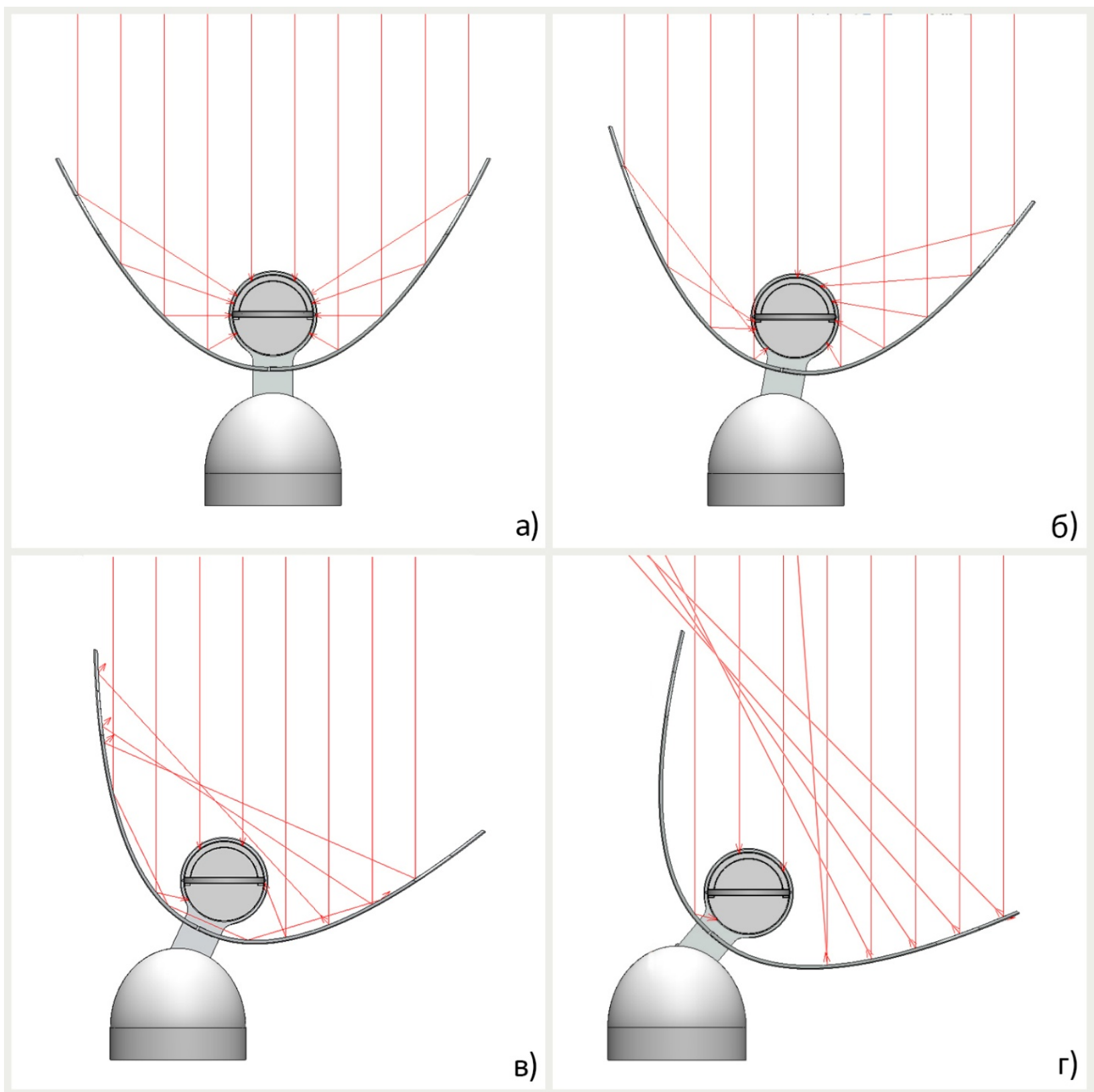

Слика 8.6 Различни степени на поставеност на наклонот на параболата при ист агол на паѓање на сончевите зраци

${ }^{48}$ http://www.breault.com/software/about-apex 
a) Идеална поставеност на наклонот на параболата. Оваа е позиција во која уредот ја добива максималната енергија од Сонцето и е најефикасен во својата функција.

б) Отстапување за $10^{\circ}$ на наколонот на параболата во однос на идеалната поставеност прикажана на Слика 8.6/a, но уредот продолжува да биде ефикасен. Рефлектираните зраци и понатаму се насочени кон просторот за готвење.

в) Отстапување на наклонот на параболатаза за $25^{\circ}$ во однос на идеалната поставеност. Веќе јасно се гледа дека еден дел од зраците не се рефлектираат кон апсорберот (цевката). Ефикасноста на уредот е доста намалена.

г) Отстапување за $40^{\circ}$ од идеалната поставеност на наклонот на параболата. Најголемиот дел од зраците се рефлектираат надвор од параболата. Уредот е неефикасен. 


\section{9. Заклучок}

Во овој магистерски труд презентиран е обид за креирање на уред, целосно независен од електричната мрежа кој ќе може термички да подготвува храна, а ќе функциноира единствено на соларна енергија. Ваквиот начин на функционирање треба да претставува алтернатива на досега применуваните традиционални методи за готвење.

Истражувањето се одвиваше во неколку фази. Најпрво беа проучени традиционалните технологии за искористување на соларна енергија, можностите кои ги нуди современата наука, како и големиот потенцијал за во иднина. Овој вид на теоретска подлога беше неопходен и исклучително важен за успешно креирање на идејните концепт решенија.

Со истражувањето на постоечките уреди во оваа областа, беа извлечени најважните принципи, кои понатаму беа применети во процесот на развој на дизајнерската идеја. Тоа се состоеше од анализата на конструкцијата, материјалите и начин на функционирање на секој од нив, кој ги покажа сите предности кои ги нуди оваа технологија, но и недостатоците кои во иднина треба да се подобрат.

Прецизно дефинирање на барањата и потребата од ваков вид производ се изврши преку анкетирање на потрошувачите. Анализата беше финализирана со примена на куќа на квалитет, при што барањата на потрошувачите беа преточени во конкретни инженерски барања.

Со примена на бионичкиот метод одгоре-надолу, беше извршено реформулирање на претходно изнесените барања и нивно дефинирање преку соодветни функции од природата. Преку истражувањето на процесите и структурите од природата, се дојде до соодветни биолошки модели кои беа применети на концепт решенијата. Понатаму, преку процесот на евалуација се одбра најсоодветниот. Уредот за подготовка на храна е компактен, независен од ел. мрежа, со голем капацитет за готвење на различни оброци истовремено, лесен и безбеден за употреба, функционален, допадлив и еколошки.

Концептот на уред за подготовка на храна, предложен како краен резултат во овој магистерски труд, треба да даде придонес кон подобрување и заштита на животната средина, како и да обезбеди еден мал вид на енергетска независност во секојдневието на 
луѓето. Ова истражување треба да биде поттик за изнаоѓање нови, иновативни решенија, каде примарна цел ќе биде искористувањето на енергијата од обновливите извори и урнек за останатите индустриски дизајнери како да постапуваат во процесот на дизајнирање во рамките на нивните дизајнерски задачи, поточно, како да трагаат кон решенија кои ќе придонесат кон заштитата на човековата околина. 
ПРИлОГ А - Приказ на резултатите од анкетниот прашалник преку графикони и табели 

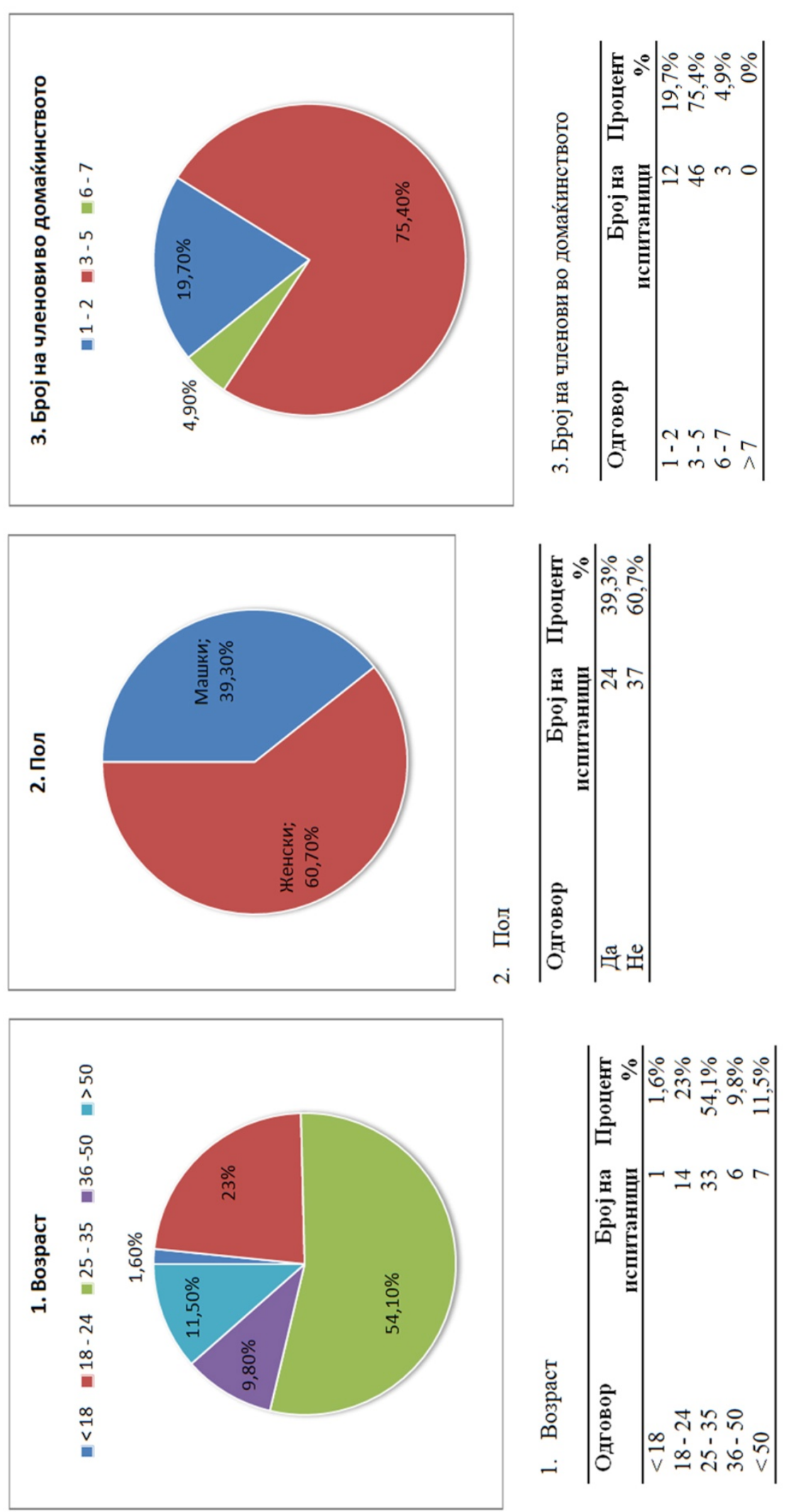

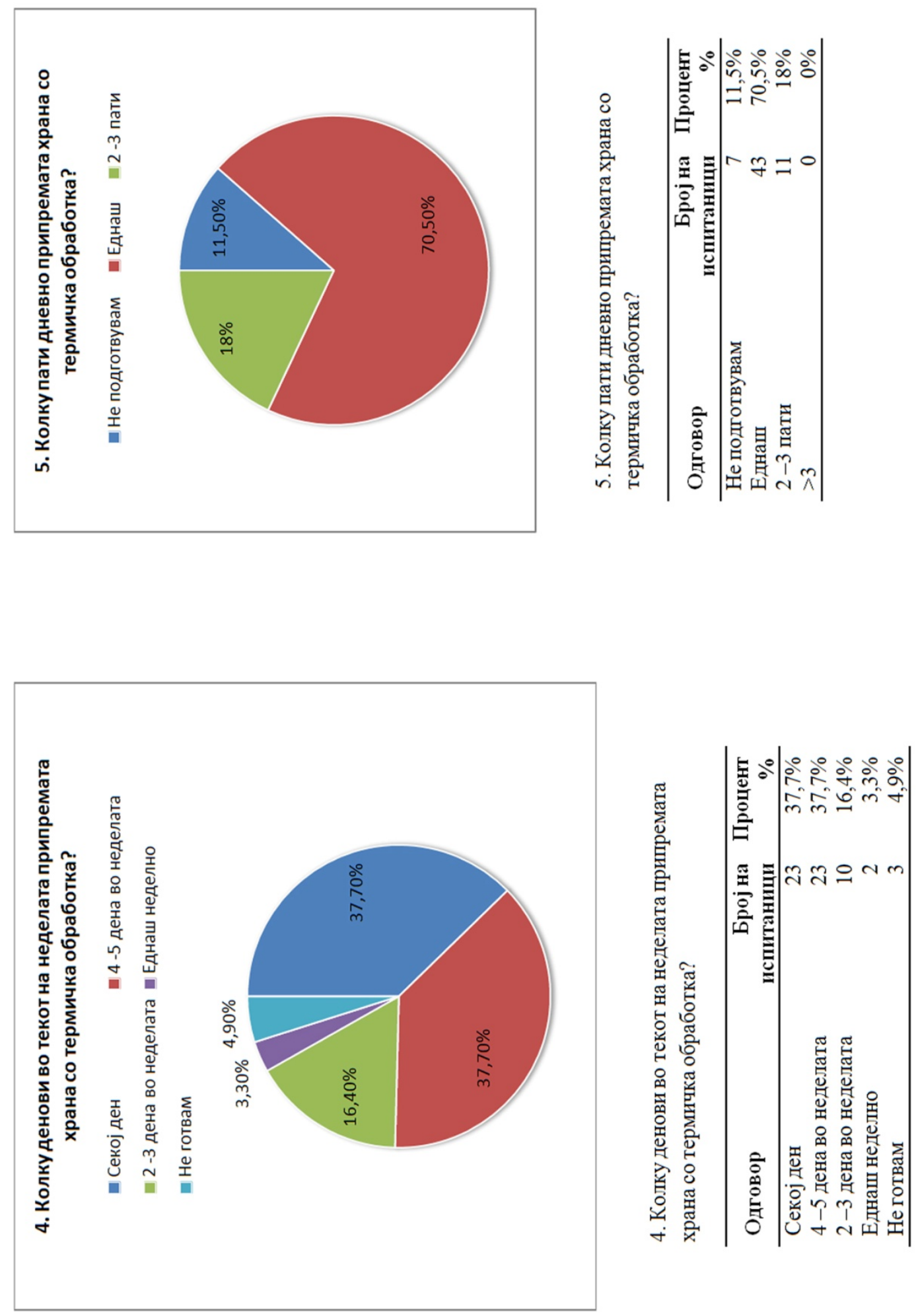

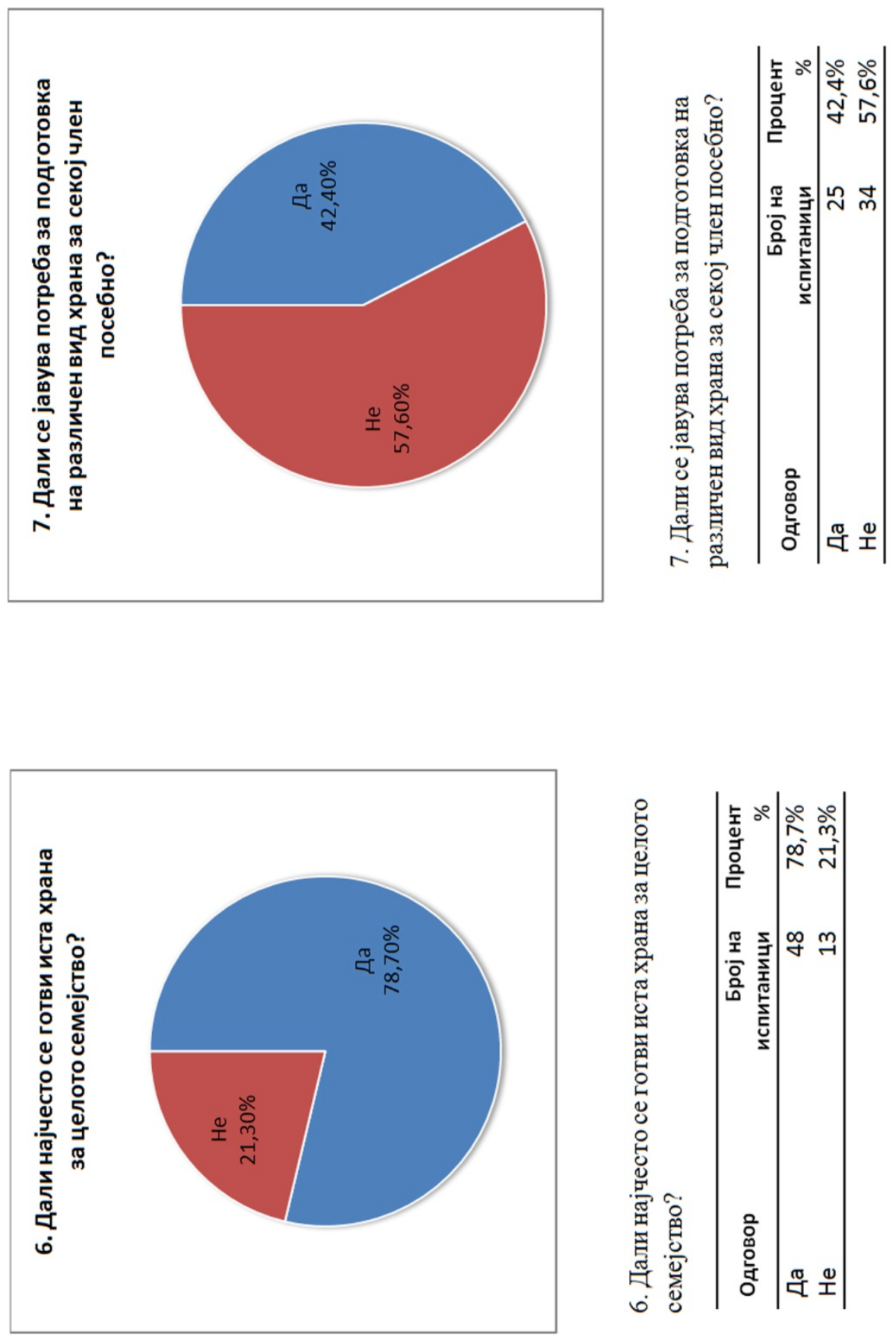

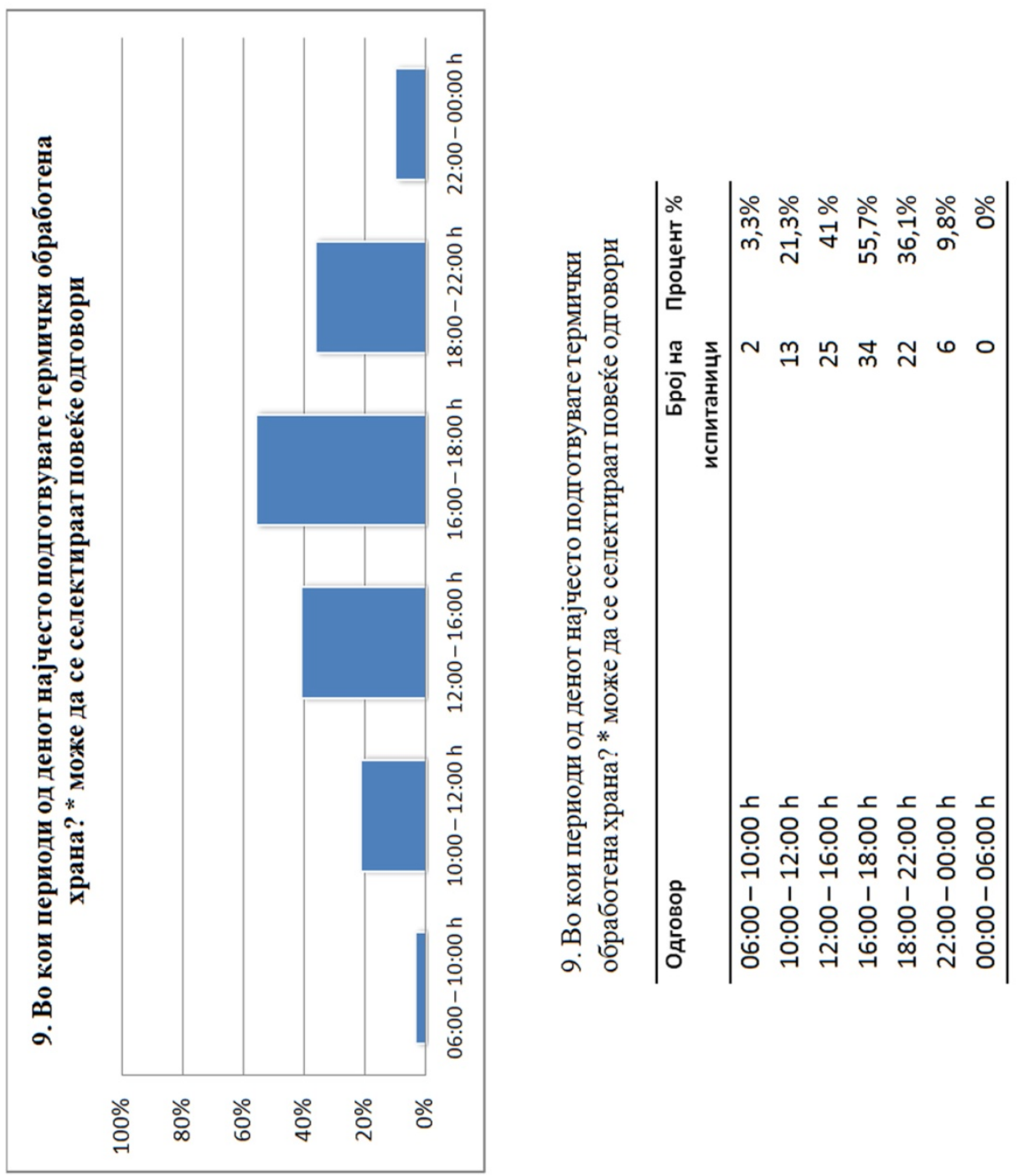

\begin{tabular}{|c|c|c|}
\hline$\varepsilon$ & ZII & әчәжdШ \\
\hline$\tau$ & $6 \mathrm{II}$ & әщәһӘШ \\
\hline I & $\varepsilon Z I$ & әчәdеg \\
\hline${ }_{\text {әнедилне }}^{d}$ & инәоџ & tug \\
\hline
\end{tabular}



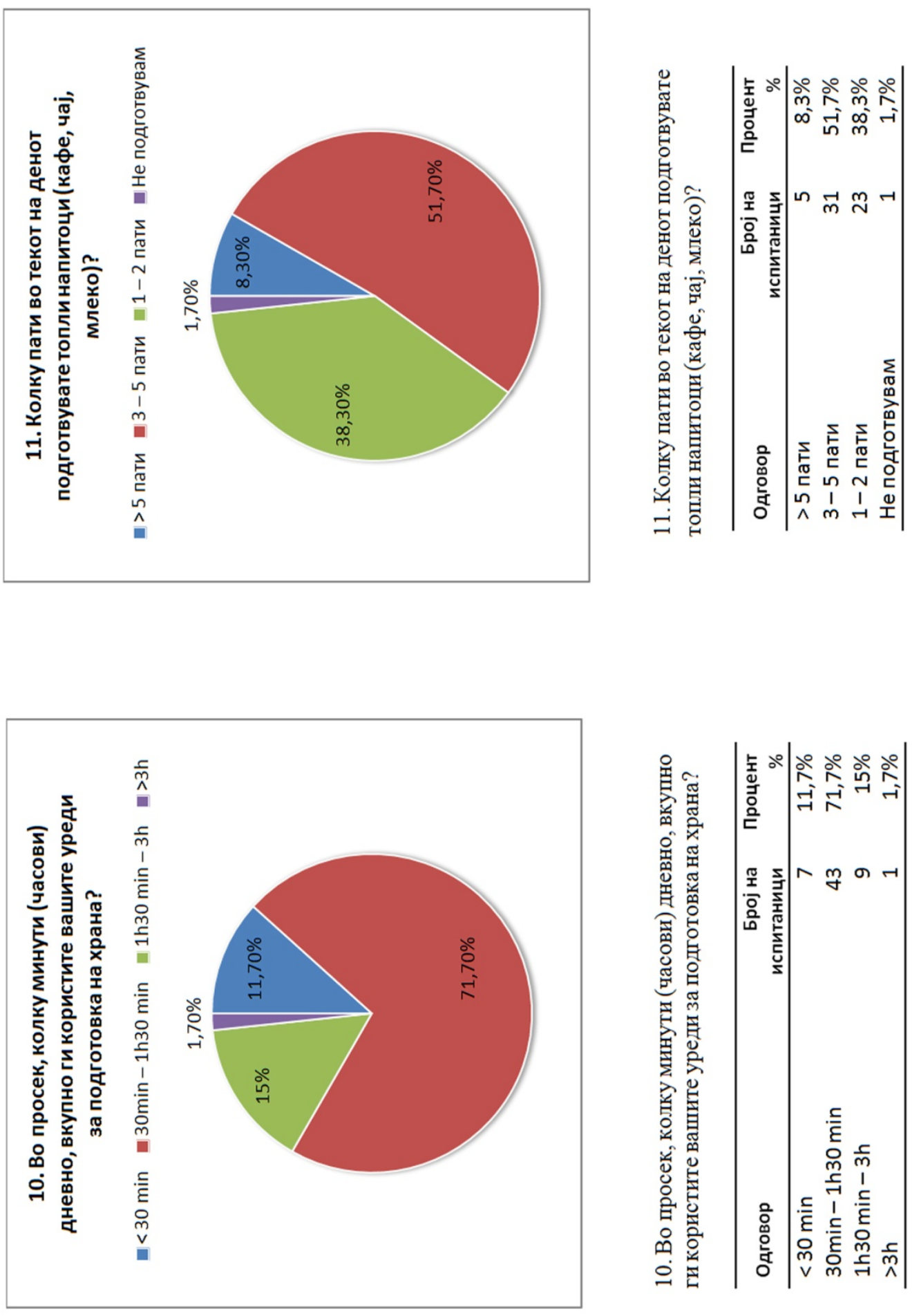

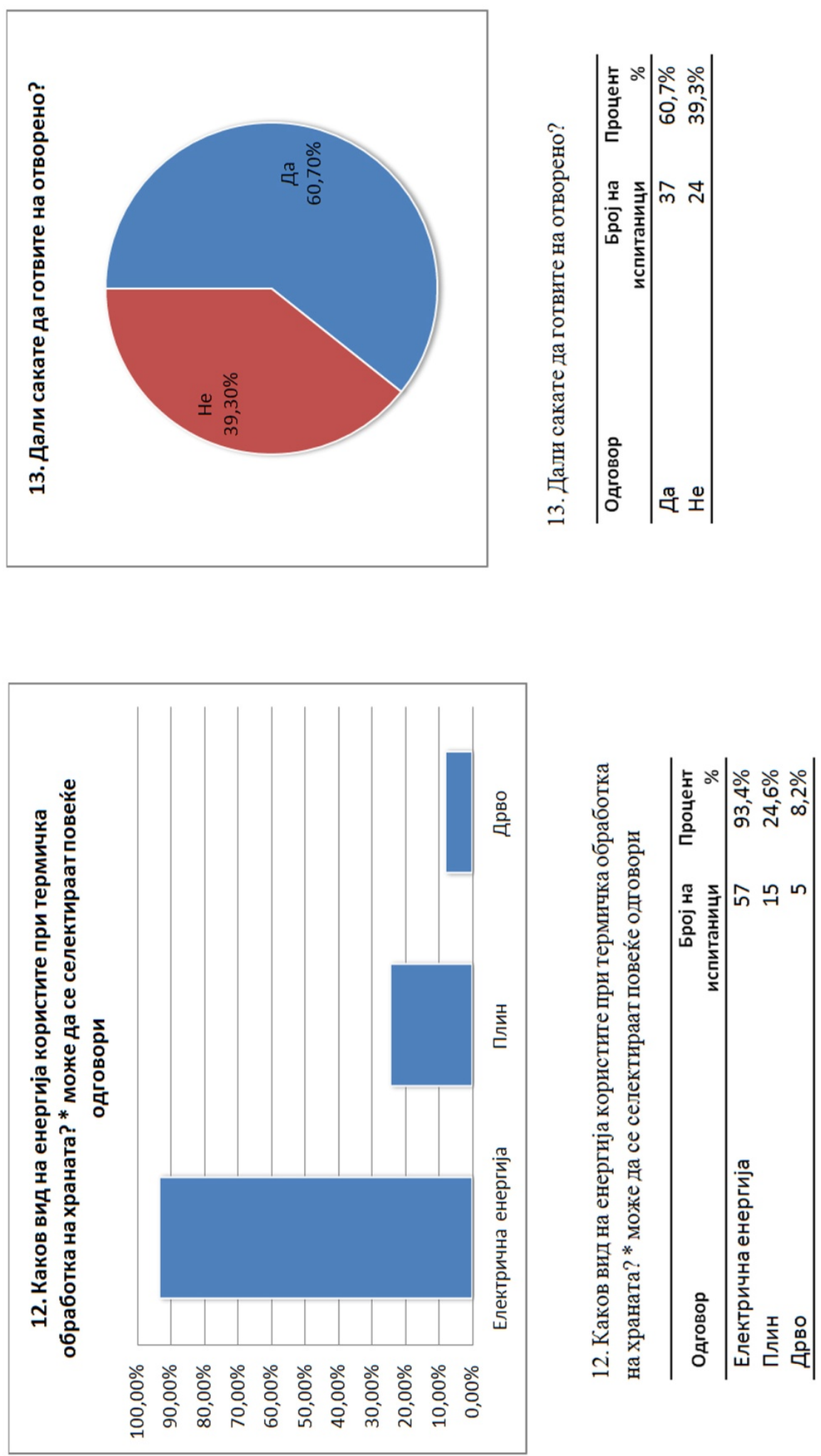

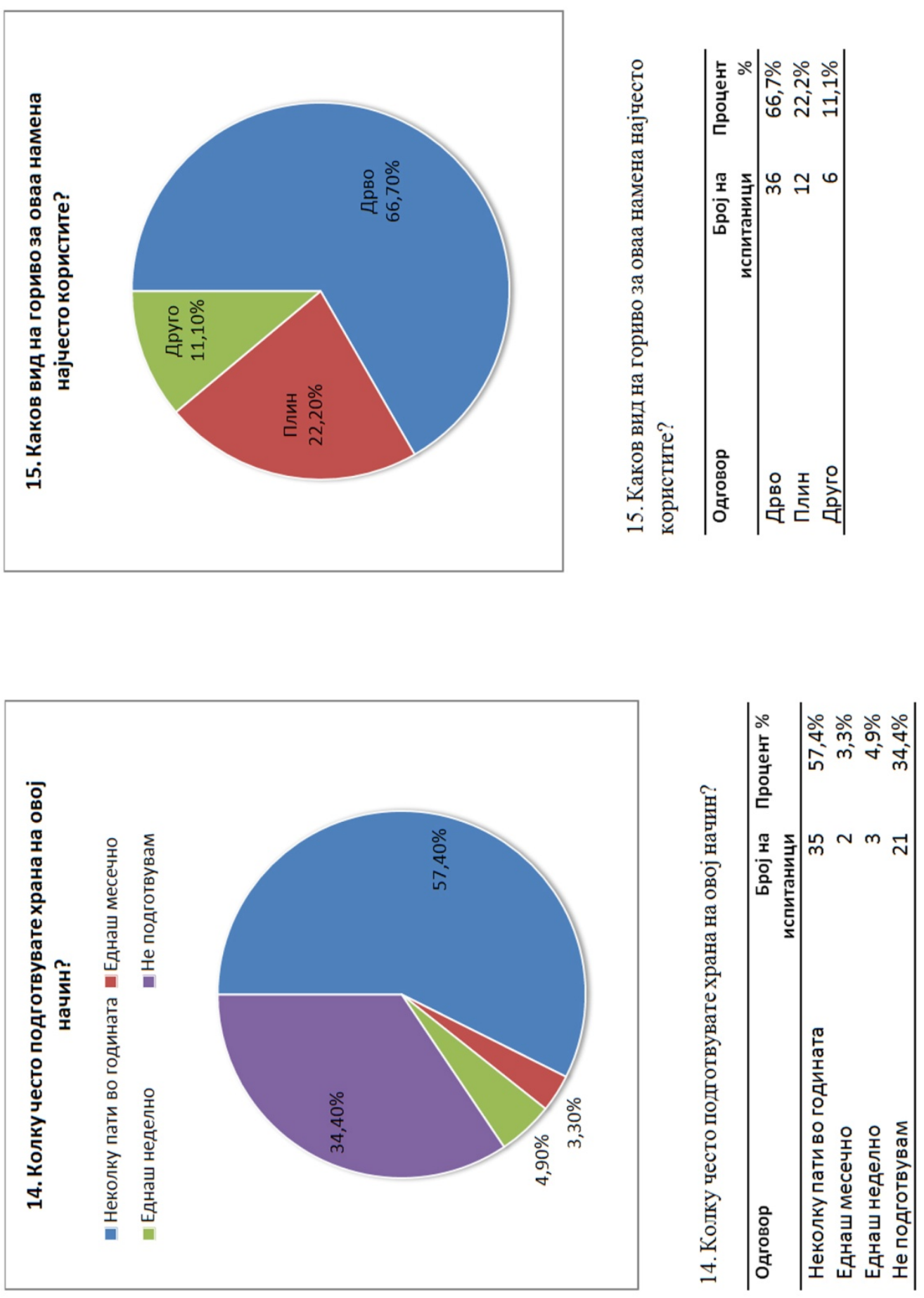

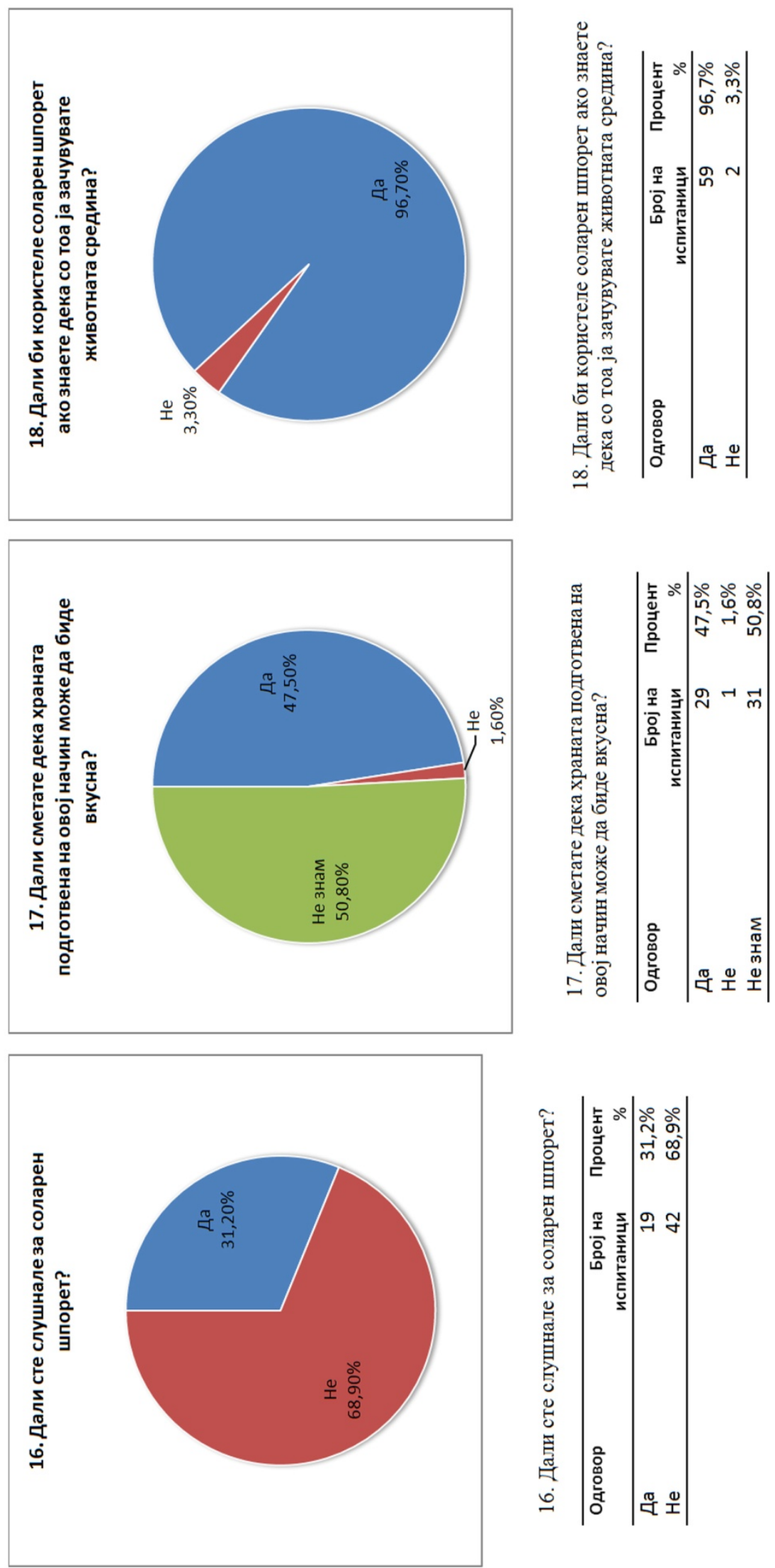
ПРИлог Б- Техничка документација 


\section{Библиографија}

\section{Користена литература}

[1] Carlos A. M. Versos, Denis A. Coelho, A Bi-Directional Method for Bionic Design with Examples

[2] CZM Kimambo, Development and performance testing of solar cookers, Department of Energy, University of Dar es Salaam

[3] Dan Halacy, Beth Halacy, Cooking with the Sun: How to Build and Use Solar Cookers

[4] Dane Dormio, Steven Jones, Evaluation of Several Original and Commonly Used Solar Cooker Designs, Solar Cookers International Network, 2002

[5] J.Harrison, Investigation of Reflective Materials for the Solar Cooker, Florida Solar Energy Center, 2001

[6] Jamshid Emami, Mahshid Tashakori, Zahra Tashakorina, Bionic Design in Industrial Desing, Education at University of Tehran

[7] Ken Butti, John Perlin, A Golden Thread: 2500 Years of Solar Architecture and Technology, 1980

[8] Lorraine Anderson, Rick Palkovic, Cooking with Sunshine: The Complete Guide to Solar Cuisine with 150 Easy Sun-Cooked Recipes, 2006

[9] Neurohr, R., Dragomirescu, C., Bionics in Engineering-Defining new Goals in Engineering, Education at "Polytehnica" University of Bucharest

[10] Norbert Lechner, Heating, Cooling, Lighting: Sustainable Design Methods for Architects, $3^{\text {rd }}$ Edition, 2009

[11] Petri Konttinen, Thermodynamic Review of Solar Box Cookers, Helsinki University of Technology, 1995

[12] Solar Cookers International, Solar Cookers: How to make, use and enjoy, $10^{\text {th }}$ Edition, 2004

[13] Vaughn Bradshaw, The Building Environment: Active and Passive Control Systems, 2006 
[14] Е.Фиданчевска, В. Сребренкоска, Инженерство на материјали, Темпус проект Tempus 158989-Tempus-1-2009-1-BE-Tempus-JPHES "Creation of university-enterprise cooperation networks for education on sustainable technologies

[15] Петар Намичев, Влијанијата на економската криза врз современиот дизајн, 2012

[16] Славе Арменски, Сончева енергија - термичка трансформаиија, 2012

\section{Користени интернет страни}

[1] http://www.ap.osu.edu/FileStore/PDFs/EM What size generator do I need.pdf

[2] http://www.asknature.org

[3] http://www.ea.gov.mk/index.php?option=com_content\&view=article\&id=53

[4] http://www.elem.com.mk/calculator/index_en.html

[5] http://www.fenixintl.com/product/readyset-solar-kit/

[6] http://www.goenerplex.com/products/all-products/packr

[7] http://www.gosunstove.com

[8] http://www.idcook.com

[9] http://www.lightoven.de

[10] http://www.solarcooking.wikia.com/wiki/BCK_Solar_Cooker

[11] http://solardat.uoregon.edu/SunChartProgram.htm

[12] http://www.solarimpulse.com

[13] http://www.stat.gov.mk/PrikaziSoopstenie.aspx?rbrtxt=62

[14] http://www.sunpartnertechnologies.com/

[15] https://www.solarcookers.org 